\title{
História do pensamento geográfico e epistemologia em geografia
}

\author{
Paulo R. Teixeira de Godoy \\ (org.)
}

GODOY, PRT., org. História do pensamento geográfico e epistemologia em Geografia [online]. São Paulo: Editora UNESP; São Paulo: Cultura Acadêmica, 2010. 289 p. ISBN 978-85-7983-127-0. Available from SciELO Books $<$ http://books.scielo.org $>$.

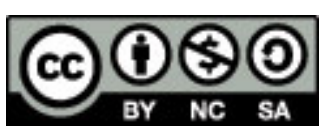

All the contents of this work, except where otherwise noted, is licensed under a Creative Commons Attribution-Non Commercial-ShareAlike 3.0 Unported.

Todo o conteúdo deste trabalho, exceto quando houver ressalva, é publicado sob a licença Creative Commons Atribuição Uso Não Comercial - Partilha nos Mesmos Termos 3.0 Não adaptada.

Todo el contenido de esta obra, excepto donde se indique lo contrario, está bajo licencia de la licencia Creative Commons Reconocimento-NoComercial-CompartirIgual 3.0 Unported. 


\section{HistóRIa \\ DO PENSAMENTO GEOGRÁFICO E EPISTEMOLOGIA EM Geografia}


CONSELHO EDITORIAL ACADÊMICO

Responsável pela publicação desta obra

Antonio Carlos Tavares

Auro Aparecido Mendes

Darlene Aparecida de Oliveira Ferreira

Fadel David Antonio Filho

Maria Isabel Castreghini de Freitas

Sandra Elisa Contri Pitton 


\title{
PAULO R. TEIXEIRA DE GODOY
}

(Org.)

\author{
História \\ DO PENSAMENTO \\ GEOGRÁFICO \\ E EPISTEMOLOGIA \\ EM GEOGRAFIA
}

CULTURA

$\frac{\text { ACADÊMICAs }}{\varepsilon d i t o n a}$ 
(C) 2010 Editora UNESP

\section{Cultura Acadêmica}

Praça da Sé, 108

01001-900 - São Paulo - SP

Tel.: (0xx11) 3242-7171

Fax: (0xx11) 3242-7172

www.editoraunesp.com.br

feu@editora.unesp.br

CIP - Brasil. Catalogação na fonte

Sindicato Nacional dos Editores de Livros, RJ

H578

História do pensamento geográfico e epistemologia em Geografia /

Paulo R. Teixeira de Godoy (org.). - São Paulo : Cultura Acadêmica, 2010.

il.

Inclui bibliografia

ISBN 978-85-7983-127-0

1. Geografia - Filosofia. 2. Geografia - História. 3. Geografia - Metodologia. I. Godoy, Paulo R. Teixeira de.

10-0122.

CDD: 910.01

CDU: 910.1

Este livro é publicado pelo Programa de Publicações Digitais da Pró-Reitoria de Pós-Graduação da Universidade Estadual Paulista "Júlio de Mesquita Filho" (UNESP)

Editora afiliada:

Exण

Asociación de Editoriales Universitarias

atina y el Caribe
Associação Brasileira de 


\section{SUMÁRIO}

Apresentação 7

\section{Parte I}

1 Fundamentos históricos da geografia: contribuições do pensamento filosófico na Grécia antiga 11

Agostinho Paula Brito Cavalcanti Adler Guilherme Viadana

2 Alexander Von Humboldt: viajante naturalista e entusiasta da harmonia da natureza 35

Danilo Piccoli Neto

Flamarion Dutra Alves

3 O espaço em Kant e suas contribuições na definição do conceito de região 57

Juliana Emy Carvalho Tanaka;

4 A geografia escolar no Brasil, de 1546 até a década de 196071

Thiago Tavares de Souza

João Pedro Pezzato 


\section{Parte II}

5 Dos modelos à explicação: a Nova Geografia em David Harvey 91

Danilo Piccoli Neto

6 Quinze bons argumentos contra a geografia teorética; quatorze contra-argumentos melhores ainda (ou quando o quantitativo nada quer dizer) 111

Dante F. C. Reis Junior

7 Algumas considerações para uma revisão crítica da História do Pensamento Geográfico 145

Paulo R. Teixeira de Godoy

8 As possibilidades de aplicação do método de análise regressivo-progressivo de Henri Lefèbvre na geografia urbana 157

Silvia Aparecida Guarnieri Ortigoza

\section{Parte III}

9 Riqueza e miséria do ciclo da borracha na Amazônia brasileira: um olhar geográfico por intermédio de Euclides da Cunha 187

Fadel David Antonio Filho

10 Discutindo categorias e conceitos: uma contribuição geográfica dentro das análises da relação rural-urbano

Adriano Corrêa Maia

Darlene Aparecida de Oliveira Ferreira

11 As bases teóricas da geografia agrária brasileira: o pensamento de Pierre Monbeig e Leo Waibel 231 Flamarion Dutra Alves

12 As duas novas leituras do Homem-caranguejo de Josué de Castro 259 Bruno Picchi

13 A teoria geográfica nos estudos do turismo: elementos teórico-metodológicos 277

Elias Júnior Câmara Gomes Sales 


\section{ApresentaÇÃo}

A História do Pensamento Geográfico consiste em um campo de discussões teóricas, filosóficas, institucionais, epistemológicas e metodológicas. Embora sua relevância seja reconhecida entre os geógrafos, existem poucos estudos dedicados aos problemas enfrentados pela geografia em sua trajetória científica, histórica e social.

O objetivo deste livro não é suprir as deficiências ou as lacunas da História do Pensamento Geográfico e, tampouco, adotar o escrúpulo historicista de compreensão de uma história petrificada em narrativas e pontos de vista acerca de problemas científicos que interessam a poucos. Nesse sentido, não se trata, fundamentalmente, da História do Pensamento Geográfico como tradicionalmente se concebe o conjunto de temas relacionados ao desenvolvimento científico da geografia. Se essa fosse a sua finalidade, sua deficiência seria manifesta e o desequilíbrio entre as partes retiraria todo o seu sentido. O seu propósito é o de reunir as contribuições de docentes e pósgraduandos em geografia em torno de dois grandes eixos temáticos: História do Pensamento Geográfico e epistemologia em geografia.

A organização dos capítulos se orientou por temáticas que trataram, na Primeira Parte, dos fundamentos históricos da geografia, centrados no pensamento filosófico sobre a relação Homem-Natureza; das contribuições de Humboldt como naturalista e entusiasta da 
natureza; da concepção de espaço, segundo Kant, e suas influências na geografia regional; e da história do ensino de geografia no Brasil.

Em seguida, na Segunda Parte, para introduzir os temas de cunho teórico-metodológico, foram apresentados, inicialmente, a análise das contribuições metodológicas de David Harvey em Explanation in Geography (1969); uma reflexão sobre os argumentos teóricos e metodológicos da geografia teorética; uma proposição metodológica a partir do pensamento de Henri Lefèbvre; e, finalmente, a apresentação de elementos para uma discussão sobre a História do Pensamento Geográfico.

$\mathrm{Na}$ Terceira Parte do livro foram reunidos os capítulos que tratam de temas mais específicos, tais como: a relação entre a geografia e a literatura, por meio da obra de Euclides da Cunha; a releitura do pensamento de Josué de Castro; os problemas conceituais da análise da relação rural-urbana; considerações acerca das bases teóricas da geografia agrária brasileira a partir das obras de Pierre Monbeig e Leo Waibel; e, finalmente, as relações entre geografia e turismo a partir de uma reflexão teórica e conceitual.

O livro possui, em certo sentido, um caráter didático que atende não somente estudantes universitários e professores de geografia, mas também a interesses de outras áreas do conhecimento, como a história, a sociologia e a antropologia. Com efeito, o livro não tem como tarefa nos munir de convicções novas, mas fazer-nos colocar em questão o modo como são abordados e discutidos os problemas da história da geografia e de sua construção como ciência. 
PARTe I 



\title{
1
FUNDAMENTOS HISTÓRICOS DA GEOGRAFIA: CONTRIBUIÇÕES DO PENSAMENTO FILOSÓFICO NA GRÉCIA ANTIGA
}

\author{
Agostinho Paula Brito Cavalcanti* \\ Adler Guilherme Viadana**
}

\section{Introdução}

Os fundamentos históricos da ciência geográfica reportam-se à Grécia antiga, tida como a primeira cultura conhecida a explorar ativamente a geografia como ciência e filosofia.

A filosofia constrói o embasamento conceitual das atividades humanas a partir dos fundamentos do pensamento, no plano das ideias e do enquadramento abstrato e geral do conhecimento, incluindo as ciências, artes e técnicas.

As teorias ajustam as distintas e específicas áreas científicas, por meio da descoberta ou investigações de novos setores e novos problemas no âmbito de cada ciência em particular.

As metodologias desenvolvem e experimentam técnicas inovadoras permitindo a obtenção de respostas mais eficientes para os problemas, mediante conceitos científicos fornecidos pelas teorias.

Baseada em princípios estabelecidos pelas fundamentações teóricas, com aplicação por meio de métodos adequados, a ciência geográfica procura soluções para os problemas expostos pela sociedade.

* Professor doutor associado do Departamento de Geografia, Universidade Federal do Piauí (UFPI), campus da Ininga/Teresina (PI).

** Professor adjunto do Departamento de Geografia, Unesp - Rio Claro (SP). 
As viagens dos exploradores espalharam pela Europa o interesse pela geografia, e a cartografia elaborada, à medida que se descobriam novas terras, incluía técnicas inovadoras.

Durante a Idade Média, foram aprofundados e mantiveram-se os antigos conhecimentos gregos, e no período da Renascença e ao longo dos séculos XVI e XVII, as viagens de exploração reavivaram o desejo de bases teóricas mais sólidas e de informações mais detalhadas.

A partir do século XVIII, a geografia foi sendo reconhecida como disciplina científica e, ao longo do século passado, a quantidade de conhecimento e o número de instrumental técnico tiveram um significativo aumento, persistindo até os dias atuais.

$\mathrm{Na}$ fundamentação histórica da geografia, optou-se pelos principais precursores, de acordo com a relevância de suas obras ou mesmo pelas conceituações teóricas e metodológicas emanadas desses trabalhos, que inclui os pensadores gregos, os sete sábios da Grécia antiga, os filósofos pré-socráticos (naturalistas) com a descrição das escolas Jônica; Itálica; Eleata e da Pluralidade e seus constituintes e as contribuições do pensamento filosófico ao estudo da natureza.

\section{Métodos}

Os métodos de coleta de dados definidos constaram de pesquisa bibliográfica visando à fundamentação teórica e metodológica com a obtenção de informações sobre o tema pesquisado e da interpretação e análise dos fundamentos históricos da geografia com as contribuições do pensamento filosófico na Grécia antiga, levantando-se o acervo bibliográfico e cartográfico disponível, permitindo a compreensão do significado da Filosofia para a ciência geográfica.

\section{Fundamentos filosóficos e precursores na Grécia antiga}

Considera-se a Grécia antiga como precursora do embasamento cultural da civilização ocidental, com significativas influências em 
filosofia, política, linguagem, educação, arte, tecnologia, arquitetura e ciências, pelas formas de conhecimento, modos de reflexão ou teorias da realidade.

A Grécia antiga pode ser classificada em dois períodos:

(i) Cosmológico, com predominância de explicação mitológica do universo e da origem das principais significações da realidade. Esse saber mitológico procurava uma explicação para a época e momento históricos, das principais questões da existência humana, tanto na natureza (buscando o conhecimento do seu princípio material) como na sociedade (relações e modos de vida dos homens);

(ii) Antropológico, em que o discurso cosmológico e materialista passa a dar lugar a um discurso moral e político, criando-se nesse período uma nova temática: o homem. A filosofia muda de espaço geográfico, com a criação das pólis (das colônias para o centro cultural), acarretando a variação do objeto de pesquisa: da natureza para o homem.

À filosofia compete explicar a realidade, dividida no domínio da natureza, do pensamento e da criação humana. A partir dessa divisão foram surgindo as diversas ciências, repartindo o saber total da filosofia. Sobre a filosofia e as ciências, Durant (1956) indaga por que as ciências, filhas da filosolfia, depois de repartirem entre si a herança filosófica, lhe voltam as costas, como as filhas do rei Lear, depois de dividido o seu reino?

Nesse momento histórico na Grécia, havia um esforço intelectual voltado para a compreensão do mundo, do universo e da realidade, ou como era conhecido à época, o cosmos. Para os gregos, o cosmos era uma totalidade organizada racionalmente, que só poderia ser descrito pela razão, levando a visualização de uma ordem, uma unidade e uma harmonia, onde coexistem uma multiplicidade caótica das coisas e acontecimentos.

Por meio de sua mitologia os gregos consideravam os elementos da natureza (Sol, Terra, Céu, oceanos, montanhas etc.) como forças autônomas tidas como deuses, constituídos na fonte e na essência 
de todas as coisas do universo e elevados pela fantasia a seres ativos, móveis, conscientes e dotados de sentimentos, vontades e desejos.

Nesse sentido, Grimal (1954) considera que o mito atrai em torno de si toda a parcela do irracional existente no pensamento humano; por sua própria natureza, é aparentado à arte, em todas as suas criações. Sua força de mensagem reside na capacidade de sensibilizar as estruturas profundas e inconscientes do psiquismo humano.

A análise lógica na filosofia defende uma postura científica, renunciando a toda investigação de cunho religioso e valorizando os métodos racionais como instrumento na busca da verdade. Conforme Russel (1982, v.3, p.389) "A Filosofia, durante toda a sua história, tem consistido de duas partes misturadas inarmonicamente; de um lado, uma teoria sobre a natureza do mundo; de outro, uma doutrina ética ou política quanto à melhor maneira de se viver".

Os gregos intitulavam suas obras de Sobre a Natureza (Peri physeos) ao referirem-se aos aspectos da ciência positiva e da filosofia. A física era designada como um nome adequado para a ciência da natureza, significando atualmente como a ciência positiva dos fenômenos naturais e o setor filosófico, passando a ter uma nova designação: a filosofia natural ou da natureza.

Até o desenvolvimento da ciência moderna, a filosofia natural foi a expressão introduzida na Grécia antiga para indicar o estudo objetivo da natureza e do universo físico ou a que trata do conhecimento das primeiras causas e dos princípios do mundo material; ou ainda, o estudo racional da natureza do ponto de vista de sua especificidade substancial e de suas propriedades, usando o pensamento e o raciocínio, sendo utilizada pelos pensadores, destacando-se pelas especulações teóricas e investigações práticas.

Diferentemente da ciência, a filosofia natural não procura descrever os fenômenos da natureza, mas chegar à essência dos entes que possuem corpo, partindo do ente sensível das coisas materiais existentes para posteriormente alcançar o conceito de ser, ao conhecimento do homem e à demonstração racional da existência de Deus. Russel (1954) acredita que a filosofia é uma atividade contínua e não algo em que possamos atingir, de uma vez por todas, uma perfeição final. 
Na origem desse conhecimento está a necessidade de perguntar, de indagar, o que são as coisas e o que é o homem. A pergunta supõe, consequentemente, a ignorância em relação ao que se pretende ou se precisa saber, pressupondo também, e ao mesmo tempo, a consciência da ignorância e o conhecimento daquilo que se desconhece e se precisa conhecer. Não sei e sei que não sei, e essa consciência da ignorância, a ciência da insciência, é o que me permite perguntar, quer a pergunta se dirija à natureza, quer se enderece aos outros homens (Corbisier, 1986).

Inserida no desenvolvimento histórico da geografia, desde épocas remotas até os dias atuais, aparece a cartografia, acompanhando o próprio progresso da civilização, podendo-se afirmar que, das demais formas de comunicação gráfica, a mais antiga da humanidade é o mapa, confirmada por evidências históricas, arqueológicas e etnológicas.

A intensificação das rotas pelo Mediterrâneo facilitou o intercâmbio cultural e as ideias entre o mundo grego e oriental. Segundo Hermann (1968), os documentos cartográficos nessa época eram representados como um globo em torno do qual giravam esferas celestes.

Ao reportar-se à Grécia antiga, Bakker (1965) refere-se a esse período afirmando que foram lançados os primeiros fundamentos da ciência cartográfica, quando foi utilizado o método astronômico para a determinação de posições na superfície da Terra e foi concebida a primeira solução do problema relativo ao seu desenvolvimento, sobre um plano, utilizando a projeção cônica.

Na Mesopotâmia, foram confeccionados os mapas mais antigos que a humanidade conhece. Habitada por povos como os sumérios, estabelecendo-se mais ao sul, fundaram cidades como Ur, Nippur e Babilônia entre os rios Tigre e Eufrates, onde hoje está o Iraque, e mais ao norte os povos de origem semita, como os acádios e assírios, fundando cidades como Assur e Nínive.

Esses povos foram os primeiros a introduzir a forma de comunicação escrita, em plaquetas de argila cozida, e também reproduziam os lugares por meio de símbolos gráficos, dando origem aos mapas, sendo encontradas algumas dessas peças em escavações arqueológi- 
cas, representando de modo primitivo a Babilônia, com seus estados e cidades. De acordo com Raisz (1969), a importância que para nós têm essas placas não se situa no seu mérito representativo, mas na prova evidente que proporciona sobre a significativa antiguidade da arte cartográfica.

Os mapas desse período foram responsáveis pela base do sistema cartográfico atual, sendo ultrapassados apenas no século XVI, com o advento das grandes navegações e a melhoria considerável dos documentos cartográficos.

O mapa mais antigo conhecido em nossos dias foi descoberto nas escavações das ruínas da cidade de Ga-Sur, ao norte da Babilônia. Nesse mapa de aproximadamente sete centímetros, aparece o vale de um rio, com montanhas de cada lado, representadas à semelhança de escamas de peixe, simbolizando a maneira precária com que aqueles povos representavam o relevo terrestre, e ainda círculos trazendo pontos cardeais em caracteres cuneiformes (Moura Filho, 1993).

Com relação a esse mapa, encontrado na região da Mesopotâmia, descoberto próximo à cidade de Harran, no nordeste do Iraque atual, Oliveira (1988, p.17) acrescenta: "É, a propósito de origem babilônia, o mais antigo mapa que o mundo conhece. Trata-se de um tablete de argila cozida com a representação de duas cadeias de montanhas e, no centro delas, um rio, provavelmente o Eufrates".

Na Grécia antiga, em razão da efervescência das ideias dos pensadores, alguns precursores vinculados direta ou indiretamente aos estudos do universo, cosmos, visão de mundo, fenômenos e processos naturais merecem destaque pelas suas contribuições.

\section{Sete sábios da Grécia antiga}

O período dos séculos VII e VI a.C. no qual viveram os sete sábios corresponde à época da fundação daquilo que se denominou de pólis (cidade) e da fundação da política, coincidindo com o que chamamos de civilização ocidental, e a esses eram atribuídas máximas e sentenças proverbiais conhecidas até hoje. 
Essa denominação era dada na Antiguidade a sete homens estadistas ou legisladores notáveis pela sabedoria prática. Os ensinamentos a eles atribuídos se tornaram populares e chegaram a ser inscritos no templo de Apolo em Delfos.

As atuações dos sete sábios, pelas suas ações e ideias, divulgadas e repetidas, moldaram uma nova ética e moral. Homens de prestígio, influência política e sabedoria prática se inseriram no período que se seguiu ao advento de uma nova forma de organização política, com leis e regras de conduta inovadoras, necessárias às relações humanas e à própria vida social.

Aproximam-se da geografia, quando Cícero em República (51 a.C.) escreve: "Os sete homens a quem os gregos chamaram de sábios foram todos versados na administração pública; e, realmente, em nada se aproxima tanto a virtude humana da divina como a fundação de novas nações ou a conservação daquelas já fundadas".

Os filósofos gregos que viveram entre os séculos VII e VI a.C. buscaram uma explicação do mundo em termos físicos, deixando de lado a explicação dos fenômenos naturais causados pelo mito, e procuraram explicações da necessidade da sociedade da época a partir da lógica da capacidade de raciocínio - a razão.

Conforme Morente (1972), a finalidade do homem é realizar sua natureza; e o que constitui sua natureza, aquilo que distingue o homem de qualquer outro ser, é o pensamento. Por conseguinte, o homem deve pensar. $\mathrm{O}$ ato humano por excelência é pensar.

A lista dos sete sábios não foi sempre a mesma, mas a mais difundida é a seguinte: Tales de Mileto, Periandro de Corinto, Pítaco de Metilene, Brias de Priene, Cleóbulo de Lindos, Sólon de Atenas, Quílon de Esparta.

Com as contribuições abrangendo além da filosofia da natureza, astronomia e matemática, Tales de Mileto (624-556 a.C.), notadamente para a cosmologia, preconizou a existência de um princípio ou substância fundamental, a água, para explicar a estrutura e funcionamento do cosmos. Na astronomia, contribuiu para a introdução dos seus fundamentos, aprendidos em suas viagens pelo Egito e outras regiões do Oriente. Especulou sobre as dimensões e a órbita do Sol 
e da Lua, mediu o intervalo entre os solstícios e estudou as estrelas. Na matemática, com mensurações baseadas em princípios, propôs uma série de teoremas trigonométricos.

Considerado o fundador de colônias pelo mar Adriático e por intensificar o comércio com os etruscos e o Egito, Periandro de Corinto (627-585 a.C.) investiu na dragagem dos portos para aumentar o fluxo de embarcações e espaço para construções náuticas. Fez de Corinto um centro cultural, promoveu a construção de edifícios, especialmente na arquitetura dórica, e desenvolveu a arte da pintura em cerâmica.

Ao governar Mitilene (Lesbos) após depor o tirano local, Pítaco de Mitilene (640-568 a.C.) afastou-se voluntariamente depois de dez anos. Tentou restringir o poder da nobreza e apoiou-se nas classes populares.

Considerado o mais destacado dos sábios gregos, Brias de Priene, (século VI a.C.) era constantemente consultado sobre assuntos litigiosos, negando-se a empregar seu talento em proveito da injustiça. Cleóbulo de Lindos viveu por volta de 600 a.C., sabe-se que era poeta e que compunha enigmas em versos. Governou como tirano a ilha grega de Rodas, com um governo exemplar.

Conhecido como legislador e poeta lírico e considerado um dos mais importantes legisladores da democracia ateniense, Sólon de Atenas (640-558 a.C.) instituiu a solidariedade entre as classes sociais e o tratamento justo para cada cidadão. Fez longas viagens, com descrição de lugares e povos. Essas descrições, segundo Ferreira \& Simões (1986) denominadas périplos (navegar em redor), são sobretudo conhecidas pelas referências feitas pelos escritores da Antiguidade, tendo chegado até nós muito poucas. Suas realizações políticas refletem ideais patrióticos, filosóficos e morais. Consta que sempre agiu com firmeza, moderação, sabedoria e integridade; era conciliador por natureza.

Ao ocupar o cargo de magistrado (éforo) e elaborar parte da constituição, Quilón de Esparta (séculoVI a. C.) introduziu o costume de que os éforos fossem conselheiros dos reis, sendo responsável pela militarização da vida civil em Esparta e pelas primeiras medidas para a educação dos jovens. 


\section{Filosofia pré-socrática (naturalista)}

Os filósofos pré-socráticos eram denominados naturalistas ou filósofos da phisis (natureza) entendida não como atualmente, mas como uma realidade primeira, originária e fundamental. Especulavam sobre o problema cosmológico ou cosmo-ontológico, buscando o princípio das coisas.

As principais escolas pré-socráticas e seus constituintes foram a escola Jônica, com Tales de Mileto, Anaxímenes de Mileto, Anaximandro de Mileto e Heráclito de Éfeso; a escola Itálica, com Pitágoras de Samos, Filolau de Crotona e Árquitas de Tarento; a escola Eleata, com Xenófanes de Cólofon, Parmênides de Eleia, Zenão de Eleia e Melisso de Samos; e a escola da Pluralidade, com Empédocles de Agrigento, Anaxágoras de Clazômena, Leucipo de Abdera e Demócrito de Abdera.

\section{Escola Jônica}

Os filósofos gregos da Escola Jônica podem ser considerados os primeiros geógrafos, em sentido figurado, pelo pioneirismo na concepção de um conhecimento metodológico, ao explicarem as diferenciações do mundo até então conhecido, da influência do clima, dos mares e dos rios na superfície terrestre, além do conhecimento do Universo.

Considerando a água a substância primordial que constituía a essência do universo, sendo a origem de todas as coisas, representando uma mudança de comportamento na atitude do homem perante o cosmos, Tales de Mileto (624-556 a.C.) abandona as explicações religiosas até então vigentes, buscando por meio da razão e da observação um novo sentido para o Universo.

Esboçou os princípios do pensamento teórico evolucionista, afirmando que o mundo evoluiu da água por processos naturais, e explicou o eclipse solar, ao verificar que a Lua é iluminada por esse astro. 
Ao observar mais atentamente os fenômenos da natureza, alterou os conceitos dos fenícios que consideravam os elementos da natureza (Sol, Terra, Céu, oceano etc.) como forças autônomas, verificando a constante transformação das coisas umas nas outras e que por intuição todas as coisas são uma só, ou um só princípio fundamental.

Na procura da verdade da vida na natureza realizou experiências com magnetismo e demonstrou experiências com geometria.

Considerando uma só a natureza subjacente, ilimitada, porém não indefinida, Anaxímenes de Mileto (588-524 a.C.) afirma que ela é ar, diferenciando-se nas substâncias, por rarefação (torna-se fogo) $e$ por condensação (torna-se vento, nuvem, água, terra e pedras) e as demais coisas provêm dessas, em constante movimento pelo qual se processa a transformação. Segundo essa concepção, o ar representa, no ponto de vista de Bernhardt (apud Châtelet, 1981, p.28) "um elemnto invisível e imponderável, quase inobservável e, no entanto, observável: o ar é a própria vida, a força vital, a divindade que 'anima' o mundo, aquilo que dá testemunho á respiração". Dedicando-se especialmente à meteorologia, salienta que a luz da Lua é proveniente do Sol e que o bloco fundamental de toda a matéria provinha do ar, e não da água. De acordo com Ferreira \& Simões (1986), estabeleceu o princípio do geocentrismo, que permaneceu até Galileu.

Acreditando que todos os ciclos de criação, evolução e destruição eram fenômenos naturais, que ocorriam a partir do ponto em que a matéria abandonava e se separava, Anaximandro de Mileto (610547 a.C.) chegou em sua época às mesmas conclusões dos cientistas contemporâneos, baseado apenas na observação e reflexão, de que o mundo sustenta-se por um equilíbrio de forças (Teoria da gravidade e força centrípeta, que mantêm a Terra girando em torno do Sol) e que a ação do Sol faz surgir criaturas de estrutura simples na água, que depois migram para a terra e adquirem estrutura mais complexa (Teoria da evolução das espécies).

Ensinava a evolução das coisas e das espécies, afirmando que os animais nasceram do lodo marinho e o homem teria se formado, no princípio, dentro de peixes, onde se desenvolveu e foi expulso logo que se tornou de tamanho suficiente para bastar-se a si próprio. 
$\mathrm{O}$ universo era eterno e um número infinito de mundos existiram antes do nosso. Após sua existência, eles se dissolveram na matéria primordial e posteriormente outros mundos tornaram a nascer.

Confeccionou um mapa do mundo habitado, a introdução na Grécia do uso do relógio solar, a medição das distâncias entre estrelas e o cálculo de sua magnitude. Relatos dão conta de que escreveu um livro intitulado Sobre a Natureza; infelizmente perdido.

Heráclito de Éfeso (540-470 a.C.) é o pensador do tudo flui (panta rei), do princípio de que tudo é movimento e que nada pode permanecer estático, e do Panta rei os potamós (tudo flui como um rio). Cabe a esse pensador a frase: "Todas as coisas estão em eterno fluxo e mudança. Você não é, está sendo. A história cósmica realiza-se em ciclos repetidos". No tratado Sobre a Natureza, afirma que não se pode percorrer duas vezes o mesmo rio e não se pode tocar duas vezes uma substância mortal no mesmo estado; por causa da impetuosidade e da velocidade da mutação, essa se dispersa e se recolhe.

O fogo é outro princípio, que seria o elemento do qual deriva tudo o que nos circunda, onde todas as coisas transformam-se em fogo, e esse transforma-se em todas as coisas. O universo ora se incendeia, ora de novo se compõe do fogo, segundo determinados períodos de tempo, e define dois caminhos: (i) para baixo (quando condensado o fogo umidifica e, mais consistente, torna-se água; e essa, solidificando-se, transforma-se em terra; e daí, nascem todas as coisas do mundo); e (ii) para cima (derretendo-se a terra, obtémse água que transforma-se em vapor, rarefazendo-se, transforma-se novamente em fogo).

Nosso mundo é cercado pelo Sol (mais brilhante e mais quente). Os demais astros distam mais da Terra, por isso seu brilho é menos vivo e menos quente. A Lua, que está próxima, também tem um brilho menos intenso e quente, mas por não se encontrar num espaço puro - a escuridão.

Os fenômenos naturais são consequências de diferentes evaporações; inflamando-se no círculo do Sol produz o dia, o contrário produz a noite. Quando da evaporação brilhante nasce o calor, faz verão; mas, quando da sombra o úmido prevalece, faz-se o inverno. É considerado o pai da dialética. 


\section{Escola Itálica}

Ao percorrer por trinta anos Egito, Babilônia, Síria, Fenícia, onde acumulou conhecimentos de astronomia, matemática, ciência, filosofia e religião, Pitágoras de Samos (570-496 a.C.) foi o primeiro a conceber a matemática como um sistema de pensamento, mediante provas dedutivas. Para a geografia, contribuiu com ideias inovadoras no campo da astronomia, embora nem sempre verdadeiras; como a de que a Terra é esférica e os planetas movem-se em diferentes velocidades nas várias órbitas ao seu redor.

A escola de pensamento pitagórica, interessada pelo estudo das propriedades dos números e pela observação dos astros, sugere a ideia de que uma ordem domina o universo, evidenciada no alterar-se das estações e no movimento circular das estrelas, podendo o mundo ser chamado de cosmos; conclui que a Terra é esférica, estrela entre as estrelas que se movem ao redor de um fogo central. Com a ideia de esfericidade da Terra e dos corpos celestes e a rotação da Terra, explica a alternância de dias e noites.

Filolau de Crotona (século V a.C.) escreveu um livro em que expunha a doutrina secreta de Pitágoras, contendo os mais antigos relatos sobre o pitagorismo, tendo influenciado Platão, não havendo, portanto, uma contribuição expressiva para a ciência geográfica.

Árquitas de Tarento (428-347 a.C.) escreveu sobre geometria e mecânica. Restringiu a matemática às disciplinas técnicas como geometria, aritmética, astronomia e acústica. Criou um modelo tridimensional para duplicar o cubo, vinculando-se à geografia por meio das técnicas quantitativas utilizadas atualmente.

\section{Escola Eleata}

Destacando-se pelo combate ao antropomorfismo como uma concepção filosófica, Xenófanes de Cólofon (570-460 a.C.) acreditava que só existe um deus único, em nada semelhante aos homens, que é eterno, não gerado, imóvel e puro. Buscava na natureza intrínseca 
da matéria a causa para todas as transformações, afirmando que o ser absoluto, essência de todas as coisas, era o Um e o Um é Deus.

Em um poema filosófico intitulado Sobre a Natureza, Parmênides de Eleia (530-460 a.C.) expõe seu pensamento, dividido em duas partes: o caminho da verdade e o caminho da opinião. Suas ideias sustentam a unidade e a imobilidade do Ser; o mundo sensível é uma ilusão e o Ser é Uno, Eterno, Não Gerado e Imutável. Acredita-se que daí surge o conhecimento do ser (ontologia), que trata de sua natureza, de sua realidade, da existência dos entes e das questões metafísicas. Comparou as qualidades umas com as outras e as ordenava em duas classes distintas.

Dois filósofos merecem destaque por suas contribuições em questões fundamentais sobre o pensamento concebido para a época. O primeiro, Zenão de Eleia (495-430 a.C.), pelo seu método na elaboração de paradoxos, todos contra a multiplicidade, a divisibilidade e o movimento. É considerado o criador da dialética; e o segundo, Melisso de Samos (490-430 a.C.), que produziu influência no atomismo, tornando-se um dos continuadores da escola eleática, estabelecendo que o ser é infinito, tal como é infinito no tempo, ou seja, eterno. Seu principal poema foi Sobre o Ser ou Sobre a Natureza.

\section{Escola da Pluralidade}

Sustentando a ideia de que o mundo seria constituído por quatro princípios, água, ar, fogo e terra, que seriam o que de imutável e indestrutível existiria no mundo e que tudo seria uma determinada mistura desses elementos, em maior ou menor grau, Empédocles de Agrigento (495-435 a.C.) esboçou os primeiros passos do pensamento teórico evolucionista, afirmando que sobreviveria aquele mais bem capacitado e que o mundo evoluiu da água por processos naturais, aproximando-se da geografia seja por meio dos princípios biogeográficos, seja, também, pelas bases conceituais da hidrografia.

Anaxágoras de Clazômenas (500-428 a.C.) propôs um princípio (homeomerias) que atendesse tanto às exigências teóricas do ser imu- 
tável, princípio de tudo, quanto à contestação da existência das múltiplas manifestações da realidade. As homeomerias seriam as sementes que dão origem à realidade em sua pluralidade de manifestações.

Afirmava que o universo se constitui pela ação do Nous (espírito, mente ou inteligência), ilimitado, autônomo e não misturado com nada mais, que age sobre as sementes ordenando-as e constituindo o mundo sensível. Escreveu um tratado intitulado Sobre a Natureza, em que tentava conciliar a existência ante a crítica de Parmênides de Eleia, e ainda sobre biologia, cosmologia e percepção, como uma noção de causa inteligente, que estabelece uma finalidade na evolução universal.

Sobre Leucipo de Mileto ou Abdera (500 a.C.), praticamente nada é conhecido. Especula-se como sendo o verdadeiro criador do atomismo, a quem é atribuida a autoria de um único livro intitulado A grande ordem do mundo, acreditando-se que devia tratar-se da configuração morfológica da Terra, concebida como uma unidade em constante dinamismo.

Considerado o maior expoente da teoria atômica ou do atomismo (em que tudo o que existe é composto por elementos indivisíveis), Demócrito de Abdera (460-370 a.C.) avançou com o conceito de universo infinito (onde existem outros mundos) existindo pelo menos um deles igual ao nosso. Escreveu várias obras, destacando-se Pequena ordem do mundo; Da forma; Do entendimento; Do bom ânimo e Preceitos.

\section{Contribuições do pensamento filosófico ao estudo da natureza}

Por meio de um longo processo histórico, a filosofia aparece promovendo a passagem do saber mítico com diversas crenças, ao pensamento racional, voltado para a discussão e explicação intelectualizada do que nos circunda. A passagem do mito à razão, de acordo com Châtelet (1981), significa precisamente que já havia, de um lado, uma lógica do mito, e que, de outro lado, na realidade filosófica ainda 
está incluído o poder do lendário. O contato com outras culturas propiciou o processo de desdobramento do pensamento poético (mitos) em filosófico (razão), pelo modo de pensar, e uma postura diante do mundo e não um conjunto de conhecimentos prontos, um sistema acabado e fechado em si mesmo.

Com os filósofos gregos, conforme Chauí (2000), estabeleceramse alguns princípios gerais do conhecimento verdadeiro: (i) as fontes e as formas do conhecimento (sensação, percepção, imaginação, memória, linguagem, raciocínio e intuição intelectual); (ii) a distinção entre o conhecimento sensível e o conhecimento intelectual; (iii) o papel da linguagem no conhecimento; (iv) a diferença entre opinião e saber; (v) a diferença entre aparência e essência; (vi) a definição dos princípios do pensamento verdadeiro (identidade, não contradição, terceiro excluído, causalidade), da forma do conhecimento verdadeiro (ideias, conceitos e juízos) e dos procedimentos para alcançar o conhecimento verdadeiro (indução, dedução, intuição); (vii) a distinção dos campos do conhecimento verdadeiro, sistematizados por Aristóteles em três ramos: teorético (referente aos seres que apenas podemos contemplar ou observar, sem agir sobre eles ou neles interferir), prático (referente às ações humanas: ética, política e economia) e técnico (referente à fabricação e ao trabalho humano, que pode interferir no curso da natureza, criar instrumentos ou artefatos: medicina, artesanato, arquitetura, poesia, retórica etc.).

O pensamento filosófico é uma prática de vida que estuda os acontecimentos além de sua pura aparência, refletindo sobre a realidade, redescobrindo seus significados mais profundos, podendo se voltar para qualquer objeto. Ciência, valores, métodos, religião, arte e o próprio homem podem ser objetos da reflexão filosófica, além de questionar o modo de ser das pessoas, das culturas, do mundo, das práticas políticas, científicas, técnicas, éticas, econômicas, culturais e artísticas. A ciência, segundo Bronowski (1979), é a criação de conceitos e das suas explorações nos fatos. Não existe outro exame de conceito que não seja a verdade empírica do fato. A verdade é o estímulo no centro da ciência; tem de ter o hábito da verdade, não como dogma, mas como processo. 
Os filósofos figuram como precursores do conhecimento voltado para a natureza e cosmovisão, destacando-se os que se seguem.

Ao viajar pela Índia, Megástenes (350-290 a.C.) escreveu a obra Índica, na qual descreve a cordilheira do Himalaia e a ilha Sri Lanka, denominando de Taprobanê (flor da cor de cobre) em razão da vegetação característica dessa ilha.

Durante a realização de uma viagem de exploração ao noroeste da Europa, circum-navegando a Grã-Bretanha, Píteas (380-310 a.C.) foi o primeiro autor greco-romano a descrever o sol da meia-noite, a aurora polar e os gelos polares, e a mencionar as tribos germânicas. Relatou suas viagens num documento intitulado Do oceano, do qual apenas partes sobreviveram. Informou ter visitado uma ilha a seis dias de viagem do norte da Escócia denominanda Thule, acreditandose que tenha sido a Islândia ou a costa da Noruega.

Ao descrever países e habitantes, sendo o relato do Egito particularmente completo, Hecateu de Mileto (546-480 a.C.) viajou por parte do mundo conhecido, que segundo Ferreira \& Simões (1986) era constituído por uma faixa que se estendia do Atlântico ao Rio Indo, as regiões Norte e Sul eram pouco conhecidas. Confeccionou um mapa baseado no de Anaximandro, que corrigiu e acrescentou, onde a Terra estava representada por um disco com água em volta. Acredita-se haver escrito um trabalho nomeado Ges Periodos (Descrição da Terra) resumindo os conhecimentos geográficos gregos da época, dividida em um volume dedicado à Europa e outro à Ásia. Escreveu ainda outras obras, entre elas Inquéritos e Circuito da Terra, que interessam particularmente à geografia.

Considerado o filósofo que mais influenciou o pensamento ocidental, Aristóteles (384-322 a.C.) demonstrou interesse por biologia e fisiologia, decorrente da atividade médica exercida pela família e da preferência pela ciência, quando entrou na academia de Platão, permanecendo por vinte anos.

Suas teorias sobre as causas (material, formal, eficiente e final), como se age no interior das coisas, estendem-se sobre toda a natureza.

Contribuiu para diversas áreas do conhecimento humano, cobrindo campos como filosofia, biologia, zoologia, história natural, 
física, metafísica, lógica, ética, política, psicologia, poesia, retórica e medicina, estabelecendo as bases dessas disciplinas.

Em 344 a.C., partiu para Lesbos, onde realizou a maior parte das investigações biológicas. Fundou, no ano seguinte, o Lykeion (Liceu), onde os alunos ficaram conhecidos como peripatéticos (os que passeiam), nome decorrente do seu hábito de ensino ao ar livre, sob as árvores, privilegiando as ciências naturais, com exemplares (flora e fauna) enviados por Alexandre, o Grande, das regiões conquistadas.

Considerado o verdadeiro fundador da zoologia, levando-se em conta o sentido etimológico da palavra, deve-se a ele a primeira divisão do reino animal. Formulou a teoria da abiogênese, que durou séculos, segundo a qual um ser nascia de um germe da vida, sem que um outro ser precisasse gerá-lo (exceto os humanos).

Iniciou os estudos científicos documentados sobre peixes, sendo o precursor da ictiologia, catalogando mais de cem espécies de peixes marinhos e descrevendo seu comportamento.

Aproxima-se mais ainda da geografia quando estuda o cosmos, apresentado como uma esfera finita, onde se prendiam as estrelas e dentro da qual se verificava uma rigorosa subordinação de outras esferas, que pertenciam aos planetas que giravam em torno da Terra, que se manteria imóvel no centro do sistema (sistema geocêntrico).

Os corpos celestes não seriam formados por nenhum dos quatro elementos transformáveis (terra, água, ar e fogo), mas por um elemento não transformável designado "quinta essência".

O conjunto de suas obras é conhecido como Corpus Aristolelicum, começando pelo Organon, composto por Categorias, Sobre a interpretação, Analíticos, Tópicos e elencos sofísticos. A seguir aparecem os estudos sobre a natureza e o mundo físico, com: Física; Sobre o céu e Meteorológicos. Segue-se a Parva Naturalia, conjunto de investigações sobre temas diversos, incluindo: História dos animais; Das partes dos animais; Do movimento dos animais; Da geração dos animais; Da origem dos animais, sendo considerados os trabalhos precursores da biogeografia, em especial a zoogeografia. Finalmente, as obras dedicadas à Metafísica e aquelas vinculadas a Ética, Política, Retórica e Poética. 
Desenvolvendo a noção de que o homem está em contato permanente com dois tipos de realidade: a inteligível (igual a si mesma) e a sensível (todas as coisas que nos afetam os sentidos), Platão (428-347 a.C.) ajudou a construir os alicerces da filosofia natural, da ciência e da filosofia ocidental, afirmando que são realidades dependentes e mutáveis, conhecidas por Teoria das ideias ou Teoria das formas. Segundo Schüller (1985), Platão localiza na psique três seções correpondentes à divisão do Estado, a razão, a vontade e as paixões. Cabe à razão descobrir as leis que regem o homem, a tarefa da vontade é executá-las, espera-se que as paixões as cumpram. A vontade regida pelas paixões leva a desmandos semelhantes aos que ocorrem no Estado governado pelo povo. Tratou ainda de diferentes temas, como ética, política, metafísica e teoria do conhecimento, evidenciadas em seus 35 diálogos, entre eles Timeu, que trata da origem do universo.

Theophrastus (371-287a.C) realizou estudos em ética, história, lógica, metafísica e história natural. Considerado o pioneiro da botânica, iniciou os estudos científicos das plantas, com a criação do primeiro jardim botânico ocidental, em Atenas.

Duas obras deste precursor da biogeografia constituem-se na primeira sistematização do mundo botânico, consideradas as maiores contribuições a essa ciência durante a Antiguidade e a Idade Média. A primeira, Enquiry into Plants, trata das partes, reprodução, horários e forma de semeadura das plantas. Dedica-se também às árvores, arbustos e plantas espinhosas abordando os tipos, locais e aplicações práticas. Trata ainda das ervas, de plantas que produzem sementes comestíveis e as que produzem sucos.

A segunda On the Causes of Plants, trata de crescimento, influências sobre fecundidade, época apropriada de semeadura e colheita, métodos de preparação do solo, utilização de ferramentas e usos econômicos e medicinais das plantas. Publica ainda, entre outras obras: Principles of Natural Philosophy (Physica Auscultatio); Meteorological Phenomena; Warm and the Cold, Water, Fire, the Sea; Coagulation and Melting e Sensuous Perception.

Utilizando-se da teoria atômica de Demócrito para justificar a constituição de tudo o que existe, das estrelas à alma, tudo é formado 
de átomos de diferentes naturezas, de qualidades finitas, quantidades infinitas e sujeitos a infinitas combinações, Epicuro de Samos (341-270 a.C.) afirma que, ao compreender como opera a natureza, o homem pode livrar-se do medo e das superstições que afligem o espírito.

Essa teoria tinha a finalidade de explicar todos os fenômenos naturais conhecidos ou ainda não e extirpar o medo da morte e dos deuses. Fundou sua própria escola filosófica intitulada O Jardim, buscando na natureza o direcionamento para seu pensamento, afirmando que o homem, a exemplo dos animais, busca afastar-se da dor e aproximar-se do prazer. Sua obra versa sobre natureza, meteoros e a moral.

Heródoto (485-420 a.C.), reconhecido como pioneiro da história, bem como da etnografia e da antropologia, conheceu e estudou em pormenor os locais onde tinham ocorrido fatos históricos sobre os quais escreveria. Percorreu o mundo habitável conhecido, do Sudão até a Ucrânia e da Índia até o Estreito de Gibraltar (Ferreira \& Simões, 1986). Sua obra Histórias, dividida em nove livros, foi acusada de imprecisa e plagiária, especialmente em razão do exagero na extensão de suas viagens e fontes criadas. Hipócrates (460-377 a.C), pelas viagens à Grécia e ao Oriente Próximo, com descrições pelas quais se podem diagnosticar doenças relacionadas aos fatores climáticos, ao meio onde as pessoas viviam e à raça, contribuiu de forma significativa para a obra de Heródoto.

Com contribuições de ordem prática no desenvolvimento da ciência geográfica, aparece Eratóstenes de Cirene (285-194 a.C.), que criou a esfera armilar, antigo instrumento astronômico composto por um conjunto de arcos destinado a representar as posições de círculos importantes da esfera terrestre.

Eratóstenes calculou com bastante precisão para a época a distância da Terra ao Sol e elaborou um catálogo com 675 estrelas, medindo a inclinação da eclíptica. Foi o primeiro a medir o raio da Terra, suspeitando que essa fosse esférica, e com o auxílio da trigonometria mediu com relativa precisão o perímetro da circunferência máxima. Calculou as medidas para a determinação do círculo máximo do 
globo terrestre, chegando ao valor de 45 mil quilômetros, e confeccionou um mapa com novas informações da verdadeira dimensão dos continentes.

Considerado o fundador da astronomia científica e da trigonometria, Hiparco (190-126 a.C.) introduz na Grécia os conhecimentos babilônicos sobre a graduação sexagesimal do círculo, e a partir daí define a rede de paralelos e meridianos do globo terrestre. Rejeitou a teoria heliocêntrica e criticou a obra geográfica de Eratóstenes, empregando rigorosos princípios matemáticos para a localização de pontos na superfície da Terra. Descobriu a precessão dos equinócios e criou o sistema de localização pelo cálculo da longitude e latitude. Realizou a divisão do mundo em zonas climáticas e concebeu o método de projeção estereográfica.

Com referência a autores que contribuiram de forma efetiva nesse período para a concepção da ciência geográfica, destaca-se Estrabão (63 a.C.-24 d.C.), autor de Geographia, um tratado de dezessete livros contendo a história e as descrições de povos e locais do mundo conhecido à época. Não se sabe ao certo quando a obra foi escrita, presumindo-se ano 7 d.C. Apesar dos erros, essa obra foi a primeira desse gênero herdada da Antiguidade. Conforme Estrabão, "a Geografia [...] nos parece ser, como algumas outras ciências, do domínio da Filosofia [...] a variedade de aplicações que é susceptível á Geografia, que pode servir, por sua vez, às necessidades dos povos e aos interesses dos chefes... implica que o geógrafo tenha esse mesmo espírito filosófico habituado a meditar sobre a grande arte de viver e de ser feliz".

Na definição dos princípios da geografia matemática e estabelecimento, pela primeira vez, da posição astronômica de numerosos lugares e cidades, especialmente na zona mediterrânea, Marino de Tiro (210-150 a.C.) foi pioneiro na projeção cartográfica empregando o rigor matemático e lançando os conceitos de latitude e longitude, não em relação às distâncias, mas em graus. Na geografia, deixou cartas geográficas das sete regiões do mundo, afirmando que a Terra era redonda, com paralelos e meridianos, que traçaram ao mundo futuro precisões geográficas cronológicas. Nas suas cartas retan- 
gulares, os meridianos e os paralelos da esfera são representados por dois sistemas de retas paralelas equidistantes, em uma escala arbitrariamente escolhida, com as retas de um dos sistemas perpendiculares às do outro.

Com sua obra Geographia em oito volumes, contendo todo o conhecimento geográfico greco-romano, Ptolomeu (90-168 d.C.) inclui coordenadas de latitude e longitude para os lugares mais importantes, com observações astronômicas em Alexandria, e escreve sua principal obra, denominada Megalé Sintaxis, ou Grande construção, que trata da Terra, do Sol, da Lua, do astrolábio e de cálculos matemáticos, das elipses, um catálogo de estrelas, e, finalmente, os cinco planetas e suas diversas teorias. A obra intitulada Almagesto, um tratado de astronomia, descreve o conhecimento babilônico e grego, apresentando um sistema cosmológico geocêntrico, tornando-se uma das obras mais importantes da Antiguidade clássica. É autor, ainda, de Tetrabiblos, um livro de astrologia baseado em escritos e documentos antigos da Babilônia, da Grécia e do Egito.

A obra de Ptolomeu aceita as medidas do grado e estabelece, por meio de cálculos, o comprimento do círculo máximo da Terra, para o qual obteve o valor de trinta mil quilômetros. O erro associado a essa medida origina a falsa impressão de que a Europa e a Ásia se estendiam por mais da metade de toda a longitude terrestre, quando realmente cobre apenas 130 graus. Confeccionou um mapa com base nas informações descritas àquela época, que, apesar dos erros e deformações, permitiu reconstruir uma nova visão do mundo.

Viajando por Grécia, Ásia Menor, Síria, Palestina, Macedônia e Península Itálica, e baseado em observações próprias e informações de outros autores, Pausânias (115-180 d.C.) prestou uma importante contribuição para o conhecimento da Grécia antiga, graças às descrições das localidades. É autor da Descrição da Grécia, conhecida como Viagem pela Grécia ou Itinerário da Grécia, composta de dez livros

Considerados os filósofos da natureza, esses pensadores dedicaram parte de seus escritos às ciências naturais, com ideias valiosas e significativas contribuições. 
Realizando observações sobre a natureza, especialmente sobre o aspecto da percepção emocional e psicológica, produziram escritos, reflexões teóricas e metodológicas nas mais divesrsas áreas do conhecimento humano.

Ocuparam-se sistematicamente com pesquisas na área das ciências naturais, demonstrando interesse principalmente por cosmologia (cartografia); seus métodos de análise não se restringiam à geografia, mas também abrangem a teoria do conhecimento e das ideias.

Considerando a filosofia uma característica de todas as realidades naturais e humanas e que todo o universo poderia ser entendido a partir de uma perspectiva histórico-evolutiva, estabeleceram e realizaram estudos sobre diversos temas, povos, lugares, linguagem etc., capazes de evoluírem e crescerem continuamente.

\section{Conclusões}

A natureza como algo que desperta a curiosidade e admiração conduz o homem a estudá-la, nascendo então a filosofia e um significativo número de outras ciências, no gênero das positivas. Pode-se perceber, então, que a natureza não é todo o ser, mas um ser particular, ainda que bastante amplo.

Aos primeiros filósofos se têm denominado físicos ou naturalistas, pois se concentraram na cosmologia, transitando depois pela psicologia, pela ontologia e pela ética.

No plano das ideias filosóficas, distingue-se o ser em geral, de que trata a metafísica e os seres especiais, tratados pela filosofia natural; nessa são conhecidas a cosmologia e a psicologia.

Neste trabalho, foi tratada apenas a cosmologia, sem o psiquismo, abordando apenas os corpos (entendidos como matéria) e os fenômenos da vida (no sentido biológico) como neles ocorrem.

Os filósofos sempre tentaram explicar a natureza e seus fenômenos, caindo inevitavelmente em contradições, em razão da expansão da filosofia que englobou áreas além de sua simples descrição, incluindo o estudo do homem e todos os fenômenos relacionados a ele e ao seu pensamento. 
As contradições entre os filósofos continuariam, no entanto, a afligir o espírito humano por séculos, quer em relação aos métodos, quer em relação às teorias, quer em relação aos fenômenos.

Aos sete sábios couberam ações e ideias, divulgadas e repetidas, responsáveis pela introdução de uma nova ética e moral, por causa do prestígio, da influência política e da sabedoria prática que dispunham, ensejando o advento de uma nova forma de organização política e institucional, com leis de conduta inovadoras, necessárias as relações sociais.

Os filósofos pré-socráticos, ao iniciarem a interrogação filosófica, principiaram-na pelos componentes das coisas naturais e pelas causas das suas mutações, onde todas as coisas eram originadas e se compunham de elementos naturais, e ainda sobre a investigação das causas das alterações, imaginando forças opostas conflituosas e em busca de equilíbrio, e que os elementos originários eram compostos e se complementavam de um princípio potencial (matéria) e outro determinador (forma).

Viram-se então obrigados a criar uma visão de mundo cujas leis fossem estáveis e confiáveis, aparecendo assim os conceitos de ordem do mundo (kosmos) e de natureza (physis), que os afastou das incertezas.

Apesar de ainda existirem inúmeras religiões, que se baseiam nas noções de um universo caótico na dependência dos atos humanos, foi dos conceitos de kosmos e de physis que surgiram a cultura ocidental, a filosofia e a ciência, e daí a geografia.

\section{Referências}

ABBAGNANO, N. Dicionário de filosofia. São Paulo: Mestre Jou, 1982.

BAKKER, M. P. R. de. Cartografia - Noções básicas. Rio de Janeiro: Marinha do Brasil, Diretoria de Hidrografia e Navegação, 1965.

BERNHARDT, J. O pensamento pré-socrático: de Tales aos sofistas. In: CHÂTELET, F. História da filosofia - Idéias e doutrinas. Rio de Janeiro: Zahar, 1981. v.1.

BOCHENSKI, I. M. A filosofia contemporânea ocidental. São Paulo: EPU/ Edusp, 1975. 
BORNHEIM, A. G. Introdução ao filosofar. Rio de Janeiro: Record, 1980.

CHÂTELET, F. História da filosofia - Idéias, doutrinas. Rio de Janeiro:

Zahar, 1981.

CHAUÍ, M. Convite à filosofia. São Paulo: Ática, 2000.

CLOSIER, R. História da geografia. Lisboa: Europa-América, 1972.

CORBISIER, R. Introdução à filosofia. Rio de Janeiro: Civilização Brasileira, 1986.

DURANT, W. História da filosofia. São Paulo: Nacional, 1956.

FERREIRA, C. C.; SIMÕES, N. N. A evolução do pensamento geográfico. Lisboa: Gradiva Publicações Ltda., 1986.

GILES, T. R. Introdução à filosofia. São Paulo: EPU/Edusp, 1979.

GRIMAL, P. A mitologia grega. São Paulo: Difusão Europeia, 1954.

HEGENBERG, L. Introdução à filosofia da ciência. São Paulo: Herder, 1965.

HERMANN, P. História dos descobrimentos geográficos. Barcelona: Editorial Labor, 1968.

JOLIVET, R. Curso de filosofia. Rio de Janeiro: Agir, 1972.

LENCIONI, S. Região e geografia. São Paulo: Edusp, 2003.

LINS, I. Escolas filosóficas ou Introdução ao estudo da Filosofia. Rio de Janeiro: São José, 1955.

MARÍAS, J. Introdução à filosofia. São Paulo: Livraria Duas Cidades, 1978.

MORA, J. F. Dicionário de filosofia. Lisboa: Publicações Dom Quixote, 1982.

MORENTE, M. G. Fundamentos de filosofia. São Paulo: Mestre Jou, 1972.

MOTES, J. M. de. (Org.) A conquista da Terra. Lisboa: Salvat Editores e Editorial Verbo, s. d.

MOURA FILHO, J. Elementos de cartografia. Belém: Falangola, 1993.

OLIVEIRA, C. de. Curso de cartografia moderna. Rio de Janeiro: IBGE, 1988.

Dicionário cartográfico. Rio de Janeiro: IBGE, 1993.

PINTO, A. V. Ciência e existência: problemas filosóficos da pesquisa científica. Rio de Janeiro: Paz e Terra, 1979.

POLITZER, G. Curso de filosofia. Rio de Janeiro: Editorial Antes, 1957.

RAISZ, E. Cartografia geral. Rio de Janeiro: Editora Científica, 1969.

RUSSEL, B. Delineamentos da filosofia. São Paulo: Nacional, 1954.

História da filosofia ocidental. São Paulo: Nacional, 1982.

SCHÜLLER, D. Literatura grega. Porto Alegre: Mercado Aberto, 1985.

SIMAAN, A.; FONTAINE, J. A imagem do mundo dos babilônios a Newton. São Paulo: Cia. das Letras, 2003. 


\section{2 \\ Alexander Von Humboldt: VIAJANTE NATURALISTA E ENTUSIASTA DA HARMONIA DA NATUREZA}

Danilo Piccoli Neto*

Flamarion Dutra Alves**

\section{Introdução}

Este texto centrar-se-á nos noventa anos entre o nascimento e o falecimento de Humboldt, em sua trajetória intelectual, política, especialmente enfocando o caráter humano e o contexto social do naturalista prussiano.

Propõe-se também com o texto, em segunda instância, adentrar de forma geral o legado científico deixado por Humboldt, que extravasa a data de seu falecimento, adentra o início da constituição da geografia como ramo do saber científico e, portanto, oferece rico material teórico e metodológico para o corpus inicial da disciplina, tendo influências e contribuições pertinentes até a presente data.

As obras de Humboldt são um legado à posteridade da sistematização e constituição do pensamento científico moderno que se estruturava durante o século XIX; ao mesmo tempo, marcam o final da era dos grandes homens detentores de conhecimentos vastos, abarcando diversos ramos do saber.

* Doutorando em Geografia do Programa de Pós-Graduação em Geografia, Unesp - Rio Claro (SP). Bolsista Fapesp.

** Doutorando em Geografia do Programa de Pós-Graduação em Geografia, Unesp - Rio Claro (SP). Bolsista CNPq. 
Por fim, este texto não deixa de ser uma homenagem e um reconhecimento ao célebre Alexander Von Humboldt, que no ano de 2009 teve completos 150 anos de seu falecimento.

\section{Educação e contribuições à ciência em geral}

Todo cientista é um descendente de Humboldt. Estamos todos em sua família.

(Emil Du Bois-Reymond ${ }^{1}$ )

Em Berlin, no principado de Brandenburgo, em 14 de setembro de 1769, nascia Friedrich Wilhelm Heinrich Alexander Freiherr Von Humboldt, homem que viria a contribuir de maneira extremamente frutífera para o conhecimento científico, e que faria parte do quadro de personalidades marcantes dos séculos XVIII e XIX, ao lado dos maiores naturalistas, cientistas e homens dotados de um espírito de conhecimento e vontade de desbravar as fronteiras de um novo mundo. Mundo esse entendido tanto como as sociedades e fenômenos que se apresentavam exteriores ao mare nostrum europeu e que estavam encobertos aos olhos daquela sociedade por séculos, quanto como as fronteiras do próprio saber humano, que avançavam largamente na velocidade a vapor e nos adventos ópticos que enxergavam do micro ao macrocosmos.

Seu intelecto pôde ser desenvolvido sem grandes percalços materiais no castelo de Tegel. Era filho de família nobre, seu pai, o maçom e major Alexandre George Von Humboldt, era estandarte e amigo do rei Frederico da Prússia, o que lhe possibilitou dispor de bens e recursos para engendrar seus projetos e sonhos mais ousados. Sua tolerância e apresso pela liberdade podem ser fruto da pluralidade de seu próprio núcleo familiar, uma vez que sua mãe, Maria Elisabeth Von Colomb, também detentora de considerável fortuna, viúva do

1 Médico e fisiologista alemão, descobridor do potencial de ação em nervos e fundador da eletrofisiologia. 
barão Holwede, descendia de franceses Huguenotes da Borgonha, que tiveram de se refugiar na Alemanha após a revogação do Édito de Nantes (Aragão, 1960, p.467). O núcleo familiar era completo contando com seu irmão mais velho, Guilherme de Humboldt, também dotado de um intelecto marcante nas fronteiras do saber, re-estrutarador da Universidade de Berlin e um dos responsáveis pela criação da cátedra de geografia, a qual Humboldt ocuparia já em idade avançada.

Alexander Von Humboldt estudou seis meses de finanças na Universidade de Frankfurt an der Oder, adquirindo consistente formação em economia política por intermédio do fisiocrata Wilhelm Dohm (Capel, 2007), e seu apreço pela botânica pôde ser mais refinado nas aulas do professor Wildenow. Posteriormente, esteve na Universidade de Göttingen, importante centro para estudos físicos, contando com eminentes cientistas como Heyne e Blumenbach (Bruhns, 1873). Nesta última, pode conviver e ouvir os relatos de George Adan Foster, jovem escritor com fama já consagrada pelos relatos da viagem com James Cook. Durante as férias de 1789, realizou excursão científica no Reno, resultando no tratado Mineralogische Beobachtungen über einige Basalte am Rhein, 1790 (ibidem). Outro colega de universidade seria Andrés Del Rio, mexicano que agregaria ânimo ao ideário e ímpeto expedicionário do jovem prussiano na Escola de Minas de Freiburg, local onde Humboldt cursou engenharia e se aprofundou nos ramos da geologia, sob auspícios de A. G. Werner. Em Hamburgo, viria a se concentrar nos estudos de comércio e em línguas clássicas (Aragão, 1960, p.468; Penna, 1960, p.678).

Publicaria, em 1793, Florae Fribergensis Specimen, resultado das pesquisas sobre as vegetações encontradas nas minas e Versuche über die gereizte Muskel- und Nervenfaser (1797), sobre a irritabilidade muscular, fato recém-descoberto por Luigi Galvani. Ingressou no grupo de Weimar em 1794, onde contribuiu para o novo periódico de Schiller, Die Horen, com a alegoria filosófica Die Lebenskraft, oder der rhodische Genius, 1795, artigo que demonstra características do vitalismo e que o acompanhou, em certos aspectos, até a idade madura (Bruhns, 1873). 
Na estrutura científica de sua época, Humboldt se destacou como naturalista, abarcando os campos da zoologia, química, astronomia, sociologia, física, geologia e botânica, mas foi à geografia que o prussiano dedicou especial atenção e é considerado, até mesmo, um dos fundadores do ramo da geografia física (termo que empregava diferentemente do contexto atual, e que às vezes constava como física terrestre ou física do mundo). Essa perspectiva é evidenciada nas palavras de Aragão (1960, p.465): "só não avançou mais, só não foi muito além nos seus ensinamentos, por se ter limitado ao campo geográfico, demasiado amplo para os conhecimentos ainda rudimentares dos cientistas de sua época".

Dessa maneira, além das reconhecidas contribuições à geografia, foram realizadas importantes contribuições ao conhecimento em geral. Em conjunto com Gay Lussac, realizou decomposição analítica do ar, resultando na descoberta das proporções de oxigênio e hidrogênio na composição da água no ano de 1805, fato esse que foi o estágio inicial das pesquisas de Lussac para a posterior lei sobre a dilatação dos gases, denominada Lei de Gay-Lussac (Aragão, 1960, p.468). No campo arqueológico, fez constatações importantes sobre a cronologia das civilizações pré-colombianas do Peru e do México, desmistificando a associação linguística dessas civilizações com o greco-romano, como havia sido proposto até então (Herrmann, 1960).

Em seu ambiente social, Humboldt pode relacionar-se com grandes personalidades da época, como Goethe e Schiller, durante sua estada em Jena, em 1797, onde tomaria contato com os ensinos de J. C. Loder sobre anatomia, e F. Von Zach e J. G. Köhler sobre astronomia. Os naturalistas George Foster e Aimé Bonpland seriam importantes bases formativas (Penna, 1960, p.678). Em Paris, cidade a qual, na efervescência da era das luzes, lhe permitiu conhecer Cuvier, ${ }^{2}$ Delambre, ${ }^{3}$

2 Barão Georges Cuvier. Naturalista francês que formulou as leis da anatomia comparada.

3 Jean Baptiste Joseph Delambre. Matemático e astrônomo francês. Solicitou à Academia de Ciências Francesa uma base de medidas universalmente aceita, da qual, após inúmeros encontros, resultou o metro. 
Jussieu, ${ }^{4}$ Desfontaines, ${ }^{5}$ Laplace, ${ }^{6}$ Fourcroy ${ }^{7}$ e Berthollet, ${ }^{8}$ aprofundando-se nas leituras de Kant.

Humboldt seria ainda um grande fomentador das ciências, quando aos sessenta anos, por convocação da corte do rei Frederico Guilherme da Prússia, ocuparia a função de conselheiro científico e artístico (Penna, 1960, p.680). Realizaria também funções de Estado, como acessor do Departamento de Mineração e Fusão de Minérios em Berlim e diretor geral das Minas da Francônia (Aragão, 1960, p.468).

É corrente na atualidade o pensamento de que as grandes ideias que sustentam amplas matrizes de pensamento não se fazem sozinhas, e esse cenário de efervescência cultural em que Humboldt viveu em muito será basilar para sua formação, suas contribuições e seu reconhecimento como grande naturalista.

\section{Um homem aberto ao conhecimento e a desbravar o mundo}

Ele foi o maior cientista viajante, que já viveu - Eu sempre o admirei, agora eu o adoro.

$\left(\right.$ Charles Darwin $\left.{ }^{9}\right)$

Desde há muito tempo, Humboldt foi daqueles cuja personalidade preencheu o espírito dos europeus que lançavam suas expectativas, so-

4 Antoine Laurent de Jussieu. Médico e botânico francês, idealizador do sistema taxonômico de plantas denominado "Sistema de Jussieu".

5 René Louiche Desfontaines. Botânico francês.

6 Pierre Simon Laplace. Matemático, astrônomo e físico francês que organizou a astronomia matemática. Formulou a "Equação de Laplace", equação diferencial de extrema relevância utilizada em largos campos da ciência.

7 Antoine François de Fourcroy. Químico e político francês descobridor do fosfato de magnésio; criador do Museu Nacional de História Natural e re-estruturador do ensino superior, colégios e liceus franceses.

8 Claude Louis Berthollet. Químico francês, definiu pela primeira vez o conceito de equilíbrio químico.

9 Carta enviada pelo renomado biólogo no período de sua viagem no HMS Beagle ao seu tutor, o botânico e geólogo britânico John Stevens Henslow. 
nhos e curiosidades para o além-mar, desejosos em desbravar os novos mundos "intocados", que pouco a pouco começavam a se integrar em um sistema de mundo unificado. Quando, aos oito anos de idade, a criança Humboldt deparou-se com a questão do então rei da Prússia, Frederico, o Grande, se desejaria ser um conquistador, seu espírito respondeu: "Sim, Sire, mas com a minha cabeça" (Aragão, 1960, p.467).

Quando não por problemas familiares, foram as celeumas políticas que se mostraram imensos entraves para seu sonho de desbravamento. O pai faleceu precocemente, deixando um Humboldt extremamente ligado à persona materna, o que foi um obstáculo a viagens mais longas, só possíveis com o falecimento da mãe. Fato político e histórico notório foi o cerco empreendido pela armada britânica ao continente Europeu.

O Diretório francês planejava um projeto de circum-navegação, e tão logo Humboldt tenha tomado conhecimento, inscreveu-se para integrar a equipe de cientistas. A viagem, no entanto, foi suspensa e convertida posteriormente por Napoleão a uma expedição à África. O comandante militar francês vira-se fascinado com o Egito, e no desejo de catalogar e relatar tais fascínios, procurou reunir 160 cientistas renomados da época para tal tarefa (ibidem, p.468). Pelas características imprevisíveis que o curso da história reserva, a expedição não logrou sucesso, pois, nos momentos que precediam a partida dos navios de Marselha, a esquadra britânica, comandada pelo almirante Nelson, infligia pesada derrota à armada francesa em Abukir, colocando a Europa em bloqueio continental (ibidem, p.468). Mais uma vez, Humboldt veria seu desejo postergado.

Depois de outra tentativa fracassada, Humboldt segue com o amigo Bonpland para a Espanha, com o intuito de chegar à América. De posse de um plano expedicionário, seguem para um diálogo com o secretário de Estado, Dom Mariano Luiz de Urquijo, e, além disso, Humboldt, sendo de família nobre, dispondo de relações privilegiadas, contou com o apoio do embaixador saxônico, barãoVon Forelli, para uma anuência com o rei de Espanha, Carlos IV (ibidem, p.470). Essa anuência é de extrema importância, pois é nela que Humboldt, além da permissão conseguida para o Novo Mundo, consegue uma carta do rei com 
instruções a todos os capitães-generais, comandantes de província, governadores, enfim, aos diversos funcionários da coroa, para que facilitassem de todas as maneiras a passagem dos viajantes pela América Espanhola. (ibidem, p.470)

Diener (2001, p.107) nos dá a dimensão desse fato para o logrado sucesso alcançado pelas obras pós-expedição, colocando que, se, por um lado, Humboldt menciona um rico referencial bibliográfico de autores hispânicos e hispano-americanos abarcando do século XVI ao XIX, por outro, ele teve acesso a um tipo de informação extremamente relevante, que era guardada sob grande sigilo, como documentos confidenciais de circulação restrita ou mesmo nula fora do fechado âmbito espanhol, e pela receptividade da coroa ao reconhecido cientista, o prussiano teve acesso praticamente ilimitado a esse legado científico gigantesco. Diener complementa: "equipado com uma sólida formação científica e achando-se em posse de fortuna pessoal considerável, [Humboldt] pôde tirar o máximo proveito da sua viagem e avançar nos estudos americanistas durante seu trajeto" (ibidem).

Em 15 de julho de 1799, aportavam em Cumaná, Venezuela, Humboldt e o companheiro Bonpland, após praticamente um mês de viajem da partida de La Corunã, em 5 de junho de 1799, no veleiro El Pizarro. Após novembro, rumaram para Caracas, com Bonpland por terra e Humboldt por mar. Nessa cidade, levantaram dados científicos, como medição de temperatura do ar, e adquiriram equipamentos para ultrapassar os lhanos rumo ao Orenoco; permaneceram no local até fins de 1800. Da viagem empreendida ao Orenoco, podem-se relatar a descoberta de espécies animais e vegetais e, especialmente, a confirmação definitiva das ligações entre as bacias do Orenoco e do Amazonas, que ainda permaneciam ignoradas pelas sociedades geográficas europeias (ibidem, p.472). Interessante observar a percepção de Humboldt para com os ameríndios, pois, de acordo com Diener (2001, p.113), o prussiano "faz referência à vida dos índios e às relações empíricas que estes mantêm com a geografia, que os leva a ser, em suas palavras [de Humboldt], 'excelentes geógrafos' e, portanto, uma boa fonte de informação”. 
É digna de nota a capacidade de Humboldt para coadunar conhecimentos adquiridos, que, utilizando-se de coordenadas astronômicas, pode colocar com precisão incrível para a época a localização de diversas áreas, como o lago Guaiania, cuja localização era desconhecida e de atributos místicos. É nesse ponto da viajem que Humboldt trava contato com oficiais portugueses, já devidamente alertados em ordem régia ao capitão-geral do Pará, Dom Francisco Maurício de Souza Coutinho, para

examinar com o maior cuidado se um tal barão de Humboldt ou outro qualquer estrangeiro, andava viajando pelo território daquela capitania, pois constava, que o tal barão, natural de Berlin, andava explorando as partes superiores da capitania do Maranhão, regiões desertas e até então desconhecidas de todos os naturalistas. (Carvalho apud Penna, 1960, p.681)

E assim, as relações de Estado prevaleceram sobre as relações de ciência e pesquisa, no conhecido caso em queé negada a permanência de Humboldt em território português, e onde ele e o amigo Bonpland são encarcerados e têm seus bens e anotações confiscados, somente livres do cárcere pela intervenção do padre jesuíta Zéa (Aragão, 1960, p.472).

Do saldo do trajeto de Caracas até Angusturra, têm-se mais de três mil quilômetros de rios navegados e dezesseis mil itens colecionados e inventariados, dentre plantas, peles, rochas etc. (ibidem, p.472). Em 18 de dezembro de 1800, Humboldt e Bonpland se encontravam em Havana, onde pretendiam integrar a expedição de circum-navegação do globo empreendida por Baudin, porém os navios acabavam de zarpar da Europa, o que fez que Humboldt aproveitasse o tempo para viajar até Lima, à espera das embarcações. Durante esse percurso, aportam em Cartagena onde seguem por terra até Santa Fé de Bogotá, cidade na qual encontram o botânico José Celestino Mutis, responsável pela Expedición Botánica e que forneceu importantes conhecimentos sobre o ar atmosférico andino (ibidem, p.473). 
Em janeiro de 1802, estavam em Quito, local no qual Humboldt parece desenvolver com mais afinco a percepção sobre os modos de vida do povo das colônias, especialmente o habitante nativo que guardava os costumes da pré-colonização. Em contato com a história inca e vendo na prática o trato com o habitante da colônia, o naturalista coloca em seus relatos e nas cartas endereçadas a seu irmão o repúdio aos atos praticados pelos espanhóis e antevê na efervescência das ruas o sentimento latente de liberdade, que culminaria na independência das colônias. O padre botânico Zéa e o assistente de Mutis, Francisco José de Caldas, desempenharam papel importante na contextualização dos fatos cotidianos e nos anseios do povo para os relatos de Humboldt. Zéa e Caldas foram executados posteriormente pela justiça espanhola, como nos mostra Aragão (1960, p.473).

Em Quito, deixa-se transparecer o Humboldt que zela pelo ideal da liberdade ${ }^{10}$ condenando a falta de imprensa livre, criticando o sistema de educação imposto às colônias, e até escrevendo folhetins com Carlos Montúfar, esse fuzilado posteriormente pelos espanhóis pelo símbolo que foi da emancipação colonial, como o foi Simon Bolívar (ibidem). É dessas experiências vividas que nascem os conteúdos das obras Ensaio do estado político do Reino da Nova Espanha e Ensaio político sobre a ilha de Cuba, onde combate fortemente o modelo de escravidão (Humboldt, 1822; Penna, 1960, p.680). Humboldt foi um homem de firmes convicções políticas liberais, defendendo sempre as aspirações dos grupos sociais oprimidos e as instituições livres (Capel, 2007, p.21). Dos manuscritos deixados por Humboldt, fica o reconhecimento na frase de Simon Bolívar: "Alexander Von Humboldt fez mais pela América que todos os seus conquistadores, ele é o verdadeiro descobridor da América".

Sobre essa questão, Aragão (1960, p.466-7) mostra um Humboldt de "sensível espírito humanístico", que percebe a maturidade política

10 Lembremos que Humboldt trocava correspondências com seu irmão, não menos ilustre, Guilherme de Humboldt, que além de ajudar a constituir a Universidade de Berlim, o sistema educacional prussiano e dar contribuições à linguística como sistema, foi um grande contribuinte dos ideais liberais, escrevendo $O s$ limites da ação do Estado, inspirando autores como John Stuart Mill. 
das colônias para se tornarem independentes. Essa faceta do naturalista, admirado com o "espírito de liberdade", pode ser considerada um tanto ingênua para a questão da América Espanhola e característica de um espírito humanístico idealista. Quem lhe tenta abrir os olhos é a figura do então presidente dos Estados Unidos, Thomas Jefferson, amigo e admirador de Humboldt. Na carta de Jefferson, de 1813, em resposta ao amigo Humboldt, consta o trecho que diz:

That they will throw off their European dependence I have no doubt; but in what kind of government their revolution will end I am not so certain. [...] And Mexico, where we learn from you that men of science are not wanting, may revolutionize itself under better auspices than the Southern provinces. These last, I fear, must end in military despotisms. The different casts of their inhabitants, their mutual hatreds and jealousies, their profound ignorance and bigotry, will be played off by cunning leaders, and each be made the instrument of enslaving others. But of all this you can best judge, for in truth we have little knowledge of them to be depended on, but through you. ${ }^{11}$

Os dois viriam a trocar uma série de correspondências, depois da extensão aos Estados Unidos da viagem de Humboldt a Cuba, e esse presentearia Jefferson com os resultados de suas pesquisas. Jefferson procura Humboldt até mesmo para auxiliar nas questões territoriais sobre os limites entre a Louisiana e a América Espanhola e sobre a etnia das populações que se poderia encontrar nessa região, bem como se existiam reservas minerais (Moheit, 1993, p.296).

11 Tradução dos autores: "Que eles vão sair de sua dependência europeia não tenho dúvidas, mas em que tipo de governo vai acabar a sua revolução não estou tão certo. [...] E o México, onde podemos aprender com você que os homens da ciência não estão querendo, pode revolucionar a si mesmo melhor do que as províncias do sul. Estes últimos, temo eu, devem terminar em despotismos militares. Os moldes diferentes dos seus habitantes, seus ódios e invejas mútuas, a sua profunda ignorância e intolerância, será a saída de líderes ardilosos, e cada um será o instrumento de escravizar os outros. Mas de tudo isso, você pode julgar melhor, pois na verdade temos pouco conhecimento com que podemos contar, mas através de você". 
Na América, Humboldt viria ainda a escalar o vulcão Chimborazo, realizando medições barométricas e experiências magnéticas e hidráulicas; faria observações astronômicas da passagem de Mercúrio sob o disco solar em Lima; observaria os satélites de Júpiter na aldeia de Jaen e, com medições lunares, corrigiria o mapa de La Condamine; catalogaria novas espécies e recolheria mais amostras mineralógicas; observaria as propriedades do guano e seu potencial econômico para a região; seria expectador das atividades do vulcão Cotopaxi; contemplaria as minas de Taxco e as montanhas de Nevada, as ruínas de Tula e tomaria contato com artefatos de civilizações pré-colombianas. Um dos ápices da viagem, em termos de descobertas científicas, foi a constatação da corrente do Pacífico Sul e os efeitos dela ocasionados.

\title{
Contribuições à constituição inicial da geografia como ramo científico
}

\author{
Eu o considero o cientista mais \\ importante que encontrei.
}

(Thomas Jefferson ${ }^{12}$ )

Na visão de La Blache (2001, p.5), temos um Humboldt preocupado com a coordenação e a classificação dos fatos, em que a conexão dos fatos é mais importante do que o fato em si, mesmo que esse seja algo novo. Ainda de acordo com La Blache (2001, p.5), a vertente mais ligada aos eventos da natureza "física", especialmente os estudos de botânica, transmitem à geografia o método de classificação das ciências naturais; contudo, isso não passa pela exclusão dos fatores humanos. Humboldt lança diversas bases para a geografia física, como em climatologia (termo provavelmente de sua autoria), botânica, orografia, oceanografia, geologia etc.; além disso, traz para a geografia fatores pouco explorados que agem so-

12 Estadista e filósofo político. Terceiro presidente dos Estados Unidos da América. 
bre as populações, como a estatística, a economia política, a pesquisa da origem da línguas e das migrações humanas (Aragão, 1960, p.465).

Para La Blache (2001), o modo de visão de Humboldt sempre busca constituir quadros gerais, em que "uma vez conhecida sua repartição terrestre, as próprias relações apresentar-se-ão ao espírito". É com essa conduta metódica, que, segundo La Blache (2001, p.5), "das observações de temperatura que era possível reunir, ele retirava o traçado das linhas isotermas". Exemplo singular é o livro Quadros da natureza. De acordo com La Blache (2001), "ele [Humboldt] se destaca por mobilizar os fatos, convertê-los em fórmulas correntes e em dados comparáveis entre si", sendo as sistematizações tipológicas e os quadros de observação, portanto, uma das grandes e influentes contribuições desse cientista à geografia. Contudo, éimportante levar em conta a consideração de Capel (2007, p.17) quanto a Humboldt buscar identificar e compreender as relações aparentemente desconexas dos fenômenos, cuja conexão não pode ser deduzida de um sistema taxonômico.

Em Humboldt já há uma perspectiva a formulação de leis terrestres e da interligação entre os diversos fenômenos (La Blache, 2001, p.6). O método comparativo que permite generalizações universais e a perspectiva histórica de evolução, em detrimento de uma natureza imutável, são as maiores contribuições de Humboldt para a ciência na visão de Capel (2007, p.17).

A Figura 1 é um dos trabalhos de Humboldt em conjunto com o botânico Joakim Frederik e integra o Physikalischer Atlas organizado por Heinrich Berghaus, o primeiro atlas a tratar a geografia física do mundo. Nela pode-se ter a noção do modo como o prussiano representava a conexão; no topo, constam os grandes elevados montanhosos, com suas respectivas zonas climáticas e latitudes, onde a vegetação aparece em níveis correlacionados com a altitude. O mapamundi traz as divisões fitogeográficas integrando-se perfeitamente com o gráfico estatístico das principais famílias de plantas à direita, que está dividido nas zonas fria, temperada e quente, mostrando a incidência de determinadas espécies em cada uma das zonas. 
De Schelling ficam em Humboldt características de uma natureza orgânica, ligada a alguns pressupostos vitalistas de impulso vital, que mantém no prussiano elementos do transcendental, apesar de sua forte relação com a empiria e a busca de explicação dos fenômenos de forma precisa (como vimos no caso do lago assombrado por espíritos na América, o qual Humboldt desmistifica). A parte estética, como observamos, pode ser atribuída a influências de Schiller, sendo possível atribuir também, de acordo com Vitte (2007), influências kantianas, demonstradas por Capel (2007, p.18), pela aceitação de Humboldt da distinção kantiana de "sistemas da natureza"e "descrições da natureza".

Ainda quanto ao movimento romântico, o convívio com Goethe foi de influências mútuas. Capel (2007, p.15) nos relata a visita que Humboldt fez a Goethe em 1794, quando tomou conhecimento de um projeto de novela intitulado "Sobre o Universo" com uma concepção harmônica da natureza.

A ciência humboldtiana, que se estendeu para além do próprio Humboldt, traz o empirismo baconiano, muito presente no modelo científico do século XIX, e a preocupação com a mensuração precisa dos fenômenos, para aí proceder em generalizações, formulando leis, trabalhando com o que o prussiano denominava "física terrestre". Humboldt coloca que sua ideia de física terrestre difere da tradicional história natural "descritiva", quando declara: "[traveling naturalists] have neglected to track the great and constant laws of nature manifested in the rapid flux of phenomena... and to trace the reciprocal interaction of the divided physical forces" ${ }^{13}$ (apud Jardine et al., 1996, p.289).

Humboldt não se considerava um explorador, mas sim um viajante científico, que media com precisão o que os exploradores tinham relatado incorretamente (Cannon, 1978, p.75). A real busca é a interconexão dos fenômenos naturais, sua forma de sistematização, é por meio de leis matemáticas, gráficos, tabelas e mapas (ibidem,

13 Tradução dos autores: "[viajantes naturalistas] têm negligenciado acompanhar as grandes e constantes leis da natureza manifestadas no fluxo rápido dos fenômenos... e traçar a interação recíproca das forças físicas divididas". 


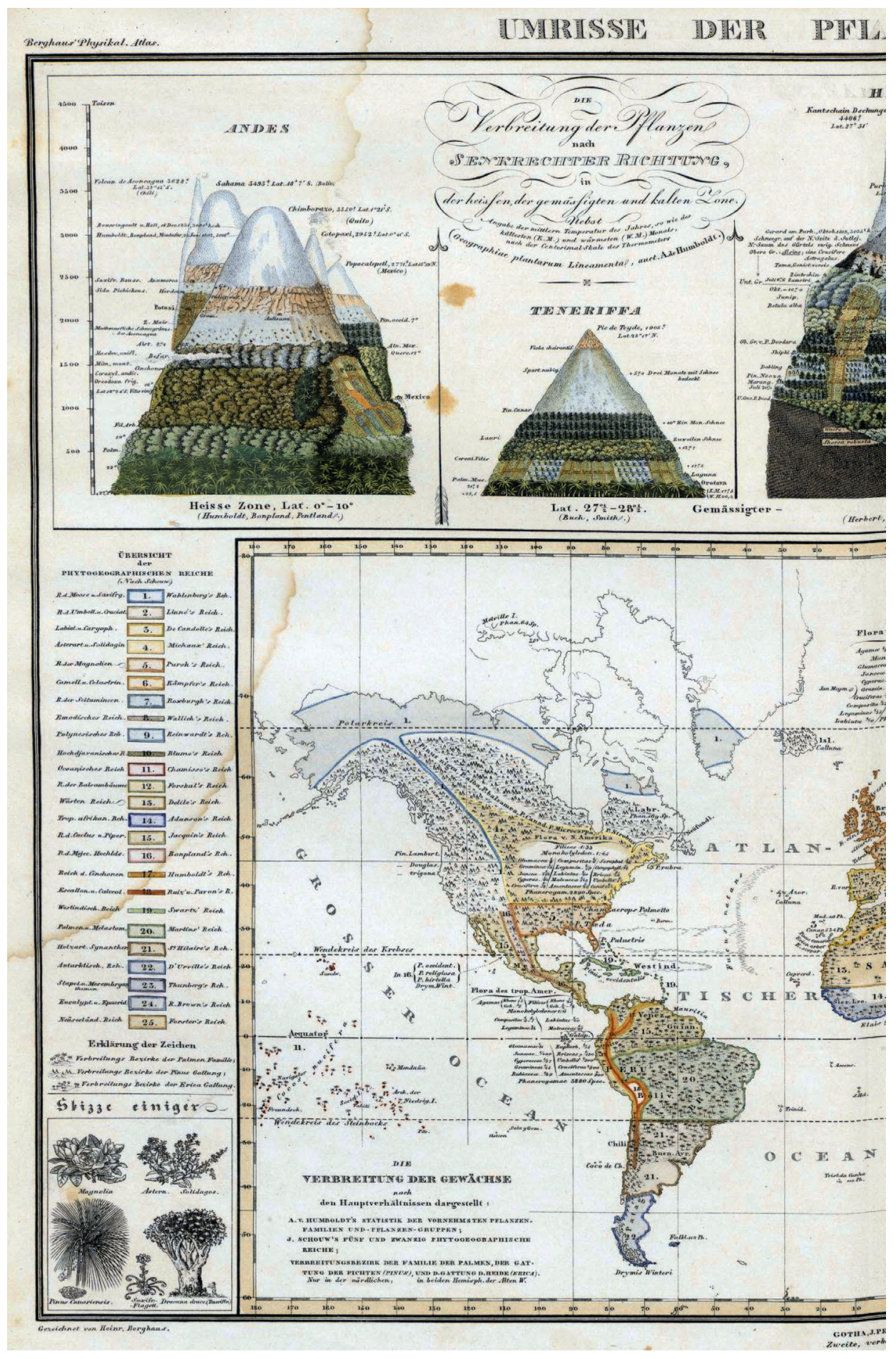

Figura 1 - Forma de representação clássica de Alexander Von Humboldt sobre conexões de fenômenos. Fonte: Physikalischer Atlas (Berghaus, 1845, p.259). 


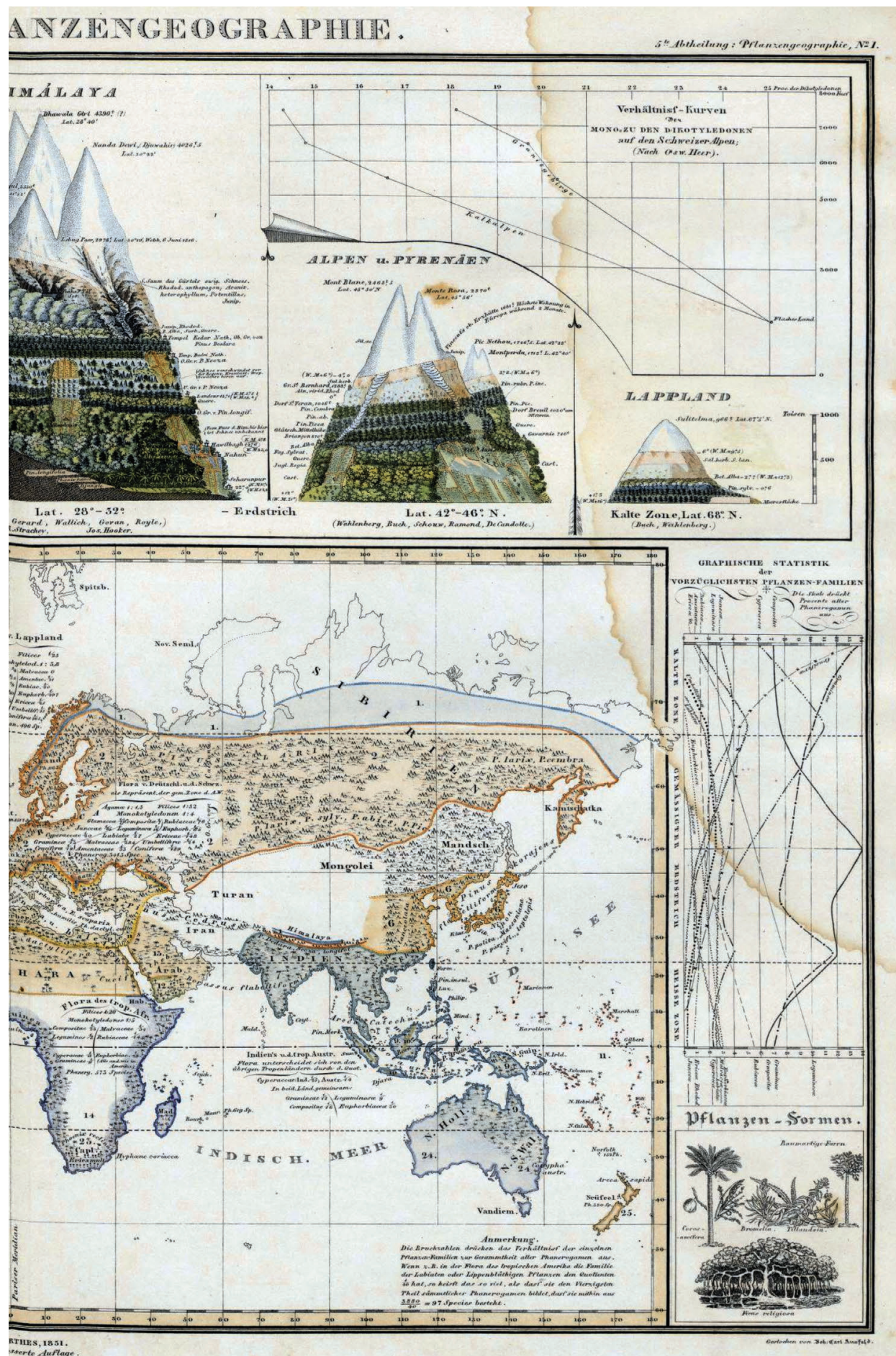


p.104-5). Para Capel (2007, p.15), existe fortemente em Humboldt a ideia de "harmonia", que, aliada à sua estada em Freiberg e aos seus estudos de Geognosia, provavelmente levou à ideia de "harmonia da natureza", e de que essa poderia ser empiricamente demonstrada. Esse é o grande projeto humboldtiano, um todo harmonioso, com partes intimamente relacionadas, e movido por forças internas, tudo passível de uma concepção idealista empiricamente demonstrável. A síntese dessas abordagens pode ser observada no Organograma 1, a seguir:

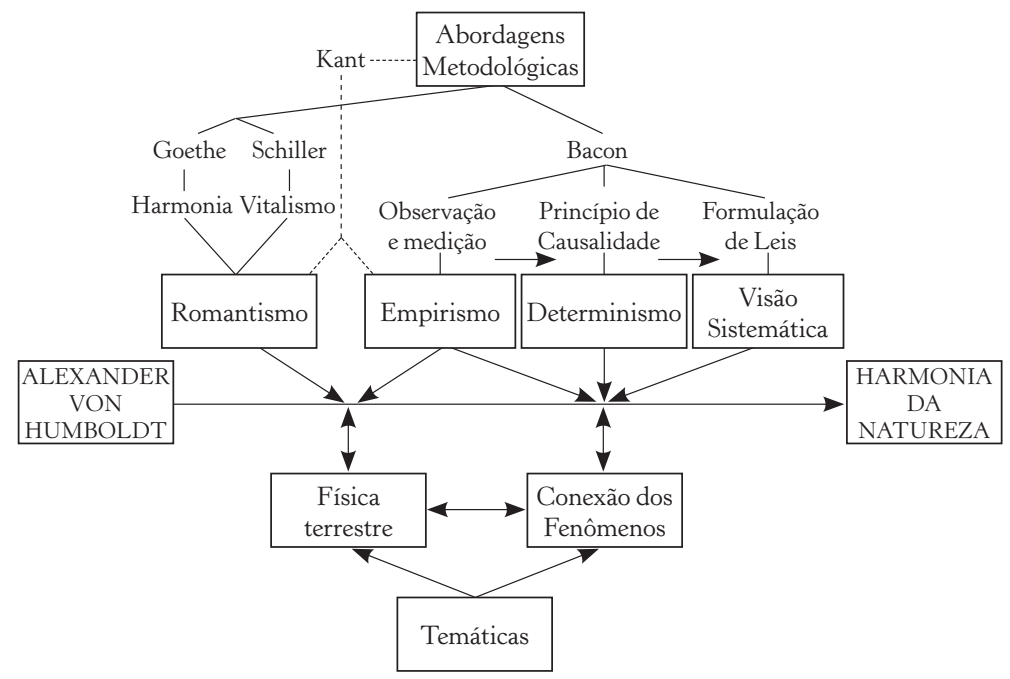

Organograma 1 - Síntese das abordagens teórico-metodológicas de Alexander Von Humboldt.

Organização: Danilo Piccoli Neto e Flamarion Dutra Alves.

Dentre inúmeras contribuições, como a melhor sistematização dos dados em cartas e mapas ou a idealização de perfis, está a genial ideia de isolinhas, amplamente difundidas em estudos climáticos e de geomorfologia, em que variáveis de mesma intensidade ou valor são conectadas por linhas, como no exemplo das curvas de nível. 
A ideia de isolinhas já é notada nos textos redigidos após a expedição à Ásia; frutos de avaliações geomagnéticas para fins mineralógicos, aliados a uma ideia de Halley sobre magnetismo (Capel, 2007, p.19), ganham destaque porém em Cosmos: "While the geography of plants and animals depends on these intricate relations of the distribution of sea and land, the configuration of the surface, and the direction of isothermal lines" ${ }^{14}$ (Humboldt, 1858, p.163); além dela, é possível observar a visão de complexidade da natureza, da interrelação dos fenômenos, características que vão permear os volumes dessa grandiosa obra compilatória, reconhecida por muitos como a maior realizada por Humboldt, na qual ele dedicaria empenho até o final de sua vida.

Paul Claval (2006, p.64-6) atenta para o fato de que a postura de Humboldt em não se ater somente à justaposição dos fenômenos, e sim na procura das propriedades globais dos conjuntos, aliado à sua base empírica de campo e um entendimento da diferenciação regional da Terra, partindo das reflexões de Kant, fez que, como naturalista, introduzisse um conceito base para a geografia moderna: o de meio.

A América pode ser considerada o grande laboratório "vivo", onde o extraordinário conhecimento teórico de Humboldt pode ser colocado na prática com grande vigor, gerando inúmeros trabalhos e descobertas que contribuíram para a constituição inicial do saber geográfico. O prussiano compilaria diversos dados gerando cartas, mapas, gráficos e esquemas, constituindo o que seria o primeiro atlas temático em que se caracteriza um continente que não fosse a Europa (Beck apud Kohlhepp, 2006, p.268), presente que foi dado ao amigo Thomas Jefferson.

A diversidade de economias e prosperidade dos locais visitados fez que Humboldt realizasse estudos regionais comparativos, reforçados também pela diversidade do relevo, do clima e da vegetação, como os presentes nas obras Aspects of Nature in Different Lands and

14 Tradução dos autores: "Embora a geografia das plantas e dos animais dependa destas intrincadas relações da distribuição de terra e mar, a configuração da superfície, e da direção das linhas isotérmicas". 
Different Climates (Humboldt, 1849) e Views of Nature: or Contemplations on the Sublime Phenomena of Creation (Humboldt, 1850). Na introdução da segunda obra, Humboldt nos diz: "I here present to the public a series of papers which originated in the presence of the noblest objects of nature, on the Ocean, in the forests of the Orinoco, in the Savannahs of Venezuela, and in the solitudes of the Peruvian and Mexican Mountais"15 (ibidem, p.IX). Quanto ao papel das regiões na obra de Humboldt, Capel (2007, p.20) nos chama a atenção para “quais são as raízes dessa valorização da 'fisionomia das regiões' é algo que está por se estudar".

Contribuiria sobremaneira para com a climatologia, dividindo as terras quentes, frias e temperadas, com base no conhecimento local dos habitantes da América; da viagem à Ásia viriam o "exame das causas das variações das isotermas em relação a sua disposição teórica segundo os paralelos e o papel das massas continentais e sua configuração topográfica" (Capel, 2007, p.19).

De visão arrojada, também notaria em um dos volumes a necessidade de uma ligação entre o Atlântico e o Pacífico, sendo o "pai intelectual” do canal do Panamá (Kohlhepp, 2006, p.268). Demais obras surgiriam em conluio com outros cientistas, como os volumes de Equinoctial Regions of America, traduzidas para o inglês em 1907, e escrita com o amigo Bonpland.

Humboldt trabalha no segundo volume de Cosmos de maneira inicial e próxima ao que viria a ser a geografia descritiva tradicional, e trabalha o elemento paisagem (landschafts) como retrato e ligação entre observador e objeto, por meio da arte (pintura). O estudo da paisagem em Cosmos é um desdobramento de suas preocupações iniciais com a ideia de natureza, que são primeiramente tratadas nas obras Aspects of Nature in Different Lands and Different Climates (Humboldt, 1849) e Views of Nature: or Contemplations on

15 Tradução dos autores: "eu aqui apresento para o público uma série de papéis que se originaram na presença dos objetos mais nobres da natureza, sobre o Oceano, nas florestas do Orenoco, nas savanas da Venezuela, e na solidão das montanhas do Peru e do México". 
the Sublime Phenomena of Creation (Humboldt, 1850), e que serão sistematizadas empiricamente após a viagem para a América em Personal Narrative of Travels to the Equinoctial Regions of America During the Years 1799-1804. Não poderia faltar em Cosmos a menção às técnicas para o cultivo de plantas, sendo a botânica verdadeira paixão do prussiano.

\section{Argumentações, críticas e considerações finais}

É ainda corrente o ideário de que Humboldt seria o grande expedicionário europeu que viria a descobrir o intocado continente americano. Essa ideia está na frase transcrita anteriormente aqui de Simon Bolívar, em que há de considerar uma particularidade histórica de conter uma ideia de libertação do governo da metrópole espanhola, mas também persiste na atualidade como em Aragão (1960, p.465): "podendo [Humboldt], pois, ser considerado o descobridor científico da América do Sul". Vale ressaltar que na América Espanhola já havia estudos, e que uma rede de pesquisa em universidades e centros especializados se constituiria logo no primeiro século de colonização, como a Universidade do México que data de 1551, fazendo parte de uma estratégia de ocupação planejada da metrópole europeia em conhecer sua colônia para dela poder extrair recursos.

Não se pode de maneira alguma descartar a genialidade de Humboldt em analisar o cenário que vivenciou, especialmente na América; do mesmo modo, não se podem descartar os homens de ciência que realizaram estudos antes da chegada do prussiano, a retomada do papel desses estudos e pesquisadores também se faz importante nos dias atuais, para caracterizar a grande diversidade que foi a constituição da América, que chegou até o presente de forma enviesada.

O quadro sinótico conhecido como Naturgemälde ou "Quadro físico dos Andes" é um exemplo destes impasses. Há quem considere ser esse estudo fruto de cópia dos estudos de Francisco José de Caldas, que já havia publicado croquis do gênero (Diener, 2001, p.109). No entanto, Humboldt, antes da viagem à América, já vinha 
pesquisando a relação entre altitude e vegetação em seus estudos dedicados à Geografia das plantas, mas a publicação do quadro só surgiu após a viagem. Não cabe julgar quem "copiou" quem, muitas ideias comuns fluem em diversas partes do globo sem o contato entre os idealizadores, mas cabe levar em consideração a perspectiva oferecida por La Blache (2001) de um Humboldt compilador, atento à classificação dos fatos.

O prussiano certamente soube absorver as ideias de Caldas, mas o hispano-americano não viu no prussiano o devido reconhecimento, percebido na introdução espanhola de Geografia das plantas, 1805, escrita pelo próprio Caldas, que deixa transparecer certo descontentamento: "respeitando as luzes, os vastos conhecimentos e os grandes talentos deste viajante extraordinário [Humboldt], porém respeitamos muito mais a verdade" (Diener, 2001, p.110).

Como grande pesquisador reconhecido e reverenciado mundialmente com trabalhos de impacto, seria incomum acreditar que Humboldt estaria a salvo de críticas e das análises posteriores da história sobre a ocorrência dos fatos em seu tempo. Atualmente no México, discute-se como se deve entender a obra de Humboldt em relação à América, total inovação ou gigantesca compilação? (ibidem, p.111). A obra Ensaio político sobre o Reino da Nova Espanha é discutida com extrema virulência (ibidem), sendo esse trabalho considerado pioneiro na área de geografia regional e política. Por todas as referências que vêm à luz nos estudos de Humboldt, muitas vezes de trabalhos relegados ao esquecimento, ou pouco valorizados, Diener (2001, p.112) exemplarmente coloca que "podemos afirmar que um dos grandes descobrimentos da sua viagem consistirá, precisamente, em dar a valoração que merece à literatura científica da Espanha e América Espanhola".

Mais uma vez se recorre à caracterização de La Blache (2001) quanto a Humboldt, e essa é possível compreender na própria visão que o prussiano assume quando seu colega Berghaus, organizando atlas mundial, coloca o nome de "Corrente de Humboldt", a corrente fria do Pacífico Sul a que o prussiano fez menção em suas obras. Humboldt vê na homenagem do colega atitude exagerada, já que 
ele apenas trouxe o fato à tona, pois tal corrente já era conhecida há trezentos anos por pescadores e que o jesuíta José de Acosta já havia mencionado tal fato de as águas serem frias em seus relatos, sua única contribuição "consiste em ter sido o primeiro em medir a temperatura desta corrente de água" (Minguet apud Diener, 2001, p.106).

Vemos nesse fato o prussiano em uma atitude completamente modesta, que se assemelha a um Humboldt catalogador, que ligou conhecimentos já existentes para propor uma ideia nova. Fato é que essa concepção é inteiramente inovadora, apesar de relatos e medições pretéritos. O grande marco de Humboldt é justamente criar uma teoria para o fato das formações atmosféricas não atingirem o continente e gerarem os desertos na parte oeste do continente sul-americano.

Se conferir seu nome ao fenômeno pode ser considerada uma homenagem extremada por Humboldt, e se esse vê com modéstia sua descoberta com base em relatos existentes, não se pode deixar de constatar que esse homem, preocupado em fazer grandes compilações, com um conhecimento enciclopédico, não se ateve apenas a reproduzir, mas mostrou articular tudo isso para propor teorias explicativas. Talvez aí resida uma das maiores contribuições de Humboldt, não em descobrir explicações para fenômenos, medir com precisão locais a partir de conhecimentos astronômicos, mas sim em coadunar compilações para ousar em propor algo novo. Reside aí, talvez, o espírito que caracteriza os grandes homens da ciência.

\section{Referências}

ARAGÃO, J. A. S. do. A vida e a obra de Humboldt. Revista Brasileira de Geografia, ano XXII, n.3, p.465-77, jul./set. 1960.

BERGHAUS, H. (Org.) Physikalischer Atlas. Gotha, 1845. Disponível em: $<$ http://pds.lib.harvard.edu/pds/view/8071752?n=1\&jp2Res $=0.125$ \&imagesize $=600$ \& rotation $=0>$.

BURHNS, K. Life of Alexander Von Humboldt compiled in commemoration of his birth. London: Langmans, 1873.

CANNON, S. F. Science in culture: the early Victorian Period. New York: Science History Publications, 1978. 
CAPEL, H. Filosofia e ciência na geografia contemporânea: uma introdução à geografia. Maringá: Massoni, 2007. v.1.

CLAVAL, P. História da geografia. Lisboa: Edições 70, 2006.

DARWIN, C. Collections of letters: letters addressed to professor Henslow. Disponível em: <www.darwin-online.org.uk/> Acesso em: 17 nov. 2009.

DIENER, P. A dívida americana de Alexandre de Humboldt. Territórios e Fronteiras, v. 2, n. 2, p.105-14, jul./dez. 2001.

HERRMANN, P. A conquista das Américas. São Paulo: Boa Leitura, 1960.

HUMBOLDT, A. Von. Ensayo politico sobre El Reino de La Nueva Espanã. Paris: Em Casa de Rosa, Gran Patio Del Palacio Real, 1822. t.I.

. Aspects of Nature in different lands and different climates. London: Longman, 1849.

. Views of Nature: or contemplations on the sublime phenomena of creation. London: Henry G. Bohn, 1850.

. COSMOS: A Sketch of the Physical Description of the Universe. London: Harper \& Brothers, 1858. v.1.

HUMBOLDT, A. Von; BONPLAND, A. Ideas para una geografia de las Plantas más un cuadro de los países tropicales. S. 1.: s. n., 1805.

Personal narrative of travels to the equinoctial regions of America during the years 1799-1804. London: George Bell \& Sons, 1907.

JARDINE, N. et al. Cultures of Natural History. Cambridge: Cambridge University Press, 1996.

JEFFERSON, T. Carta de Thomas Jefferson ao Barão von Humboldt, 1813. Disponível em: <http://memory.loc.gov/ammem/collections/jefferson_papers/index.html>. Acesso em: 17 nov. 2009.

KOHLHEPP, G. Descobertas científicas da expedição de Alexandre Von Humboldt na América Espanhola (1799-1804) sob ponto de vista geográfico. Revista de Biologia e Ciências da Terra, v.6, n.1, p.260-78, $2^{\circ}$ sem. 2006.

LA BLACHE, P. V. de. O princípio da geografia geral. GEOgraphia, ano III, n.6, jul./dez. 2001.

MOHEIT, U. (Ed.) Alexander von Humboldt: Briefe aus Amerika. 1799_ 1804. Berlin: Akademie Verlag, 1993.

PENNA, O. S. de O. Frederico Henrique Alexandre de Humboldt. Revista Brasileira de Geografia, ano XXII, n.4, p.678-703, out./dez. 1960.

VITTE, A. C. Influência da estética Kantiana na gênese da geografia física. In: VII ENCONTRO NACIONAL DA ANPEGE. Comunicações. Niterói: UFF, 2007. 


\title{
3 \\ O ESPAÇO EM Kant \\ E SUAS CONTRIBUIÇÕES NA DEFINIÇÃO DO CONCEITO DE REGIÃO
}

\author{
Juliana Emy Carvalho Tanaka*
}

\section{Introdução}

O pensamento geográfico vem sendo moldado desde a Antiguidade ao longo do tempo, sofrendo ora mutações e avanços sem precedentes, ora resgatando conceitos do passando e por vezes superando seus próprios saberes renovando-os de forma abrangente e ligando-os a outros sabres e outras ciências.

A condição humana desperta no homem desde os primórdios de sua existência uma teia complexa entre o ser e o espaço vivido por ele. Assim, a humanidade possui uma íntima ligação de desejo e necessidade de conhecer o seu espaço, bem como explorar outros, possibilitando o ajuste de conhecimentos vividos e adquiridos ao longo do tempo e refletindo, assim, as características não só temporais, mas também de uma dada sociedade e suas visões sobre o espaço.

Nessa relação complexa entre o tempo, o espaço e o homem, a geografia se molda e reflete a evolução da própria historia da humanidade, regendo não somente o pensamento, mas também as relações humanas, suas técnicas, suas construções no espaço e os

* Mestranda do Programa de Pós-Graduação em Geografia, Unesp - Rio Claro (SP). Bolsista CNPq. 
próprios desafios, possibilidades e limites impostos pelo avanço da ciência.

Assim, muitos geógrafos e pensadores do espaço geográfico surgiram para pensar o espaço. Durante a construção do Pensamento Geográfico, muitos pensadores e escolas foram vanguardistas em adequar novas tecnologias e novos saberes na disciplina geográfica, ou se organizaram para retomar problemáticas não resolvidas por escolas que os antecederam.

Este texto tem como objetivo discutir as contribuições e influências de Immanuel Kant (1724-1804) na geografia e, mais especificamente, na construção do conceito de região. Para tanto, serão abordadas as visões de Kant a respeito do espaço, bem como um breve comentário sobre sua relação com a geografia, quando em Königsberg ministrava a disciplina de Geografia Física. Posteriormente, serão tratadas as contribuições de Kant para a formação da definição do conceito de região e as principais ideias de Hettner e Hartshorne, que seguindo os passos de Kant formularam conceitos interessantes acerca do espaço e da região.

\section{Kant e a geografia}

Para muitos geógrafos, Immanuel Kant foi o primeiro acadêmico profissional de geografia a ser também um grande filósofo; já para os filósofos, Kant foi o primeiro filósofo a exercer uma carreira acadêmica, como tantos que vieram depois dele. Entretanto, neste texto trataremos das contribuições e visões de Kant na geografia, sem desconsiderar o que Schaefer (1977) chamou de excepcionalismo na Geografia ao se referir à introdução da disciplina numa universidade.

Kant ministrou, de 1756 a 1796, cursos de geografia física na Universidade de Königsberg, na qual, em 1802, publicaram-se notas de suas aulas que se referiam basicamente a uma intersecção entre a geografia e a história (Schaefer, 1977; Campos, 2001; Lencione, 1999).

Kant insere a geografia na estrutura da filosofia e da ciência, dividindo o conhecimento em três abordagens, segundo os objetos de 
estudo: reunir os fatos em grupos; estudá-los no tempo; e examiná-los no tempo (Broek apud Cidade, 2001). Na visão de Kant, a geografia seria um conhecimento empírico, porém sistematizaria e classificaria os fatos (Ferreira \& Simões apud Cidade, 2001).

Ainda de acordo com Cidade (2001), Kant uniu em síntese filosófica o que se tornaria o centro da filosofia moderna, elementos do racionalismo ${ }^{1}$ e do empirismo, ${ }^{2}$ fundando o criticismo.

Segundo Lencione (1999), é em Kant que se encontra a raiz da ideia de que o fundamento da geografia é o espaço. $O$ conhecimento pode ser classificado de acordo com similaridades, ou ainda de acordo com as suas divergências e distinções. A primeira classificação seria a lógica e a segunda, a física, daí a geografia ser atribuída por Kant como geografia física, divergindo do que conhecemos hoje por geografia física, ou seja, a que faz referência aos processos naturais.

\section{O espaço em Kant}

As considerações sobre as atribuições do espaço em geografia são comumente ligadas a Kant, pois é nele que se inicia a concepção de espaço como fundamento da disciplina, hoje tão amplamente discutido e sedimentado na ciência geográfica.

De acordo com Lencione (1999), algumas considerações devem ser realizadas a respeito da concepção de espaço na visão kantiana: (i) a associação permanente na obra de Kant sobre a indissociabilidade entre as condições naturais e a história humana, criando uma unidade do saber, uma vez que acreditava que não se pode conhecer

1 Racionalismo, para Magee (1999), assume a posição de que as preposições autoevidentes deduzidas pela razão são a única base de todo conhecimento. Descartes é considerado o primeiro racionalista e seu método influenciou filósofos, sobretudo Espinosa, Leibniz e Kant.

2 De acordo com Magee (1999), o empirismo sustenta que todo conhecimento deve ser derivado, ao fim e ao cabo, dos sentidos; todo conhecimento que realmente exista deve ser derivado da experiência. 
o homem se se ignorar o meio; (ii) o espaço como condição de toda a experiência dos objetos, e os objetos, assim como os homens, pertencem à natureza, mas são também astronômicos e geométricos, ou seja, nada pode ser representado sem o espaço.

A primeira consideração proposta por Lencione (1999) e citada aqui pode ser exemplificada por Reynaud (1975), quando diz que, "Para ele [Kant], a história é o relato dos fatos que se sucedem uma após outro (nacheinander) no tempo, enquanto a geografia é a apresentação dos fenômenos que se encontram um do lado do outro (nebeneinander) no espaço".

Quanto a distinção que Kant faz de geografia e história, escreveu:

A história e a geografia poderiam ser denominadas, por assim dizer, como uma descrição, com a diferença de que a primeira é uma descrição segundo o tempo e a segunda uma descrição segundo o espaço. Deste modo, a história e a geografia aumentam nosso conhecimento com respeito ao tempo e ao espaço [...]. A história, por conseguinte, difere da geografia somente com respeito ao tempo e ao espaço. (apud Campos, 2001, p.18)

Para Kant, a indissociabilidade entre o homem e o meio advém de uma linha de pensamento inaugurada por Locke [1632-1704], sob a qual tudo que aprendemos advém por meio dos nossos sentidos corporais. Assim, para Kant, de um lado está tudo que existe independentemente de nós e de nossa capacidade de experiência, e de outro está o que temos meios de experimentar. Portanto, o meio no qual se dão nossas experiências é característico de como nós seres humanos o percebemos e o entendemos. (Magee, 1999).

Daí Lencione (1999) mencionar a unicidade do saber, uma vez que meio e homem se fundem. Nessa perspectiva, os objetos materiais existem numa dada estrutura espaço-temporal, de modo que os seres humanos não conseguem conceber nenhum objeto real que não exista no espaço, bem como espaço e tempo são formas de nossa sensibilidade, sem as quais não conseguiríamos perceber ou aprender o mundo (Magee, 1999). Nas palavras de Kant (2005): 
O conceito de espaço não é abstraído de sensações externas. Pois não de pode conceber algo como posto exterior a mim a não ser representando-o como em lugar diverso daquele em que eu próprio estou, nem as coisas como exteriores umas às outras a não ser colocando-as em lugares diversos do espaço.

O espaço como condição de toda a experiência dos objetos, presente na obra kantiana, refere-se à ideia de que não existe objeto que não se insira no espaço, sobre essa questão, Kant (2005) diz que:

Assim, o espaço é um princípio formal do mundo sensível absolutamente primeiro, não só porque pelo conceito dele os objetos do universo podem ser fenômenos, mas, sobretudo, pela razão de que por essência é único, abrangendo de absolutamente tudo o que é sensível eternamente; constitui, por isso, o princípio da universalidade, isto é, de um todo que não pode ser parte de outro.

Assim, Kant contrapõe as concepções de espaço vigentes até então, especialmente as ideias de seu contemporâneo, Ritter, no qual o espaço determinaria os fenômenos, partindo Kant a defender a ideia de que o espaço é condição para um dado fenômeno. Portanto, utilizando-se da reflexão proposta por Lencione (1999), "o espaço geográfico, a relação entre o geral e o particular, temas tão caros à geografia, já aparecem sistematizados no pensamento de Kant".

Em Escritos pré-críticos, Kant (2005) ensaia sobre o espaço, possuindo como arcabouço teórico-filosófico cinco pilares centrais acerca do que considera espaço: (i) "O conceito de espaço não é abstraído de sensações externas"; (ii) "O conceito de espaço é representação singular que compreende tudo em si"; (iii) "O conceito de espaço é, assim, intuição pura, visto que é conceito singular"; (iv) "O espaço não é algo de objetivo e real, nem substancia, nem acidente, nem relação, mas é subjetivo e ideal"; (v) "Ainda que o conceito de espaço, como o conceito de algum ente ou de propriedade objetivos e reais, seja imaginário, no entanto, relativamente a tudo que é sensível, não só é muito verdadeiro, mas também é o fundamento de toda verdade na sensibilidade externa". 
Por meio desses cinco pilares sobre o pensamento kantiano a respeito do espaço pode-se atribuir uma constante vinculação do sujeito com o espaço, na qual compreender o primeiro só se dá se compreendendo-se o segundo, pois é o sujeito que carrega em si a percepção do espaço.

Quanto ao conceito de espaço ser uma representação singular, Kant (2005) ressalta a importância de uma visão integral, ou seja, a ideia do todo em contraposição à supervalorização das partes, sob a qual escreve que "O que chamamos diversos espaços não são senão partes de um mesmo espaço imenso, as quais se correlacionam por certa posição, e não podemos conceber um pé cúbico senão como delimitado por todos os lados por um espaço circundante".

A singularidade do conceito de espaço em Kant é, pois, fundamentada nas sensações externas, ou seja, o que Kant chama de intuição pura. É nesse ponto que Kant se volta para o empirismo e destaca o papel da geometria na qual revela evidências nas demonstrações de um dado objeto no espaço, porém fazendo parte e contendo em si intuições puras. Em suas palavras:

Por isso, a geometria serve-se de princípios que não são apenas indubitáveis e discursivos, mas que caem sob o olhar da mente, e a evidência nas demonstrações (que é a clareza de um conhecimento certo, na medida em que se assemelha ao conhecimento dos sentidos) é nela não somente a maior, mas também a única que se dá nas ciências puras, e é o modelo e o meio de toda evidência nas outras ciências, porque, visto que a geometria contempla relações do espaço, cujo conceito contém em si a própria forma de intuição sensível, nada do que é percebido pelo sentido externo pode ser claro e perspícuo senão por intermédio dessa mesma intuição, de cuja contemplação aquela ciência se ocupa. (Kant, 2005)

Na concepção de que o espaço não é algo real e objetivo, Kant (2005) afirma ser o espaço "subjetivo e ideal e como que um esquema proveniente da natureza da mente segundo uma lei estável para coordenar entre si absolutamente tudo que é sentido externamente"; 
complementando, assim, o princípio de universalidade, uma vez que o espaço abrange tudo que é sensível e que as partes não devem receber maior relevância do que o todo.

\section{A contribuição de Kant para a definição do conceito de região}

A contribuição de Kant para o conceito de região adveio especial e primordialmente nas suas afirmações a respeito da organização do conhecimento humano. Segundo Botelho (1987), para Kant as ciências que são baseadas na observação se classificam em quatro grandes categorias: (i) as Ciências substantivas, que são aquelas que agrupam coisas ou conhecimento que são semelhantes por possuírem uma origem em comum, como as ciências naturais e as sociais; (ii) Ciências sistemáticas ou Tópicas, que são aquelas que estudam fatos ou coisas partindo de um ponto de vista, podendo ser diferente, como a botânica e a zoologia; (iii) Ciências cronológicas, sendo aquelas que agrupam coisas e acontecimentos por ordem de ocorrência, ou sucessão no tempo, como a historia, a paleontologia; (iv) Ciências corológicas, como aquelas que agrupam coisas ou acontecimentos que ocorrem na mesma parte da superfície terrestre, ou seja, que estudam a sucessão de fatos na superfície da Terra, como a geografia.

A partir do princípio corológico, Kant atribui à geografia uma nova essência metodológica de agrupamento de "coisas e acontecimentos", o que podemos chamar de espaço regional, procurando esse método manter certa unidade à ciência geográfica, dando-lhe um método próprio e divergente do pensamento positivista. De acordo com o princípio corológico da geografia, na visão kantiana, é que alguns geógrafos que seguiram suas ideias irão caracterizar na geografia dois tipos fundamentais de ciência: a idiográfica e a nomotética, que seriam:

As idiográficas, ciências do homem, são descritivas, tratam de fatos não repetitivos, não reprodutíveis e, portanto, sem aspectos 
regulares que possam fundamentar leis ou normas gerais. Estes fatos só podem ser compreendidos a partir do contexto particular que os gerou, não podem ser explicados, mas somente compreendidos à luz de suas particularidades.

A ciência nomotética, ao contrário, procura nos fatos aquilo queé regular, geral e comum, estabelece assim modelos abstratos que podem antecipar resultados à partir do conhecimento das variáveis fundamentais que definem um fato ou fenômeno. (Gomes, 1995, p.58)

Sobre o método regional que o princípio corológico apresentou à geografia, Schaefer (1977) expõe que uma região contém uma combinação única de aspectos e fenômenos. Cabe ao geógrafo, do ponto de vista do método regional, descrever a região de forma minuciosa e em seguida colher informações sobre a distribuição espacial dos indivíduos de acordo com classes. Porém, essa primeira etapa se constitui como mera descrição, cabendo ao cientista social descobrir as relações entre as classes e os indivíduos, dando à área de estudo um caráter único que a transformaria em região.

Já Gomes (1995) tece a seguinte reflexão sobre o método regional baseado no princípio corológico da geografia, "o método regional, ou seja, o ponto de vista da Geografia, de procurar na distribuição espacial dos fenômenos a caracterização de unidades regionais, é a particularidade que identifica e diferencia a Geografia das demais ciências".

Para Campos (2001), a geografia, na visão de Kant, seria uma ciência empírica e ideográfica, concebida de modo sintético (que trabalhava com dados de outras ciências), além de descritiva (pois enumerava e classificava fenômenos), tendo como objetivo estabelecer uma visão de conjunto da superfície terrestre. Sobre a organização das experiências em um todo sistemático, de acordo com Tatham (apud Campos, 2001), Kant expõe:

Assim como, antes de construir uma casa se deve ter a concepção do conjunto de onde se formarão as várias partes, tornase necessário que, antes de iniciar o estudo do mundo, tenha-se a 
concepção do todo, um sistema arquitetônico de onde os diversos detalhes serão formados. A geografia física fornece tal sistema para o estudo da natureza. O conhecimento do mundo requer mais do que apenas vê-lo. Aquele que deseja captar o que for útil de suas viagens, deve previamente elaborar um plano de viagem, e não apenas observar o mundo segundo a percepção sensorial objetiva.

Assim, muitos geógrafos retomaram as ideias de Kant e o princípio corológico para a apresentação da geografia e sua diferenciação das demais ciências, sempre retomando e reformulando a questão da região, baseada no método regional. Destacam-se os trabalhos de A. Hettner, R. Hartshorne, Dithley, D. Harvey, entre outros.

No final do século XIX, na Alemanha, Hettner foi um dos maiores defensores de uma geografia que utilizasse como escopo o método regional como síntese de seu trabalho. Retomando alguns pontos das ideias de Kant, acreditava que os métodos das ciências humanas não poderiam se comparar àqueles propostos pelo positivismo clássico (aplicados à física e à matemática) (Gomes, 1995). Segundo Mendoza (apud Gomes, 1995), para Hettner a geografia era idiográfica, visto que seu objeto é o espaço terrestre e esse, por sua vez, é diferenciado, não regular e único em cada paisagem. A geografia de Hettner seria então "a ciência da superfície terrestre segundo suas diferenças regionais".

Ainda sobre o caráter idiográfico da geografia de Hettner, Campos (2001) expõe que, após a releitura de Kant, Hettner retoma as concepções de ciência idiográfica para a chamada geografia regional, ou seja, para os estudos das regiões que podem ser únicas e que integram num mesmo espaço diversos elementos. Para ele, a geografia possuía uma característica corológica, firmando em Die Geographie de 1927, que "tem como objetivo conhecer o caráter dos países ou regiões, mediante a compreensão da coexistência dos diversos reinos da natureza nas suas diferentes formas" (Ferreira \& Simões apud Campos, 2001). Hettner introduziu a geografia no estudo da diferenciação de áreas que será retomada posteriormente pelo norteamericano Richard Hartshorne. 
Para Hettner, a geografia espacial ou regional "deveria considerar as unidades espaciais, as régios ou os lugares, um de cada vez, sendo ela o estudo das diferentes áreas ou lugares e de suas relações". Afirmando que "a visão geográfica detém ora em um único lugar, ora considera a superfície da terra, para comparar os lugares entre si; mas esta sempre voltada para as diferenças dos espaços terrestres" (Amorim Filho apud Campos, 2001).

Outro geógrafo a pensar a região a partir de uma visão kantiana é o norte-americano Richard Hartshorne. Seguindo o princípio de diferenciação de áreas de Hettner, induz ao conhecimento regional, que constituirá uma das preocupações centrais da geografia, segundo sua visão. Tal ideia foi alcançada por meio da divulgação de Hartshorne em The Nature of Geography (Gomes, 1995).

Para Gomes (1995), "o elemento fundamental retido por Hartshorne é a classificação das ciências propostas por Kant”. Hartshorne procurou na sua obra diferenciar dois tipos de geografia, chamadas de geral ou sistemática (que seriam as ciências teóricas ao lado das naturais); e as ciências empíricas e regionais (aquelas análogas à história). A geografia geral teria uma metodologia analítica, objetiva e normativa; e a geografia regional comportaria o empirismo e a descrição, tendo por objetivo final a busca por um espírito de síntese.

Para Hartshorne (apud Gomes, 1995), "a região não é uma realidade evidente, dada a qual caberia apenas ao geógrafo descrever. A região é um produto fundamental, uma forma de ver o espaço que coloca em evidencia os fundamentos da organização diferenciada do espaço". Hartshorne foi amplamente criticado por Schaefer, que segundo Gomes (1995) tentava descobrir as origens do excepcionalismo na geografia. Segundo esse autor, o que Kant trouxe a geografia é negativo, pois ele a exclui da lista das ciências que devem buscar explicações objetivas.

Muitos autores, entretanto, mesmo não seguindo a visão kantiana, admitem a primazia de Kant sobre a introdução de muitas discussões, como "os geógrafos que verdadeiramente examinaram a questão da filiação kantiana da geografia são pouco numerosos, mas certo consenso existe no que diz respeito à primazia de Kant, 
considerada como quase evidente" (Gomes, 1995, p.138); ou um contemporâneo de Schaefer que diz ser "uma grande felicidade ter nas fileiras da geografia americana moderna o erudito Richard Hartshorne, que ponderou o significado de tradição dos estudos de área com uma sutileza com a quais poucas pessoas poderiam competir" (Pattison, 1977).

A pluralidade de conceitos e de visões acerca da região se mostra benéfica, uma vez que o espaço geográfico não se constitui como estático e acabado, estando sempre numa permanente dinâmica. Mesmo no período atual da ciência geográfica, a região continua como uma das pautas mais importantes nas discussões geográficas, sendo inegável a contribuição de Kant para a constituição do arcabouço teórico para a definição do conceito de região. As ideias de Kant, especialmente no que tange a categoria da geografia como uma ciência corológica, evoluiu muito ao longo do tempo, sendo utilizada por muitos geógrafos. Algumas de suas ideias permanecem até hoje; outras, entretanto, foram transformadas ou superadas.

O debate acerca da região é um assunto atual, portanto a visão kantiana contribui pela sua gênese e por sua introdução da definição do conceito de região em nossa ciência. Cabendo, assim, aos geógrafos contemporâneos a reflexão sobre a região no mundo globalizado, no qual os limites são cada vez mais complexos de ser visualizados.

\section{Considerações finais}

Pudemos mostrar algumas contribuições de Kant para a ciência geográfica, uma vez que é a ele atribuída a introdução da discussão do espaço e da região em geografia. Portanto, um dos objetos de investigação tão amplamente estudados hoje em geografia remonta à vanguarda de Immanuel Kant, já no século XVIII. Para Kant, o espaço é condição para as experiências dos objetos e uma representação necessária a toda experiência externa, por meio da intuição (do contato imediato com o objeto) e da representação (advinda da singularidade do objeto). Nada pode ser representado sem o espaço. 
Assim, Kant supera as ideias de Humboldt, Ritter e Ratzel, para o quais o espaço, simplificadamente, consistia em se estudar e analisar respectivamente a forma, as funções e a estrutura.

Além dessa afirmação, Kant introduziu a importância da história para entendermos determinadas situações e fenômenos, bem como a importância do espaço na geografia. Assim, conhecer o homem só é possível se conhecermos o seu meio. Kant também dividiu as ciências, caracterizando a geografia como uma ciência corológica; esse aspecto foi fundamental em trabalhos posteriores, para que geógrafos aparecessem e retomassem essa ideia, a fim de construir os primeiros conceitos acerca de região.

O princípio de diferenciação entre áreas foi o mais difundido, no qual destacamos as ideias de Hettner, e posteriormente Hartshorne. Sob esse ponto de vista, a região é um produto da organização diferenciada no espaço, retomando as ideias classificatórias de Kant em agrupar os fenômenos, mas agora com a introdução do ponto de vista da região.

Hoje, a questão da região é mais complexa, pois é difícil delimitar áreas, uma vez que nos encontramos em um mundo globalizado e no qual as fronteiras são cada vez mais simbólicas do que reais. Da questão da região, introduzida por Kant, derivaram muitos outros questionamentos e desdobramentos. Criaram-se os conceitos de regionalismos, de regionalizações, dos territórios, entre outros, que contribuem para o debate da ciência e da construção da geografia.

\section{Referências}

ANDRADE, M. C. de. Caminhos e descaminhos da geografia. Campinas: Papirus, 1992.

BOTELHO C. L. A filosofia e o processo evolutivo da geografia. Ceará: Imprensa Universitária da Universidade Federal do Ceará, 1987.

CAMPOS, R. de. A Escola Alemã de Geografia. Geografia, Rio Claro, v.26, n.2, p.9-67, 2001.

DAVIES, W. K. D. Teoria, ciência e geografia. Boletim de Geografia Teorética, Rio Claro, v.7, n.13, p.85-99, 1977. 
GOLDMANN. L. Origem da dialética-A comunidade humana e o universo em Kant. Trad. Haroldo Santiago. Rio de Janeiro: Paz e Terra, 1967.

GOMES, P. C. da C. O conceito de região e a sua discussão. In: CASTRO, I. E. de et al. (Org.) Geografia: conceitos e temas. Rio de Janeiro: Bertrand Brasil, 1995. Cap. 2, p.49-76.

Geografia e modernidade. Rio de Janeiro: Bertrand Brasil, 1996.

HARTSHORNE, R. Questões sobre a natureza da geografia. Trad. Thomaz N. Neto. Rio de Janeiro: Instituto Pan-Americano de Geografia e História, 1969.

KANT, I. Pré-escritos. Trad. Jair Barboza et al. São Paulo: Editora Unesp, 2005.

Crítica a razão pura. Lisboa: Calouste Gulbenkian, 2008.

LENCIONE, S. Região e geografia. São Paulo: Edusp, 1999.

MAGEE, B. História da filosofia. São Paulo: Loyola, 1999.

PATTISON, W. D. As quatro tradições da geografia. Boletim de Geografia Teorética, Rio Claro, v.7, n.13, p.101-10, 1977.

REYNAUD, A. A noção de espaço em geografia. Boletim de Geografia Teorética, Rio Claro, v.5, n.9-10, p.17-32, 1975.

SCHAEFER, F. K. O excepcionalismo na geografia: um estudo metodológico. Boletim de Geografia Teorética, Rio Claro, v.7, n.13, p.5-37, 1977. 



\title{
4 \\ A geOgRAFIA ESCOLAR NO BRASIL DE 1549 ATÉ A DÉCADA DE 1960
}

\author{
Thiago Tavares de Souza* \\ João Pedro Pezzato**
}

\section{Introdução}

Estudos a respeito da constituição da geografia como disciplina escolar e da história de sua institucionalização como área do conhecimento, a partir do século XIX, são raros no Brasil. São também escassos trabalhos de caráter epistemológico a respeito da geografia produzida no país.

E no que se refere especificamente ao ensino da geografia, o problema aumenta. Há uma confusão generalizada a respeito da relação entre a produção da universidade, ou seja, das pesquisas realizadas no campo da geografia, e o trabalho dos professores de geografia do Ensino Básico. São pouquíssimos os centros que desenvolvem pesquisas no campo do ensino da geografia.

No que diz respeito aos conteúdos de ensino, é generalizada a concepção de que a escola trabalha com a simplificação da ciência de referência, produzida nas universidades, nos institutos e demais

* Mestrando do Programa de Pós-Graduação em Geografia, Unesp - Rio Claro (SP), e professor da Educação Básica.

** Professor doutor do Programa de Pós-Graduação em Geografia, Unesp - Rio Claro (SP). 
instituições de pesquisa. Nessa perspectiva, entre os saberes escolares e os conhecimentos produzidos pelos cientistas há, apenas, uma diferença de grau.

Acreditamos que no Brasil seja necessário o desenvolvimento do campo de pesquisa a respeito do ensino de geografia para que seja ampliada a discussão dos fenômenos relativos à geografia escolar.

Nesse contexto, estamos desenvolvendo uma pesquisa cujo enfoque é a trajetória da geografia na escola básica. Na perspectiva da pesquisa qualitativa, faremos o registro de depoimentos de professores que trabalharam com o ensino de geografia a partir da década de 1960, no Estado de São Paulo, Brasil. Com a coleta de dados em andamento, o presente texto aborda a problemática a partir da análise de documentos escritos: pesquisa da literatura e análise de documentos oficiais, como propostas curriculares e a legislação.

$\mathrm{Na}$ perspectiva do estudo da história das disciplinas escolares, num primeiro momento, enfatizamos a construção dos currículos; posteriormente, apresentamos uma proposta de periodização da geografia escolar em três fases.

\section{A constituição do currículo: considerando a história das disciplinas escolares}

Desenvolvendo trabalhos no campo de estudo da história das disciplinas escolares, Chervel (1990) busca investigar as finalidades do ensino escolar e esclarecer por que a escola ensina o que ensina. Sua abordagem privilegia a disciplina escolar como produtora de conhecimento.

Para o autor, o papel da escola não se limita ao exercício das disciplinas escolares. Essas constituem uma parte da educação escolar. Considera, ainda, que as finalidades da educação escolar não estão forçosamente inscritas nos textos, mas, de certa forma, colocadas em posição antagônica entre o lado da lei, da prescrição institucional, e o das práticas concretas, desenvolvidas no cotidiano. Ademais, o autor coloca que a escola possui liberdade de manobra para definir 
sua pedagogia e seu conteúdo. Advoga que os conteúdos de ensino não são apenas expressão das ciências de referência, como muitas vezes o senso comum e a própria escola pregam, mas que esses foram historicamente criados pela própria escola, "na escola e para a escola." (ibidem, p.181).

Entre suas formulações, Chervel destaca a importância de pesquisas que se propõem a descrever as práticas desenvolvidas no interior da escola. Trata, assim, de imprimir a relevância da investigação dos fatos internos à escola, pois esses se constituem como principais elementos explicativos do funcionamento das instituições de ensino.

A disciplina escolar compreende a articulação de saberes de referência e métodos pedagógicos (ibidem, p.181). Na escola, ela se consolida mediante um processo de associação entre o currículo explícito e formal e o currículo oculto e informal. Tal combinação ocorre no interior das escolas e das salas de aula, desenvolvendo-se, em cada uma delas, de forma singular.

Já o currículo oculto e informal, ou seja, o currículo real, compreende um complexo de práticas e símbolos criados pela escola, como a determinação dos arranjos de espaço físico definidos em seu interior, na instituição de rituais e normas de conduta adotados em cada estabelecimento.

O currículo escrito, como denomina Goodson (1991), é o testemunho visível dos fundamentos racionais selecionados pela retórica que é legitimada pela escolarização. Ele expõe as intenções básicas da escolarização materializada pelas estruturas institucionais. Como explicita o autor: "o currículo escrito nos proporciona um testemunho, uma fonte documental, um mapa variável do terreno: é também um dos melhores guias oficiais sobre a estrutura institucionalizada da escolarização" (ibidem, p.10).

Segundo o autor, há amplas variações entre o que separa o currículo escrito (e uma teoria curricular) e a prática na sala de aula. Contudo, afirma que a construção do currículo escrito formal pode estabelecer parâmetros significativamente importantes para a realização do currículo interativo da sala de aula. Além disso, o 
processo de escolha dos conteúdos é influenciado pelo momento histórico, como pode ser explicado por esta citação de Fourquin (1992, p.30):

de acordo com as épocas, as sociedades, os níveis de estudo, as clientelas escolares, as ideologias pedagógicas, o sistema de relações de forças entre os grupos que buscam controlar as transmissões educacionais, não são os mesmos aspectos, os mesmos componentes da herança que dão lugar à referência, à interpretação ou à transmissão no contexto dos programas escolares. [...] nos ensinos onde o passado não se torna o objeto de uma atenção ou uma tematização explícita (como é o caso, mais frequentemente, nas disciplinas científicas ou técnicas, onde o saber se constrói por uma superação contínua das aquisições e por uma luta permanente contra a obsolescência), o passado pode permanecer presente, mas sob forma implícita ou latente, incorporado em habitus intelectuais, em modelos de pensamento, em procedimentos operatórios considerados como naturais e evidentes, em tradições pedagógicas. Assim, a dimensão temporal da cultura pode se revestir no interior do currículo de toda a espécie de graus e de modulações.

Segundo Fourquin, além dos aspectos relacionados à herança do passado, os fatores conjunturais também merecem ser sublinhados, dado que exercem significativo papel no processo seletivo de constituição do currículo escolar. Nos termos do autor, a seleção cultural escolar

não se exerce unicamente em relação a uma herança do passado, mas incide também sobre o presente, sobre aquilo que constitui num momento dado da cultura (no sentido antropológico assim como no do intelectual do termo) de uma sociedade, isto é, o conjunto dos saberes, das representações, das maneiras de viver que têm curso no interior desta sociedade e são suscetíveis, por isso, de dar lugar a processos (intencionais ou não) de transmissão e de aprendizagem. (ibidem,p.31) 
Nesse contexto, investigar a relação existente entre os fatores internos e externos na determinação do funcionamento da escola brasileira constitui amplo campo a ser explorado pelas pesquisas.

Ao tratar do conhecimento da história da geografia como disciplina escolar, visamos contribuir para o esclarecimento da articulação entre a ciência de referência e os métodos de ensino. Essa articulação ocorre em situações de ensino e é permeada pela elaboração e re-elaboração proveniente do conhecimento do senso comum, de representações de professores e alunos, no contexto dinâmico da sala de aula.

\section{Uma periodização possível: trajetória da geografia escolar no Brasil}

Para iniciar nossa discussão sobre a trajetória da geografia escolar, apresentamos este capítulo que, baseado numa extensa revisão bibliográfica, busca estabelecer uma periodização para o ensino da geografia escolar.

Inicialmente elaboraríamos duas narrativas paralelas, uma sobre a geografia escolar e outra sobre a acadêmica. Nosso objetivo era o de que ficassem evidentes os momentos de integração e afastamento entre as duas correntes. Porém, o contato com a bibliografia nos mostrou a necessidade de outra narrativa, que tratasse das ideias pedagógicas no Brasil. Essa forma nos pareceu mais pertinente para explicar o relacionamento entre as duas modalidades de conhecimento da geografia.

Admitimos que o caráter sintético deste trabalho possa incorrer a simplificações demasiadas e omissão de informações. Entretanto, nos arriscamos nessa empreitada por considerarmos relevante uma visão global do tema para que o leitor consiga entender, mesmo que superficialmente, todo o processo que trouxe a pluralidade de métodos e concepções contemporâneos.

Com isso, trazemos uma narrativa organizada em três períodos, explicados no Quadro 1. 
Quadro 1 - Quadro de periodização da trajetória da geografia escolar no Brasil

\begin{tabular}{|l|l|}
\hline Período & Justificativa da divisão \\
\hline $1549-1920$ & $\begin{array}{l}\text { Inicia-se com a vinda dos jesuítas ao Brasil, tendo } \\
\text { como um dos objetivos a educação dos colonos } \\
\text { e índios, e termina na década de 1920, período de } \\
\text { inserção da Geografia nos currículos escolares, na } \\
\text { Universidade e do movimento Escola Nova. }\end{array}$ \\
\hline $1920-\mathbf{1 9 6 0}$ & $\begin{array}{l}\text { Inicia-se com as mudanças citadas que foram } \\
\text { aprofundadas nesse período e termina com a } \\
\text { emergência de novos paradigmas, como a geografia } \\
\text { teorética, a educação tecnicista da nova LDB e o } \\
\text { esvaziamento politico da geografia escolar. }\end{array}$ \\
\hline $1960-$ até a atualidade \\
(início do XXI) & $\begin{array}{l}\text { Período de enfoque do nosso trabalho, tanto pelas } \\
\text { mudanças nas geografias acadêmica e escolar, nos } \\
\text { métodos de ensino e em razão da promulgação } \\
\text { da LDB quanto por ser o único período do qual } \\
\text { conseguiremos registros de depoimentos orais. }\end{array}$ \\
\hline
\end{tabular}

Dessa forma, pretendemos abarcar de uma forma geral a geografia escolar, desde os vultos longínquos do primeiro período, passando por uma análise mais elaborada no segundo e coroando com nosso período de enfoque, o qual será contemplado com uma análise mais ampla. Dividida em duas partes, uma teórica apresentada neste texto e uma sobre as práticas, baseada nas histórias de vida dos professores, que será tratada posteriormente, durante o desenvolvimento de nosso trabalho.

\section{De 1549 a 1920: iniciativas antes da produção universitária no Brasil}

Em linhas gerais, traçamos a história das contribuições ao pensamento geográfico e da educação no Brasil, desde 1549, ano em que os jesuítas aqui chegaram com o compromisso de educar os colonos e os índios, sob a direção do padre Manuel da Nóbrega.

De acordo com Saviani (2008, p.86), o referido padre elaborou um plano que traçava as linhas gerais da educação na colônia: "Levando em conta as peculiaridades da colônia, o plano de instrução 
formulado pelo padre Manuel da Nóbrega, começava na escola de ler e escrever com a aprendizagem do português e da doutrina católica e [aulas de música]".

Após esses estudos elementares que correspondiam ao nível primário, o plano previa uma bifurcação em nível secundário: a maioria dos alunos era encaminhada para o aprendizado de ofícios mecânicos ou agrícolas; e uma parte menor era selecionada para estudos latinos [para poderem completar sua formação na Europa] (ibidem).

Após Nóbrega, Anchieta assumiu o comando e promoveu algumas mudanças no plano de instrução, tendo sido influenciado pela chamada Contrarreforma, aprendeu a língua tupi e usou elementos da cultura indígena para aprofundar a aceitação da filosofia católica. Já em 1584, foi editado o Ratio Studirum, um documento com 467 regras sobre a gestão e a prática da educação nos colégios jesuítas em todo o mundo. Com isso, ainda segundo Saviani (2008, p.90):

Em suma a teoria da educação (pedagogia) vigente no $1^{\circ}$ século da colonização brasileira traduziu, para efeitos da organização e orientação prática educativa levada a efeito pelos jesuítas, a concepção tradicional religiosa, isto é, a filosofia da educação católica ajustando-se as condições particulares da colônia.

Nesse período, as contribuições de ordem geográfica vinham dos trabalhos dos cronistas coloniais que produziam vários ensaios literários sobre temas diversos, e alguns tratavam de temas ligados à geografia, mas sem pretensões científicas. Outros eram cientistas que faziam expedições pelo país e traziam descrições sobre diversos aspectos dos lugares visitados. Até então, esses conhecimentos chegavam aos colégios apenas de forma esparsa como parte dos estudos de literatura.

O sistema elaborado e dirigido pelos jesuítas e solidificado pelo Ratio Studirum só foi modificado pelas Reformas Pombalinas que, segundo Seco \& Amaral (2009, p.12):

Através do Alvará Régio de 28 de junho de 1759, o Marquês de Pombal, suprimia as escolas jesuíticas de Portugal e de todas as 
colônias ao expulsar os jesuítas da colônia e, ao mesmo tempo, criava as aulas régias ou avulsas de Latim, Grego, Filosofia e Retórica, que deveriam suprir as disciplinas antes oferecidas nos extintos colégios jesuítas.

Essas reformas prevaleceram no país até 1808, quando começou a ser divulgado o método do "ensino mútuo", que se tornou oficial em 1827, e consistia em regras rígidas e na utilização dos alunos mais adiantados como monitores para os demais, todos supervisionados pelo professor (Saviani, 2008).

Mesmo, porém, com grandes mudanças no que tange a organização e os métodos de ensino, o conhecimento geográfico ainda era restrito a instituições públicas e a exploradores, chegando às escolas apenas imagens vagas do que seria o território brasileiro. Em decorrência da vinda de muitos "cientistas" europeus ao Brasil, começou a haver alguma mudança na produção de conhecimento geográfico no país. Mesmo que esparsos e sem objetivo metodológico científico, a maior parte desses trabalhos era realizada para satisfazer os interesses do Estado.

Em 1817, é publicada pela Imprensa Régia uma das primeiras obras de grande influência para os professores de geografia, a Corografia Brasílica, de autoria do padre Manuel Aires de Casal. A referida obra estava filiada à geografia clássica, com conteúdo descritivo e superficial tratando de países e povos. Era constituída por compilação de dados informativos desprovidos de caráter crítico (Rocha, 1996, p.140).

Em 1822 é proclamado o Império do Brasil e, nesse período, encontramos poucas referências sobre a geografia. Uma delas foi o trabalho de Pedroso (1962) que deu ênfase a alguns poucos autores que contribuíram para o conhecimento da realidade brasileira, especialmente os aspectos naturais. No que tange o ensino, era focado na descrição e memorização das formações relatadas por viajantes estrangeiros, como Saint Hilaire, citando também o Visconde de Taunay e Couto de Magalhães.

O percurso da geografia escolar brasileira é objeto de estudo de Rocha (1996). Com um trabalho original no país, o pesquisador traça 
a trajetória da geografia escolar no Brasil. Busca desvelar os motivos explicativos da seleção dos conteúdos no currículo prescritivo, ou explícito, a partir da análise bibliográfica e de textos de caráter técnico e oficial.

Em 1832, a geografia passa a compor o currículo no sistema escolar brasileiro. Foi introduzida, como disciplina secundária, mas autônoma, pela reforma do Plano de estudos da Companhia de Jesus, denominado de Ratio ataque Institutio Studiorum Societatis Jesu. Oficializado em 1599, funcionava como uma verdadeira lei a ser cumprida em todos os estabelecimentos de ensino criados pelos religiosos (Rocha, 1996, p.125 e passim).

Devemos apontar que, nesse mesmo início do século, na Alemanha, a geografia começou a ser organizada cientificamente, em especial por Humboldt e Ritter, que definiram princípios de pesquisa e análise baseados no positivismo das ciências naturais, estabelecendo o primeiro grande paradigma da ciência geográfica.

Somente em 1837, com a criação do Imperial Colégio de Pedro II, a geografia adquiria no currículo escolar oficial brasileiro o estatuto de disciplina autônoma.

A criação do Colégio Pedro II, datada de 1837, tinha como intenção dotar a corte (Rio de Janeiro) de um sistema de Ensino Médio mais organizado diante da desordem reinante após a reforma da instrução pública, iniciada com a fase pombalina da escolarização colonial.

Quando de sua criação, o Colégio Pedro II foi alvo da atenção especial do poder central. Nasceu para ser uma instituição paradigmática no país, veículo de difusão do saber oficialmente aceito e modelo a ser seguido pelas demais escolas públicas e particulares existentes, e por aquelas que viessem a surgir (Rocha, 1996, p.149).

Ainda segundo Rocha, desde seu primeiro regulamento, datado de 1838, que introduziu os estudos simultâneos e seriados, curso regular com duração de seis a oito anos, conforme o modelo francês, o Colégio Pedro II passou por inúmeras reformas. Até a última reforma para o ensino ministrado no colégio, por meio do Decreto de 1881, o ensino de geografia permaneceu praticamente inalterado em 
suas características "de nítida orientação clássica, ou seja, a Geografia descritiva, mnemônica, enciclopédica..." (ibidem, p.178).

No campo educacional, na segunda metade do século XIX emerge no Brasil o chamado método intuitivo idealizado por Pestalozzi, que inovou as ferramentas de ensino que dariam subsídio à orientação do professor para os alunos. Além disso, esse método baseia-se no oferecimento de experiências para os alunos para que, orientados pelo professor, possam ser intuídos sobre a origem e funcionamento das coisas.

O método intuitivo, adotado na reforma de Caetano de Campos na Educação Paulista na década de 1890, foi referência até a década de 1920, quando surge o movimento Escola Nova.

Nesse final do século XIX e início do XX, surgiram ensaios que, de certa forma, anteciparam a formação da geografia sistematizada, entre eles: Os sertões, de Euclides da Cunha, e Caminhos antigos e povoamento do Brasil, de Capistrano de Abreu (Andrade, 1987).

Nesse mesmo período, segundo Amorim Filho (1982), emergiu uma reação à geografia alemã, com as contribuições de Hettner, que dividiu a geografia em geral e regional. La Blache, grande representante da Escola Francesa, foi quem definiu, em linhas gerais, os princípios da geografia regional em: ênfase na relação homem meio; a região como meio privilegiado da análise geográfica; importância da análise do visível; o método indutivo de análise.

De acordo com o autor citado, as contribuições posteriores não chegaram a romper totalmente com o paradigma, mas juntaram-se a ele, dando ênfase a algumas questões e marginalizando outras. No Brasil, um divisor de águas deve ser creditado a Delgado de Carvalho que, com suas obras mais gerais, como Le Brésil Meridional e Geografia Física do Brasil, pode ser considerado um marco do desenvolvimento geográfico brasileiro. Ressaltando também os livros "didáticos" que esse autor publicou (Andrade, 1987).

Outros autores também publicaram obras-chave para a geografia brasileira na década de 1920, como Agamenon Magalhães, analisando a sociedade nordestina, e Raimundo Lopes, analisando regionalmente o Maranhão. 


\section{De 1920 a 1960: a formação do espaço universitário e a Escola Nova}

As décadas de 1920-1930 marcam revoluções tanto na recémchegada ciência geográfica, com a fundação da Faculdade de Filosofia, Letras e Ciências Humanas (FFLCH) da Universidade de São Paulo (USP) em 1934, quanto na pedagogia com o movimento escolanovista, marcado pelo Manifesto dos Pioneiros da Educação Nova em 1932. Revolução que atingiu também o ensino de geografia nas escolas, com as obras de Delgado de Carvalho e o currículo elaborado pelo Colégio Pedro II no Rio de Janeiro. Com isso consideramos oportuno e didático abordar o período de 1920-1960 de forma separada do anterior e também do posterior, quando as modificações desse período foram suplantadas.

Já no fim do Império e durante a Primeira República, a instrução pública sofre intensas modificações, num processo de tomada pelo Estado da responsabilidade que estava por conta da Igreja católica. Em especial, sobre o período da Primeira República (1889-1930), destacamos as mudanças apresentadas no Quadro 2.

Tais mudanças deram margem a um movimento que ganhou força a partir do Manifesto dos Pioneiros da Educação Nova e foi reforçado por autores (como Lourenço Filho e Anísio Teixeira) e instituições, como a recém-criada Faculdade de Educação da Universidade de São Paulo e a Associação Brasileira de Estatística (ABE).

O chamado Movimento Escola Nova segue uma tendência dos seguidores de John Dewey, que foca no aluno o processo de aprendizagem e afirma que a escola é um reflexo da sociedade em que ela se insere. Segundo Saviani (2008, p.99), esse movimento trouxe para a escola as seguintes diretrizes: "abandono do autoritarismo, em favor da liberdade; a afirmação da autoridade interna sobre a externa; a afirmação de uma nova finalidade da escola, traduzida no objetivo de preparar o indivíduo para dirigir a si mesmo numa sociedade mutável".

Mesmo assim, conforme nos informa Pedroso (1966), prevalecia nas escolas, e em particular nas aulas de geografia, o excesso de infor- 
Quadro 2-Geografia escolar e as principais reformas no ensino durante a Primeira Republica brasileira

\begin{tabular}{|c|c|c|c|}
\hline Mudança & Data & $\begin{array}{c}\text { Principais } \\
\text { características }\end{array}$ & Posição da geografia \\
\hline $\begin{array}{l}\text { Reforma } \\
\text { Benjamin } \\
\text { Constant }\end{array}$ & 1891 & $\begin{array}{l}\text { Instituiu o ensino } \\
\text { livre e os exames de } \\
\text { madureza para os } \\
\text { cursos superiores }\end{array}$ & $\begin{array}{l}\text { A geografia era unida à história, } \\
\text { sendo estudada em duas partes, } \\
\text { geografia geral e geografia do } \\
\text { Brasil, ambas acompanhadas por } \\
\text { sua homônima na história }\end{array}$ \\
\hline Lei Epitácio & 1901 & $\begin{array}{l}\text { Aboliu os cursos } \\
\text { livres e os exames } \\
\text { de madureza } \\
\text { e restaurou o } \\
\text { bacharelado. } \\
\text { Estabeleceu como } \\
\text { padrão o Colégio } \\
\text { Nacional }^{1}\end{array}$ & $\begin{array}{l}\text { Nos ginásios paulistas exigiam-se } \\
\text { aulas de geografia no } 1^{\circ}, 2^{\circ} \text { e } 3^{\circ} \\
\text { anos. Surgem novos livros para } \\
\text { o ensino, como: A corografia de } \\
\text { Pinheiro Bittencourt e o Atlas do } \\
\text { Barão H. de Melo }\end{array}$ \\
\hline $\begin{array}{l}\text { Lei } \\
\text { Rivadávia }\end{array}$ & 1911 & $\begin{array}{l}\text { Reforma } \\
\text { retrocessiva, } \\
\text { que reinstituiu o } \\
\text { Madureza }\end{array}$ & $\begin{array}{l}\text { Durou apenas três anos e não foi } \\
\text { implementada em SP, MG e BA }\end{array}$ \\
\hline $\begin{array}{l}\text { Lei Carlos } \\
\text { Maximiliano }\end{array}$ & 1915 & $\begin{array}{l}\text { Instituiu os exames } \\
\text { parcelados, correlato } \\
\text { ao curso-vestibular } \\
\text { contemporâneo }\end{array}$ & $\begin{array}{l}\text { Entre os exames havia um de } \\
\text { geografia que era considerado } \\
\text { fundamental e de caráter } \\
\text { eliminatório. Composto por uma } \\
\text { prova escrita e uma oral, com } \\
\text { conteúdo bastante vago, baseado } \\
\text { nos programas do Colégio } \\
\text { Pedro II, seu estudo constava } \\
\text { de três partes: Geografia geral, } \\
\text { Corografia do Brasil e Noções de } \\
\text { cosmografia }\end{array}$ \\
\hline $\begin{array}{l}\text { Reforma } \\
\text { Rocha Vaz }\end{array}$ & 1926 & $\begin{array}{l}\text { Substituiu os } \\
\text { exames parcelados } \\
\text { por um curso } \\
\text { seriado de cinco } \\
\text { anos }\end{array}$ & $\begin{array}{l}\text { Como no regime parcelado, a } \\
\text { geografia aparece em três anos } \\
\left(1^{\mathrm{a}}, 2^{\mathrm{a}} \text { e } 5^{\mathrm{a}}\right) \text { e surgem novos livros, } \\
\text { alguns já afiliados à Escola } \\
\text { Francesa, como os de Delgado de } \\
\text { Carvalho }\end{array}$ \\
\hline
\end{tabular}

Fonte: Organização própria, baseado em Pedroso (1966).

1 Atual Colégio Pedro II. 
mações e memorização, seja sobre os aspectos físicos ou humanos do Brasil e do mundo, como exemplo citamos os exames de Madureza (que existiram até 1926), para os quais os aluno deveriam decorar informações enciclopédicas, como os nomes de todas as serras de vários Estados do país.

No contexto político, com a Revolução de 1930, houve uma ruptura com as antigas oligarquias, o que gerou conflitos, como a Revolução de 1932. Dessa forma, a elite paulista procurou investir em meios de formar melhor seus líderes e tal movimento veio a culminar na fundação da Universidade de São Paulo, em 1934. Assim, surgiram condições para a proliferação de autores, como Caio Prado Junior, que passaram a analisar a sociedade brasileira (Andrade, 1987).

No contexto nacional, tal movimento foi acompanhado pelo governo federal com a fundação da Universidade do Brasil (RJ) e do Instituto Brasileiro de Geografia e Estatística (IBGE), que também se tornaram grandes centros de produção de conhecimento.

Em 1932, começa a implementação da Reforma Francisco de Campos que, baseada no modelo alemão, dividiu o ensino secundário em dois ciclos: o ginasial, de cinco anos, e o complementar, de dois anos. Com um novo currículo, a geografia aparece em todas as séries do ginásio. Contudo, foi colocada no final do extenso programa, ficando de lado muitas vezes. Quanto aos livros didáticos do período, surgem os de Aroldo de Azevedo e Raja Gabajiba, entre outros.

No âmbito estadual, de acordo com os pressupostos filosóficos expressos no Manifesto [dos Pioneiros da Educação Nova], o Decreto n.5.884/1933 reorganizou todo o sistema de ensino paulista, instaurando, segundo Martins (2003, p.527):

A organização administrativo-pedagógica das escolas rurais isoladas e das escolas de formação do professor primário e secundário. Um de seus artigos afirmava que o professor deveria ter "autonomia didática dentro das normas técnicas gerais indicadas pela pedagogia contemporânea". 
Especificamente sobre o impacto dessa reforma sobre o ensino de geografia, encontramos um artigo de Federici (1957) que ressalta a criação das salas-ambiente operada pela reforma. Segundo o autor, tal possibilidade enriqueceu o ensino da disciplina, visto que os alunos poderiam ter contato direto com os mapas, as rochas e os quadros referentes ao assunto, o que exemplifica as preocupações didáticas da época.

Como apontado anteriormente, um marco importante foi a fundação da Faculdade de Filosofia, Letras e Ciências Humanas da USP em 1934. No âmbito da geografia acadêmica, criou-se o primeiro curso superior de geografia. Para tal iniciativa foi necessária a vinda de professores estrangeiros, notadamente franceses, como Deffontaines e Pierre Monbeig, que trouxeram para o país uma ciência geográfica bastante influenciada pela Escola Francesa, baseada em Vidal de La Blache. Para a geografia escolar, isso foi significativo, pois deu início à profissionalização da docência na medida em que passou a formar profissionais qualificados para o exercício do magistério. Cabe observar que os professores de geografia, até então, eram profissionais graduados em áreas diversas, como direito, engenharia, entre outras, e os cursos eram compostos, por vezes, por professores leigos.

Tal tendência caracterizou-se, segundo Pontuschka (2002), por dar grande destaque para as questões regionais, seguindo as linhas do método de La Blache, que propunha: observação de campo, indução a partir da paisagem, particularização da área enfocada, comparação entre áreas e classificação, até uma tipologia.

De acordo com Pedroso (1966), a Reforma Capanema (1941) manteve os dois ciclos, porém o curso ginasial ficou com quatro anos e o colegial, com três anos. Este último, subdividido em duas modalidades: o científico, mais técnico, e o clássico, focado nas humanidades.

A geografia tornou-se obrigatória para todas as séries dos dois ciclos e ganhou novos instrumentos didáticos, entre livros e atlas. Segundo o autor, a imposição de uma fiscalização federal às escolas, a despeito da rigidez curricular, agregou mais qualidade ao ensino (ibidem). 
Na década de 1940, surgem os primeiros cursos de formação de professores de geografia. Ocorre a proliferação de concursos públicos para arregimentar professores para as escolas públicas (no Estado de São Paulo eles iniciam em 1943) e nascem a Associação de Geógrafos Brasileiros (AGB), o Conselho Nacional de Geografia (CNG) e o Instituto Brasileiro de Geografia e Estatística (IBGE).

Como apontado anteriormente, tais fatos, entre outros, foram de fundamental importância para a formação do professor especialista e para a construção da trajetória da disciplina Geografia no currículo escolar nacional.

Cabe ressaltar que a AGB e o CNG contribuíram sobremaneira para a consolidação e fortalecimento das pesquisas geográficas do país e, consequentemente, para a produção de material destinado ao ensino. Nesse aspecto, Santos (1984, p.15) ressalta o importante papel das entidades acima na difusão "da mentalidade geográfica renovadora que se desenvolvia no exterior".

Goodson (1990) faz breve análise da influência dos fatores externos interferindo no dinâmico processo de consolidação da geografia. Trata especialmente das questões relacionadas à organização do conteúdo da disciplina na escola. Ao analisar o processo de constituição dessa disciplina, o autor aponta para a importância da organização dos professores em associações e analisa a dinâmica da produção acadêmica dando sustentação para a consolidação da matéria escolar.

\section{De 1960 a 2009: da LDB e a revolução quantitativa ao pluralismo epistemológico}

Em razão do caráter sintético do texto e a maior riqueza de dados referentes a esse período, preferimos tratá-lo separadamente em outro trabalho ainda em construção. Admitimos o corte abrupto na narrativa, mas o consideramos necessário para que pudéssemos dar a atenção devida aos períodos aqui apresentados e a este último. 


\section{Considerações finais: uma história da geografia escolar em processo}

Nossos estudos a respeito da história da geografia como disciplina escolar no Brasil têm apontado uma trajetória muito semelhante aos apresentados por Goodson (1990) na Inglaterra. Na perspectiva de que a escola trabalha com os conhecimentos considerados "úteis" em determinado contexto histórico, o autor apresenta três fases do processo histórico de constituição da geografia como "matéria" escolar.

Em um primeiro momento, denominado de "período dos cabos e baias", os conteúdos escolares da disciplina se configuram em uma monótona coleção de fatos e cifras ensinados por não especialistas.

No segundo período, a disciplina deixa de constar como matéria subsidiária de outra e passa a ter o estatuto de disciplina autônoma, com existência curricular garantida pela legislação. Cabe lembrar, como aponta Rocha (1996), inicialmente, a geografia era ensinada junto à matemática. Houve, também, épocas em que a geografia escolar era concebida como subsidiária da história.

\section{Referências}

ANDRADE, M. C. Uma geografia para o século XXI. Campinas: Papirus. 1994

Pierre Monbeig e o pensamento geográfico no Brasil. Boletim Paulista de Geografia, São Paulo, n.72. s. d.

BUENO, B. O. O método autobiográfico e os estudos com histórias de vida de professores: a questão da subjetividade. Educ. Pesqui., São Paulo, v.28, n.1, jan./jun. 2002.

CAVALCANTI, L. S. Geografia, escola e construção do conhecimento. 3.ed. Goiânia: Papirus, 1998.

Cotidiano, mediação pedagógica e formação de conceitos: uma contribuição de Vigotsky ao ensino de Geografia. Cadernos Cedes, Campinas, v.25, n.66, p.185-207, maio/ago. 2005.

CAPEL, H. Filosofía y ciencia en la geografia contemporánea. Barcelona: Bacanova Temas Universitarios, 1981. 
CHERVEL, A. História das disciplinas escolares: reflexões sobre um campo de pesquisa. Revista Teoria e Educação, Porto Alegre, n.2, 1990.

JACINTO, A. A. O ensino de geografia: uma análise dos livros didáticos de $1^{\circ}$ grau na primeira metade da década de 80 . Trabalho de Conclusão de Curso. Unesp - Rio Claro, 2000.

ECO, U. Como se faz uma tese em ciências humanas. São Paulo: Presença, 1998.

FAZENDA, I. (Org.) Metodologia da pesquisa educacional. 10.ed. São Paulo: Cortez. 2006. (Biblioteca da Educação, série I, Escola; v.II).

FEDERICI, H. O problema da sala-ambiente e do material didático no ensino da Geografia. Atualidades Pedagógicas, Campinas, n.42, dez. 1957.

GOODSON, I. Tornando-se uma matéria acadêmica: padrões de explicação e de evolução. Revista Teoria E Educação, Porto Alegre, n.2, 1990. Studying the teacher's life and work. Teaching and Teacher Education, Oxford, v.10, n.1, p.29-37, 1994.

KAERCHER, N. A. Desafios e utopias no ensino de Geografia. 3.ed. Santa Cruz do Sul: Edunisc. 2003.

LACOSTE, Y. A Geografia serve, antes de mais nada, para fazer a guerra. Lisboa: Iniciativas. 1988.

MARTINS, A. M. A Política Educacional paulista: controvérsias em torno dos conceitos de descentralização e autonomia-1983 a 1999. Educ. Soc., Campinas, v.24, n.83, p.527-49, ago. 2003. Disponível em: <http:// www.cedes.unicamp.br>.

MARTINS, H. H. T. de S. Em foco: pesquisa sociológica e metodologia qualitativa. Educ. Pesqui., São Paulo, v.30, n.2, May/Aug. 2004.

MOREIRA, I. A. G. A geografia como ciência humana e de síntese e as implicações no ensino secundário. Boletim Geográfico, São Paulo, v.29, n.218, p.76-80, 1970.

OLIVEIRA, A. U. (Org.) Para onde vai o ensino de geografia? 8.ed. São Paulo: Contexto, 2003. (Série: Repensando o ensino).

PADILHA, F. A. O estudo dirigido em Geografia. Boletim Geográfico, São Paulo, v.27, n.202, p.56-9, 1968.

Recomendações didáticas para o professor de Geografia. Boletim Geográfico, São Paulo, v.27, n.203, 1968.

PEDROSO, T. A Geografia no Curso Secundário. Boletim Geográfico, São Paulo, ano XXV, v.25, n.194, p.475-95, sete.-out. 1966.

PEREIRA, R. M. F. A. Da Geografia que se ensina à gênese da Geografia Moderna. Florianópolis: Editora da UFSC, 1993.

PINTO, M. M. V. O Ensino da Geografia em face da Lei de Diretrizes e Bases. Boletim Geográfico, São Paulo, ano XXII, v.22, n.180, p.396-8, maio-jun. 1964. 
PONTUSCHKA, N. N. A geografia: pesquisa e ensino. In: CARLOS, A. F. A. (Org.) Novos caminhos da Geografia. São Paulo: Contexto. 2002, p.111-42.

ROCHA, G. O. R. Trajetória da disciplina Geografia no currículo escolar brasileiro (1837-1942). Dissertação (Mestrado) - Pontifícia Universidade Católica, São Paulo, 1996.

SANTOS, W. dos. A obra de Aroldo Azevedo - Uma avaliação. Dissertação (Mestrado) - Instituto de Geociências e Ciências Exatas, Universidade Estadual Paulista "Júlio de Mesquita Filho", Rio Claro, 1984.

SAVIANI, D. A pedagogia no Brasil: história e teoria. Campinas: Autores Associados, 2008. (Col. Memória da Educação).

VESSENTINI, J. W. (Org.) Ensino de Geografia: textos críticos. São Paulo: Papirus, 2001.

ZAMORANO, M. O Ensino de Geografia na Escola Secundária. Boletim Geográfico, São Paulo, ano XXVIII, v.28, n.212, p.116-51, 1969. 
Parte II 



\title{
5 \\ DOS MODELOS À EXPLICAÇÃO: a Nova Geografia em David Harvey
}

\author{
Danilo Piccoli Neto*
}

\section{Introdução}

A obra Explanation in Geography de David Harvey (1969) figura entre os marcos da Nova Geografia e de todo o pensamento geográfico, pela sua densidade de conteúdos e formas explicativas na busca de uma sistematização teórica e metodológica do conhecimento e da explicação científica em geografia. Objetiva-se com o presente texto elencar algumas das principais contribuições que esse trabalho propiciou para o movimento de renovação da geografia e para o corpus teórico/metodológico da disciplina.

Buscam-se também correlações com o momento histórico da geografia na época de redação da obra, especialmente no contexto anglo-americano, colocando os elementos históricos mais destacados que remontam à constituição e gênese da chamada Nova Geografia, e posteriormente, a postura ideológica e concepção de ciência possíveis de serem traçadas em David Harvey nesse período. Alguns pontos iniciais da trajetória de David Harvey são retomados, como

* Doutorando do Programa de Pós-Graduação em Geografia, Unesp - Rio Claro (SP). Bolsista Fapesp. 
os tempos de universidade e os escritos que antecedem a publicação de Explanation, dentre eles, o capítulo no livro de Chorley \& Haggett (1967), Models in Geography, que projeta o jovem professor.

O momento é singular ante os quarenta anos completados pela obra Explanation in Geography em 2009, leitura altamente indicada em geografia teorética, História do Pensamento Geográfico, e para a retomada de novos debates acerca dos futuros desdobramentos epistemológicos em geografia.

\section{As décadas de 1950 e 1960 - Emergência da Nova Geografia}

No período que vai de 1930 a 1950, a geografia anglo-americana esteve dominada pela visão regional ou de diferenciação de áreas e buscava construir uma síntese das características de uma região (Paterson, 1984, p.20). Para cumprir essa tarefa, realizava um inventariado peculiar das características particulares de cada lugar (Barnes, [no prelo]), com extensos campos e detalhamento descritivo de elementos da paisagem, mostrando quadros compartimentados, com o clima, o relevo, a hidrografia, a economia dominante, os hábitos culturais etc.

O cenário começa a se alterar com as mudanças paradigmáticas advindas do seio da própria ciência em geral, com novas teorias especialmente no campo da física teórica, com Einstein e Bohr, que vão refletir na filosofia da ciência e no modo como o conhecimento é adquirido; novos esforços são oferecidos por escolas como a do Círculo de Viena, e o pós-guerra coloca a necessidade de uma nova forma de aplicação do conhecimento científico. Evidentemente, essas mudanças se espalham pelos demais ramos naturais e sociais da ciência e atingem o campo do saber geográfico, uma verdadeira revolução no modo de se fazer estudos em geografia é eminente.

Na década de 1950, começa a emergir a visão de "ciência espacial”, primeiramente na Universidade de Washington, em Seattle, 
onde trabalhos como The Basic-Service Ratio and the Areal Support of Cities e The Role of Transportation and the Bases for Interaction, de Ullman (1953 e 1956); Studies of Highway Development and Geographic Change, de Garrison et al. (1959); e The functional bases of the central place hierarchy, de Berry \& Garrison (1958), continham a ideia de que o objeto da geografia era a dimensão espacial da superfície terrestre, e que, para estudá-lo, era necessário o uso de matemática, técnicas estatísticas e formulações teóricas. Ao mesmo tempo, surgiam no âmbito da economia críticas com respeito à falta do caráter espacial nos sistemas econômicos, o que fez que em 1954 fosse fundada a Regional Science Association, por Isard, e que teve rápida aproximação com os trabalhos da Nova Geografia que começava a se delinear (Paterson, 1984, p.21).

A Nova Geografia ganha sua expressão estatística e matemática e sob Burton (1963) e Curry (1967) esse movimento ganha o rótulo de "revolução quantitativa", o que de certa forma evidencia mais o lado operacional estatístico dessa corrente, sem frisar a parte teórica que trazia consigo uma nova maneira de se proceder para a aquisição do conhecimento científico em geografia, no Brasil, denominado "Geografia Teorética".

Não faltam contribuições e debates nesse período para que a geografia se enquadre no modelo científico. O trabalho de Bunge (1962), Theoretical Geography, traz a questão do uso do método científico; no trabalho de Golledge \& Amadeo (1968), On laws in geography, tem-se a referência à formulação de leis; a preocupação com a construção de modelos é tema da obra Models in Geography de Chorley \& Hagget (1967); enquanto as questões referentes à formulação teórica encontram-se em Theoretical Geography de Bunge (1962), e The quantitative revolution and theoretical geography de Burton (1963).

Na Inglaterra, essa "ciência espacial geográfica" foi dominada pela escola de análise locacional, especialmente nos centros de Bristol e Cambridge, e, de acordo com James (apud Paterson, 1984, p.21), Chorley, Hagget e Harvey foram os líderes mais destacados nesse movimento. 


\section{Inovações e contribuições - um paralelo com o momento histórico}

É na Universidade de Cambridge que Harvey forma-se como geógrafo no ano de 1957 e finda seu doutorado em 1961. Em Cambridge, ocupavam assento acadêmico até 1966 duas grandes referências da Nova Geografia que em muito contribuíram para oferecer bases conceituais e práticas ao movimento renovador em curso - e pelo próprio chamamento carinhoso que Harvey (1969, p.ix) faz no prefácio de Explanation a essas duas personalidades, podemos ter noção de seu impacto no meio acadêmico e da disposição em divulgar os novos conhecimentos - eram os "gêmeos terríveis" da geografia britânica, Richard Chorley e Peter Haggett.

Nesse período, Harvey realiza estágio de assistente de ensino durante sua pós-graduação e auxilia os trabalhos dos dois professores, ligados aos métodos quantitativos e à modelagem. Desse período resultam artigos acadêmicos com referências e usos de técnicas quantitativas aplicadas em geografia, como cadeias de Markov e, especialmente, um capítulo no livro Models in Geography, de Chorley \& Haggett (1967), intitulado "Models of the Evolution of Spatial Patterns in Human Grography", que pela grande aceitação do livro projeta o nome de Harvey; a análise desse capítulo será retomada adiante. Em seu doutorado, intitulado Aspects of agricultural and rural change in Kent, 1815-1900, Harvey também aplica técnicas estatísticas e modelos como o de Lösch. Esses podem ser considerados os pré-manuscritos que irão ser mais bem desenvolvidos por Harvey em Explanation. Barnes (2006, p.40) também faz menção à influência do professor Tony Wrigley, demógrafo histórico, que introduziu Harvey ao pensamento mais geral do século XIX, o positivismo de Auguste Comte e o pensamento de Marx; o que vem a sustentar a base filosófica de Harvey, enquanto Chorley e Haggett auxiliam na formação da base do método científico.

A continuidade desse processo se dá na Universidade de Bristol, onde Harvey encontra subsídios e elementos para concretizar seu primeiro livro, e é nesse local que se dá a maior parte da redação da obra, 
onde o jovem Harvey já se encontra como professor e tem novamente a figura de Haggett, recém-contratado pela universidade em 1966, como professor de geografia urbana e regional, e agora seu colega de trabalho. Explanation in Geography é resultado de quase uma década de ensino de graduação na Universidade de Bristol sobre a "nova base" científica para trabalhar a geografia, e não menos do que isso, é fruto de debates com colegas na Suécia e nos Estados Unidos, já que Harvey realizou um pós-doutoramento na Universidade de Uppsala entre 1960 e 1961, e muito provavelmente tomou conhecimento da vertente da Nova Geografia que se desenvolvia na Suécia, a visão temporo-espacial dos trabalhos iniciais de Hägerstrand.

Barnes (2006, p.34) sintetiza esse momento fundamental na carreira de Harvey e na elaboração de Explanation:

The broader point is that the Department of Geography at Cambridge during the period Harvey was a student, and later a young lecturer at Bristol, was a "truth spot". That is, it was one of an initially small number of sites in Europe and North America, and which by the mid-1960s included Bristol, where geographical practices were remade in the likeness of natural science in a movement dubbed "the quantitative revolution" (Barnes 2001, 2004). That revolution was to move the discipline from the dark ages of its ideographic past to the dazzling promise of a nomothetic future. As a young, bright, ambitious student interested in ideas, Harvey inevitably was caught up in the change even though it went against the grain of his "strong 'Arts' background" (Harvey 1969a: v). Indeed, it may have been that Arts background that made him move away from his earlier sometimes fumbling attempts at quantitative analysis to the later philosophical and discursive treatment found in Explanation. ${ }^{1}$

1 Tradução do autor: "O ponto principal é que o Departamento de Geografia na Universidade de Cambridge durante o período em que Harvey era um estudante e, posteriormente, a Universidade de Bristol, onde Harvey era um jovem professor, eram um 'ponto de verdade', ou seja, eram alguns dos locais, de um número inicialmente pequeno na Europa e América do Norte, onde em meados da década de 1960 as práticas geográficas foram refeitas, à semelhança 
Trata-se de um verdadeiro guia de estudos e referencial para se proceder a uma pesquisa científica em geografia. Observando o livro desse modo, vê-se que, ao se propor um guia, é porque claramente um novo modo de se fazer as coisas é possível, e sendo novo, necessita de maior clarificação dos procedimentos. Harvey (1969, p.v) coloca que, acima de tudo, o livro foi escrito para a sua própria educação, ou seja, foi a forma que o autor encontrou para concatenar o processo de aprendizagem que vinha desenvolvendo, na perspectiva de tornar claro a si mesmo todo o acúmulo de conhecimento e informação adquirido durante sua formação acadêmica e na sua prática de ensino, que, como vimos, sofreu grande influência da Nova Geografia que vinha surgindo.

Esse novo modo também não pode ser algo esparso, sem nexo, deve estar ligado a um corpus teórico que viabilize a tomada operacional de análise, já que Explanation visa dar uma contribuição à geografia, quanto à sua forma de proceder para tornar a pesquisa realmente científica. E nesse ponto a obra traz contribuições relevantes quanto ao método hipotético-dedutivo em geografia, necessário para os pressupostos e anseios de tornar a geografia uma disciplina científica.

Os geógrafos tiveram de avançar nesse sentido. No campo da geografia física a derivação de teorias a partir de postulados e axiomas possibilitou a capacidade de dedução, como a paisagem produtora de processos e as formas provavelmente resultantes de leis físicas. $\mathrm{Na}$ área de geografia humana, hipóteses relacionadas ao comportamento humano possibilitaram deduções de padrões espaciais.

dos métodos das ciências naturais, em um movimento chamado de 'revolução quantitativa' (Barnes 2001, 2004). Essa revolução mudaria a disciplina da Idade das Trevas e seu passado ideográfico para a deslumbrante promessa de um futuro nomotético. Como jovem e brilhante aluno, ambicioso interessado nas idéias, Harvey foi inevitavelmente apanhado por esta mudança, mesmo que fosse contra a semente de seu 'forte conhecimento das 'artes" (Harvey, 1969a: v). Na verdade, pode ter sido esse conhecimento das artes que o fez afastar-se da sua anterior, às vezes desastrada, tentativa de análises quantitativas, para o mais filosófico e discursivo tratamento encontrado em Explanation". 
Outra contribuição foi o uso de técnicas quantitativas. Para Harvey, também, a quantificação foi necessária, mas longe de ser suficiente: essa medida foi uma ferramenta necessária, mas muito mais importante foi para os geógrafos humanos e físicos para avaliar e implantar a filosofia que subderrotou o "poder fantástico" do modelo científico (Johnston, 2008). A leitura que Harvey (1969, p.viii) fez desse momento resulta em Explanation, "this book is therefore about the ways in which geographical undestanding and knowledge can be acquired and the Standards of rational argument and inference that are necessary to ensure that this process is reasonable". ${ }^{2}$

De acordo com Johnston (2008), o modelo de Harvey em relação à Nova Geografia foi a representação de uma teoria - isto é, um resultado de uma série de leis, como declarações. Tais representações se tornaram a fonte de hipóteses, conduzindo a testes de validade empírica da teoria. O exemplo de uma teoria em geografia humana que ilustra esses conceitos fundamentais é a teoria dos lugares centrais: base para um grande volume de trabalhos geográficos na década de 1950 de 1960.

Harvey mostra que ela era derivada de um conjunto de postulados fundamentais econômicos (assumindo leis) sobre o comportamento do consumidor e fornecedor com minimização dos custos de transporte para os consumidores de acordo com a natureza dos produtos/ serviços que estão sendo fornecidos. Esses são ligados em uma única teoria, a partir da qual é possível deduzir o arranjo espacial dos centros de serviço. Modelos poderiam ser derivados mostrando a morfologia esperada do arranjo espacial em diferentes contextos, que tinham características comuns, tais como o arranjo hexagonal de centros em hierarquias de nidificação. Hipóteses específicas poderiam então ser testadas em determinadas situações empíricas (Johnston, 2008; Barnes, 2006). Para Harvey (1969, p.169), o mais importante

2 Tradução do autor: "este livro é, portanto, sobre as formas em que a compreensão geográfica e conhecimento podem ser adquiridos e as normas da argumentação racional, considerando que são necessárias para garantir que o processo seja razoável". 
desses conceitos era a teoria: "without theory of some kind the explanation and cognitive description of geographic events is inconceivable". ${ }^{3}$

\section{Trilhando o caminho da explicação: modelos em geografia humana}

É sob o "contínuo ato de escolher e na ressalva perpétua do julgamento", palavras de Lawrence Durrel, que Harvey abre o capítulo "Modelos da evolução dos padrões espaciais na geografia humana", contido na obra Models in Geography. ${ }^{4}$ Palavras que já dão indícios de uma apreensão parcial da realidade, que só é possível por meio de recortes específicos, recortes que necessitam de uma escolha e que não podem ser cristalizados estarão sempre a julgo e possíveis de serem postos em xeque.

Partindo de uma concepção de Hartshorne sobre o objetivo de a pesquisa geográfica fornecer descrição e interpretação precisa da superfície da Terra, Harvey (1974, p.101) coloca a importância da análise de áreas, da gênese das formas culturais, mas, mais do que isso, compreender os processos da mudança no espaço e no tempo, sendo o tempo uma dimensão negligenciada pelos geógrafos anglo-saxônicos, falha atribuída a Hartshorne por Sauer (ibidem, p.102). Contudo, a ligação entre tempo e espaço foi uma característica marcante na escola de cunho determinista originada em Ratzel, especialmente pelo uso de "zonas e estratos", ainda que de forma bastante ingênua; geógrafos alemães focaram o desenvolvimento da paisagem no tempo, que seria aperfeiçoado por Sauer e a "Escola de Berkeley"; em França, a permanência da dimensão tempo se manteve forte, especialmente, pela relação simbiótica entre o homem e a terra durante um longo período de tempo, pelo que primava a geografia francesa (ibidem, p.102).

3 Tradução do autor: "sem teorias explicativas o cognitivo e a descrição dos acontecimentos geográficos são inconcebíveis".

4 Contida na tradução para o português: Modelos integrados em geografia. 
A menção que Harvey faz a esses estudos é para demonstrar que esses são na melhor das hipóteses metáforas, mas que podem acarretar em seu lado negativo a falsas analogias, e o pior que vem a seguir: a forma pela qual são moldadas essas metáforas parece impedir o julgamento objetivo (ibidem, p.103). E é nesse ponto que Harvey (ibidem) é mordaz para com aqueles que não julgam ser importante os critérios de ciência, é preciso fazer uma escolha:

pode enterrar a cabeça como o avestruz nos grãos de areia de uma história humana ideográfica, conduzida sobre o espaço geográfico único, carregar o cenho devido a generalização ampla e produzir uma tese descritiva magistral sobre o que aconteceu, quando e onde. Ou pode tornar-se um cientista e tentar, pelos procedimentos normais da investigação científica, verificar, rejeitar ou modificar as ideias estimulantes e excitantes com que seus predecessores o presentearam.

Deixando de lado, portanto, os avestruzes, Harvey busca demonstrar qual é o "salto" explicativo entre os estudos mais "metafóricos" até o início do século, com aqueles posteriores, mais preocupados na coesão dos enunciados e mais próximos à complexidade da realidade. Era preciso testar adequadamente as teorias e, assim, em dado momento, era preciso uma formalização, um trato hipotético e uma disposição lógica, dessa maneira, os procedimentos científicos poderiam ser feitos, testes e modificações de hipóteses tornar-se-iam possíveis para explicar a evolução dos sistemas espaciais, "a maneira mais adequada de aperfeiçoar essa estrutura lógica é aperfeiçoar algum modelo elaborado da realidade que expresse as noções contidas na teoria" (ibidem, p.104). Será nos modelos que Harvey encontrará esse elemento.

Modelos mais simples ou de maior cunho descritivo poderiam tornar-se modelos operacionais mais consistentes, seja por princípios lógicos, seja pela poderosa ferramenta algébrica, nas palavras de Harvey (1974, p.104). Harvey faz, então, toda uma explicação de construção de um modelo padrão simples ideal, e aponta que, em 
razão da complexidade dos fenômenos, seria ingenuidade esperar grandes predições desse modelo, sendo o mais desejável compor sistemas de modelos, em que determinadas saídas seriam entradas em outros modelos alimentando sistemas altamente complexos.

São apresentados em seguida diversas classes de modelos com suas respectivas expressões espaciais, modelos uniformes, aleatórios, competitivos, contagiosos. Harvey (1974, p.106-7) chama a atenção para as qualidades métricas do tempo e do espaço, que podem ser ilusórias se não forem tratadas com cuidado, exigindo até uma completa compreensão da natureza do tempo e do espaço. Sucessivas formas de modelagem são apresentadas, desde séries temporais até modelos que exigem maior formulação matemática, mantendo a sapiência de que "nenhum modelo único explica a realidade exclusivamente a não ser, é claro, a própria realidade. Podemos, assim, construir frequentemente vários modelos bastante diferentes para explicar a mesma realidade e cada um deles poderia ser igualmente bom" (ibidem, p.138-9).

Os germens para a criação consistente de Explanation in Geography já se encontravam presentes nesse capítulo do livro que o antecedeu, como se pode observar até aqui. É interessante reproduzir a seguir as ideias que permeavam a concepção de ciência que Harvey (1974, p.146) havia sistematizado até fins da década de 1960:

Não estamos dourando a pílula de uma simples declaração elegante em jargão científico, mas tentando verdadeiramente desnudar os elementos da realidade que por muito tempo permaneceram ocultos ao nosso olhar. Acima de tudo, chegamos a compreender que precisamos, cada vez mais, dos modelos para nos ajudar em nossa tentaiva de compreender os princípios que governam a organização humana do espaço. Um modelo é "um artifício pragmático" para ser usado livremente enquanto servir ao seu propósito, para ser posto fora sem remorso quando deixa de fazê-lo. O cientista, portanto, se for completamente um cientista, é o único entre os usuários de metáforas por não se tornar "viciado" numa forma particular de compreender. (Rapoport, 1953, p.206) 
É possível extrair algumas considerações a respeito dessas concepções. Primeiramente, "compreender os princípios que governam" é uma típica postura que está alinhada tanto ao "espírito positivista" quanto ao "espírito historicista", um momento da história da ciência repleto de controversas e caminhos obscurantistas; em um segundo momento, a menção a uma "organização humana do espaço" pode ser vista como uma salutar contribuição para um objeto de estudo que caracterize a geografia. Por fim, nem tudo está perdido no campo da filosofia da ciência! Harvey, da forma como cita Rapoport, deixa transparecer que reconhece o critério demarcador da falseabilidade, deve-se sempre buscar eliminar o erro, aquele que o reconhece pode propor novas teorias com um poder de explicação mais completo que as que a precederam.

\section{Estrutura e conteúdo da obra Explanation in Geography: a geografia se consolidando como ciência}

A obra está dividida em seis partes, totalizando 24 capítulos em 486 páginas, em um trabalho de fôlego, que apenas pela estrutura "física" já demonstra um vigor e uma tendência ao detalhamento explicativo. As partes estão divididas na forma de grandes blocos que estruturam o pensamento científico e a forma de se realizar uma explicação em ciência, e mais especificamente dentro do campo geográfico: (i) sendo a primeira parte dedicada à filosofia e à necessidade de explicação; (ii) a segunda parte dedicada ao pano de fundo metodológico e a explicação em geografia; (iii) a terceira, ao papel das teorias, leis e modelos na explicação geográfica; (iv) a quarta, à linguagem de modelos para a explicação geográfica; (v) a quinta, aos modelos para descrições em geografia; (vi) e por fim, a sexta parte trata dos modelos para explicações em geografia.

O enfoque maior de Explanation não poderia ser outro que não fosse a explicação. Mas um tipo especial de explicação, a que Harvey (1969, p.13) se propõe a debater, indagando e apresentando uma 
construção racional do que significa uma explicação, que seria definida como "an explanation may be regarded as making an unexpected outcome an expected outcome, of making a curious event seem natural or normal", ${ }^{5}$ porque pode ser mostrado para ser gerado por processos similares e em condições semelhantes às dos eventos anteriores do mesmo tipo. Harvey segue mostrando que existem três caminhos para isso: (i) a aproximação dedutivo-preditiva (provavelmente o mais importante); (ii) a visão relacional (como a ligação dos planetas e das maçãs caindo pela lei da gravidade); e (iii) por analogia.

Pode-se perceber seu empenho em buscar na filosofia da ciência elementos que auxiliem na resposta da aquisição do conhecimento, $e$ para isso Harvey debruça-se sobre os filósofos da linha do empirismo lógico, como Richard Braithwaite, Rudolph Carnap, Carl Hempel e Ernest Nagel. No índice de autores, as chamadas desses respectivos nomes mostram grande número de citações. Outra referência muito citada e com desenvolvimento ao longo dos capítulos que tratam da explicação nas ciências naturais (capítulo 4) e na ciência social e história (capítulo 5) é Karl Popper, em que é colocado um dos elementos importantes do racionalismo crítico, a falseabilidade.

Fica evidente, portanto, que a forma de explicação especial que Harvey quer colocar é a "explicação racional", a explicação científica: declarações verificáveis por outros, porque os procedimentos envolvidos na sua produção podem ser repetidos e/ou estão abertos a testes. A estrutura do livro importa-se em desenvolver " a hard inner core of methodology - the analysis of explanation as a formal procedure - and a rather more general outer zone concerned with philosophy, speculation, perception, images, and the like" 6 (Harvey, 1969, p.23).

Há uma clara distinção entre o modo indutivo, apresentado como "caminho baconiano", e o dedutivo, que mostra a percepção que o

5 Tradução do autor: "uma explicação pode ser considerada como fazer de um resultado inesperado um resultado esperado, fazer um evento curioso parecer um evento natural ou normal".

6 Tradução do autor: "o núcleo duro interno da metodologia - a análise da explicação como um procedimento formal - e uma zona um pouco mais geral preocupada com a filosofia, a especulação, a percepção, imagens e similares". 
pesquisador tem do mundo, formulando hipóteses para que sejam validadas e conseguindo o status de leis e teorias, sintetizando o conhecimento adquirido e propiciando a construção de modelos da realidade. Esse trecho da obra é largamente reproduzido, especialmente por meio dos esquemas contidos na página 34. O problema com a disciplina, para Harvey, não são as perguntas que os geógrafos fazem, mas a metodologia que utilizam para respondê-las (Johnston, 2008). É importante notar que Harvey não vê distinção entre as estruturas metodológicas das chamadas "geografia física" e "geografia humana”, uma vez que ambas são parte da ciência, e por conseguinte, devem seguir a linguagem do método científico.

A formulação teórica é quesito fundamental e foi uma contribuição importante à forma com que Harvey coloca essa questão. Mas somente ela em si não seria suficiente para colocar em prática a pesquisa científica, e por isso que Harvey parte para a execução da pesquisa, a forma com a qual as teorias podem ser expressadas.

Primeiramente, essa resposta é dada pela matemática; em última instância a teoria requer o uso da linguagem matemática "a linguagem da ciência", nas palavras de Harvey (1969, p.179) e somente com essa linguagem podem ser tratadas as interações complexas de forma consistente (ibidem, p.76). Da linguagem matemática resultam dois campos pertinentes aos estudos geográficos: (i) a geometria, como a língua de forma espacial da geografia (a ser definida como o estudo dos "objetos e eventos no espaço" - p.191), e a (ii) probabilidade, da qual a linguagem da possibilidade é necessariamente usada. Isso se deve ao fato de que existe um mundo controlado por leis precisas e bem definidas, por meio da lógica formal; no entanto, existe um mundo empírico, irregular e caótico, que necessita de medições e verificações; esse mundo é "governado por processos imutáveis", onde a previsão precisa raramente é possível, sobretudo dada a extensão de nossa ignorância sobre esses processos, sendo muito mais conveniente seguir uma teoria probabilística do que qualquer outra teoria (ibidem, p.260). A geografia científica não será uma geografia determinista por isso, mas sim, inclui declarações probabilísticas de explicações prováveis, daí o uso de estatísticas na avaliação de hipóteses. 
A tarefa de verificação é avaliar a relação entre o observado no mundo empírico e o mundo abstrato teórico. Isso nunca é fácil, mas, se as regras são aplicadas com êxito, a explicação é alcançada; essas características transformam meras especulações em teorias científicas, elas representam um infalível método, segui-las, diz Harvey, é o sucesso garantido, conforme aponta Barnes (2006, p.33).

Uma importante contribuição é dada quanto ao uso de modelos em geografia. Harvey dedica duas seções do livro à modelagem em geografia: os modelos de cunho descritivo (Parte V), e modelos de cunho explicativo (Parte VI), dando continuidade e aprofundando o tema que tratou em seu capítulo sobre modelos publicado no livro Models in Geography (Harvey, 1974). Esses são, com efeito, os capítulos sobre o método: o primeiro tipo de modelo trata de uma medição e como retratar o mundo, como coletar as informações, classificá-las e exibi-las; o segundo tipo mostra os procedimentos para testes de hipóteses de causa e efeito, mostrando ainda a visão em sistemas, tanto como uma teoria geral quanto na forma de análise de sistemas.

\section{Reflexão}

Podemos traçar uma reflexão no campo político. A chegada do Partido Trabalhista Britânico ao poder tem certa correlação com a referida obra de Harvey. Apesar do caráter estritamente didático, e da postura, em princípio, apolítica e "neutra" que permeia toda a obra, bem diferenciada dos demais livros do autor que irão suceder Explanation, está latente, ainda que oculta, a grande contribuição que Harvey faz à geografia, mas mais do que isso, a uma geografia pragmática que pode ter no partido de ideologia de "esquerda" o caminho pavimentado para a ação, que vise construir uma sociedade mais igualitária, diminuindo as diferenças regionais e utilizando todo rigor e precisão científica para engendrar uma engenharia social. Essa visão nos é oferecida por Barnes (2006, p.34):

Cambridge was populated by an intellectual elite, and if something was seriously wrong with the state of Britain (and many thought there 
was), then this elite was surely in a position to do something about it. The modernization of Britain was firmly on the agenda, and a new structure of knowledge and power was needed to accomplish that task. Explanation did not attempt single- handedly to modernize Britain. But it provided a "new structure of knowledge" to a hitherto unbending and conservative discipline, geography, which like Britain in the late 1950s and early 1960s was in desperate need of shaking off the confining shackles of its past and modernizing. Harvey, as part of that Cambridge intellectual elite, was "in a position to do something about it", which he did. As he says, there was "the idea that we could break out of tradition. There was a modern geography waiting to be constructed and we were the ones who could do it". ${ }^{7}$

$\mathrm{O}$ instrumental oferecido em Explanation pode sustentar vários tipos de ideologia servindo de geografia pragmática tanto para governos ditos de "esquerda" ou de "direita", e isso pode ser observado nas palavras de Barnes (2006, p.35), ao citar o depoimento de Harvey (2002): "For those of us involved in geography [during the 1960s], rational planning (national, regional, environmental, and urban) backed by 'scientific' methods of enquiry seemed to be the path to take". ${ }^{8}$ Isso

7 Tradução do autor: "Cambridge foi povoada por uma elite intelectual, e se havia algo de muito errado com o estado da Grã-Bretanha (e muitos pensaram que havia), então essa elite estava certamente em posição de fazer algo sobre isso. A modernização da Grã-Bretanha esteve firmemente na ordem do dia, e uma nova estrutura de conhecimento e poder era necessária para realizar essa tarefa. Explanation não tenta sozinho modernizar a Grã-Bretanha. Mas, fornece a 'nova estrutura de conhecimento' para uma disciplina inflexível e até conservadora, a geografia, que, como a Grã-Bretanha no final dos anos 1950 e início dos anos 1960, tinha uma necessidade desesperada de livrar-se dos grilhões de confinamento do seu passado e se modernizar. Harvey, como parte da intelectualidade da elite de Cambridge, estava 'em posição de fazer algo sobre isso', o que ele fez. Como ele diz, 'a ideia de que poderia romper a tradição... Houve uma geografia moderna a espera para ser construída e nós éramos os únicos que poderiam fazê-lo".

8 Tradução do autor: "Para aqueles de nós envolvidos na geografia [durante a década de 1960], o planejamento racional (nacional, regional, ambiental e urbano) apoiado pelos 'métodos' científicos de inquérito, parecia ser o caminho a se tomar". 
demonstra a "neutralidade" da ciência, mas não a do cientista e do político. Um exemplo semelhante dá-se com os avanços em física, que permitiram desenvolver as tecnologias espaciais para lançamentos de satélites, que em muito fizeram avançar as telecomunicações e a democratização do conhecimento e acesso à informação, mas que também colocaram satélites espiões e militares, que podem impor sérias restrições a liberdade individual e serem armas letais em campos de combate. Depende aí para quem o conhecimento científico é ofertado, e quais os reais anseios de quem direciona os investimentos (política representando a sociedade).

O problema reside no fato de esse instrumental científico ser utilizado de maneira a colocar em prática uma engenharia social totalitária, antidemocrática. Os perigos e desastres desse tipo de política puderam ser vistos ao longo do século XX, com regimes totalitários de "direita" e de "esquerda". Um cientificismo exagerado, calcado em filosofias díspares como o positivismo e o historicismo, acarretou em malefícios comuns e em sérios dogmatismos, como crenças em "verdades" universais e absolutas que, atestadas pela "estatística" ou pela "história", promovem ações que podem ocasionar grandes desastres, tanto na sociedade como no corpo de uma disciplina.

Curiosamente, uma das críticas mais severas feitas à geografia teorética brasileira (ou sob o termo quantitativa em muitos manuais), de servir ao planejamento auxiliando um regime militar de "direita", foi justamente um dos motivos pelo qual Harvey confecciona sua obra, que é oferecer elementos ao planejamento, mas no caso dele, a um governo de ideologia política e afeita ao poder antagônica ao que se tinha no Brasil; ideologias díspares, mas perspectivas de intervenção comuns.

A planificação possível e a engenharia social intervencionista no espaço propiciada pelos aparatos positivistas sob seu ideal de comprovação de verdade via matematização e modelagens determinísticas são completamente antagônicas a um ideal de liberdade. A crítica feita ao positivismo em geografia, especialmente no Brasil, talvez tenha pecado em coadunar positivismo e um suposto capitalismo 
liberal, seja por ingenuidade, seja por ignorância, pois, em princípio, o positivismo serviu muito mais a ideologias de intervenção, aqui via um Estado militar totalitário de "direita", na Inglaterra via um partido social-democrata, e pode-se até colocar na União Soviética, via um Estado totalitário de "esquerda".

Harvey nos dá o retrato de um cientista plural, que caminhou por vários momentos históricos e de muitos atritos, mas que soube pesar a contribuição que cada modelo teórico/filosófico pode proporcionar de acordo com o viés de estudo que se propõe e que cada um desses pode, a seu modo, contribuir para a aquisição do conhecimento. Desse modo, em termos do corpus teórico da disciplina, Explanation mostra o empenho do singular geógrafo David Harvey em buscar sintetizar e colocar a disposição da geografia toda uma discussão fervorosa do período 1950-1970, e que consistia em uma ampla revisão e reestruturação do pensamento geográfico e de sua epistemologia, mudando completamente o quadro dessa disciplina para as gerações futuras de geógrafos.

Um bom contexto, sobre o papel desempenhado por Explanation no momento em que foi lançado e os caminhos futuros que David Harvey percorreu, é apresentado por Johnston (2008):

But Harvey abandoned his generation - or many of them - for an alternative project, to which he attracted a new generation of converts. Indeed, according to his autobiographical essay, in some ways he abandoned the first project long before he completed it - having a "lust to wander and diverge, to challenge authority, to get off the beaten path of knowledge into something different, to explore the wild recesses of the imagination as well as of the world" (Harvey, 2002, p.167). He did finish it, however, but responded to Stephen Gale's (1971) review by saying that he was at a disadvantage because Gale had read the book and "I have never read it. What is more, I have no intention of doing so now". Explanation was behind him, but remains a permanent and potent reminder of a crucial decade in geography's turbulent recent history; extremely influential when published, as not only a pioneering exploration of 'scientific method' and its philoso- 
phical underpinnings but also one of the first substantive geographical engagements with the social sciences. ${ }^{9}$

Harvey é singular na medida em que pode ser colocado como um dos poucos geógrafos que estiveram de corpo e alma envolvidos em três momentos cruciais e decisivos da geografia, na Revolução Quantitativa, na Renovação Crítica e na Virada Cultural. Estudar cada um desses momentos históricos, ou mesmo se aprofundar em cada uma dessas linhas teóricas implica, em dado momento, adentrar alguma obra de David Harvey, que no caso específico aqui tratado marca referência obrigatória nos estudos teoréticosquantitativos com a obra Explanation in Geography.

David Harvey raras vezes retornou a seu primeiro livro, o conteúdo não foi revisado nas poucas novas edições, sua mudança para uma geografia crítica ocorreu em curto período de tempo, com o lançamento já em 1973 de Social Justice and the City, que mesclava elementos da teoria marxista com alguns pressupostos neoclássicos. Daí por diante, o Harvey da "revolução quantitativa" deu lugar ao Harvey militante do materialismo-dialético, e posteriormente ao Harvey dos "espaços da esperança”. Mas, sem dúvida, indepen-

9 Tradução do autor: "Mas Harvey abandonou sua geração - ou muitos deles para um projeto alternativo, para qual ele atraiu uma nova geração de convertidos. Com efeito, de acordo com seu ensaio autobiográfico, de certa forma ele abandonou o primeiro projeto muito antes de tê-lo completado - com um 'desejo de vagar e divergir, para desafiar a autoridade, para sair do caminho batido do conhecimento em algo diferente, para explorar os recantos selvagens da imaginação, bem como do mundo' (Harvey, 2002, p.167). Ele o terminou, entretanto, mas respondeu a revisão de Stephen Gale (1971)*, dizendo que ele estava em desvantagem porque Gale tinha lido o livro e 'Eu nunca o li. Além do mais, não tenho intenção de fazê-lo agora'. Explanation estava atrás dele, mas continua a ser um lembrete permanente e potente de uma década crucial na turbulenta história recente da geografia; extremamente influente quando publicado, não apenas como um pioneiro da exploração do 'método científico' e os seus fundamentos filosóficos, mas também um dos substanciais compromissos geográficos para com as ciências sociais" [* O texto mencionado de Stephen Gale é: On the heterodoxy of explanation: a review of David Harvey's Explanation in Geography. Geographical Analysis n.3, p.285-322]. 
dentemente do caminho trilhado, Explanation figura ao lado das grandes obras teoréticas da década de 1960 e 1970, marco referencial para estudos do empirismo lógico, da lógica formal e da forma de explicação científica em geografia. Obra e autor certamente terão seu reconhecimento no corpo histórico e teórico da disciplina Geografia.

\section{Referências}

BARNES, T. Quantitative revolution (Geography of). In: KITCHING, R; THRIFT, N. The International Encyclopaedia of Human Geography. Oxford: Elsevier (no prelo). Disponível em: <http://www.geog.ubc. $\mathrm{ca} /$ tbarnes/pdf/Quant\%20Revolution.pdf>. Acesso em: 16 mar. 2010 .

Between deduction and dialectics: David Harvey on knowledge. In: CASTREE, N; GREGORY, D. (Org.) David Harvey: a critical reader. Oxford: Blackwell, 2006, p.26-46.

BERRY, B.; GARRISON, W. L. The functional bases of the central place hierarchy. Economic Geography, n.34, p.145-54, 1958.

BUNGE, W. Theoretical Geography. Lund Studies in Geography. Series C: General and Mathematical Geography. Lund: Gleerup First Edition, 1962.

BURTON, I. The quantitative revolution and theoretical geography. $\mathrm{Ca}$ nadian Geography, n.7, p.151-2, 1963.

CHORLEY, R. J; HAGGETT, P. Models in Geography. London: Methuen, 1967.

GARRISON, W. L. et al. Studies of Highway Development and Geographic Change. New York: Greenwood Press, 1959.

GOLLEDGE, R. G.; AMEDEO, D. On laws in geography. Annals Association of the American Geographers, v.4, n.58, p.760-74, 1968.

HARVEY, D. Explanation in Geography. London: Edward Arnold, 1969. Modelos da evolução dos padrões espaciais na geografia humana. In: CHORLEY, R. J.; HAGGETT, P. Modelos integrados em geografia. São Paulo: Edusp, 1974.

JOHNSTON, R. David Harvey "Explanation in Geography”. In: HUBBARD, P. et al. Key Texts in Human Geography. London: Sage, 2008.

PATERSON, J. L. David Harvey's Geography. New Jersey: Barnes and Noble Books, 1984. 
ULLMAN, E. L. The Basic-Service Ratio and the Areal Support of Cities. Proceedings, Western Committee on Regional Economic Analysis, Social Science Research Council, Berkeley, p.110-23, 1953.

. The Role of Transportation and the Bases for Interaction. In: . Man's Role in Changing the Face of the Earth. Chicaga: Wenner-Gren Foundation for Anthropological Research and the National Science Foundation, University of Chicago Press, 1956, p.862-80. 


\section{6 \\ Quinze BONS ARguMENTOS CONTRA A GEOGRAFIA TEORÉTICA; QUATORZE CONTRA-ARGUMENTOS MELHORES AINDA (OU QUANDO O QUANTITATIVO NADA QUER DIZER)}

Dante F. C. Reis Junior ${ }^{*}$

\section{Introdução}

Neste capítulo, nosso interesseé sumariar um instigante episódio de controvérsia ocorrido na História do Pensamento Geográfico entre três e quatro décadas atrás. Não se trata, sinceramente, de ressuscitar um debate que, em certas circunstâncias, esteve por demais influenciado por moções apaixonadas (portanto, às vezes bastante intestinais, e pouco equilibradas). A intenção é divulgar o inventário que fizemos a respeito das apologias e senões referentes à corrente de pensamento denominada "Geografia Teorética e Quantitativa" (GTQ), sintetizando as espécies de argumento numa e noutra direção. Com a amostra, desejamos apenas instigar o exercício (que nos parece pedagógico, além de epistemológico) do examine pessoal - segundo, pois, critérios e "inclinações" que cada leitor geógrafo há de possuir - da consistência e da coerência constantes tanto das censuras quanto das defesas. (Entendendo aqui que coerência teria a ver com uma construção não contraditória do argumento - um fator "endógeno", digamos assim -; enquanto sua consistência se

* Professor adjunto do Departamento de Geografia, Universidade de Brasília $(\mathrm{UnB})$. 
reportaria ao potencial de resistir a um confronto com argumentos outros - já um fator “exógeno", então.)

Os argumentos contrários e os contra-argumentos foram principalmente extraídos de oito publicações sintomáticas. São quatro para cada uma das duas "trincheiras"... e, em cada quadra de autores, sempre uma dupla estrangeira e uma dupla doméstica. Selecionamos para a quadra crítica: David Harvey (1972) ("Revolutionary and counter revolutionary theory in geography and the problem of ghetto formation") e Michael Hurst (1973) ("Establishment geography: or how to be irrelevant in three easy lessons"), da cena internacional, e Milton Santos (1978) (Por uma geografia nova: da crítica da geografia a uma geografia crítica) e Manuel C. de Andrade (1987) (Geografia, ciência da sociedade: uma introdução à análise do pensamento geográfico), da cena doméstica. E para a quadra de contra-argumentadores optamos por: Brian Berry (1972) ("Revolutionary and counter revolutionary theory in geography" - a ghetto commentary") e Reginald Golledge (1973) ("Some issues related to the search for geographical knowledge"), no argumento alienígena, e Antonio Christofoletti (1976) (“As características da nova geografia”) e Speridião Faissol (1987) ("A geografia na década de 80; os velhos dilemas e as novas soluções”), no argumento indígena.

Outro motivo para a redação deste capítulo deve-se ao fato de na literatura historiográfica corrente ser mais costumeiro apresentar as escolas de pensamento segundo um modelo de progressão evolutiva linear. É que, em virtude disso, com frequência a descrição delas se dá ali seguindo o esquema: "escola $x$ (características gerais) $\rightarrow$ (deficiências/deméritos $) \rightarrow$ (esgotamento/ruína) $\rightarrow$ escola $y$...". Sendo assim, é de esperar que quaisquer vantagens circunstanciais e predicados relativos sejam apresentados numa etapa interpretativa preliminar; $\mathrm{e}$ suas "imperfeições" (presumidamente, aquilo que teria motivado seu gradativo descrédito) numa etapa de desfecho descritivo. Raramente, na processualística historiográfica, somos informados das réplicas ou contestações... feitas, decerto, por aqueles que se engajaram no pensamento repreendido. Eé por essa razão que nosso capítulo está organizado numa estrutura "invertida"; ou seja, primeiramente são 
apresentados os argumentos opositores ("argumentos contra") e em seguida formas de discurso apologético ("contra-argumentos").

Ainda no plano da organização, optamos por, quando imprescindível, referenciar a explícita fonte autoral do argumento (por exemplo, quando certas terminologias ou expressões são transcritas na sua forma literal) utilizando uma notação simbólica mais abreviada. Ex: "[Gol:63]", para indicar que a argumentação recém-exposta (ipsis litteris ou noutras palavras) é possível de encontrar na página 63 do artigo de Reginald Golledge. Na ausência, porém, de referência à fonte precisa, isso quererá dizer que a construção do argumento se deu a partir de noções que só constam das referências autorais na forma de pistas ou rastros - mas, ainda assim, perceptíveis... como que pairando sobre argumentos genuínos.

Algumas vezes também grifamos (com um sublinhado) determinadas expressões $-e$ justamente porque nos pareceram merecer o destaque de uma ideia paramétrica naquele preciso trecho.

Talvez seja possível notar, certos argumentos guardam entre si suficiente parecença... e poderiam, desse modo, figurar fundidos. Nesses casos, os dispusemos disjuntos porque quisemos frisar, dos mesmos, alguma peculiaridade que só seria possível dar o devido destaque se os segregássemos em intitulações desmembradas. Estará, por certo, igualmente visível o fato de dados argumentos, extraídos de textos publicados por autores de um dos fronts, poderem servir de ilustração do argumento antagonista. Isso acontece porque os autores que porventura se sentiram implicados no reproche, em suas reflexões a posteriori tiveram uma atitude do tipo mea culpa e, nesse sentido, não se furtaram a enumerar as insuficiências que eles próprios reconheceram terem sido letais à causa teorética.

Por fim, convém lembrar que é lamentavelmente comum (embora jocoso) os contra-argumentos não responderem com primor aos "insultos" [sic] sofridos. Poderíamos aqui dizer que haveria, inclusive, três maneiras principais de contra-argumentar: $1^{a}$ ) a "impecável" (desconstruindo o julgamento no seu exato âmago); $2^{\mathrm{a}}$ ) a "evasiva" (simplesmente tergiversando... e, em geral, optando por acusar os defeitos do adversário); ou $3^{\text {a }}$ ) a "ufanista" (na verdade também uma 
forma de tergiversação, só que não recorrendo à tática ofensiva; em vez disso, preferindo fazer sobressair os melhores predicados).

Mas deixaremos que o leitor as diagnostique, autonomamente, a partir de agora.

\section{Argumentos contra}

$1^{\circ}$ : A transição old geography (do qualitativo, do único) para new geography (do quantitativo, do geral) traduz-se por uma language turn em que o argumento (deliberadamente) torna-se "difícil"; e essa deriva significou, ademais, luta por poder e status, além de uma pronta resposta a pressões e demandas maquiavelicamente arquitetadas.

A GTQ significou ampliação da capacidade de manipular/ controlar (uma prerrogativa da classe que, por sinal, também tende a ser a que define aquilo que precisa ser manipulado/controlado). A "classe" compõe-se, por exemplo, de empresários capitalistas (daí a conclusão que a atividade científica subordina-se àqueles que controlam os meios de produção).

À parte todo ideário difundido de desafio e necessidade de sobrepujar debilidades metodológicas, o "movimento quantitativo" foi, na verdade, "contrarrevolucionário", pois não rompeu com o establishment. O velho permanecia velho; apenas teria vestido novos trajes conceituais (às vezes confusos, aliás). E aquela manipulação/ controle, em se tratando de "ciências sociais", naturalmente dirige-se a um objeto feito de atividades humanas. (Essas, portanto, deviam ser executadas por arreios.)

As "demandas" eram (são?) por uma "nova organização da economia" [San:73], devidamente atrelada a um virtual "novo período da história do capitalismo" [San:74]. "Suportes do trabalho científico" evoluíram em sintonia com a "necessidade dos utilizadores" [San:39].

E se na verdade não se pode negar a direta influência da estrutura social sobre o "processamento de teorias e dados", a questão nem chegava a ser exatamente a se teriam sido logicamente válidos 
os modelos, mas se devíamos tê-los aceito só porque uma nata de pesquisadores os tinha desenvolvido.

Estes pesquisadores teriam ostentado uma honraria: a glória de terem sido os que dominavam habilmente uma "nova linguagem" (na prática, aparentando ser só deles). Demonstrava-se, assim, todo o poder de uma ideologia tecnocrática.

Ademais, a G, se próxima de uma "ciência natural", justifica sua cooptação pelos interesses de grupos privilegiados, pois que, tradicional e historicamente, apesar das naturais "resolverem" questões advindas do complexo social, não introjetam nelas mesmas a ordem de fenômenos nele inscritos; o ideal é "socializar" as naturais, a fim de "realizar o potencial humano"... isso, em vez de insistir nas manipulações e controles. E para "realizar o potencial humano" só mesmo uma "mudança social humanizadora" [Har:6,11].

Aliás, a GTQ teria identificado eventos de baixa relevância, dado que parece ter, nesse feito, omitido a estrutura social da disciplina. Bem, então o fato só pode mesmo nos desautorizar o uso do termo "revolução". A GTQ só conseguia "se pretender" revolucionária (isto é, pretensamente rompendo de vez com as tradições); no entanto, o tempo mostrou que se tratava de uma contrarrevolução, já que apenas auxiliara os desígnios da exploração econômica.

A GTQ emerge de um contexto grandemente favorecedor/ demandante de disciplinas preferencialmente "aplicadas". A "Geografia Ativa", contemporânea da GTQ, foi a versão francesa de uma evolução metodológica que teria havido no âmbito da tradição clássica. ("Teria", realmente... pois tal qual o caso da GTQ, a GA não a negou de fato.)

$2^{\circ}$ : Se a verdade é o que é dado (o fato de haver iniquidade espacial, por exemplo), o (neo)positivismo tenderá a resolver o fato dentro do mecanismo que gera o próprio fato... entendendo-o como "indicação de desequilíbrio" ou "desvio do modelo normativo".

Necessário seria exterminar aquilo que torna válido o modelo reivindicar mecanismo de "controle socializado"... e formular possíveis alternativas de ação. 
A abordagem (neo)positivista opera com lógica binária "verdadeiro/falso" (enquanto a dialética, cobrindo eventos mais complexos, prevê a interpenetração dos oposto-contraditórios e a "verdade" desta síntese vigora temporariamente apenas).

Como exemplos de "contradição": a economia de mercado dependendo de escassez; a "perpetuação do capitalismo" precisando (estruturalmente) de "condições sociais deterioradas" (e aqui o papel das conexões institucionais) [Har:8,10].

$\mathrm{O}$ (neo)positivismo (ainda incrustado na $\mathrm{G}$ ) contribuía a endossar o status quo-esse, grandemente legitimado pelo sistema educacional e pela mentalidade prática. Nesse sentido, se exercícios mecânicos ocupavam privilegiadamente o rol das práticas, marginalizava-se o trabalho com dimensões subjetivas.

O "mecânico" tinha muito a ver com o ser contrário a toda sorte de value-judgement [Hur:42].

E o sistema educacional aparentava ser o replicador-mor de mitos e valores individualistas.

A "marginalização" teria se verificado à medida que um "cientismo receitante" [Hur:41] militava contra uma G socialmente interessada, portanto envolvida com os problemas contemporâneos.

$3^{\text {o }}$ : (Mais além da imediata aparência): Não se conseguiu, com a GTQ, produzir leis; apenas descrições mais exatas (em análise regional), mas, ainda assim, sem grande valor explicativo... e mesmo considerando modelos matemáticos de representação de padrões complexos, os "processos de fundo" lhes escapavam.

E um exemplo categórico: o fato das "matérias" e/ou "energias", na realidade, se difundirem heterogeneamente (conforme o grau de acessibilidade oportunizado pelo estrato social a que pertencem os potenciais usuários).

As "descrições exatas" respondem, essencialmente, a uma orientação técnica - o que é muito pouco para representar cientificidade.

Nem sempre o mecanismo previsto pelo modelo se identificava com aquele que efetivamente desencadeia os fatos observados... e 
por mais que esses estivessem de acordo com a estrutura teórica do modelo. As teorias locacionais, nesse sentido, deveriam ter sido capazes de propor "futuros melhores" [Har:11], mediante revelação/ ruptura de/com o modo pelo qual a produção vinha sendo organizada (para criar surplus value).

O mecanismo previsto pelo modelo, propondo uma causalidade muito evidente, economizava a reflexão sobre processos desencadeadores mais profundos. O fenômeno da "favelização", por exemplo, seria de fato um efeito de expansão demográfica? Não seria, melhor dizendo, sequela de atração urbana? [San:63].

Houve, pois, discrepância entre toda a sofisticação teórico-metodológica e a significância explanatória; o real produto obtido dissentia da presunção explicativa... e ele, não contemplando as "condições sociais objetivas”, não tinha como enfrentá-las. $O$ (neo)positivismo até procura entender essas "condições sociais objetivas" [Har:6], mas acontece que não opera no sentido de mudá-las. No lugar disso, não sobra mais que uma análise (de fato) rigorosa (mas) de "suposições muito triviais" [Har:3].

$4^{\circ}$ : (Estratagema, quase maquiavelismo): As premissas dos modelos são por demais simplificadoras (todos são consumidores, produtor e consumidor detêm racionalidade e informação etc.); "verdades sociais" (tais como a exclusão racial) eram omitidas por uma estrutura de linguagem; e por força da entronização de um empiricismo abstrato, dados bons podiam terminar sacrificados, só para que o modelo não fosse desmentido.

O enfraquecimento do empiricismo tradicional (aquele praticado no campo, nas excursões) significou o fortalecimento da análise laboratorial. Parecera "desnecessária a observação da realidade" [And:107]. Demasiada confiança nos postulados contidos em protótipos teóricos fazia, então, os usuários propenderem para a omissão de outros ângulos - aqueles não contemplados pelo modelo abstrato.

Consequentemente, instrumentos técnicos, tais como os "feasibility reports", transmitindo ideia de racionalidade político-econômica 
(planejamento eficiente do desenvolvimento), encobriam ações imorais. Sumariando o ápice dessas ações, a exploração desenfreada de riquezas materiais e de forças de trabalho. E o "encobrimento" disso funcionava no preciso fito de pôr sob os holofotes a chamada "urgência econômica"... com isso, disfarçando os custos sociais e ambientais. Estava claro que uma particular simbiose monopolizava a atenção: aquela que amarrava os valores materiais de uma vida destinada ao consumo com o funcionamento estratégico de toda a estrutura de produção.

A sofisticação linguística não mais que prefigurava um "debate de fundo", uma "querela de vocabulário" [San:92] ... avalizada, ademais, pela "mobilização" dos quadros universitários [And:103]. O "planejamento eficiente" queria dizer, por exemplo, "localização ótima" - ao final, desígnio e meta objetiva do desígnio estavam de acordo com uma ideologia. Não haveria distorções (em transporte, preferência e aquisição), nem tampouco tensões decorrentes.

Levada ao extremo, a GTQ transformaria o geógrafo de técnico (coisa já condenável, se numa condição exclusiva) em "tecnocrata".

$5^{\circ}$ : (Estratagema, quase maquiavelismo 2): $O$ elenco de análises estatístico-matemáticas eram endossadas pelos estratos mais interessados no diagnóstico que elas poderiam produzir.

Eram indústrias, agências, representantes de uma visão de mundo que estavam (estão) profundamente associados ao ideário da plena concentração de poder.

Tais análises são, dentro do sistema capitalista, "funções maximizadoras"... do lucro, da competição. Parecem legitimar, então, os "pressupostos capitalistas de comportamento de firma" [Fai:13], como o lucro, a propriedade privada, a iniciativa de particulares. Por este raciocínio, a única "minimização" imaginável era a que fizesse reduzir os custos [Fai:29].

As visões de mundo são "valores perpetrados pelo sistema capitalista" [Hur:43], "ideias feitas, sem as quais os novos modelos econômicos não poderiam vingar" [San:74], "interesses do grande 
capital" [San:77] e operam para "facilitar desígnios" [San:85]. No Brasil, durante os governos militares, a visão de mundo do estrato administrativo previu a integração da economia nacional à mundial; tanto quanto o favorecimento a que se dessem intercâmbios científicos de profissionais brasileiros (do IBGE, por exemplo) com pesquisadores estrangeiros [And:109].

Numa escala internacional, os "mais interessados" à época da difusão da GTQ foram as nações anglo-saxônicas (Estados Unidos, sobretudo)... tirando partido da eficácia instrumental dos meios de comunicação [San:41] - o que só teria facilitado um "neocolonialismo intelectual" [Fai:13]. A referida difusão se deu sem que as ferramentas tivessem sido analisadas/consideradas o quanto de sintonia em valor cultural (entre as realidades) um uso apropriado exigia... para que não se configurasse "etnocentrismo" [Fai:8,13].

$6^{\mathbf{0}}$ : (Profunda, oculta, intrincada verdade): $O$ retorno que o "método científico" rende às ciências físicas não se verifica nas disciplinas cujo foco seja o homem, pois o empirismo lógico (exigente de verificação experimental ou de "verdades por definição") não se adéqua bem ao tratamento das emoções humanas - as quais, pelo método, terminam fatalmente coisificadas.

O esquema no qual se baseia a sintaxe das explanações nas hard sciences, quando empregado à risca ao tratamento do fenômeno socioespacial, desnaturava seu efetivo modo de ser... (que, na verdade, de tão intrincado, embaraça quaisquer leituras numa perspectiva mecânica ou de codificação lógica).

Relações humanas e estruturas sociais decorrem de mecanismos não tão "intuitivamente evidentes" como aqueles a partir dos quais se manifestam interações físicas ou estruturas orgânicas. E não sendo intuitivamente evidentes essas matérias, só com o enorme sacrifício do conhecimento concreto de sua realidade é que poderão ser tratadas (desfigurando-as, é claro) com hipóteses a priori. A GTQ privilegiou-as, desprezando o "empirismo concreto" - a mais plausível fonte de hipóteses, a "essência das coisas" [San:47,53,76,93]. 
$7^{\circ}$ : (Poder, aparatos e aparelhamentos): Havia uma G instituída (preservada por coerção e medidas autoritárias) que compreendia dois grandes grupos de atores: $1^{\circ}$ ) praticantes diretos ("Alto Clero", "Funcionalistas /Pragmáticos" e "Soldados") e $2^{\circ}$ ) cooptados e servidos (respectivamente, "Graduandos" e "Corporações").

No Alto Clero - "College of Cardinals" [Hur:45] - estão as personalidades reverenciadas em cerimônias; aquelas que, periodicamente, "reavaliam" os pilares teóricos. Funcionalistas/Pragmáticos - "Elite Secularists" [Hur:45] - são os que prestam serviços técnicos... aos planejadores, por exemplo. Já os Soldados - "Third Estate" [Hur:45] - compõem o núcleo dos ignorantes (ou falsoingênuos), fazendo a guarda daqueles pilares.

No segundo grupo estão tanto os "pupilos" (muitas vezes fiéissecretários dos caciques) quanto as esferas administrativas, assistidas pelos experts em instrumental técnico.

Os Soldados não são necessariamente os que propagandeiam, de modo escancarado, os valores (do empirismo lógico, por exemplo); em geral, acabam fazendo-o por vias indiretas [San:79].

O Alto Clero intimida a iniciativa crítica. Além disso, quando da "glorificação do mestre", eleva-se muito a probabilidade de que sejam deformadas as versões genuínas (tanto daquilo que se defende, quanto daquilo que se é contra) [San:85].

$8^{\circ}$ : (Poder, aparatos e aparelhamentos 2): No seio dos "praticantes diretos" verificavam-se pelo menos quatro tendências de conduta: $1^{a}$ ) "tática" (redução do homem e da paisagem a uma abstração controlável); $2^{a}$ ) "diletante" (visão menos estruturada da ciência, com resultados de pesquisa menos expressivos/úteis); $3^{a}$ ) "filistina" (paixão pelas matérias e rotinas eminentemente político-administrativas da instituição); $e$ $4^{a}$ ) "insurgente" (questionamento da estreiteza do conhecimento atual, semeando a ideia de abrir os poros da disciplina e de quebrar o pacto com as normas vigorantes).

O tático - "gamesmen" [Hur:47] - exercita vários canais de articulação com o "método científico". O diletante - "occupationalist" 
[Hur:47] - apresenta forte inclinação para as monografias. Do filisteu - "ungeographer" [Hu:47] -, mentecapto, não se deve esperar que suscite qualquer reavaliação do sistema. Já o insurgente - "marginal" [Hur:47] -, apesar de poder advertir sobre a necessidade de subverter a ordem, não sabota o status quo ... e, não raro, até se ajusta a ele. Assim, a adoção que possa fazer, de uma postura crítica, não irá superar a superficialidade [San:79].

Além daqueles semiapologistas (Soldados) e desses ofendidos superficiais (insurgentes), haveria o grupo dos "oportunistas" [San:80] - conduzidos pelo modismo das técnicas - e o dos "fanáticos" [San:80] - por sua vez, propagandistas escancarados.

$9^{\circ}$ (Poder, aparatos e aparelhamentos 3): Havia determinados instrumentos mediante os quais os "praticantes diretos" acabavam colaborando para o enraizamento do ideário corrente: $1^{\circ}$ ) os "manuais" (espécies de "Bíblia" de cada subcampo da disciplina); $2^{\circ}$ ) as "reuniões científicas" (congressos, simpósios, mormente utilizados para divulgar resultados corroborantes dos parâmetros de interesse); $3^{\circ}$ ) a "formação universitária" (estrutura dos currículos não dando ensejo ao atrevimento teórico); e $4^{\circ}$ ) "compartimentalização das pesquisas" (estrutura dos departamentos obstaculizando o intercâmbio de conhecimentos).

Os manuais - "Textbooks" [Hur:50] - veiculam exclusivamente o que garanta a manutenção de convenções/parâmetros sacralizados. São refratários à transmissão de vieses controversos e, por isso, agentes discriminatórios... já que tenderão a proibir certos assuntos e interpretações (os pontos de vista da abordagem dialética, por exemplo). E justo neste campo de ação há, igualmente, outros agentes-obstáculo: editoras, associações, agências de fomento etc. [San:86].

Nas reuniões - "Professional Meetings" [Hur:51] - sobram cortesias mútuas e alguma manifestação fortuita de "arroubos de consciência" social/ambiental; porém, os comunicadores mais noticiam que propriamente propõem. Haveria certo cinismo envolvido, então. 
Durante a graduação - "Graduate School" [Hur:52] -, os estudantes, não incitados, tendem a se aclimatar aos formalismos; daí ser fatal contentarem-se com as ferramentas disponíveis. E, vindo a adquirir expertise no seu manuseio, têm boas chances de constituir o "manpower" [Hur:54] em firmas e corporações.

Os "Departamentos" nas instituições de ensino superior - "Departmental Structure" [Hur:52] - são já uma prova do quão forte é o simulacro da "coesão via especialidade investigativa". E dada a consequente compartimentalização também das pesquisas, o "empobrecimento da interdisciplinaridade" [San:80] torna-se algo inevitável... mesmo porque a realidade (complexa que é) fica, assim, dissimulada [San:90]; ao passo que uma visão global, impossibilitada [San:91].

O "enraizamento" também se concretiza(va) na medida em que o peso do tradicionalismo joga(va) contra a máxima exploração das ideias (proeminentes) que vêm/vinham à tona. Ilustraria isso, o entrave ao aperfeiçoamento de modelos teóricos que, na melhor das hipóteses, apenas ganhavam ligeiro apuro (e, portanto, quedavam subaproveitados) - modelos tais como o dos lugares centrais, o dos polos de desenvolvimento, o da difusão de inovações... ideias, no mínimo, originais [San:42,75].

10: Só a total (e sincera) revogação do estatuto-establishment da neutralidade tornaria confiáveis as posturas socialmente comprometidas do cientista... isto é, indo além daqueles arroubos de consciência, seguidos de resignação.

Essa revogação quereria dizer sermos capazes de criticar a nós mesmos, e não apenas àquilo que testemunhamos; já que (dado o aninhamento da teoria à história) simplesmente não é possível professar revolução teórica sem que se tome parte na revolução social que ela fatalmente implica.

E porque se isentava de tomar parte em ações insurrecionais (tão logo diagnosticasse nos spatial organization patterns lógicas opressivas)-ou até as incentivava, mas no estrito âmbito de uma eloquente oratória -, o geógrafo teorético-quantitativista não passou de um alienado... ou fingido. 
$11^{\circ}$ : No afã de adquirir as qualificações da previsão e da precisão (metas recomendadas pelo cientificismo), a GTQ deixou o pensamento geográfico prisioneiro, ora da linearidade causa-efeito, ora da circularidade causa-efeito-causa.

Ambas (linearidade e circularidade) "isolam artificialmente" algumas variáveis, desfazendo as totalidades [San:57].

Os "anéis circulares" da teoria sistêmica não dão conta de explicar, por exemplo, a retroação das formas sobre os processos. $\mathrm{O}$ sistemismo não considera a natureza das partes; logo, omite que elas só irão combinar-se frutiferamente desde que dadas condições manifestem-se [San:60].

O tratamento matemático-estatístico opera de forma programada; então, o dado gerado não deve afastar-se da lógica que fundamenta o dado "entrante" [Chr:25].

Decidida a encontrar novo paradigma, a Nova Geografia assimilou acervo de modelos que pareciam, no contexto, representar o elo desejado entre conhecimento teórico e instrumentação tecnológica - modelos, em realidade, de origem positivista (alguns nitidamente organicistas). "Teoria dos Sistemas Gerais", teoria(s) da "Complexidade", "Teoria dos Jogos", "Cibernética" etc. A maioria desses modelos teóricos não autorizava senão especulações acerca da "geometrização" dos processos; jamais o verdadeiro funcionamento.

12: A GTQ instituiu o mau-hábito das medições antecipadas ao raciocínio teórico (quando este é que deveria antecedê-las).

O refinamento envolvido seduziu e mascarou o fato de ter havido tão somente melhoria no processo descritivo (dada toda a sofisticação tanto na coleta das informações, quanto na expressão dos resultados)... tratava-se, enfim, de técnica nova; não de G nova. E, mesmo assim, o "novo" em questão não teria passado de uma "sofisticação do velho lastro positivista" [San:88].

A necessária "precedência do qualitativo" reside no fato de as variáveis arroladas precisarem condizer, o máximo possível, com a realidade concreta que se quer explicar. A modelagem tendia a ser 
suspeita, porquanto formalizava suposições sobre o mundo e estas suposições eram demasiado vagas e/ou ideológicas.

O recurso à suposição é uma clara herança da filosofia idealista [San:87]. Lastimável, portanto. E sendo de natureza ideológica, funciona como "instrumento subordinado" [San:64] e tem "conotação de poder" [Fai:19].

13(A lacuna "tempo"): A GTQ, com os expedientes matemáticos, não mais que sugeria "processo em curso"; a explanação direta das sucessões não era alcançada efetivamente... senão "fotografias".

A teoria estatística, por conceito, desemboca na ideia de observações independentes.

"Fotografias" são estados, momentos discretos. E uma vez que a análise sistêmica casava-se bem com a leitura matemática, ela também negligenciava os processos, atendo-se a (e contentando-se com) as relações [San:61].

Com "esquemas congelados", aniquila-se a história, e isto é simplesmente uma "violência metodológica" [San:66]. Aniquilandoa, rotinas metodológicas mecânicas acabam sendo referendadas [San:65].

O mais coerente seria inserir "categorias historicizadas", pela quais (veiculando ideia de mutabilidade) ir aperfeiçoando a teoria. $E$ isso para não ficar refém de representações codificadas de fatos isolados (medição de coisas que não podem ser mudadas, por exemplo) [San:66].

14': Por efeito de uma abordagem do tipo ecológica, a fronteira (deduzida) ocultava a real identidade ("trans-local", em verdade) dos fenômenos internos... então, não ficava visível o quanto as interações aquém-fronteira interessavam a um sistema maior, além-fronteira.

O "sistema maior" pode nada mais ser que a imposição de um "modelo único, imposto de fora" [San:76]. (É que toda teoria espacial promulgada pela GTQ não teria conseguido - ou quisto? - transcender as abordagens isolacionistas, bem como as perspectivas neoclássicas do man-average e da superfície isotrópica.). O ângulo isola- 
cionista (por exemplo, em estudos de parques industriais regionais) só se prestava à solução expedita de problemas imediatos [San:92]. Teorias espaciais (por exemplo, sobre "pólos de desenvolvimento", de Perroux) e análises regionais (nos Estados Unidos, praticadas por Isard) ilustram a prioridade do raciocínio economicista e da técnica econométrica.

Também associada ao problema ecológico, havia a questão das correlações que, se generalizadas, mascaravam invalidades contextuais; isto é, de acordo com a escala de análise a correlação podia apontar diagnóstico diferente.

$15^{\circ}$ : A G inclinada a trabalhar com modelos do tipo probabilístico subsidiou um pensamento econômico de linhagem liberal-capitalista.

O ideário probabilístico diz de um futuro dependente do "estado das restrições"; ou seja, não imperativamente subjugado ao passado. O aleatório das decisões individuais fica, assim, contemplado; e a hipótese intrínseca de possibilidades equitativas dissolve a de que haveria "respostas" (espaciais) indefectíveis... ou, pelo menos, mais prováveis que outras - como era o caso de se supor para comunidades em situação periclitante.

(Na visão sistêmica, toda organização espacial é "uma das" respostas possíveis .. que resulta de um arranjo - muitas vezes imponderável - de restrições ambientais e de iniciativas sociais. Bem, se se consente a suposição geral do modelo, a contingência envolvida nesse processo de indivíduos/elementos agindo livremente acaba dando excessivo relevo à ideia de dinâmica estocástica... e, consequentemente, encobre-se o fato das injustiças não serem jamais efeitos acidentais.)

\section{Contra-argumentos}

$1^{\circ}$ : Apesar dos possíveis equívocos, abusos, imprecisões e/ ou privilégios, o caráter de inovação não pode ser encoberto ou omitido. 
Um exemplo de "privilégio" concedido diz respeito aos modelos quantitativos, os quais, como operadores de funções de otimização, podiam dar a impressão (mas apenas aparente) de que seriam conciliáveis precisamente com os pressupostos de um materialismo produtivista... quando, na verdade, não havia (e não há) nada que impeça um juízo algorítmico também dirigido à otimização de benefícios sociais. Assim, teoricamente, o mesmo instrumental lógico tinha como lidar também com uma meta de distribuições ótimas.

Outro exemplo relevante, agora a ver com uma falsa imprecisão, refere-se ao problema da concordância modelo-realidade. Com a constatação de que o estabelecido pelas normas do protótipo teórico não se verificava a rigor, vieram logo as reprimendas apontando como engodo a presunção dos poderes preditivos... e, numa decorrência excedida, acusando de imperfeita a teoria subjacente.

Eventual incongruência entre a previsão do modelo e o estado efetivamente observado num dado tempo não é, entretanto, o suficiente para promover a sumária refutação da estrutura teórica inteira. É que ocorria de, em se tratando de sistemas dinâmicos, o estado medido poder representar certa etapa "provisória", entre duas possibilidades (estas $\operatorname{sim}$ ) razoavelmente previstas. Além do mais, essa etapa também podia assinalar um momento transitório de perturbação, com retorno (esperado) ao estado que o modelo atribuía a probabilidade mais significante.

$2^{\circ}$ : A reivindicação de paradigmas que não omitam problemas causadores de indignação moral é feita dentro de um estilo de pensamento (ainda grandemente) "acadêmico-intelectual"... portanto, também "de classe".

Sendo assim, foi tolo sustentar que bastaria um "compromisso com a ética" para que, automaticamente, a mudança social "desejada pela maioria" se fizesse perceber.

O ideário disseminado na civilização ocidental, baseado em "busca individual por status", "tomada de decisão privada" e "determinação competitiva", confere ao ambiente um caráter que, de tão fortemente "pluralístico", torna inimaginável uma concentração 
específica de poder (sem a qual revoluções subversivas são desnecessárias). Logo, o que possa parecer (segundo teoria da conspiração) desamparo de determinados contingentes populacionais em prol da conservação de uma lógica para a qual o sucesso de uns pressupõe desgraça de outros - como um "drama sórdido" [Har:10] -, revela, na verdade, iniciativa. E iniciativa baseada na percepção de alternativas para a melhoria da condição presente. É certo que se trata de atitude individualista... e que não só está de acordo, como ratifica os valores hegemônicos do Ocidente. Mas caberia, neste caso, questionar as "regras do jogo", pois que ele, no final das contas, é jogado por todos.

$3^{\circ}$ : Era enganosa a ideia de que seriam mutuamente exclusivas as ações de: a) proceder à modelagem teórica (generalizadora), e b) engajar-se na transformação da realidade modelada... como se fosse o caso de puramente optar entre "organizar sistematicamente a informação" (sobre o que se testemunha) ou "agir politicamente para alterar a fonte" (geradora dos dados).

O caráter urgente-imperativo dos "problemas empíricos de um mundo real" [Gol:64] (sejam os da ótica das corporações, ou os da dos "pobres") não torna automaticamente um capricho a pesquisa baseada em solidez teórica... pois que ela será exatamente o fator discriminante da significância dos novos fatos (ou seja, dos dados adicionais, cuja avaliação simplesmente não se faz na ausência de parâmetro teorético).

Capricho é dissimular a função-chave do "método científico", que, no rigor e objetividade que lhe são próprios, é a de permitir, essencialmente, a identificação daquilo que - se parecer pertinente - até se poderá pretender transformar. (Aliás, contando com amparo teórico robusto e versátil, o "o quê" transformar poderia, quem sabe, ser suplementado pelo "como" -; mas, claro, entendendo que esta é uma atribuição já transcendente ao preciso papel que cabe ao método desempenhar.)

Na condição de ciência social, a G, porque se interessa em explicar a organização do espaço, não tem como se eximir de revelar (se for 
o caso) ocorrências de "injustiças territoriais" - em termos de distribuição de riquezas e oportunidades, por exemplo. Porém, é uma extrapolação irresponsável entender que, por isso, a G converte-se automaticamente numa disciplina "militante".

$4^{\circ}$ : Também eram distorcidas as assertivas indiretas, segundo as quais (omitindo o natural amplo alcance das possibilidades explanatórias em Ciência) só haveria "uma" opção possível para o discurso em ciências sociais (pretensamente, a que estaria de acordo com valores éticos consensuais).

O "conteúdo ideológico é inescapável” [Fai:12], porquanto a ideologia "delineia nossa visão do mundo" [Fai:27]. Se assim é, na hipótese de uma dissolução do chamado establishment, o que se instauraria no lugar não teria como ser menos ideológico. E isso não quererá dizer, em última análise, substituição de um establishment por outro? Ou... de uma elite (pensante, senhora da verdade) por outra?

Logicamente, há espaço para a persuasão, mas isso também comprova o suprarreferido "amplo alcance" e talvez nos demonstre o quão estimulante é essa condição de se poder experimentar mais de um rumo discursivo.

$5^{\circ}$ ("Mal" necessário): O positivismo lógico impôs uma forma estruturada ao pensamento; neste forjamento obtinha-se, é evidente, grande simplificação, mas o ônus fora compensado pelo parâmetro generalizante que vinha embutido.

Esse parâmetro vinha a ser justo o elemento que oportunizava medições objetivas e organização dos dados em teoria.

A abstração é necessária ao ato da compreensão, pois as análises exaustivas (se se optar pelo rito secular inventariante) não deixam perceber os sistemas mais amplos [Fai:15]... além do quê, transmitem a impressão lesiva de que o caráter "único" (que é propriedade de todo objeto!) equivale à condição de individualidade - exatamente aquela que, de fato, não autoriza legislar sobre processos. 
Não se duvide, modelos teóricos, por conceito, significam (e precisam sê-lo!) seleção de frações úteis e inteligíveis da realidade.

$6^{\circ}$ : O positivismo lógico também promoveu a tomada de consciência do argumento com o qual vinham trabalhando as disciplinas adjacentes; e dada esta "visitação" (incentivada principalmente para o caso das vizinhas "exatas"), o tradicional hábito em lidar com grandes lotes de dado tendeu a ganhar melhor apuro metodológico.

Das "conversas" se pôde esperar o aprendizado de linguagens e procedimentos que beneficiavam esses amplos estoques. (No caso, favorecendo uma seleção depurativa.)

O beneficiamento em questão - no sentido, em especial, de melhoria - contava com as perspectivas do recurso conceitual (linguagem mais sistemática, para frisar o que pudesse haver de coordenação entre os fatos) e do aporte técnico (procedimentos processadores, para testar/demonstrar possíveis nexos causais).

$7^{\circ}$ : A leitura matemático-estatística da ação humana no espaço estaria impedida apenas se o foco investigado residisse na escala do indivíduo; mas, como não - e como ainda há o fato do comportamento encontrar restrições típicas do convívio social-, tende a ser possivel inferir certa regularidade a partir de amostras amplas.

Essa "certa regularidade" é definida pelas "functional properties" [Gol:63], daí sobrevindo os "valores médios" [Fai:14]. Por consequência, apesar de tudo, há chances de se trabalhar com teoria dos conjuntos e análise de variância [Fai:18].

Modelos representam as "características mais comuns da estrutura e do funcionamento do sistema" [Chr:23]. A discrepância entre caso e modelo é, então, algo inevitável... "previsto" até, dentro de certa margem de confiabilidade. Por conseguinte, sua verificação não deve censurar o juízo abstrato; mesmo porque tal atitude recriminatória é vã, como a de, por exemplo, "ser contra" [ sic] uma dada faculdade psíquica. 
É possível "destilar" os (prováveis) padrões mecanísticos que estão "por trás" da manifestação de relações humanas e estruturas sociais. É apenas o caso de se enfrentar um duplo desafio: lidar com o maior número possível de variáveis e saber selecionar as classes de dados potencialmente significativas.

Os recenseamentos apontam, é verdade, para a relativização do "conteúdo" das paisagens, mas não há o que prove que, em havendo um significado geral para a estrutura do espaço, as cognições parciais saberiam captá-lo. Porque se é verdade que percepções individualizadas (em muitos casos, de fato, bastante divergentes qualitativamente), embaraçam o axioma materialista/mecanicista de que só haveria uma absoluta realidade exterior, não é menos verdade que a ciência está, ao menos por ora, impedida de atestar o quanto elas seriam capazes de apreendê-la.

$8^{\circ}$ : A razão abstrata é inerente ao espírito sistemático de todo pensamento científico.

Assim, mesmo o raciocínio elaborado no sentido de difamar a empresa teorética, desde que logicamente consistente, podia ser representado por linguagem simbólica. (Além do quê, seria insensato desconversar que o próprio processamento psíquico envolvido na elaboração não tem como ser essencialmente diverso do processamento de qualquer outra espécie de elaboração mental). Criticar o modo abstrato de traduzir informações é, então, recriminar uma sintaxe muito próxima àquela que rege a construção estrutural da própria crítica.

A geometrização, por exemplo, responde a uma propensão natural (biológica, talvez melhor adjetivando) do intelecto a "filtrar" ideias... no caso, classificando-as via linguagem codificada.

$9^{\circ}$ (Sob pena de modelar um desejo): O cientista naturalmente fará refletir no seu modelo explicativo o contexto provável justificante do fenômeno a explicar; portanto, se seu objeto (além dele mesmo) se encontrava imerso numa história capitalista, a teoria tinha de contemplar os mecanismos (eventualmente, ardilosos) que a engendra(va)m. 
Não se deve confundir problema ideológico com metodológico. Método é uma coisa; objetivo "por trás" de seu uso, outra. Dados e fatos são neutros; sua valorização só advém na medida em que lidos pela lente de uma teoria [Chr:21]. Ideologias correspondem a visões de mundo; estas terminam contempladas pelas teorias... que desenvolverão métodos úteis a validar as visões. Mas tratase de "chancelas" diferentes. Método e teoria só se separam para efeito didático; a separação é, em si, essencialmente um artifício [Fai:20,24].

"Mecanismos de dominância e subordinação" e "forma hierárquica" não eram criações deliberadas do modelo [Fai:17]. Nesse sentido, a crítica deveria ter sido endereçada aos valores cujos reflexos espaciais (sociais) o modelo deixava ver; e não ao modelo mesmo.

$10^{\circ}$ : A querela "privilégio da forma, negação do processo" foi um pseudoproblema, pois, dependendo da técnica e do modelo teórico empregados, o que a informação "fotográfica" transmitia era um particular contexto de inter-relações na verdade ininterruptas.

Observações discretas, "independentes", ainda que denunciando a incapacidade do tratamento matemático captar/descrever precisamente continuidades processuais, podem ser assumidas como integrantes de um sistema maior, do qual germinam (por efeito de difusão) certos atributos. Portanto, a análise estatística, mesmo que não ajudando a revelar "a cinemática do arranjo", digamos assim, pôde falar de spatial patterns - o que, por si só, já legitimava a empresa da generalização.

Teorias sistêmicas, tais como as precisamente desenvolvidas em coordenação com princípios de termodinâmica, surtiam o efeito de explanar sobre estados que, numa revelação fotográfica, podiam parecer estáveis. Estados que, a bem dizer, eram momentâneos e, por isso, expressivos de "equilíbrios dinâmicos" - sempre à mercê das contingências e oscilações (entrópicas/neguentrópicas) do entorno.

Foi, pois, capciosa a afirmação de que sustentar o modus operandi sistêmico significava endossar interpretações inerciais para o funcio- 
namento das organizações do tipo social. Porque sendo elas "sistemas abertos" (quer dizer, com múltiplos fluxos facilitando o adiamento de uma desordem insustentável), seus estados de "estabilidade" seriam, melhor descrevendo, reflexos provisórios de um ajustamento entre energia absorvida (magnitude/frequência) e capacidade circunstancial de absorção (flexibilidade/amplitude).

$11^{\circ}$ : Foi reducionista identificar a Nova Geografia essencialmente com a prática da quantificação.

O "novo" na NG, na realidade, não se limitava ao exercício do tratamento estatístico, do cálculo de índices, da verificação da aplicabilidade de fórmulas. Essas práticas, é lógico, de tão atípicas (pelo menos em alguns ramos da $\mathrm{G}$ ), ganharam notável visibilidade. E tal saliência decorria tanto da estruturação das publicações - com amplos espaços doados, por exemplo, às operações de dedução matemática -, quanto do teor dos discursos - com evidentes empregos terminológicos (instituindo um certo "dialeto") em texto e oratória. Mas no essencial esses recursos implicavam uma real transformação epistemológica. Porque o "como investigar" (ângulo metodológico) terminava reajustando o "o que investigar" (ângulo filosófico). Isto é, os expedientes reformados recondicionavam o objeto de investigação. De fato, ele não foi substituído; no entanto, tornou-se viável explorá-lo a partir de novas perspectivas (ou, no mínimo, tornou-se possível acomodar melhor - no seio de teorias robustas - as muitas perspectivas que já se sabia existirem).

Um mal-entendido recorrente foi confundir quantificação com matematização. Todo argumento racionalmente estruturado é passível de representação por lógica simbólica; entretanto, nem todo dado ou informação com que se lida nas assertivas e hipóteses serão naturalmente quantificáveis. Como sequela da confusão, os préstimos da lógica matemática restaram estigmatizados.

$12^{\circ}:$ A GTQ, no aspecto da promoção de protótipos teóricos replicáveis, conflitava com a ideologia liberal... tanto que talvez tivesse até maior desenvoltura na validação de visões de mundo austeras. 
Num certo sentido, a $G$ inclinada a trabalhar com legislação e princípios de causalidade rígidos ("rígidos" se comparados ao modelo explanatório clássico, das monografias) contrapunha-se ao paradigma capitalista da livre-iniciativa. É que uma modelagem generalizante, embora na maioria das vezes interpretada como subserviente aos propósitos da intervenção/produção capitalista, não estaria, por sua vez, menos adequada ao ideário de regimes, digamos, pouco estimuladores de comportamentos autonomistas. E se formos apostar nessa espécie de sociologia do conhecimento barata, numa situação limite, seria até mesmo possível estabelecer que o contexto mais próspero à disseminação de uma geografia signatária dos postulados da exatidão e da previsibilidade causal, teria de ser o de circunstâncias políticoeconômicas de um típico e severo estadismo... ou, quem sabe ainda mais favoravelmente, quando da vigência do socialismo real.

$13^{\circ}$ : A GTQ, se não foi tão próspera nas intenções, semeou os gestos da reflexão epistemológica e da pesquisa pragmática.

Dentre as "metas" propagandeadas, a menos atingida há de ter sido a arquitetura de teoria propriamente indígena e a (decorrente) construção de modelos pró-teste. Por outro lado, dois ganhos foram incontestáveis: um de ordem comportamental; outro, linguística. O primeiro teve, inclusive, duplo efeito. Porque o "teorético" quis dizer, em grande medida, criar o hábito da execução de uma filosofia da ciência (noutras palavras, costume de, frequentemente, pôr em vistoria a consistência do conhecimento gerado - seu teor e os expedientes para sua validação). Isso era de fato uma novidade e, desde então, todo geógrafo (independentemente do alinhamento filosófico) passaria a zelar pela qualidade de seu amparo teórico. Mas o "teorético" também quis dizer empenhar-se em subministrar informações úteis à ação prática, priorizando, então, tratamentos técnicos que as convertessem em dados operacionais. Este, o outro efeito do ganho comportamental. O ganho linguístico, por sua vez, como se presume, foi uma derivação espontânea do primeiro: sobretudo argumentos tornados sistemáticos (logo, facilitadores de um discurso feito à base de elementos mais universalistas). 
As fragilidades eventuais da GTQ podem ter apontado que ela, em verdade, representava um período preliminar de "pequenos alívios metodológicos". Algo a ainda ganhar robustez, após devida vulgarização e reinterpretações sob perspectivas teóricas vindouras. E, para tal, os dois referidos ganhos haveriam de jogar papel decisivo: o primeiro, predispondo o geógrafo às práticas interdisciplinares (por excelência, promotoras de permuta teórico-conceitual); o segundo, habilitando-o a assimilar essas conquistas metodológicas da vizinhança... tanto quanto a fazer-se entender na propagação das suas próprias.

$14^{\circ}$ : A GTQ foi um movimento cuja ambição girava em torno de metas progressistas... dentre elas, a determinação resoluta de renunciar a praxe discursiva em ciências humanas e, com isso, escapar de armadinhas metafísicas.

Muito do esforço diligente no sentido de "equiparar-se" às ciências duras explicava-se por um complexo de inferioridade (desde sempre adormecido entre os estudiosos das humanidades). E a insatisfação residia na inépcia típica dos argumentos desenvolvidos por esses cientistas, desde que, com intransigência variável, se pretendeu rescindir a tutela das ciências naturais - mais antigas e previsíveis "conselheiras". Fossem destituídos de operacionalidade (paisagens pictóricas) ou então densamente ideológicos (processos adjetivados por juízo de valor), os argumentos não rendiam qualquer efeito propositivo. Bem ao contrário, ou salvaguardavam a mera prática inventariante, ou só faziam da $\mathrm{G}$ um tablado para proselitismos políticos.

O próprio pensamento que logo viria a ser porta-voz de uma deriva crítico-radical no seio da disciplina, também ilustra o estilo de fazer ciência contra o qual a GTQ (neo)positivista quis se colocar. Dada a inaptidão da ciência social em empreender descobertas, projetar invenções e promover curas (competências atribuíveis às ciências exatas e biomédicas), nada mais lhes cabe senão: a) a mitificação de um problema; b) a glorificação de uma causa; e c) a oficialização de um dialeto. Esta última, que poderá, é claro, adquirir maneirismos 
pessoais, conforme grau de afetação do autor... a segunda, que se converte em lema mobilizador de simpatizantes e replicado em seus textos, sob leituras autorais (a "denúncia", por exemplo)... e a primeira, que põe na alça de mira um drama cuja elucidação seria uma exclusividade (o "capital", por exemplo).

Mas a empresa teorética da GTQ, por consistir exatamente no emprego de linguagem o mais objetiva possível, insistia em desviar-se de toda armadilha esotérica... como aquela que assombraria tempos precedentes e subsequentes, emboscando geógrafos num discurso em tom de ladainha. Travestida de nominalismos que lhe conferem "profundidade" e "complexidade" (o que, aliás, lhe avaliza também um ar impostor de teoria), ela o que faz é, fundamentalmente, lastimar e delatar. Mencionando aqui um causticante geógrafo francês, Henri Chamussy (habitué nos encontros do Groupe Géopoint instituição-chave na disseminação da GTQ em países francófilos), o estilo contra o qual os teoréticos quiseram se posicionar foi o de uma geografia "gasosa" (géographie gazeuse): uma geografia que sobre o que fala consegue preencher trezentas páginas, desembaraçadamente... mas que, se for minguado o espaço concedido, faz o mesmo em modestas três.

\section{Considerações finais}

Não obstante a "inclinação" que o título de nosso capítulo possa ter dado a entender, pensamos que a mais exata relevância desse rol de raciocínios se encontra bem à distância do domínio da passionalidade.

O principal pretexto para escrevê-lo foi - ao lado do escopo provocativo, mencionado na introdução - o de demonstrar (nos valendo de uma específica etapa da História do Pensamento Geográfico) que são realmente indissociáveis os elementos do contexto e da linguagem. Decerto, o exercício de constatação dessa dupla interferência de fatores deva ser possível para o exame de outras viradas epistemológicas. De todo modo, o episódio GTQ, com seus sectários e algozes, é exuberante ao demonstrá-la. 
Porque nele há, de fato, toda a convergência histórica (dirigindo os personagens a tomarem uma dada posição diante dos acontecimentos), tanto quanto a estruturação lógica (apontando sua destreza em sustentar, argumentativamente, a legitimidade das práticas). E se nessa "dupla interferência de fatores" fica patente a sempre simultânea intervenção da história da ciência (conjuntura) e da filosofia da ciência (argumento), é reconfortante notar que a epistemologia da geografia, nos lances em que vai sendo engendrada, não foge à regra.

Por conseguinte, não faz mesmo nenhum sentido defender que o distintivo das escolas de pensamento residiria num atributo de ordem estritamente teórico-vocabular... ou, então, exclusivamente histórico-sociológica. (Uma e outra, claras modalidades de reducionismo.) Bem, e a própria cizânia interpretativa, parece-nos, confirmaria a tese.

\section{Apêndices}

Dispomos nesta seção suplementar três quadros gráficos que dizem respeito, respectivamente: $1^{\circ}$ ) às "tipologias" mencionadas nos argumentos sétimo, oitavo e nono (quer dizer, aos personagens que Hurst caricaturou como sendo os agentes culpados pelo positivistic establishment das geografias clássica e teorética... mas que, cá entre nós, também se adequariam aos nossos atuais personagens do critical establishment - e, por isso mesmo, o bloco vem a ser uma releitura paródica); $2^{\circ}$ ) a um outro pequeno e ilustrativo inventário, só que especialmente de extratos nos quais se testemunham repreensões categóricas, sob a forma de trechos literais mais longos, e de autoria de "gurus" brasileiros; e $3^{\circ}$ ) a um esquema sinóptico, abreviando quais seriam as características dos sistemas filosóficos positivista e neopositivista... e de que modo, exatamente, as geografias clássica e teorética teriam veiculado (ou não) preceitos de um e outro desses sistemas. 


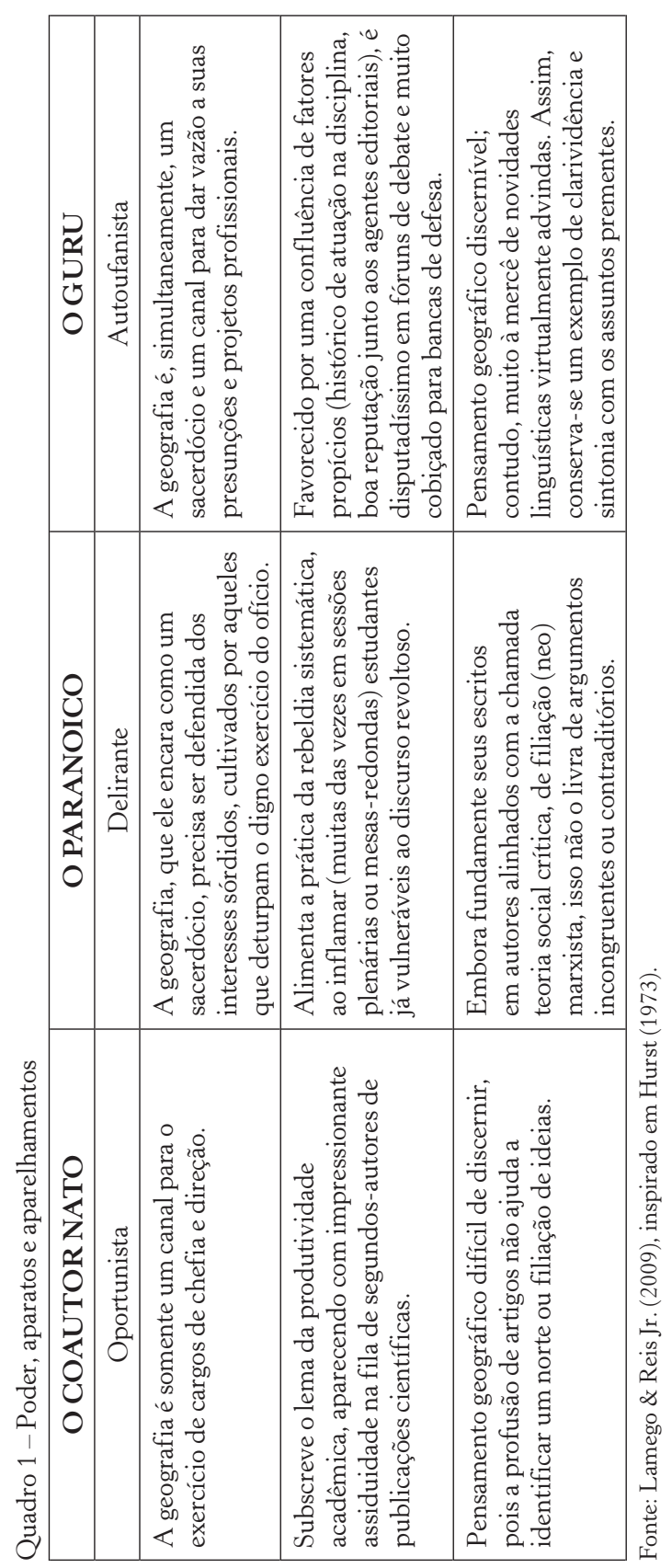




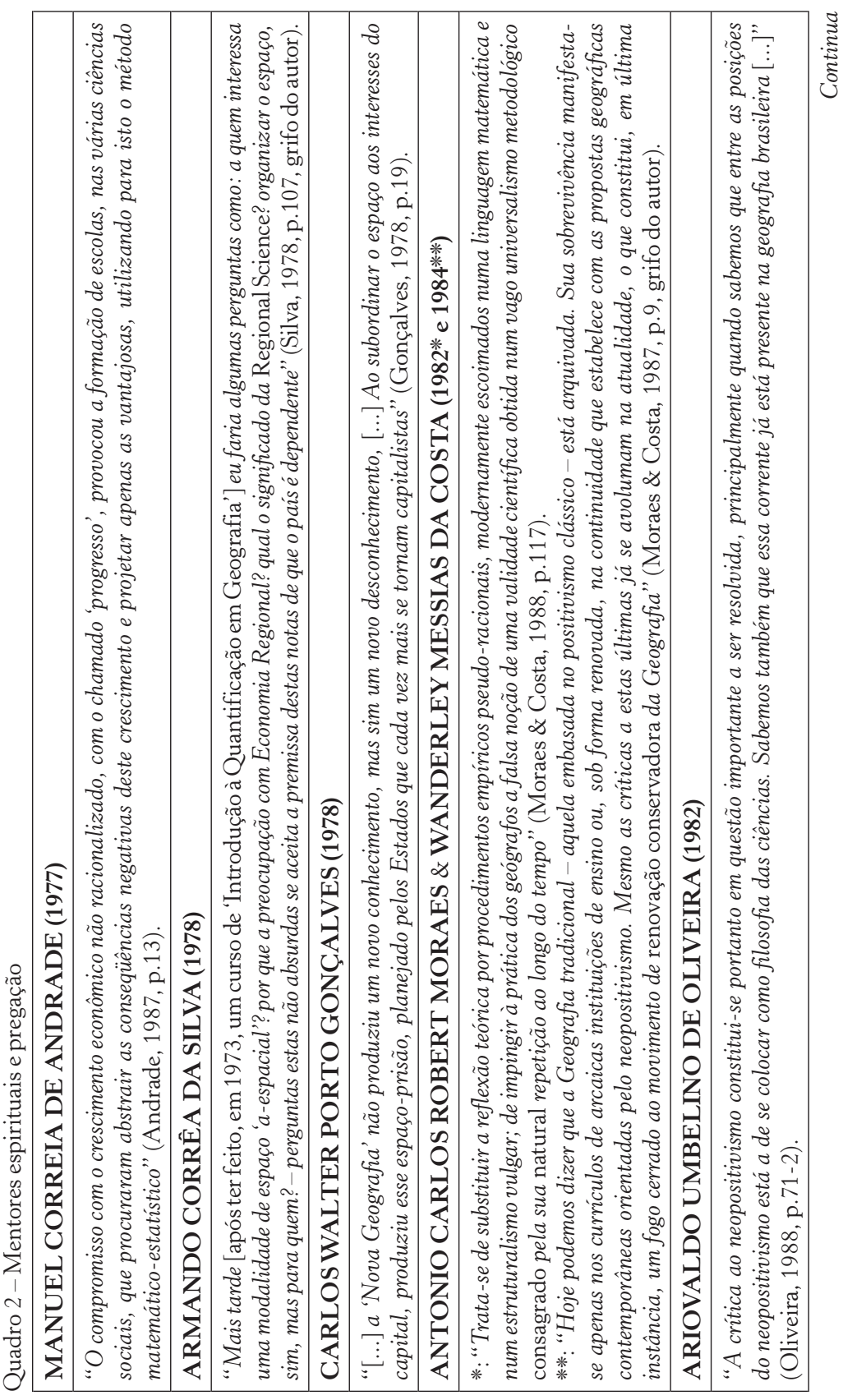




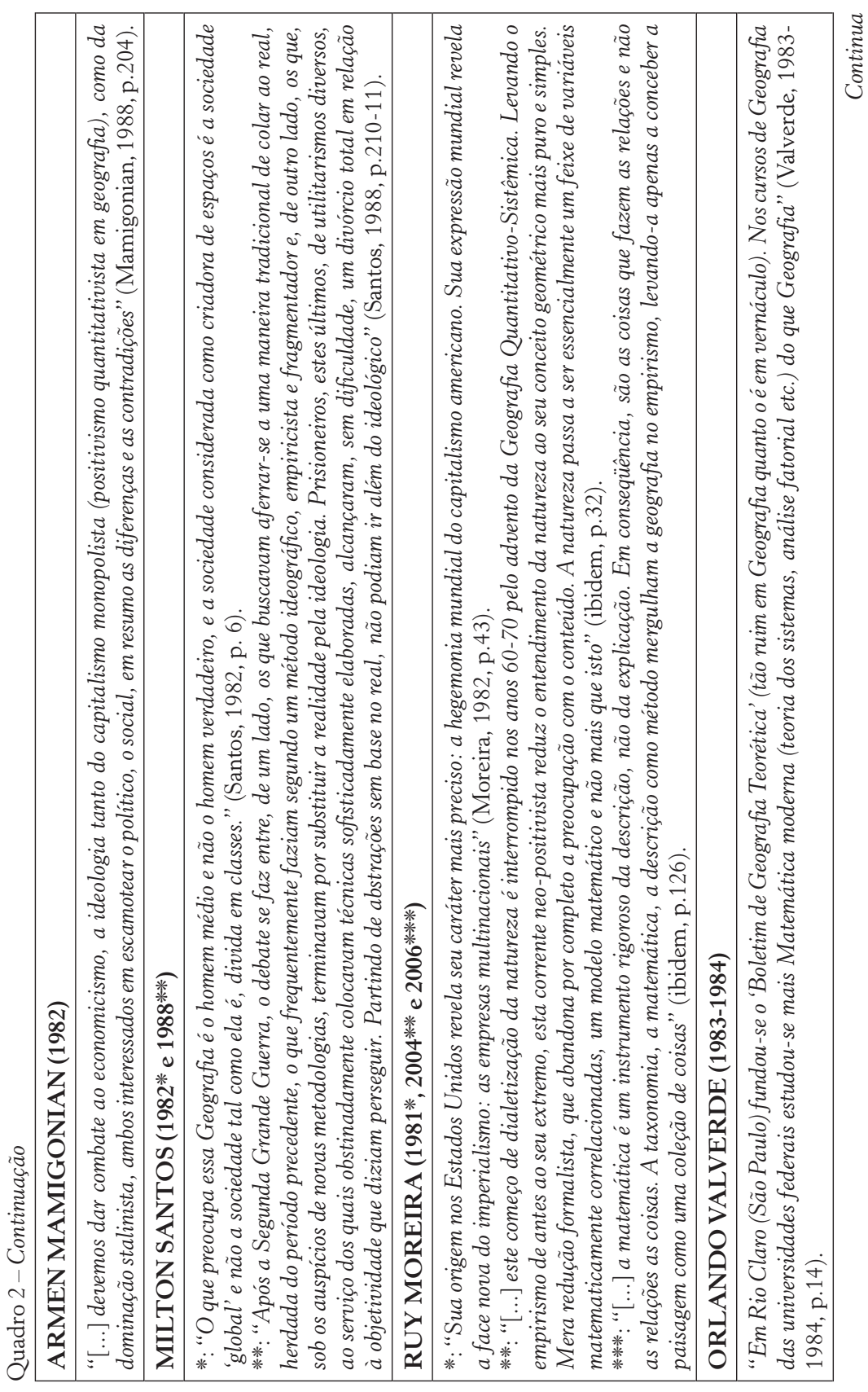



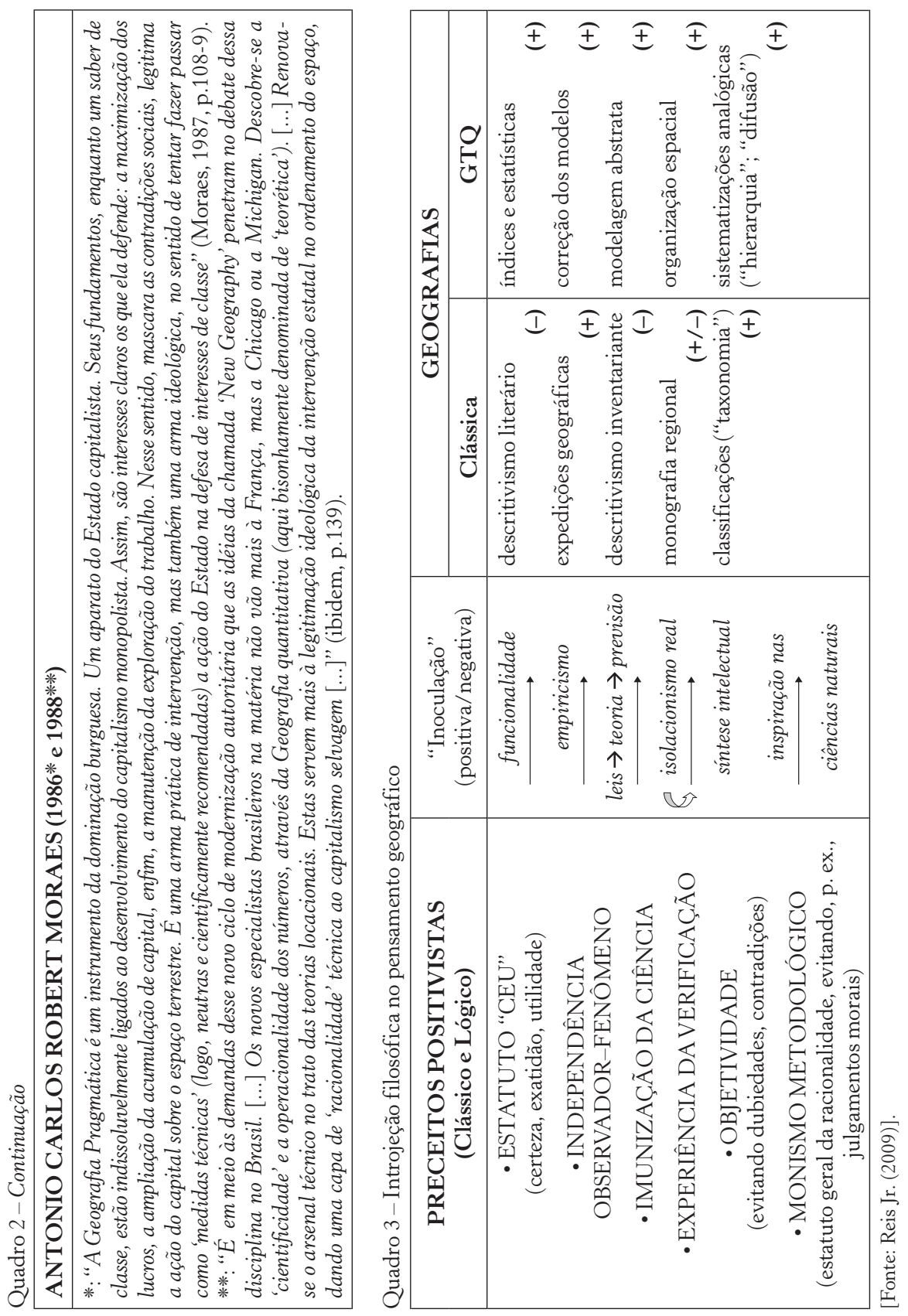


\section{Referências}

ANDRADE, M. C. de. O pensamento geográfico e a realidade brasileira. Boletim Paulista de Geografia, São Paulo, n.54, p.5-28, jun. 1977.

. Geografia, ciência da sociedade: uma introdução à análise do pensamento geográfico. São Paulo: Atlas, 1987.

BAVOUX, J.-J. La géographie: objet, méthodes, débats. 2.ed. Paris: Armand Colin, 2009.

BERRY, B. Revolutionary and counter revolutionary theory in geography - a ghetto commentary. Antipode: A Radical Journal of Geography, Worcester, v.4, n.2, p.31-3, July 1972.

BURTON. I. A revolução quantitativa e a geografia teorética. Boletim de Geografia Teorética, Rio Claro, v.7, n.13, p.63-84, 1977.

CAMARGO, J. C. G.; REIS JUNIOR, D. F. da C. A filosofia (neo)positivista e a geografia quantitativa. In: VITTE, A. C. (Org.) Contribuições à história e à epistemologia da geografia. Rio de Janeiro: Bertrand Brasil, 2007.

CHAMUSSY, H. D'amour et d'impuissance. Brouillons Dupont, n.3, p.67-81, 1978.

Le comment et le pourquoi: ou la dialectique de l'absurde et du tragique. In: COLLOQUE GÉOPOINT, 13, 2000, Avignon. Anais... Avignon: Université d'Avignon et des Pays deVaucluse, 2002. p.278-86.

CHRISTOFOLETTI, A. As características da nova geografia. Geografia, Rio Claro, v.1, n.1, p.3-33, abr. 1976.

DENEUX, J.-F. Histoire de la pensée géographique. Paris: Belin, 2006.

FAISSOL, S. A geografia na década de 80; os velhos dilemas e as novas soluções. Revista Brasileira de Geografia, Rio de Janeiro, v.49, n.3, p.737, jul./set. 1987.

FLOWERDEW, R. Some critical views of modelling in geography. In: MACMILLAN, B. (Ed.) Remodelling geography. Oxford, UK: Basil Blackwell, 1989. p.245-52.

GOLLEDGE, R. Some issues related to the search for geographical knowledge. Antipode: a Radical Journal of Geography, Worcester, v.5, n.2, p.60-6, may 1973.

GONÇALVES, C. W. P. A geografia está em crise. Viva a geografia! Boletim Paulista de Geografia, São Paulo, n.55, p.5-29, nov. 1978.

HAGGETT, P.; CHORLEY, R. J. Modelos, paradigmas e a nova geografia. In: __. (Ed.) Modelos integrados em geografia. Rio de Janeiro: Livros Técnicos e Científicos, 1974. p.1-22. 
HARVEY, D. Revolutionary and counter revolutionary theory in geography and the problem of ghetto formation. Antipode: A Radical Journal of Geography, Worcester, v.4, n.2, p.1-12, July 1972.

HURST, M. Establishment geography: or how to be irrelevant in three easy lessons. Antipode: A Radical Journal of Geography, Worcester, v.5, n.2, p.40-59, May 1973.

KITCHIN, R. Positivistic geographies and spatial science. In: AITKEN, S.; VALENTINE, G. (Ed.) Approcahes to human geography. London: Sage, 2006, p.20-9.

LAMEGO, M.; REIS JUNIOR, D. F. da C. Imposturas geográficas ou como ser um crítico naï, em três lições. In: ENCONTRO NACIONAL DA ANPEGE, 8, 2009, Curitiba. Anais... Curitiba: UFPR, 2009.

MAMIGONIAN, A. Notas sobre a geografia urbana brasileira. In: SANTOS, M. (Org.) Novos rumos da geografia brasileira. 2.ed. São Paulo: Hucitec, 1988. p.202-8.

MORAES, A. C. R. Geografia: pequena história crítica. 6.ed. São Paulo: Hucitec, 1987.

Ideologias geográficas: espaço, cultura e política no Brasil. São Paulo: Hucitec, 1988.

MORAES, A. C. R.; COSTA, W. M. da. Geografia crítica: a valorização do espaço. 2.ed. São Paulo: Hucitec, 1987.

A geografia e o processo de valorização do espaço. In: SANTOS, M. (Org.) Novos rumos da geografia brasileira. 2.ed. São Paulo: Hucitec, 1988. p.111-30.

MOREIRA, R. O que é geografia. 2.ed. São Paulo: Brasiliense, 1982. (Primeiros Passos, n.48).

O círculo e a espiral: para a crítica da geografia que se ensina - 1 . Niterói: Edições AGB Niterói, 2004.

Para onde vai a geografia?: por uma epistemologia crítica. São Paulo: Contexto, 2006.

OLIVEIRA, A. U. de. Espaço e tempo: compreensão materialista dialética. In: SANTOS, M. (Org.) Novos rumos da geografia brasileira. 2.ed. São Paulo: Hucitec, 1988. p.66-110.

REIS JUNIOR, D. F. da C. Para relembrar, cinqüenta anos depois, a empresa teorética em geografia: registros inaugurais nos AAAG e episódios ilustrativos. Geografia, v.32, n.1, p.241-52, jan./abr. 2007.

. O que não nos faz positivistas hoje? In: SEMINÁRIO DE PÓSGRADUÇÃO EM GEOGRAFIA DA UNESP, 9, 2009, Rio Claro. Anais... Rio Claro: Unesp, 2009. (Mesas-Redondas). Disponível em: $<$ http//:pensargeografia.blogspot.com $>$. 
SANTOS, M. Por uma geografia nova: da crítica da geografia a uma geografia crítica. São Paulo: Hucitec, 1978.

Para que a geografia mude sem ficar a mesma coisa. Boletim Paulista de Geografia, São Paulo, n.59, p.5-22, out. 1982.

. Novos rumos para a geografia brasileira. In: SANTOS, M. (Org.) Novos rumos da geografia brasileira. 2.ed. São Paulo: Hucitec, 1988. p.209-19.

SILVA, A. C. da. O espaço fora do lugar. São Paulo: Hucitec, 1978.

VALVERDE, O. Evolução da geografia brasileira no após-guerra (carta aberta de Orlando a Orlando). Boletim Paulista de Geografia, São Paulo, n. 60 , p. $5-20,1983 / 1984$. 



\section{7 \\ Algumas CONSIDERAÇões PARA UMA \\ REVISÃO CRÍTICA DA HISTÓRIA DO Pensamento Geográfico}

Paulo R. Teixeira de Godoy*

\section{Introdução}

A história da ciência tem cumprido um papel de suma importância na formação de concepções em torno de referenciais teóricos e ideológicos que orientam o curso do desenvolvimento científico, redefinem eixos temáticos de investigação, evolucionam conceitos e metodologias de pesquisa e, ao mesmo tempo, permitem uma compreensão mais crítica e realista de sua trajetória durante o século XX e início do XXI.

Os seus problemas temáticos têm recebido, recentemente, maior atenção, tanto pela influência que essas histórias exercem sobre a legitimidade das ciências, como pela análise e apresentação das mudanças conceituais e metodológicas pelas quais passa o pensamento científico.

A partir desse ponto de vista, as ciências sociais apresentam particular interesse, especialmente a geografia. Primeiro, porque os principais problemas teóricos e relações de conflito com outras ciências acarretam profundas mudanças em seu processo de formação

\footnotetext{
* Professor doutor assistente do Departamento de Geografia, Unesp - Rio Claro (SP).
} 
científica. Segundo, porque a uniformidade das periodizações do desenvolvimento da ciência, a partir de marcos previamente definidos pelas concepções dominantes na historiografia, apresenta-se mais como obstáculo à investigação do que uma base de orientação para a interpretação e análise de autores e obras nos referidos períodos.

A história da ciência está repleta de obras que revelam o seu desenvolvimento e seus propósitos, seja em relação à natureza, seja em relação à sociedade, e mesmo à sua própria história, mas pouco se compreende a respeito da influência dessas histórias sobre a trajetória do pensamento científico.

A crescente especialização científica no século XVIII já despertava o interesse de inúmeros autores pelas rápidas mudanças nas teorias e métodos de pesquisa. Durante o século XIX, a consciência de autoria e do caráter altamente inovador do trabalho científico fez que muitos não hesitassem em avaliar o valor de suas contribuições.

Humboldt, Ritter, Darwin e muitos outros, que deram contribuições significativas não só ao progresso da ciência, mas também ao debate epistemológico sobre ciência e não ciência, dedicaram parte importante de seus trabalhos às questões referentes aos fundamentos teóricos e metodológicos de suas investigações. Embora o interesse pelo conteúdo dos debates em torno da história da ciência e da epistemologia tenha sido significativo durante as décadas de 19701980, para a geografia não foi suficiente para a superação do caráter descritivo e memorialista da História do Pensamento Geográfico.

A história da ciência exerce também uma função essencial na reestruturação de domínios do conhecimento, fornecendo ao cientista uma imagem de si próprio, da comunidade a que pertence e do significado do seu trabalho. Por meio dela são também forjados e difundidos os mitos e as ideologias que estabelecem coesão, imprimem identidade e relevância sociopolítica à comunidade científica e aos seus representantes ilustres - os vencedores.

Se, entretanto, cada ciência tem sua própria história, por vezes em conflito ou sobreposição com outras próximas, também verifica-se que, dentro da mesma ciência, as histórias não são sempre as mesmas. A aceitação ou a possibilidade de histórias particulares como pontos 
de demarcação de domínios do conhecimento pode, por um lado, caracterizar a expressão simplista do tônus cultural do racionalismo, que visa elucidar, descrever e interpretar toda mudança no pensamento científico como sendo comparada a fatos passíveis de serem limitados por datas, obras e autores e, ao mesmo tempo, converter todos os conflitos e contradições inerentes ao progresso da ciência em sintomas necessários de descobertas científicas.

Por outro lado, submete-se ao mesmo golpe da especialização, incorrendo no reducionismo temático apresentado pelas disciplinas em seus contextos específicos, relacionados às mudanças de natureza institucional.

Há concepções que afirmam haver histórias que se destinam a comunidades científicas vizinhas ou concorrentes, com o intuito de comprovar o seu caráter científico, considerado categoricamente necessário para o reconhecimento dentro da comunidade acadêmica, e também há aquelas que são dirigidas para o interior das comunidades e que possuem objetivos mais ambiciosos relacionados aos princípios de método e normatização do conhecimento.

A existência desses dois campos de investigação na história da ciência mostra a singularidade desse gênero entre a história das produções científicas propriamente ditas, de um lado, e, de outro, aquela das instituições, das relações dos cientistas com o seu meio, das restrições ou das oportunidades sociais, econômicas, institucionais, afetando o campo cientifico em tal ou qual época.

A divisão que se impõe na história da ciência não está determinada somente pelos objetivos e pelo público a que se destina. A divisão é condição para afirmação de sua imagem. Se, no primeiro caso, os fatos, os autores e as obras testemunham o progresso alcançado por determinada ciência, no segundo, eles apontam tanto para o sucesso do paradigma quanto para a sua crise e superação. Nesse sentido, pode-se afirmar que as inovações que atravessam o edifício do conhecimento científico e seus paradigmas se impõem como necessidade de releitura dos fundamentos que justificam, historicamente, o paradigma em crise. A reconstrução da trajetória da ciência deixa de cumprir, nesse momento, o papel de legitimação dos princípios 
fundadores para tornar-se, voluntariamente, o discurso que orienta a crítica e ressalta as mudanças para a superação de impasses.

A história da ciência pode conduzir, então, a determinadas controvérsias e proposições científicas, de forma a dissimular o seu curso, alterar as referências interpretativas do contexto e omitir as incertezas e os paradoxos que perfazem as obras e o pensamento dos autores. A relação de poder se manifesta tanto pelos critérios de seleção e formas de apresentação dos fatos, como por sua descrição e explicação. $\mathrm{O}$ esforço de redefinição da trajetória dos fatos e ideias, em direção ao presente, caracteriza uma tomada de decisão política ante a história da ciência e, portanto, uma relação de poder com o passado. A coerência entre os propósitos da ciência e a construção de sua imagem coloca-se como algo necessário à sua unidade.

Nesse sentido, a história da ciência apresenta-se como uma celebração ao progresso da ciência, um discurso constituído pelas noções de constituição, regulação e progresso, e considera os escombros da prática-criativa científica (Stengers, 2002), produzidos e abandonados pelos gênios da tribo, como meras contingências decorrentes de situações irrelevantes. Segundo Bachelard (1996, p.47), "a história das ciências é um tecido de juízos implícitos sobre o valor dos pensamentos e das descobertas científicas".

Nota-se que a ausência de conteúdo político na história da ciência geográfica pode ser explicada, em parte, pelo predomínio quase exclusivo da descrição sobre a explicação e a crítica, tornando-a refratária de uma periodização que remete, inevitavelmente, a autores e obras, e não ao fluxo de conhecimento circunscrito ao contexto social e histórico.

Nesse sentido, investigar a produção de conhecimento não se faz mediante a redução do autor à sua obra ou às predeterminações de um período histórico específico. A historicidade da análise do pensamento científico deve atentar para a interação de diferentes elementos de natureza objetiva ou subjetiva, em uma covariação de tempos sociais que revelem a essência e o devir da existência do sujeito e do objeto. Ainda assim, a historicidade torna-se prisioneira da contingência que singulariza a natureza do conhecimento científico. 
A história da geografia como ciência moderna não está, assim, contida em si mesma e, tampouco, em seus precursores que, em certo sentido, não hesitaram em estabelecer os contornos de um saber que lhe conferisse legitimidade e autoridade ante outros saberes. Para evitar uma simples retificação do que é geografia, cabe recomeçar com outros dados que não a tornem objeto de definições, mas uma questão de história.

\section{A construção da ciência geográfica e o novo traje do presidente La Blache}

Em geral, até o século XIX, a história da geografia estava mais próxima de uma catalogação de fatos, de lugares e protagonistas de descobertas geográficas, do que propriamente de uma História do Pensamento Geográfico, constituída a partir de considerações acerca de teorias, conceitos e temas da geografia.

Durante o século XIX, o debate sobre os fundamentos teóricos da geografia iniciou-se por incursões no campo da história da disciplina, com o objetivo de "esquadrinhar" o passado para garantir os argumentos necessários à reconciliação dos conceitos geográficos.

Os estudos sobre os escritos de Estrabão, Eratóstenes, Ptolomeu, Plínio, Isodoro, passando por Varenius e Blache, foram de capital importância para os trabalhos realizados por Humboldt, Ritter, Ratzel e outros, que pensaram a organização do conhecimento geográfico (Kimble, 2005). Alguns trabalhos de Ratzel são emblemáticos na reconciliação entre os conceitos e o objeto de estudo. Na Teoria geral da difusão (1891), pode-se notar a preocupação sintomática em estabelecer as condições iniciais necessárias para realizar a passagem da descrição à explicação, do particular para o geral e da verificação à hipótese e, com efeito, demonstrar a ligação entre a evolução das formas culturais e sua difusão no tempo e no espaço (Harvey, 1974).

A reconciliação se realiza mediante a certeza que liga o conhecimento da gênese das formas com os processos de mudança de comportamento em relação ao meio e a explicação de sua difusão 
territorial no interior de um dado espaço. Nesse caso, os conceitos que resultam da descrição - relativos às formas - estão condicionados, a priori, pelo sentido que adquirem na explicação de natureza geográfica.

Nesse sentido, a reconciliação pode ser vista como um problema que se coloca em razão de duas situações com significativa correspondência histórica: a primeira, caracterizada pelo fato de ser uma ciência cuja institucionalização acadêmica ocorreu no final do século XIX, período em que a ciência e o conhecimento racional eram sinônimos e resultavam de uma postura neutra e objetiva por parte do sujeito; a segunda, pela sua natureza híbrida - o cruzamento entre as ciências naturais e ciências humanas, transformando os problemas de sua identidade científica em problemas epistemológicos. Ambas as situações apontam os "descaminhos" percorridos pela geografia, entre o cientificismo das ciências naturais e o empirismo das ciências humanas, entre a descrição e a explicação, e entre a razão e os sentidos.

As transformações que ocorreram no interior da geografia, a partir de meados do século XX, tornaram as fragilidades metodológicas e conceituais de sua formação científica mais visíveis e comprometeram, definitivamente, a unidade conseguida desde o início do século por meio da geografia regional.

As críticas vindas de todos os lados recaíam, como bem colocou Costa (2009), sobre o fato de a geografia ser uma ciência de síntese, isto é, uma ciência dos lugares; uma ciência indutiva, incapaz de realizar qualquer generalização; uma ciência híbrida, oscilando entre o físico e o humano; e uma ciência empírica, subjugada pelas determinações do concreto e da aparência e com imensas dificuldades de abstração.

Em contrapartida, as mudanças que estimularam novas leituras da história da geografia abandonaram a catalogação e as descobertas geográficas e passaram a centrar maior atenção nos precursores, em suas obras, nas formas de institucionalização e sua evolução geral no âmbito das ciências sociais.

Com o impacto da denominada revolução quantitativa, chegaram também os primeiros sinais da crítica antipositivista, que levou, ine- 
vitavelmente, a uma reflexão acerca da fundamentação teórica e suas implicações de natureza histórica e sociológica no desenvolvimento do pensamento geográfico.

De um lado, as obras de Manley (1966), Burton (1962), Bunge (1962), Chorley \& Haggett (1965), entre outras, representaram a versão conservadora da geografia, transformando seus pressupostos em instrumentos de intervenção e mantendo os princípios do positivismo, mas agora sob uma nova estética: a lógica formal. De outro, a fenomenologia de Dardel (1952), o marxismo de Harvey com a obra Justica social e a cidade (1968) e a geografia cultural de Sauer (1963) representaram, considerando as diferenças entre as abordagens, a versão de uma geografia mais crítica e humanística.

\section{A crise paradigmática: problema ou solução?}

Antes de abordar esse tópico, é preciso considerar algumas concepções que revelam a complexidade da noção de paradigma. $\mathrm{Na}$ acepção de Kuhn, o termo paradigma é empregado em sentido sociológico, mantendo uma estreita relação com uma visão de ciência na qual o acordo e o consenso de procedimentos prevalecem sobre o desacordo e o dissenso. Tal visão "leva muitos estudiosos a desqualificar as ciências humanas (pois lá impera a discórdia de métodos, a anarquia dos conceitos e o vale-tudo das teorias)" (Domingues, 2004, p.50).

Derivado do grego paradeigma, o termo significa modelo ou exemplo. No primeiro momento, o termo pode se referir a algo que pela sua exemplaridade pode ou deve ser seguido, ou significar e demonstrar algo que sirva de guia ou modelo.

Segundo Domingues (2004, p.52), a distinção entre modelo e paradigma se faz necessária para poder aproximar o paradigma da teoria e a acepção de modelo do método. Essa distinção permite caracterizar

uma dimensão teórica em cujo interior se formula o problema a ser investigado, se postula algo a respeito da realidade, se elege uma 
parte ou segmento do real como elemento e princípio explicativo uma força, um ente, um objeto; [e] uma dimensão metódica, instalada pela teoria e guiada por ela, a qual se encarregará, entre outras coisas, de contrastar a teoria em relação à realidade, servindo-se de técnicas e de procedimentos adequados.

O paradigma abriga, na verdade, sob seu manto constituído de consensos, várias teorias e princípios de realidade. O modelo, sob o signo da técnica e da regulação do objeto, contém múltiplos arquétipos de simplificação da realidade. Embora o modelo pressuponha uma teoria, ele se identifica mais com o método.

Feitas essas considerações, a compreensão sobre as noções de paradigma na geografia pode tornar mais claros os seus efeitos na reformulação de proposições teóricas e metodológicas nas relações entre sujeito-objeto.

No início dos anos 1960, as várias ideias difundidas em torno da geografia encontraram na obra de Kuhn (1972) a resposta sobre a importância das mudanças "revolucionárias" que foram sentidas em vários ramos da ciência nas décadas de 1950 e 1960.

A geografia foi uma das disciplinas mais profundamente afetadas pela ideia de "revolução". Em 1963, Ian Burton publicou um artigo sobre "A revolução quantitativa e geografia teórica", insistindo na importância da mudança e afirmando que a revolução havia triunfado na geografia. As ideias de Kuhn foram aceitas e aplicadas na geografia para justificar a crise e a necessidade de superação do paradigma e, ao mesmo tempo, relegar ao passado as deficiências teóricas que marcaram a gênese da geografia moderna. A partir daí, a construção de discursos a respeito de crises paradigmáticas se tornou habitual.

No final dos anos 1960, quando as questões epistemológicas tornaram-se realmente um problema para a geografia, as discussões e as controvérsias sobre os seus rumos estavam em pleno curso. As críticas sobre a relevância do objeto de estudo, sua definição e os meios para definir conhecimentos com o qualificativo de geográfico, faziam que a ideia de unidade científica ficasse cada vez mais distante. 
Se, de um lado, a concepção soberana de espaço relativo, sob o pressuposto de sua organização em termos de localização e distância, pôde satisfazer a necessidade de cientificidade e técnica de parte da comunidade de geógrafos; de outro, a insatisfação foi total. Nesse caso, é possível afirmar que o consenso sobrepôs-se ao dissenso e o modelo à teoria. $\mathrm{O}$ objeto passou a constituir uma representação e sua organização - o modelo - a representação da realidade. Com efeito, a hipótese transmutou-se em fenômeno e a "coerência racional [...] suplantou em força de convicção a coesão da experiência [logo], a variável tornou-se mais importante que a constante" (Bachelard, 2008, p.15).

A análise dessa problemática levou os geógrafos de diferentes filiações teóricas e metodológicas a discussões que gravitavam em torno de questões relacionadas às formas de teorização, aos abusos na utilização dos meios e das técnicas de quantificação, na relação ideológica entre sujeito e objeto, e ao problema do compromisso político das ciências sociais com os direitos e anseios da sociedade.

O conflito que se armou entre as propostas da geografia crítica e as da geografia funcionalista estava centrado, sobretudo, nas opostas visões de mundo entre os que pretendiam desenvolver uma geografia em prol do desenvolvimento capitalista e, portanto, um discurso em defesa dos interesses da classe dominante, e os que pretendiam construir uma geografia que fosse, em si mesma, uma crítica às desigualdades sociais produzidas pelo desenvolvimento contraditório do modo de produção capitalista. O projeto político que caracterizava as bases de ambas as propostas estava, portanto, em total desacordo quanto aos meios e às formas de atuação social do geógrafo.

Segundo Kuhn, cada mudança revolucionária na ciência leva à necessidade de reescrever a sua história, repensar as práticas científicas, seus instrumentos e seus objetivos. A New Geography seguiu criteriosamente essas orientações. As proposições neopostivistas defendiam os princípios do funcionalismo e da homogeneidade epistemológica entre ciências naturais e ciências humanas, mas também o monopólio sobre os critérios de validade do conhecimento geográfico. 
A disputa entre as correntes teóricas pela posse da nova geografia ou geografia nova não ficou restrita às questões metodológicas e conceituais, intensificou-se nas relações de poder no interior das instituições e das comunidades científicas.

O debate sobre a introdução da geografia quantitativa, nas décadas de 1950 e 1960, levou a uma verdadeira guerra simbólica no seio da comunidade geográfica. O que estava em jogo não eram apenas teorias e modelos, mas a constituição de regras para a obtenção do controle sobre a comunidade científica. A institucionalização da geografia revelou a importância da oposição e dos conflitos na comunidade científica do século XIX e o papel que as associações nacionais e internacionais de defesa dos interesses da comunidade dos geógrafos exerceram na definição do que é geografia e do que pode ser ou não considerado como geográfico.

O problema de rupturas e de continuidade paradigmática aparece nitidamente em uma ciência como a geografia. Uma breve comparação com o passado pode revelar profundas diferenças entre os seus objetivos. Se a sua gênese como ciência da descrição da Terra possui uma longa duração e certa capacidade de coesão entre os autores e obras, o seu desenvolvimento na modernidade transformou profundamente o seu campo de atuação.

No século XIX, a concepção de um conhecimento apoiado na descrição dos lugares, com ênfase nas relações de causalidade entre o homem e o meio, colocou a geografia sob a égide da análise regional: uma ciência empírica, descritiva e de síntese. Entre as décadas de 1950-1970, o embate entre a geografia quantitativa, a geografia cultural e a geografia crítica, em relação ao seu objeto de estudo, ainda ocupava o centro das preocupações. O reducionismo epistemológico não tardou em classificar essas abordagens em "quase-escolas": geografia pragmática (positivismo lógico), geografia crítica (materialismo histórico e dialético) e geografia da percepção (fenomenologia).

Nos últimos vinte anos, a geografia envolveu-se mais com a diversidade de suas temáticas de estudo do que propriamente com a discussão sobre seu objeto e sua unidade científica. A preocupação das análises volta-se, agora, mais para a ênfase nas abordagens es- 
paciais de suas problemáticas do que para os limites convencionais do campo específico da geografia.

Nesse sentido, desprovido da intenção de alongar ou aprofundar essa discussão, neste momento, vale ressaltar as orientações diversas que assumem as análises em torno da história da geografia na atualidade e quão controversas são as interpretações que fazem alusão às características de seus respectivos recortes temporais (os períodos), bem como a autores, suas obras e instituições a que pertencem.

\section{Considerações finais}

A abordagem histórica da ciência coloca-se, sem dúvida alguma, como condição essencial para entender a produção do conhecimento científico, mas ela não deve ser a única. A perspectiva que procura analisar a gênese, as relações internas da produção e organização do conhecimento, as disputas institucionais, as influências intelectuais de segmentos específicos da sociedade no interior da comunidade científica e as relações de poder que o historiador estabelece com o passado são fundamentais para a compreensão e a crítica do pensamento científico.

No caso da geografia, a tarefa de reconstrução histórica parte, geralmente, em direção ao passado, como que buscando as origens de um conhecimento que possa ser conciliado com as concepções de ciência do presente. Ou, sob outro aspecto, parte-se do passado em direção ao presente, com a certeza de encontrar uma sucessão de acontecimentos correlacionados no tempo e no espaço, de modo que culmine na confirmação do paradigma presente.

Em ambos os sentidos, a definição de ciência já está dada no ponto de partida, não se tratando, necessariamente, de uma análise histórica ou da historicidade do pensamento geográfico - uma ontologia do conhecimento ou uma hermenêutica do saber - mas uma confirmação do que está, a priori, definido como ciência.

Em suma, as considerações que podem ser apresentadas a partir dessas primeiras aproximações com a história da ciência, em geral, e 
da geografia, em particular, são dirigidas ao conjunto de relações sociais que envolvem a produção e o desenvolvimento do conhecimento científico. A ideia geral que se procurou discutir, por se acreditar na sua relevância como ponto de partida para uma crítica à História do Pensamento Geográfico, foi a de construção da imagem da ciência e sua singularidade em relação às demais. A busca pelo precursor, a celebração de suas descobertas e as relações de poder estabelecidas com o passado mostram-se reveladoras, de um lado, de sua função de legitimação da ciência e, de outro, das influências que a história da ciência desempenha sobre as comunidades científicas e sobre as formas gerais de difusão do conhecimento.

Os elementos para a crítica da História do Pensamento Geográfico carecem ainda de reflexões mais agudas, que permitam não apenas interrogar a história e dar cabo de suas invenções, mas criar possibilidades para interpretá-la de modo diferente. A crítica, como nos ensina Lebrun (2002), não nos traz uma outra verdade; ela nos ensina a pensar de outra maneira.

\section{Referências}

CORRÊA, R. L. Carl Sauer e a Geografia Cultural. Revista Brasileira de Geografia, Rio de Janeiro, v.51, n.1, p.113-22, 1989.

CHORLEY, R. J.; HAGGETT, P. Modelos Integrados em geografia. Trad. Arnaldo V. de Medeiros. São Paulo: Editora da USP, 1974.

DOMINGUES, I. Epistemologia das Ciências Sociais. São Paulo: Loyola, 2004. t.1: Positivismo e hermenêutica.

KIMBLE, G. H. T. A geografia na Idade Média. Trad. Márcia S. Carvalho. Londrina: Eduel, 2005.

KUHN, T. T. La structure des revolutions scientifiques. 2.ed. Paris: Flammarion, 1972.

STENGERS, I. A invenção das ciências modernas. Trad. Max Altman. São Paulo: Editora 34, 2002.

LEBRUN, G. Kant e o fim da metafísica. Trad. Carlos Alberto Ribeiro de Moura. São Paulo: Martins Fontes, 2002. 


\section{8 \\ AS POSSIBILIDADES DE APLICAÇÃO DO MÉTODO DE ANÁLISE REGRESSIVO- -PROGRESSIVO DE HENRI LEFÈBVRE NA GEOGRAFIA URBANA}

Silvia Aparecida Guarnieri Ortigoza*

\section{Introdução}

O presente estudo pauta-se pela análise de pesquisas em geografia urbana que tiveram como base analítica o método regressivoprogressivo de Henri Lefèbvre. Cabe ressaltar que o levantamento dessas contribuições teórico-metodológias teve como universo de pesquisa as teses e dissertações defendidas no Programa de PósGraduação em Geografia, da Unesp de Rio Claro (SP).

O quadro de enfoque teórico-metodológico na área de geografia urbana tem se tornado nos últimos anos bastante diversificado, isso porque a realidade urbana brasileira e mundial tem se apresentado cada vez mais complexa e a compreensão dos diversos problemas dependem de enfoques, muitas vezes, diferenciados e inovadores.

Nesse sentido, um dos caminhos teóricos que têm se apresentado para entender o urbano hoje passa pela contribuição de Henri Lefèbvre, que busca na complexidade da vida cotidiana a explicação para a sociedade urbana. Ao observar o cotidiano, Lefèbvre nos remete a uma reflexão bastante profunda da sociedade urbana, levando-nos

* Professora adjunta do Departamento de Geografia da Unesp - Rio Claro (SP). 
ao entendimento do espaço como produto e condição das relações sociais de produção.

Além disso, Lefèbvre (1973) retoma a questão da re-produção, e, de modo aprofundado, contribui para o entendimento da realidade socioespacial. Para ele, o processo da re-produção é bastante complexo, pois desloca, modifica e amplia as contradições, mascarando os reais conflitos da realidade. O processo de re-produção é, portanto, o grande fio condutor na análise da realidade sob o prisma lefebvriano. O autor apresenta como grande desafio uma perspectiva de abordagem que ultrapassa a descrição dos processos parciais, exigindo uma análise aprofundada das relações sociais de produção. Com esse percurso reflexivo desmistifica o entendimento de que a reprodução das relações capitalistas é um processo natural, ou seja, ele não analisa somente o modo de produção, mas vai além, colocando que o ponto focal da análise deve ser o entendimento da reprodução das relações de produção, pois é por meio dela que o capitalismo continua e continuará influente e dominador.

O cotidiano, nos três volumes da Critique de la vie quotidienne (Lefèbvre, 1958, v.I; 1961, v.II; 1981, v.III), foi uma categoria de análise amplamente trabalhada por Lefèbvre e entendido como elo e explicação de diversos aspectos da realidade. É, portanto, na obra desse autor, que os geógrafos têm buscado, em seus estudos, o sentido da interpretação do cotidiano urbano.

Martins (2000, p.57), ao trabalhar com essa interpretação do cotidiano, coloca que "É que no pequeno mundo de todos os dias está também o tempo e o lugar da eficácia das vontades individuais, daquilo que faz a força da sociedade civil, dos movimentos sociais".

Ter o cotidiano como categoria de análise significa se deter também no miúdo, no elementar, considerando na vida banal o momento do extraordinário, do possível. Para Lefèbvre, as respostas de mudança estão nesses momentos, que são a grande essência de seu método. A partir do cotidiano não generalizamos o domínio do mundial no lugar, pois necessariamente estaremos considerando o viver (que está no plano social) e o vivido (que está no plano pessoal) e encontrando nessas relações mútuas a identificação dos indivíduos 
com sua história, que é local. Por tudo isso, o cotidiano não pode ser um modelo universal, ele depende do lugar e de suas especificidades. "Se a vida de todo dia se tornou o refúgio dos céticos, tornou-se igualmente o ponto de referência das novas esperanças da sociedade. O novo herói da vida é o homem comum imerso no cotidiano" (Martins, 2000, p.57).

Segundo Lefèbvre (1981), o cotidiano é, de um lado, modalidade de organização empírica da vida humana e, de outro, um conjunto de representações que mascaram essa organização, sua contingência e seus riscos. Sua abordagem não é uma tarefa fácil, pois muitas vezes a realidade que a vida cotidiana nos passa é de muitos duplos: inconsistência e solidez; fragilidade e coesão; seriedade e futilidade; drama profundo e máscara de comédia sobre a vida. Lefèbvre procura nos mostrar os caminhos para a crítica da vida cotidiana, a qual ele classifica como uma metafilosofia do cotidiano, e que determinam as regras fundamentais de seu pensamento.

Para a realização da análise proposta neste texto é preciso apresentar o método lefebvriano, que prevê três momentos de investigação: o descritivo, o analítico-regressivo e o histórico-genético. Esse método foi proposto por Henry Lefèbvre como uma alternativa aos estudos de sociologia rural, mas pela sua riqueza, mostrou-se adaptável para diversas áreas das ciências sociais, e está formulado em seu livro De lo rural a lo urbano (Lefèbvre, 1978).

O primeiro momento do método - o descritivo - se dá pela observação do objeto de estudo, com diversas técnicas que possam ajudar na descrição.

José de Souza Martins (1996, p.21) organizou o livro Henri Lefêbvre e o retorno a dialética e nos alerta que nesse momento descritivo do método: "A complexidade horizontal da vida social pode e deve ser reconhecida na descrição do visível. Cabe ao pesquisador reconstituir, a partir de um olhar teoricamente informado, a diversidade das relações sociais, identificando e descrevendo o que vê".

Não se trata, portanto, da descrição pura e simples dos fatos, pois isso fatalmente nos levaria a uma análise parcial do fenômeno. Essa descrição, queé a primeira fase do método, deve se apoiar, sobretudo, 
em uma teoria crítica da vida cotidiana, nessa fase do trabalho: "o tempo de cada relação social ainda não está identificado. O pesquisador procede mais como um etnógrafo" (ibidem).

O segundo momento é o analítico-regressivo, que prevê a análise da realidade descrita, sem fechá-la totalmente, isto é, deverão ser consideradas as contradições e as possibilidades. Nessa fase do método, nos diz Martins (ibidem, p.21):

a realidade é analisada, decomposta. É quando o pesquisador deve fazer um esforço para datá-la exatamente. Cada relação social tem sua idade e sua data, cada elemento da cultura material e espiritual também tem a sua data. O que no primeiro momento parecia simultâneo e contemporâneo é descoberto agora como remanescente de época específica. De modo que no vivido se faz de fato a combinação prática de coisas, relações e concepções que de fato não são contemporâneas.

O terceiro momento previsto pelo método é o histórico-genético, fase também conhecida como regressiva-progressiva, onde reencontramos o presente já descrito, retomando as modificações que a estrutura nos apresenta. Trata-se do momento em que buscaremos a gênese das formações dessas estruturas, apontando um marco geral de transformação sem perder o processo de conjunto. Segundo Lefèbvre (1978), é imprescindível nesse método considerar a interação das estruturas, a influência das estruturas recentes sobre as estruturas antigas subordinadas ou integradas às primeiras.

Martins (ibidem, p.22), ao trabalhar com este método, esclarecenos que:

Nesse momento regressivo-progressivo é possível descobrir que as contradições sociais são históricas e não se reduzem a confrontos de interesses entre diferentes categorias sociais. Ao contrário na concepção lefebvriana de contradição, os desencontros são também desencontros de tempos e, portanto, de possibilidades. $\mathrm{Na}$ descoberta da gênese contraditória de relações e concepções 
que persistem está a descoberta de contradições não resolvidas, de alternativas não consumadas, necessidades insuficientemente atendidas, virtualidade não realizadas. Na gênese dessas contradições está de fato a gestação de virtualidades e possibilidades que ainda não se cumpriram.

É preciso, entretanto, antever que, embora as concepções da vida, das mudanças e da história sejam apoiadas em extensões de tempo, não significa que devam ser identificadas a partir da ideia de sucessões de etapas históricas, ou seja, recuperam-se, por esse método de investigação, as temporalidades desencontradas e coexistentes.

Nessa fase final do método, deve-se apresentar uma análise geral das modificações apontadas, sob a luz da teoria da reprodução das relações de produção. É preciso nesse momento retomar o marco de mudança já identificado reencontrando o presente. É também importante apontar as contradições emergentes, traçando as reflexões finais sobre o problema estudado.

Tanto na procura, como na análise do "marco" de mudança, devemos estar atentos, pois é a partir do momento histórico em que a reprodução das relações sociais de produção ganha outro sentido que a mundialidade do espaço consegue se manifestar.

Lefèbvre acredita que o presente não esclarece o real, por isso ele faz a regressão, procurando encontrar o marco da mudança. Esse percurso demonstrado pelo autor requer um esforço de reflexão que tem como pano de fundo o método dialético de investigação, pois nos faz enxergar que por trás de toda a coerência que o modo de produção capitalista tenta passar há um processo rico em contradição se desenvolvendo. "É dessa tensão que nasce a possibilidade da práxis revolucionária. Práxis que se funda no resgate e na unificação política dos resíduos - concepções e relações residuais que não foram capturadas pelo poder, que permaneceram nos subterrâneos da vida social, virtualidades bloqueadas" (Martins, 1996, p.23):

Trata-se de reconhecer onde estão o antigo, o novo, o diferente, pois é a relação dialética desses três movimentos que mantém a 
reprodutibilidade do sistema. O novo aparece, muitas vezes, como tendência, uma novidade que contém diferentes tempos históricos, mas que ao ser investigado pode nos oferecer os elementos para uma análise que contribua para desvendar a essência da transformação da realidade, descrita no início do trabalho. (Ortigoza, 2001, p.22)

Ao fazer o levantamento das teses e dissertações defendidas no Programa de Pós-Graduação em Geografia da Unesp de Rio Claro (SP) na área de geografia urbana e que utilizaram a teoria lefebvriana aplicando o método regressivo-progressivo em suas análises, deparamos com um total de sete pesquisas desenvolvidas com o mesmo enfoque, sendo três teses (Ortigoza, 2001; Vieira, 2002; Costa, 2003) e quatro dissertações (Silva, 2003; Godoy, 2005; Carmo, 2006; Mak, 2007). Neste texto, embora o foco mais detalhado sejam as análises da teses, citaremos também os resumos de apresentação de cada uma das dissertações, para que o leitor tenha oportunidade de observar de forma mais global as possibilidades de abordagem na geografia urbana do referido método.

\section{Singularidade teórica e pluralidade temática}

As pesquisas apresentadas a seguir estabeleceram recortes empíricos diferenciados para a análise pelo uso do método lefebvriano; desse modo, vamos procurar, em cada um dos estudos, identificar os aspectos significativos que marcam as especificidades.

\section{A construção do pensamento nas teses analisadas}

\section{- Tese 1 - Ortigoza (2001) sob o título: O tempo e o espaço da} alimentação no centro da metrópole paulista

Embora na sociedade atual não exista uma temporalidade única, existe um tempo que é quantitativo, que prevalece no espaço da me- 
trópole. Este tempo impõe um ritmo cada vez maior e mais distante do ritmo da vida, mas que torna-se, através do cotidiano, o ritmo da sociedade urbana. Esta sociedade urbana é então transformada em uma sociedade produtivista que se desenvolve no mesmo sentido da produção. As relações sociais de produção, ao determinarem esse tempo, acabam produzindo espaços que nos mostram o sentido da reprodução. (Ortigoza, 2001, p.153 e 154)

Ortigoza (2001) analisou de forma mais específica o setor de alimentação no centro de São Paulo, procurando identificar as diversas relações sociais que caracterizam as atitudes de consumo no centro da metrópole, e que acabam permitindo o desenvolvimento de algumas formas comerciais.

Portanto, o valor do espaço será entendido pela própria espacialidade contida e articulada no processo capitalista de produção, onde o próprio espaço torna-se objeto de troca. O espaço, nesse caso, passa a ser o veículo que define a troca, e o seu valor passa a ser atribuído segundo a lógica da circulação. A apropriação do espaço ganha importância nesse processo, pois é uma condição prévia e necessária à valorização. É por isso que podemos dizer que a valorização do espaço se dá de diversas formas no decorrer da história, dependendo, sobretudo, dos avanços das forças produtivas e das novas relações sociais que delas emergem. (ibidem, p.2)

A presente pesquisa teve, como universo espacial empírico, o centro da metrópole de São Paulo. Ortigoza (2001) reconhece como ponto de partida a densa e complexa rede de atividades com diversas contradições do espaço metropolitano e adverte que, nesse espaço, os problemas sociais e econômicos tornam-se ainda mais contraditórios e ao mesmo tempo mais difíceis de serem compreendidos.

Outro elemento importante discutido nessa tese é o ritmo do urbano, dado pelo processo de produção, que invade a vida social e acaba impondo aos cidadãos metropolitanos alguns comportamentos de consumo, dados pela escassez do tempo. Essa é uma das 
questões-chave dessa tese que teve como título: "O tempo e o espaço da alimentação no centro da metrópole paulista". Por meio do setor de alimentação, no centro, procurou-se entender as relações de consumo normatizadas (sob a pressão de um tempo quantitativo) que se dão no espaço contribuindo para a sua reprodução.

Nesse estudo, a análise do comércio e consumo de refeições fora do lar levou a autora a construir uma crítica da vida cotidiana dos metropolitanos. Fez isso por meio da discussão das múltiplas relações que reproduzem o espaço do centro da metrópole e que têm em seu bojo um tempo quantitativo, de uma sociedade produtivista, com um cotidiano altamente programado. O centro da metrópole foi, portanto, entendido como produto e condição das relações sociais de produção.

O comércio, como continuidade e parte integrante do processo de produção, reproduz novas formas, cada qual dando margem para que outras ainda mais padronizadas se estabeleçam. Nesse sentido, o espaço passa a ser, cada vez mais, controlado e normatizado, criando uma paisagem mundializada que contém um uso pré-determinado; tudo isso acaba estabelecendo a programação do próprio cotidiano. (ibidem, p.3)

Outro ponto importante que foi destacado pela autora é que as formas antigas vão aos poucos sendo incorporadas, pois, afinal, a racionalidade capitalista está presente e conduz o comércio e os serviços, assim como a indústria. "Em boa verdade, no mundo 'moderno', o que parece mudar permanece imutável, e o que parece estagnar-se modifica-se" (Lefèbvre, 1973, p.67).

É preciso, no entanto, compreender a materialização das formas comerciais no espaço dentro do processo de reprodução como um todo, pois ao se reproduzirem os novos processos guardam muito do velho, e o velho muitas vezes modifica-se sem muita visibilidade. Em outras palavras, é só através da análise da essência dos pro- 
cessos que notamos que a reprodução não é o novo totalmente, ela o contém mantendo algo do velho. No caso das formas comerciais, pode-se dizer que sua essência é dada pelo uso que é a mediação entre tempo e espaço. Nesse caso, não são as novas formas comerciais que transformam a vida; é o uso que, dado pela vida cotidiana, dá o novo sentido à forma, muitas vezes transformando-a. (Ortigoza, 2001, p.3 e 4)

Ortigoza resgata a ideia de que o global só se realiza no lugar (e no cotidiano), porque as relações sociais (mundializadas, novas) têm materialidade no espaço do cotidiano, que é local.

Sob o enfoque, do espaço como produto e condição das relações sociais de produção, Ortigoza vai desvendando a essência das formas comerciais de alimentação, e por meio do cotidiano dos metropolitanos procura entender o que leva as pessoas a "comerem fora de casa” - Opção? Necessidade? Manipulação? O processo de escolha pelos tipos de serviços (à la carte, por quilo, fast food) foi também amplamente investigado, relacionado os elementos preço, qualidade, e tempo de preparo.

De maneira geral, o grande desafio que essa pesquisa de Ortigoza apresentou foi o de refletir sobre as novas relações espaço-tempo na metrópole, procurando colaborar para um melhor entendimento do espaço urbano na atualidade, analisando, sobretudo o desenvolvimento de algumas formas comerciais ligadas ao setor de alimentação. Por meio da discussão do uso dessas formas, buscou-se encontrar em alguns momentos da vida cotidiana as resistências ao moderno e ao global, e o que elas nos apresentam como possibilidade.

Para dar coerência ao pensamento construído nessa tese e estabelecer a ponte entre a teoria lefebvriana e a geografia urbana, a autora estruturou seu movimento analítico tendo como base a metodologia apresentada na tese:

A nossa pesquisa contou com uma metodologia de trabalho qualitativa e que teve o apoio dos seguintes instrumentos de pes- 
quisa: revisão bibliográfica, entrevista, coleta de dados estatísticos e de informações colhidas junto aos órgãos competentes, utilização de mapas, tabelas e gráficos, notas e artigos de jornais e revistas. (Ortigoza, 2001, p.10)

Já o percurso do pensamento sobre o tema foi organizado, segundo Ortigoza (2001, p.7), da seguinte forma:

O primeiro momento - o descritivo - se dá através da observação do objeto de estudo, no nosso caso o setor de alimentação no centro da metrópole, com o apoio de técnicas de observação sistemática, entrevistas não dirigidas e dados estatísticos que possam nos ajudar na descrição. [...] Ali traçamos a problemática num nível teórico e a seguir discutimos a materialização das formas do comércio de alimentação.

O segundo momento, que marca a análise do que foi descrito no primeiro, fica demonstrado na citação que segue:

O segundo momento é o analítico-regressivo, que prevê a análise da realidade descrita, sem fechá-la totalmente, nesta fase nos propusemos a fazer uma análise comparativa das diferenças encontradas no setor de alimentação, no urbano e no cotidiano, tanto nas novas e modernas formas e relações, como nas possibilidades do rompimento do homogêneo, do normatizado. Introduzimos essa discussão no capítulo II, onde procuramos apontar as mudanças e persistências nos hábitos alimentares. (ibidem)

Ainda nesse momento é debatida a seguinte hipótese:

Apresentamos nesse momento a hipótese de que o fast food pode ser apontado como o retrato do individualismo e que através dele se dá a perda do próprio sentido (da sociabilidade) do ato de comer. As refeições a partir do fast food passam a ter signos, espaços e tempos bastante complexos. (ibidem, p.8) 
O último momento do método é, nesse estudo, apresentado do seguinte modo:

O terceiro momento previsto pelo método é o histórico-genético, reencontramos o presente já descrito, retomando as modificações que a estrutura do comércio de alimentação nos apresenta e suas relações com o espaço e o tempo da metrópole. Trata-se do momento em que buscaremos a gênese das formações dessas estruturas, apontando um marco geral de transformação sem perder o processo de conjunto. [...] Nesta fase final do método sob a luz da teoria da reprodução das relações de produção retoma-se o marco de mudança já identificado, reencontrando o presente, traçando as nossas reflexões finais. (ibidem, p.8)

Observa-se que todo o respaldo teórico tem coerência ao pensamento de Lefèbvre, pois foi no cotidiano que se procuraram as efetivas mudanças, as quais propiciaram o aparecimento das novas formas de comércio de alimentação, transformando o "comer fora de casa" em um hábito bastante frequente na vida das pessoas. A autora observa que as estruturas antigas do setor de alimentação vão sendo reproduzidas no tempo e no espaço e ganhando novo sentido.

- Tese 2 - Vieira (2002) sob o título: $O$ centro vive - O espetáculo da revalorização do centro de São Paulo: sobrevivência do capitalismo e apropriação do espaço

A cidade não é apenas a obra enquanto construção física, mas verdadeiramente carrega a humanidade do homem. Assim, é possivel ler por intermédio da cidade a própria história de nossa sociedade, inscrita na forma, cristalizada sim na obra. Deste modo, estudar São Paulo não significa apenas estudar a cidade de São Paulo, suas peculiaridades e idiossincrasias. Estudar São Paulo é buscar compreender pela análise teórica, além da empírica, o sujeito da reprodução das relações sociais de produção. (Vieira, 2002, p.379) 
Vieira (2002, p.24) inicia sua defesa do método regressivo-progressivo ao observar que:

As relações sociais, tal como as observamos no presente, têm uma aparência que, a primeira vista, pode confundir a análise do real se levarmos em conta apenas a sua aparência atual. Há a necessidade de datação das relações sociais, no sentido de que sejam identificadas as suas origens. O que observamos no presente é a coexistência de relações sociais que tem datas diferentes e que estão, assim, em descompasso e desencontro.

A partir dessas considerações, o autor vai avançando, colocando e valorizando as ideias de Lefèbvre quando reconhece a existência de uma dupla complexidade da realidade social: horizontal e vertical.

Trata-se, de uma concepção teórica e metodológica da realidade, onde se identificam, por um lado, as distinções existentes no presente, por intermédio da complexidade horizontal, e, por outro lado, se identificam as diferentes datas das relações no passado, por intermédio da análise da complexidade vertical. E, mais do que isto, desvendam-se, assim, as aparências da realidade. Sob este ponto de vista, tem-se um instrumento metodológico, o método regressivo-progressivo de que nos fala Lefèbvre. Por intermédio deste instrumento, capaz de identificar no presente as diferentes temporalidades da história, pode-se analisar o real sobrepondo-se à concepção de contemporaneidade das relações sociais. Se aparecem juntas no presente, as relações sociais, para serem entendidas de maneira correta, precisam ser datadas, precisam ter suas origens vinculadas a uma determinada data, para que se demonstre que a coexistência delas no tempo atual esconde a gênese em processos diferentes, no passado. (ibidem, p. 25 e 26)

O autor dessa tese faz uma fundamentação bastante profunda procurando mostrar a importância do método lefebvriano de análise, 
o qual permite aos geógrafos decompor as diferentes temporalidades materializadas no espaço atual.

A aplicação deste método permite observar em São Paulo uma realidade complexa e, por vezes, caótica e confusa, como de fato se apresenta. Mas é uma realidade cujas relações sociais, embora apareçam simultâneas, não o são. Por vezes, perdemos a noção de que no social e no econômico existentes hoje coexistem muitas relações de datas diferentes. Não se pode explicar o presente pela análise pura e simples do que temos hoje. É preciso voltar no passado, datar as origens, para poder mostrar as contradições e suas possibilidades de superação. O espaço produzido no século passado, que divide a rua com o espaço produzido no presente, por exemplo, são apenas aparentemente simultâneos e contemporâneos. (ibidem, p.26)

Vieira se remete a Marx ao longo de sua discussão teórica e ressalta que a proposição de Lefèbvre é "instigante e verdadeira", a partir do momento que permite reviver a essência da lógica dialética contida no próprio pensamento metodológico de Marx.

Ao dividir a tese em três grandes partes, Vieira (2002, p.27) vai dando coerência ao método:

A Primeira Parte, "A Complexidade Horizontal em São Paulo", ou sobre quando se identifica e descreve a diversidade das relações sociais no presente, comporta o Capítulo 1, "Identificando e Descrevendo o Real”. Neste momento será tratado o que adiante se fundamenta.

Lefèbvre (1978) expôs sucintamente os desdobramentos de sua concepção. A complexidade horizontal da realidade social é reconhecida num primeiro momento, a partir da descrição do visível. Neste momento, o pesquisador deverá reconstituir a diversidade das relações sociais, identificando e descrevendo o que vê. Tratase mesmo da descrição, não de uma descrição empírica, mas sim, orientada por uma informação teórica. Aqui, o tempo de cada rela- 
ção social não aparece, não é identificado. É quase um levantamento de dados descritivos da realidade, onde as relações são apresentadas sem a preocupação de relacioná-las com uma data ou origem.

O autor enriquece a discussão quando coloca que: "A bem da verdade, este momento do método resgata uma categoria bastante cara aos geógrafos, tal seja, a paisagem". E prossegue ressaltando que "os elementos da paisagem guardam em si a aparência da realidade. São mais do que isto é verdade, mas em um primeiro momento é o que mostram: a aparência" (ibidem).

Nesse momento descritivo, Vieira (2002) trata a realidade de São Paulo focando a metrópole em sua dinâmica atual. Afinal, é isso que lhe propicia a hegemonia em um processo de gerenciamento e destaque no cenário nacional e internacional. Valoriza nessa descrição as novas tecnologias, a gestão de negócios e o papel do setor imobiliário instalados em São Paulo, e ainda destaca a consolidação da cidade mundial, conectada aos fluxos da economia globalizada. Ao descrever São Paulo, para entender o seu centro, o autor passa a considerar ela mesma como um centro e, ao discutir sua centralidade, acaba por refletir sobre as diversas transformações que ocorrem no presente.

Ao continuar apresentando como foi possível aplicar o método lefebvriano de análise no estudo da reprodução do centro da metrópole, Vieira (2002, p. 29 e 30) explica como construiu a segunda parte do texto que equivale ao segundo momento do método:

A Segunda Parte, "A Complexidade Vertical no Centro", ou sobre quando se decompõe a realidade e se descobre a gênese contraditória das relações e concepções que persistem e se vislumbra o possível, está dividida em dois capítulos, cada qual tratando de um momento metodologicamente específico. O Capítulo 2, "Decompondo o Real", trata do momento da descoberta das diferentes temporalidades do presente. Neste ponto, mergulhamos na complexidade vertical da realidade social. [...] No caso deste estudo, equivale a recompor o quadro atual do centro, a partir do retorno àqueles momentos que o definiram. [...] É preciso investigar para 
determinar a data de seu surgimento. Somente assim poderá ser possível desmascarar a aparência da paisagem, tornando-a representativa do espaço enquanto produto da sociedade.

Foi possível, nesse momento, ao autor perceber que a identidade da metrópole está fortemente marcada pela porção inicial onde se assentou o seu núcleo original. Nesse sentido, as referências à cidade estão ligadas ao centro, sua transformação é contínua, mas ele se mantém como símbolo que atrai pessoas, tecnologias e, portanto, favorece os fluxos.

Um avanço nessa tese é o fato de o autor ultrapassar o presente já apresentado e vislumbrar as possibilidades do futuro.

Finalmente, o Capítulo 3, "Construindo o Virtual", se encarregará da análise daquilo que ainda está por vir. Depois de identificar o presente, retomar sua realidade a partir da decomposição, é necessário agora ultrapassar o presente, de posse do passado e compreendendo, com base nisto, as possibilidades ainda não realizadas.

O terceiro momento do método preconizado por Lefèbvre (1978) foi chamado de histórico-genético, onde se deve fazer o estudo das modificações trazidas à estrutura em questão, já datada pelo desenvolvimento posterior e por sua subordinação a estruturas de conjunto. É a tentativa de retornar ao que foi anteriormente descrito, com a finalidade de reencontrar o presente, no entanto elucidado e compreendido, vale dizer, explicado. [...] A importância da datação dos marcos fundamentais no estabelecimento das relações sociais está justamente na possibilidade de apontar os resíduos sem destruí-los, pura e simplesmente, mas aproveitando-os para uma possibilidade de práxis revolucionária. (ibidem, p.32)

De forma sintética observamos que essa tese traz um esquema de desenvolvimento do tema que baseia suas duas primeiras partes nas complexidades horizontal e vertical e já estabelece a análise. E assim, a estrutura da tese de Vieira ficou sedimentada da seguinte forma, a primeira parte trata da "Complexidade Horizontal em São Paulo", 
composta pelo Capítulo 1; a segunda parte analisa "A Complexidade Vertical no Centro", composta pelo Capítulo 2, e a terceira parte, composta pelo Capítulo 3 "Construindo o Virtual".

Algumas importantes conclusões são traçadas nessa aprofundada pesquisa, com base na revalorização do espaço, e sob o ponto de vista imobiliário, o autor revela que:

A revalorização imobiliária está inserida dentro do processo mais amplo que trata da sobrevivência do capitalismo. Como se demonstrou até aqui, o capitalismo transforma seus elementos, faz com eles passem por uma metamorfose capaz de modificar a sua aparência conservando intacta a sua essência. É esta a lógica da revalorização imobiliária. Pela incorporação do valor subjetivo da área, assentado em seu valor histórico, agrega valor objetivo aos imóveis, alterando suas funções, travestindo suas formas, fazendo de sua aparência apenas um simulacro de sua realidade. (ibidem, p.384)

Algumas conclusões servem como alerta para a relação conflituosa entre a apropriação e a dominação do espaço central, pois acaba mascarando o real papel do centro, que seria o espaço do cidadão.

A revalorização do centro só terá sentido para a cidadania e para os habitantes da metrópole se for capaz de produzir espaços onde a apropriação seja mais importante do que a dominação. Insistir na lógica dominante é construir um espaço para ser palco de conflitos, onde as possibilidades do futuro apontarão para a transgressão, para a invenção, para a superação que, enfim, instaura a produção do espaço de reprodução da vida: a apropriação. (ibidem, p.465)

Notadamente, o método em questão contribuiu de forma contundente ao entendimento do objeto de estudo e no seu movimento na história, permitiu de fato uma decomposição das complexidades envolvidas no centro da metrópole de São Paulo, no tempo e no espaço. 
- Tese 3 - Costa (2003) sob o título: $O$ centro de Recife e suas formas comerciais: transformações $e$ persistências

Entre as realidades afloradas percebemos que a legislação urbanística municipal contribui para a pulverização de centros especializados no interior das cidades, fortalecendo a relação entre o periférico, que passa a ser central, e o central que passa a ser periférico, pelo menos para alguns tipos de ramos comerciais e de serviços. Passa a haver também uma inversão de procedimentos: inicialmente, os shopping centers imitavam as cidades, mas agora as cidades imitam os shopping centers. O centro de Recife assim entra no processo de shoppinização. (Costa, 2003, p.180 e 181)

O processo de produção e reprodução espacial do centro de Recife foi analisado por Costa (2003) no sentido de compreender a tendência de transformação de um lugar tradicional do comércio varejista, rumo à sua reprodução em um espaço à semelhança dos shopping centers. Com esse problema de pesquisa, a autora discute amplamente a multiplicação das ruas shoppings no centro, abrigando praças de alimentação e outras formas modernas, com gerenciamento em forma de parceria dos poderes público e privado.

Ao discutir as transformações e as persistências das formas comerciais do "Centro Tradicional de Recife", decorrentes do Plano de Revalorização e das intervenções urbanísticas desse espaço, a autora acabou avaliando os conflitos e contradições gerados, cujos efeitos foram identificados no cotidiano do lugar. Esses embates foram detectados por meio da análise das estratégias de apropriação do espaço.

Nesse sentido, para organizar o pensamento em torno dessa problemática, esse estudo se propôs a construir uma abordagem inovadora que teve como base o método lefebvriano de análise. Assim, escreve a autora, "seu entendimento deve se situar entre a descrição e a imaginação, entre a compreensão e a análise. Deve-se desenvolver um estudo analítico e crítico da vida cotidiana, onde se juntem os fatos aos conceitos" (ibidem, p.1). 
Costa (idem, p.1) debate amplamente o método e sua aplicação, centrando toda a discussão teórica na obra de Lefèbvre e, em uma de suas reflexões coloca que:

Nesse sentido, a especificidade dessa pesquisa está em analisar em que medida a imagem de shopping centers e a programação do lugar de consumo do centro recifense, e em particular das ruasshopping, atrai antigos consumidores para suas ruas. As estratégias criadas para sua produção, os escapes e resíduos do cotidiano das pessoas que usam esse espaço serão sistematicamente analisados.

E, de forma contínua, a autora vai apresentando sua justificativa em relação ao método utilizado:

Neste trabalho, utilizaremos a análise regressiva-progressiva que caracteriza o método de abordagem da transduction de LEFÈBVRE segundo o qual se deve partir de um grau de verdade histórica, para o nível do subjetivo, individual, desenvolvendo uma análise crítica da sociedade, através de suas representações ideológicas e dos conceitos cotidianos. A transduction constrói um objeto virtual a partir de informações, atingindo as soluções com base em seus fundamentos, ou seja, vai do real para o possível. (ibidem, p. 2)

Ao trabalhar com o sentido do cotidiano em Lefèbvre, Costa coloca-o como o nível da práxis e da sociedade global. Esse nível, justifica a autora, é aquele designado por um aspecto da realidade, mas não se reduz a uma tomada de vida dessa realidade e não se dissocia de outros conceitos (palavras, degraus e planos, suas conjunturas e quadros de referências, suas perspectivas e aspectos). Desse modo, Costa (ibidem, p.2) acaba concluindo que "os níveis não coincidem entre si, mas contribuem para exprimir uma complexidade diferencial e estrutural de um todo, de uma "totalidade"."

Procurando estabelecer uma relação entre esse aspecto teórico e seu estudo empírico, Costa (ibidem, p.3), revela que: 
Portanto, para analisar o Centro de Recife, que se reproduz de forma fragmentária e complexa, e as ruas-shopping especificamente, é importante levar em consideração os vários níveis espaciais de análise, visto que eles interagem entre si, resultante de um processo de intervenções isoladas, em áreas específicas do comércio, criando novas formas comerciais que invadem as ruas, substituindo lugares públicos por privados, e estabelecendo novos hábitos de consumo do lugar e no lugar.

Procurando detalhar os procedimentos de investigação Costa (ibidem, p. 6 e 7) discrimina as etapas da pesquisa:

a) Documentação indireta: etapa que compreendeu levantamento bibliográfico, teórico e relativo ao tema. Para tanto, a descrição contribuiu na delimitação dos níveis de análise, ou seja, das escalas espaciais que interferem, ora percebidas isoladas, ora "encaixadas", com seus efeitos de reencontros e conjunturas. Assim, nesse primeiro momento de análise, veremos no nível da história, como as realidades afloradas, emergentes, consolidam-se em um certo nível espacial; b) Documentação direta: consistiu em observações, coletas de dados e informações empíricas, através de entrevistas com os produtores do espaço. Nessa etapa pretendeu-se captar uma parte do vivido "um aspecto do drama escondido, a situação dessa cotidianidade". A técnica da entrevista será aqui utilizada procurando uma relação do entrevistador e do entrevistado, onde possam aflorar os fatos mais simples da cotidianidade.

A autora, em todo o texto da tese, procura mostrar a fundamentação teórica, os conceitos que dão embasamento à análise e a metodologia utilizada para o desenvolvimento da pesquisa. Procura, dentro da produção do pensamento geográfico, buscar o encontro com os conceitos de reprodução das relações sociais. É nas formas comerciais que se busca a possibilidade do entendimento das transformações sociais no espaço urbano. Todo esse percurso teórico-metodológico 
é acompanhado da ideia de que o comércio traduz as estratégias de sobrevivência do capitalismo.

Costa (ibidem, p.8) apresenta o método de orientação do trabalho, com as etapas de operacionalização da pesquisa e as variáveis a serem investigadas, respeitados cada momento do método.

No primeiro capítulo é apresentado o Centro Tradicional de Recife privilegiando a descrição, primeira etapa do método regressivo-progressivo, quando o pesquisador deve reconhecer a complexidade horizontal, ou seja, a diversidade das relações sociais através da reconstituição, identificando e descrevendo o que vê. Nesse momento, "o tempo de cada relação social ainda não está identificado". Há, nesse capítulo, a reconstituição dos momentos históricos que criaram as intervenções nas ruas comerciais do Centro de Recife. Busca-se nesse capítulo, entender a identidade do Centro Tradicional da cidade, criada pelo conjunto de intervenções urbanas e arquitetônicas, como também pelas relações sociais calcadas no lento tempo da metrópole. Há, nesse capítulo, um quadro cronológico com as principais políticas públicas, organizadas pelos comerciantes e executadas pelas empresas públicas de urbanização municipal.

Sobre o segundo momento do método a autora revela que:

O segundo capítulo contempla a etapa seguinte do método analítico-regressivo, quando nos aprofundamos na complexidade vertical, ou seja, quando nos aprofundamos na vida cotidiana das ruas-shopping, reconhecida como resultante de relações sociais desiguais. Nesse momento, procuramos datar as relações sociais para desvendar as aparentes contemporaneidades e simultaneidades, descobrindo as épocas específicas de cada relação social presente nessa ruas, produzidas com suas velhas formas comerciais e suas novas estratégias de sobrevivência do comércio. Elaborado a partir das entrevistas dos comerciantes e consumidores das ruasshopping, os depoimentos possibilitaram averiguar as transforma- 
ções e persistências do comércio do Centro, onde destacamos: a) a popularização do ramo de comércio de vestuário, em específico, e do comércio em geral; b) a reprodução ampliada da concentração do capital, como indicador de um amplo processo de revalorização espacial e c) a segregação social do Centro. (ibidem, p. 8 e 9)

Ainda nesse momento, a autora confrontou o discurso oficial com a prática; para tanto, foram analisadas as estratégias, os instrumentos e as repercussões à luz de documentos oficiais, técnicos e políticos que participaram de sua concretização da reforma urbana no centro de Recife.

As diversas contradições encontradas são amplamente debatidas no terceiro momento do método, quando ocorre o reencontro com o presente.

No terceiro e último capítulo, procura-se analisar as contradições não resolvidas e os conflitos latentes, ou seja, a terceira etapa do método historico-genético, possibilita o reencontro do presente, porém se elucida o percebido pelo concebido teoricamente, definindo, assim, as condições e possibilidades do vivido. A generalização da mercadoria no Centro Tradicional de Comércio cria conflitos com o comércio de rua. A programação é destinada a todos os lugares, públicos e privados, criando um centro fragmentado, onde afloram contradições. Analisaremos, nesse capítulo, dois lugares que representam o desencontro de tempos e de possibilidades: o Camelódromo da Dantas Barreto e o Pólo Imperatriz, apontando as virtualidades e as possibilidades futuras de um e de outro. (ibidem, p.9)

Ao final, a autora conseguiu vislumbrar um processo de privatização do espaço público, haja vista que as Associações de Rua, por intermédio dos comerciantes, programam o uso do lugar, proíbem o comércio de rua, liberando apenas aqueles e aquilo que lhes convêm. São vários os símbolos encontrados no desenvolvimento da tese que evidenciam esse processo de privatização: grades e policiais nas 
ruas; o papel de gestor público, administrando a segurança; os comerciantes que buscam viabilizar suas vendas por meio de produtos populares, entre outros.

Uma das conclusões essenciais dessa tese é a observação de que "Nas ruas-shopping, a mercadoria comercializada solicita os consumidores a entender que qualquer semelhança é mera coincidência. Em meio a esse conflito surge o acaso, representando o afloramento de possibilidades: novas formas de comércio de rua indicam que o camelô faz a novidade" (ibidem).

Desse modo, como é amplamente discutido no texto, fica confirmado que o Centro Tradicional de Comércio de Recife vai se constituindo cada vez mais em um espaço fragmentado e conflituoso, e desse modo, essas ideias convergem com os outros dois estudos aqui apresentados no sentido de que os centros tradicionais das cidades estão deixando de ser lugar de todos para se tornar lugar de alguns.

As três teses analisadas aplicaram todos os momentos previstos no método, não como uma "camisa de força", pelo contrário, esses momentos foram sendo construídos nos encaminhamentos da investigação e apareceram como uma forma capaz de dar movimento ao pensamento elaborado pelos pesquisadores. É preciso destacar que existe toda uma preparação teórica, desde a forma como se pensa a hipótese e todo o respaldo conceitual da tese em questão, ou seja, todo o projeto tem que estar vinculado ao método, pois é ele que dá a forma de pensar a sociedade, a realidade e o espaço, essa coerência é fundamental. Enfim, para se embasar nesse método, toda a construção teórico-metodológica deverá estar assentada na visão crítica de Lefèbvre, e foi isso que encontramos nas teses apresentadas.

\section{Aplicação do método lefebvriano de análise em dissertações na área de geografia urbana}

A seguir são citados os resumos originais das dissertações que utilizaram o método lefebvriano de análise, e embora não apareça destacado nessas partes dos textos o papel do método regressivo- 
progressivo para o desenvolvimento da pesquisa, na sua íntegra as referidas dissertações se orientaram em uma teoria e metodologia coerentes ao referido método.

- Dissertação 1 - Silva (2003) sob o título: $O$ tempo e o espaço do comércio 24 horas na metrópole paulista

Resumo: A metrópole paulista desempenha papel central no comando da economia do Brasil, configurando-se como ponto de interligação e comunicação entre o mundo e nosso país, sendo a porta de entrada, consolidação e expansão dos mais diversos tipos de investimentos de capital. No comércio varejista esse movimento se torna claro quando se analisa o papel das grandes empresas brasileiras e das multinacionais a partir da força que os supermercados, hipermercados e lojas de conveniência desempenham hoje no cotidiano das cidades. A distribuição alimentar passou por inúmeras modificações nos últimos cinquenta anos introduzindo novas formas de comércio que foram adaptando-se às novas características da sociedade brasileira. O comércio 24 horas metropolitano é um atributo novo dentro do espaço urbano brasileiro e tem propiciado a construção de novos elementos para a reprodução do espaço urbano. O comércio 24 horas é o ponto central de análise desta dissertação, que ao longo de três capítulos trata de apresentar, desenvolver, analisar e concluir como que o comércio varejista brasileiro criou novos métodos para distribuir as mercadorias no espaço urbano, sendo as lojas de funcionamento 24 horas uma das últimas novidades criadas pelo comércio na busca da ampliação do lucro. (Silva, 2003, p.16)

- Dissertação 2 - Godoy (2005) sob o título: $O$ espaço da produção solidária dos catadores de materiais recicláveis - Usos $e$ contradições

Resumo: Esta dissertação discute a reprodução das relações sociais através da atividade, essencialmente urbana, desempenhada por 
catadores de materiais recicláveis. O aprofundamento teórico e metodológico, bem como o estudo de uma realidade determinada, mostram-se neste momento através da análise do espaço geográfico a partir de um objeto de estudo - as cooperativas de catadores e seu objeto de troca: os materiais recicláveis. A reprodução da vida de milhares de pessoas depende de um mercado que incluí circuitos econômicos de uma mercadoria, que para muitos é considerada lixo, mas que para outros tantos é objeto de troca. Para tanto, é necessária a análise espacial, social e econômica do mercado de materiais recicláveis, mais precisamente de empreendimentos pautados pela economia solidária, como são as cooperativas de catadores de materiais recicláveis. Esse trabalho também discute a viabilidade e a possibilidade de emancipação destes empreendimentos. (Godoy, 2005, p.V)

- Dissertação 3 - Carmo (2006) sob o título: Dinâmicas sócioespaciais na cidade de Rio Claro (SP): as estratégias politicas, econômicas e sociais na produção do espaço

Resumo: Objetiva-se, com essa dissertação, procurar a essência da produção e da reprodução da cidade, baseada na abordagem do consumo do e no espaço, tendo como alvo de investigação as ações do poder público, dos moradores e dos donos do capital, ponderando ainda o grau de influência de cada um, e verificando como o poder público tem intermediado esses conflitos, de forma a detectar quais os interesses envolvidos nessa forma de planejar a cidade. Na análise dessa problemática, tomar-se-á como área de estudo a avenida Presidente Tancredo de Almeida Neves, na cidade de Rio Claro (SP), sendo que essa uma área foi conquistando uma significativa centralidade no decorrer dos anos. Espera-se com esse estudo contribuir para o entendimento dos processos e dinâmicas socioespaciais, recentes na cidade de Rio Claro, interior de São Paulo. (Carmo, 2006, p. 5) 
- Dissertação 4 - Mak (2007) sob o título: Agentes públicos e privados na refuncionalização de formas urbanas na cidade de Campinas - SP

Resumo: O espaço geográfico e, por consequência, o espaço urbano devem ser considerados produtos e condições das relações humanas, portanto, um sistema indissociável de objetos e ações. Dentro desta visão, temos que os elementos não devem ser estudados isoladamente, de forma fragmentada, pois isso afastaria qualquer análise da realidade. Seguindo a metodologia do estudo da forma, estrutura, função, e processo, este trabalho analisará um aspecto muito comum nas cidades nos dias atuais: as edificações abandonadas. Inicialmente definidas como brownfields, termo aqui substituído por enclaves anacrônicos, ou seja, objetos técnicos que permanecem "alheios" ao processo de modernização espacial. São edificações e instalações que tiveram seu ciclo de vida interrompido por um processo de produção social do espaço de escalas regionais ou até mesmo globais, que a tornaram obsoletas, degradas e disfuncionais, demandando uma reordenação, já que estas se mostram no espaço como fraturas temporais à espera de uma nova função ou uso. Este trabalho, realizado na cidade de Campinas, tem o objetivo de avaliar dois diferentes processos de recuperação de enclaves anacrônicos, um realizado pelo poder público e outro pela iniciativa privada, buscando alcançar o entendimento de qual destes métodos apresenta resultados mais positivos à sociedade, fazendo-se uso da ideia de preservação da memória e de usos e consumo do espaço.

(Mak, 2007)

Os resultados finais das dissertações analisadas demonstram que o método regressivo-progressivo permitiu ampliar o debate, desvendar alguns enigmas e, dessa forma, contribuiu essencialmente para encontrar os marcos de mudança e as possibilidades de transformação do problema investigado. 


\section{Considerações finais}

A geografia urbana brasileira tem se projetado de modo mais eficaz no plano nacional e mundial e, portanto, alcançado maior visibilidade nos últimos anos. Muitos desses estudos têm partido da articulação dialética entre as relações sociais de produção e a reprodução do espaço para se chegar à análise crítica do urbano. O urbano como um processo dinâmico e contraditório revela conteúdos que despertam novas formas, metodologias e abordagens de pensá-lo. Assim, na geografia urbana têm surgido nos últimos anos novos enfoques, trazendo-lhe um pensamento de caráter plural. O pensamento geográfico só tem a ganhar quando o diálogo entre o pensar e o fazer provocam novas teorias. Nesse percurso, existem as continuidades, as rupturas e, muitas vezes, conexões entre a "antiga" e a "nova" forma de pensar o objeto. O objeto é uno, a temática singular; e o método? Este se constitui no grande desafio.

Encarando o método regressivo-progressivo como um grande desafio para se pensar o urbano é que estes pesquisadores aqui citados (Ortigoza, 2001; Vieira, 2002; Costa, 2003; Silva, 2003; Godoy, 2005; Carmo, 2006; Mak, 2007) trabalharam com uma perspectiva de análise inovadora dentro da geografia. Mas, para que esse método seja aceito de forma mais ampla e consagrado, muito ainda tem que ser feito no sentido debatê-lo em outras subáreas e em novas temáticas.

O cotidiano, por sua vez, é uma categoria que tem sido muito trabalhada na geografia e, nesse sentido, o entendimento de Lefèbvre sobre ele também tem sido utilizado para enriquecer o debate. O cotidiano é onde as relações sociais de produção se estruturam na vida urbana e, portanto, é por meio dele que as mudanças no tempo e no espaço conseguem se materializar. O cotidiano como categoria de análise geográfica provoca a reflexão sobre o uso social do espaço e com isso o sentido mais amplo de sua reprodução tem sido também considerado.

As cidades apresentam uma multiplicidade de padrões culturais, diferentes formas de sociabilidade, e com isso diversos usos e apropriações do espaço; esses processos não se apresentam em sua 
totalidade nos lugares e, especialmente, não são visíveis de forma imediata pelo pesquisador; desse modo, os estudos aqui apresentados desafiaram, inovaram e aprofundaram a discussão em torno de temas que podem contribuir com o desvendamento da geografia urbana na atualidade. E ficam como exemplos de estudos que estão abertos ao debate em prol do enriquecimento teórico-metodológico.

Uma opinião que é unânime em todas as pesquisas aqui citadas é que esse método regressivo-progressivo permite desvendar no seu percurso do pensamento a origem contraditória de relações e concepções, e destacar os conflitos não resolvidos, as alternativas não consumadas, as necessidades insuficientemente atendidas, as virtualidades não realizadas. De fato, esse método aponta a realidade como rica em possibilidades, as quais podem ser criadas no seio da própria contradição. Desse modo, o referido método acaba apontando para um caminho de novas perspectivas teóricas para se desvendar e enxergar o mundo.

\section{Referências}

CARMO, J. A. do. Dinâmicas sócio-espaciais na cidade de Rio Claro (SP): as estratégias políticas, econômicas e sociais na produção do espaço. Dissertação (Mestrado) - Instituto de Geociências e Ciências Exatas, Universidade Estadual Paulista "Júlio de Mesquita Filho". Rio Claro, 2006.

COSTA, K. C. R. O centro de Recife e suas formas comerciais: transformações e persistências. Tese (Doutorado) - Instituto de Geociências e Ciências Exatas, Universidade Estadual Paulista "Júlio de Mesquita Filho". Rio Claro, 2003.

GODOY, T. M. P. de. O espaço da produção solidária dos catadores de materiais recicláveis - Usos e contradições. Dissertação (Mestrado) - Instituto de Geociências e Ciências Exatas, Universidade Estadual Paulista "Júlio de Mesquita Filho”. Rio Claro, 2005.

LEFÈBVRE, H. Critique de la vie quotidienne I: Introduction. Paris: L'Arche Éditeur Paris, 1958.

Le sens de la marche - Critique de la vie quotidienne II: Fondements d'une sociologie de la quotidienneté. Paris: L'Arche Éditeur Paris, 1961. La révoluction urbaine. Paris: Gallimard, 1970. 
O pensamento marxista e a cidade. Lisboa: Ulisseia, 1972.

. A reprodução das relações de produção. Porto: Publicações Escorpião, 1973.

De lo rural a lo urbano. Barcelona: Península, 1978.

. Le sens de la marche - Critique de la vie quotidienne III: De la modernité au modernisme (Pour une métaphilosophie du quotidien). Paris: L'Arche Éditeur Paris, 1981.

La presencia e la ausencia. México: Fondo de Cultura Economica, 1983.

A vida cotidiana no mundo moderno. São Paulo: Ática, 1991.

Éléments de rythmanalyse: Introduction à la connaissance des rythmes. Paris: Éditions Syllepse, 1992.

MAK, M. A. T. F. Agentes públicos e privados na refuncionalização de formas urbanas na cidade de Campinas - SP. Dissertação (Mestrado) - Instituto de Geociências e Ciências Exatas, Universidade Estadual Paulista "Júlio de Mesquita Filho”. Rio Claro, 2007.

MARTINS, J. S. (Org.) Henri Lefébvre e o retorno à dialética. São Paulo: Hucitec, 1996.

A sociabilidade do homem simples: cotidiano e história na modernidade anômala. São Paulo: Hucitec, 2000.

ORTIGOZA, S. A. G. O tempo e o espaço da alimentação no centro da metrópole paulista. Tese (Doutorado) - Instituto de Geociências e Ciências Exatas, Universidade Estadual Paulista “Júlio de Mesquita Filho”. Rio Claro, 2001.

SILVA, C. H. C. da. O tempo e o espaço do comércio 24 horas na metrópole paulista. Dissertação (Mestrado) - Instituto de Geociências e Ciências Exatas, Universidade Estadual Paulista “Júlio de Mesquita Filho”. Rio Claro, 2003.

VIEIRA, S. G. O centro vive - O espetáculo da revalorização do centro de São Paulo: sobrevivência do capitalismo e apropriação do espaço. Tese (Doutorado) - Instituto de Geociências e Ciências Exatas, Universidade Estadual Paulista “Júlio de Mesquita Filho”. Rio Claro, 2002. 
Parte III 



\section{9 \\ RIQUEZA E MISÉRIA DO CICLO DA BORRACHA NA AMAZÔNIA BRASILEIRA: UM OLHAR GEOGRÁFICO POR INTERMÉDIO DE EUCLIDES DA CUNHA}

Fadel David Antonio Filho*

O produto do extrativismo mais importante, para a Amazônia, sob o ponto de vista econômico, particularmente no período de 1900 a 1940, sem dúvida foi a borracha. Ao longo de décadas, o centro das atenções econômicas, especialmente do capital internacional, estava voltado para a seringueira da Amazônia, a "árvore da fortuna" que produzia o látex, o leite de seringa com que se fazia a borracha. A tradicional seringueira é a Hevea brasiliensis, a seringueira verdadeira, característica das várzeas altas da margem direita do Rio Amazonas.

Outras árvores que produzem o leite (látex) para o fabrico da borracha são: o caucho (Castilloa ulei); a seringueira de terra firme (predominante na margem esquerda do rio Amazonas), a Hevea benthamiana, cujo látex é inferior; a seringueira espontânea das várzeas do baixo e médio Amazonas, a Hevea spruceana, também chamada de seringueira branca (de látex menos abundante); e a balata verdadeira (Mimusops bidentata), encontrada nos altos cursos dos afluentes da margem esquerda do Amazonas. Os índios que conheciam a borracha chamavam-na de "Hevé" ou "Cautchuc".

É possível que as primeiras notícias, mesmo imprecisas, sobre esse maravilhoso produto tenham chegado à Europa ainda com

* Professor do departamento de Geografia da Unesp, campus de Rio Claro (SP). 
Cristóvão Colombo a partir de sua segunda viagem ao Novo Mundo (1493-1495), quando aportou na ilha de Hispaniola (atual Haiti). De acordo com Tocantins (1982, p.91), há também referências de autores europeus, como Anghiera (1525), Sahagum (1529), Oviedo (1536) e Torquemada (1615) sobre o uso de "bolas" de borracha pelos nativos do Novo Mundo.

As informações mais detalhadas, entregues à Academia de Ciências de Paris, foram dadas pelo cientista francês Charles Marie de La Condamine, geodésio encarregado da missão de medir o arco meridiano terrestre e que esteve na América do Sul, passando por Equador, Peru e Amazônia brasileira, entre 1735-1743. O cientista francês relatou o uso da borracha pelos índios do Rio Napo e do Amazonas, incluindo o uso pelos portugueses, particularmente de seringas, bombas de borracha que dispensavam o êmbolo.

Apesar de toda a vigilância dos portugueses em não permitirem a saída do produto da seringueira nas mãos de estrangeiros, pequenas amostras chegaram à Europa, de uma forma ou de outra. Exportações clandestinas de borracha datam de 1800 , e desde 1770 algumas propriedades do produto tinham sido descobertas.

Somente em 1808, no entanto, com a abertura ao comércio internacional, a borracha amazônica alcançou seu lugar no comércio e indústria mundiais. O escocês Mackintosh (1823) aperfeiçoou as descobertas dos franceses e montou a primeira fábrica de impermeáveis de borracha. Em 1839, Goodyear desenvolveu o processo de vulcanização e, em 1888, John Boyd Dunlop descobriu o pneumático. Tais descobertas e inventos tiveram imediatas consequências no mercado da borracha, alcançando desde 1853-1854 ótimas cotações nas bolsas internacionais e atingindo, em 1855, o maior patamar tanto nas exportações do produto quanto nos preços.

Apesar de ocorrerem oscilações dos preços internacionais, como a de 1856-1857, as exportações e os preços da borracha amazônica chegaram ao final do século XIX em ascensão. Em 1912, a produção gomífera da Amazônia brasileira atingiu o seu máximo "pico" produtivo, decaindo até 1932, quando exportou-se em torno de seis 
mil toneladas do produto, marcando o fim do domínio econômico da borracha na região.

Uma relativa recuperação da produção gomífera na Amazônia só voltaria a ocorrer entre 1934 e 1946, pelos esforços de guerra (Segunda Guerra Mundial, 1939-1945) e pela injeção de capital norte-americano, com o "pico" em 1944 atingindo 21.192 toneladas do produto.

\section{Riqueza e miséria do ciclo da borracha na Amazônia}

O processo de ocupação da Amazônia, desencadeado pelo estímulo da borracha, foi, sem dúvida, mais profundo em comparação com o provocado pela coleta de "drogas do sertão".

Diz Tocantins (1982, p.96) que: "A miragem do lucro espetacular dominava psicologicamente as populações, miragem que foi uma constante na história econômica da borracha".

As consequências sobre outras atividades econômicas, especialmente sobre a agricultura, foram marcantes. A queda da produção do milho, do feijão e do arroz obrigou a importação desses produtos do estrangeiro, bem como o açúcar, o aguardente e a farinha, das províncias do sul do país.

A economia amazônica, que tinha como base anterior as especiarias extraídas da floresta, desde os fins do século XVIII entrara em decadência. A desestruturação do sistema de exploração de mão de obra, implantado pelos missionários religiosos, criou uma situação de estagnação econômica na região. Alguns produtos do extrativismo, ainda assim, continuaram importantes, como o cacau. A agricultura, por sua vez, recebeu incentivos, especialmente na época pombalina, com a organização das companhias de comércio.

Com o advento da borracha, a economia regional ressentiu-se da escassez de mão de obra, mormente se levarmos em conta a dificuldade de se estruturar a produção com base na mão de obra indígena local. 
As pressões do mercado internacional sobre a produção de borracha amazônica, crescentes nas últimas décadas do século XIX, forçaram, então, a busca de soluções em curto prazo. Sobre isso, escreve Furtado (1970, p.130-1) que:

A evolução da economia mundial da borracha desdobrou-se assim em duas etapas: durante a primeira encontrou-se uma solução de emergência para o problema da oferta do produto extrativo; a segunda se caracteriza pela produção organizada em bases racionais, permitindo que a oferta adquira a elasticidade requerida pela rápida expansão da procura mundial. A primeira fase da economia da borracha se desenvolve totalmente na região amazônica e está marcada pelas grandes dificuldades que apresenta o meio.

É ainda Furtado (1970, p.131-2) que, ao analisar a problemática da mão de obra, nos fins do século XIX, explica que aparentemente a imigração estrangeira, que se direcionou para a região cafeeira do Sul-Sudeste do Brasil, deixou disponível o excedente de população nordestina para a expansão da produção da borracha.

É que a Região Nordeste do Brasil, que sentira um intenso crescimento populacional na primeira metade do século XIX, especialmente em razão da diversificação da economia e do desenvolvimento da cultura algodoeira, tinha no sistema de economia de subsistência uma estrutura da qual se valia a população nos períodos de menor crescimento econômico.

Com a elevação dos preços do algodão, entretanto, em razão da Guerra da Secessão Americana, nos anos 1860, uma etapa de prosperidade no Nordeste, especialmente no Ceará, teve como consequência uma paulatina desestruturação da economia de subsistência. O problema começou a ser mais sentido a partir da segunda metade do século XIX quando, por causa do crescimento vegetativo da população, surgiram os primeiros sintomas de pressão demográfica sobre a terra, e que se agravaram de forma dramática por ocasião da grande seca de 1877-1880. A dizimação de quase todo o rebanho 
nordestino e a mortalidade de cem a duzentas mil pessoas levaram a uma concentração de população nas cidades litorâneas da região, que fugindo do flagelo da seca buscava uma desesperadora saída para a sobrevivência. As políticas governamentais de socorro aos retirantes incluíam o direcionamento da emigração para outras regiões do país, em especial para a Amazônia.

Quadro 1 - Emigração nordestina

\begin{tabular}{|c|c|}
\hline Ano & $\mathbf{n}^{\mathbf{o}}$ de imigrantes nordestinos \\
\hline 1877 & 4.610 \\
\hline 1878 & 15.300 \\
\hline 1892 & 13.593 \\
\hline 1893 & 7.380 \\
\hline 1894 & 4.443 \\
\hline 1895 & 9.092 \\
\hline 1896 & 7.686 \\
\hline 1897 & 7.312 \\
\hline 1898 & 25.872 \\
\hline 1899 & 17.045 \\
\hline 1900 & 45.792 \\
\hline TOTAL & 158.125 \\
\hline
\end{tabular}

Fonte: Benchimol (1977, p.181)

O recrutamento de braços para o trabalho nos seringais da Amazônia foi precedido de ampla propaganda subsidiada pelos próprios governos dos Estados amazônicos. Benchimol (1977, p.182) lembra que a grande imigração de nordestinos para a Amazônia coincidiu, de um lado, com a grande seca de 1877 no Nordeste, e, de outro, com a alta dos preços da borracha nos mercados internacionais. Assim foi em 1877, 1898 e 1900. De acordo com Benchimol (1977, p.181-2), as estatísticas, apesar de falhas, servem para dar uma rápida ideia da emigração de nordestinos que se dirigiram à Amazônia.

Para efeito de comparação com o número de imigrantes nordestinos que foram para a Amazônia, lembremos que em 1872 realizou-se 
o primeiro recenseamento no Brasil, resultando um total de 9.930.478 habitantes no país. O censo de 1890 resultou em 14.333.915 habitantes, e o de 1900, em 17.438.434 habitantes no país.

Furtado (1970, p.131) admite que com esse influxo externo para a Amazônia, somente no último decênio do século XIX, o número total de imigrantes chegaria a duzentos mil. Esse autor toma como base de comparação os censos de 1890 e 1900. E, ainda o mesmo autor, considerando que se um idêntico influxo ocorreu no primeiro decênio do século XX, a população deslocada para a região amazônica "não seria inferior a meio milhão de pessoas".

Benchimol (1977, p.201), por sua vez, considera que na etapa que ele denomina a I Batalha da Borracha, de 1850 a 1915, cerca de 350 mil nordestinos emigraram para a Amazônia e na II Batalha da Borracha, de 1941 a 1945, os imigrantes nordestinos aproximam-se de 150 mil, significando um total de quinhentas mil pessoas, número esse coincidente com o de Furtado (1970, p.131).

Sobre isso, escreve Benchimol (1977, p.247) que:

Quantos eram, ninguém saberá jamais. Nem o número dos nomes, nem o nome dos números, pois nunca existiram estatísticas de emigração no nordeste, e nem de imigração na Amazônia. As que se encontram foram baseadas nos quadros de pessoas saídas do porto de Fortaleza e de outras cidades do nordeste, e de pessoas entradas em Belém e Manaus. Mesmo assim, as fontes são extremamente contraditórias e, deste modo, o labor censitário dos números perde a grandeza e precisão. [...]

Tanto no primeiro como no segundo ciclo imigrantista, as levas de flagelados e retirantes atropelavam-se nos acampamentos no nordeste, enchiam os porões dos navios e, nos centros de recepção e nas hospedarias de Belém e Manaus, a confusão e a balbúrdia geravam um verdadeiro pandemônio.

Quantos partiram, quantos chegaram, quantos morreram, a crônica não registrou. Contudo, o que existe pode dar uma ideia dessa massa crítica de homens, mulheres e curumins que largaram os seus lares em busca de salvação no exílio amazônico. 
A situação do imigrante nordestino, o chamado "arigó", 1 ao chegar na Amazônia, era, entretanto, desde o início, desfavorável. Além da necessária adaptação a um meio diverso do que vivera até então, já começava a trabalhar endividado, pois que, em geral, necessitava reembolsar os gastos da viagem, os instrumentos de trabalho e outras despesas que se via obrigado a fazer ao se instalar no seringal. Essas despesas, sempre atreladas às necessidades prementes de sobrevivência, como os suprimentos alimentares, os produtos de uso doméstico ou para o próprio trabalho, perpetuavam sua dívida contraída com o empregador, o patrão e dono do seringal, que monopolizava o comércio e a compra da borracha, arbitrando preços e controlando a vida de todos nos seus domínios. ${ }^{2}$

A precária situação econômica obrigava o seringueiro a uma jornada de trabalho cruel e desumana. Percorria as picadas abertas na mata, as chamadas "estradas", desde a madrugada, quando começava a "cortar", isto é, a fazer a incisão no tronco da seringueira para extrair o látex, até o final do dia, quando de volta ao seu tapiri, barraco tosco feito de materiais retirados do meio local, iniciava a "defumação" do

1 O termo "arigó", usado para designar (pejorativamente) o imigrante nordestino que aportava na Amazônia, especialmente o que se dirigia para as cidades, é uma gíria. O conteúdo semântico dessa palavra, conforme Benchimol (1977, p.36886), em extensa explanação, escreve: "se refere a uma ave de arribação que, ao jeito das avoantes do Nordeste, migra em bandos compactos, devastando onde passa". Também encerra outras conotações, como "o malandro", "o escroncha, o lunfa, aquele que vive de surrupiar os bens dos próximos". Outros significados semânticos se referem a "aves migratórias e de rapina, sem pouso certo, hoje aqui, amanhã acolá, sem jamais fixar, e apenas vivendo num lugar enquanto não o despejam".

2 Era comum os seringais possuírem "regulamentos", verdadeiras "leis e regras" de convivência estabelecidas pelos patrões, de maneira a regular as relações de trabalho no âmbito da propriedade extrativista. Os "deveres" (não se observam "direitos" nesses regulamentos) eram específicos para cada função: "Deveres dos gerentes encarregados dos depósitos"; "Deveres do guarda-livro ou encarregado da escrita"; "Deveres dos empregados de balcão"; "Deveres dos comboieiros"; "Deveres dos fiscais"; "Deveres dos empregados de campo e diaristas"; "Deveres a que está sujeito o extrator"; "Deveres da casa com o pessoal extrator" etc. (ver Benchimol, 1977, p.231-44). 
leite retirado das dezenas ou centenas de tigelinhas que tinham sido fixadas nos troncos da Hevea, para reter a seiva.

As tarefas impostas ao homem no extrativismo da borracha obrigavam-no à exclusividade do corte. Os roçados de subsistência eram raríssimos e o seringueiro, via de regra, submetia-se a um regime alimentar que mais cedo ou mais tarde o levava a um desequilíbrio orgânico. Tornou-se hábito o consumo de "enlatados"3 adquiridos dos "aviadores", que eram os intermediários entre o patrão e as casas exportadoras, representantes dos grandes grupos econômicos internacionais, nas principais praças de comércio da região. Somavam-se a esse processo, nocivo à saúde, o esforço despendido das longas caminhadas e o depauperante trabalho num meio físico se não hostil, certamente dificultoso.

Convém observar que o meio ambiente amazônico, por si, não pode ser considerado insalubre às populações que demandavam se fixar naquelas paragens. O sistema socioeconômico que estruturou a sociedade da borracha, durante decênios, criou condições para o surgimento de doenças epidêmicas e endêmicas, num meio que apresentava um frágil equilíbrio entre seus componentes físicos mais representativos, ou seja, o clima, a floresta e os rios.

A postura determinista alimentou a ideia da insalubridade natural de certas áreas da Amazônia, como nos chamados "rios doentios", onde a malária e o beribéri se alastravam sobre a população, em geral dispersa na mata ou vivendo ao longo das margens dos afluentes e subafluentes, no trabalho de extração do látex e da produção da borracha.

Estudos de medicina tropical, e em particular sobre o saneamento da Amazônia, como os realizados por Oswaldo Cruz, Carlos Chagas e Afrânio Peixoto, nas primeiras décadas desse século, indicam que o carapanã, mosquito vetor do plasmódio de Laveran, sofreu a

3 Os alimentos em conserva correspondiam aos itens mais numerosos nas notas de fornecimento das "casas aviadoras" para os seringais. Eram: sardinhas portuguesas, carne de bife, salmão, toucinho, chouriço, leite condensado, camarões em conserva, manteiga francesa, queijo holandês, bacalhau português, atum, ervilha etc., a maioria importados. 
infectação a partir da presença do conquistador branco naquela região. O beribéri, por sua vez, encontrou corpos humanos debilitados pela avitaminose, provocada por uma alimentação rica em toxinas das conservas e carente de alimentos frescos e verduras, capazes de compensar a falta de vitaminas e sais minerais.

É sintomático observar que as áreas de colonização e povoamento mais intenso, onde havia o plantio de árvores frutíferas, o cultivo de hortas e o criatório de pequeno ou médio porte, correspondiam aos "rios saudáveis", onde as doenças epidêmicas ou endêmicas, comuns na região, ali não eram relevantes ou mesmo inexistiam.

A perversidade do sistema implantado pelo capitalismo internacional, por meio do extrativismo da borracha, impôs ao homem, na Amazônia, uma das mais ignóbeis formas de exploração das condições de trabalho nesse século.

A opulência e o progresso observados nas duas grandes cidades da região, Belém e Manaus, com a reurbanização e modernização dos transportes, a instalação da luz elétrica e da telefonia, a construção de palácios, teatros e outros edifícios públicos, em estilos copiados do neoclássico europeu, levavam à admiração do visitante e ao nítido contraste com a miséria e o abandono do interior amazônico.

Sobre isso, já em 1871, escrevia o presidente da Província do Pará, Abel Graça, em relatório para a Assembleia Legislativa (apud Tocantins, 1982, p.97) que:

A prosperidade da capital não significa de modo algum o progresso da província; pelo contrário, denuncia um verdadeiro contraste, e para conhecê-lo basta sair da capital, penetrar no interior e examinar as condições econômicas das povoações e da população.

A situação de penúria não se alterou mesmo após 1900. Num outro relatório, publicado em 1910, dessa vez pelo médico sanitarista Oswaldo Cruz, ao descrever as condições sanitárias do Rio Madeira, enfocou como exemplo a vila de Santo Antônio do Madeira, situada a 1.034 quilômetros da embocadura desse rio com o Amazonas. Originalmente, essa vila foi uma missão jesuítica fundada em 1737 
e, na passagem daquele ilustre médico pela localidade, registrava uma população de dois mil habitantes, mas chegando a três mil habitantes por ocasião da descida da safra da borracha, em batelões, quando então essa população flutuante se alojava precariamente em barracas, às margens do rio.

Escreveu Cruz que aquela vila não tinha esgotos, nem água canalizada, nem iluminação. Observou que o lixo e outros dejetos eram atirados diretamente às ruas, se é que se podiam chamar "ruas" as vielas esburacadas e enlameadas que cortavam a vila. As "colinas de lixo" jaziam apoiando-se às paredes das habitações e no centro da vila existiam grandes buracos que recebiam as águas das chuvas e das cheias do rio, transformando-se em pântanos, criatórios de mosquitos transmissores da malária e do impaludismo. Notou a ausência de um matadouro na vila, de modo que o gado era abatido em plena via pública, a tiros de carabina e com o agravante de serem abandonadas no local as porções não aproveitadas do animal (cabeça, vísceras, couro, cascas etc.). O terrível mau cheiro dos restos apodrecidos empesteavam o ar. Doenças, como o impaludismo, não cessavam de aumentar os óbitos; a mortalidade infantil era tamanha que quase não existiam crianças e as poucas que viviam tinham baixíssima expectativa de vida.

Esse patético quadro descrito por Cruz sobre uma vila na Amazônia não raro era repetido em dezenas e centenas de outras vilas, num reflexo pavoroso de um sistema socioeconômico que, ligado aos interesses do capital internacional e das elites burguesas da região, desdenhava dos mais simples princípios de humanidade, insensível às populações que constituíam a base de toda a estrutura de exploração da borracha.

O imigrante, que fugindo da seca do Nordeste brasileiro se dirigia à Amazônia, ia na maioria das vezes iludido pela fortuna fácil e pelo destemor, próprio do sertanejo, imaginando poder dominar a selva, o rio e o clima com a mesma destreza que domava o gado irritadiço nas vaquejadas. Ao chegar à Amazônia e ao se transformar em seringueiro era o "brabo", assim denominado o "novato", que se deslumbrava com a terra, com o trabalho e que sentia saudades 
da família que deixara no Nordeste. Pensava em amealhar um bom dinheiro para voltar logo. Em geral, ia ficando mais um pouco. Se constituía família e com o tempo se adaptava ao meio, virava "manso". Esse, via de regra, não deixava mais a Amazônia. Os poucos que davam sorte de juntar um dinheiro para buscar parentes que ficaram ou simplesmente para irem "a passeio" eram os "paroara". Desacostumados com a vida no sertão nordestino, depois de anos de trabalho duro nos seringais, e recebidos com despeito pela falsa impressão de estarem ricos, em geral eles voltavam para a Amazônia e para o seringal.

Ao descrever a mão de obra trabalhadora nos seringais, Tocantins (1982, p.103) explica que:

Nas próprias especializações funcionais, no seringal, destaca-se a simbiose: além do seringueiro que corta a árvore de seringa, do caucheiro que abate a árvore do caucho e lhe tira o leite, o balateiro que sangra a árvore da balata, existem, ainda, várias pessoas engajadas em tarefas ancilares, em associação íntima com as espécies vegetais e animais. São os mateiros, grupo de homens que penetram na selva para descobrir seringueiras. São os toqueiros, que ajudam os primeiros e abrem a "estrada" na floresta. São os comboieiros, que conduzem os burros de carga para o centro e trazem a borracha para a beira. São os homens de campo, que tratam do pequeno criatório e da limpeza do terreno ao largo do barracão. São os caçadores e mariscadores. Todos figuras integradas no sistema social do seringal.

A sociedade da borracha, na Amazônia, transformou quase totalmente o processo econômico, refletindo assim na vida das populações anteriormente engajadas em outras atividades. Afastou grandes parcelas de trabalhadores que se dedicavam à agricultura e "aristocratizou" a figura do patrão, dono do seringal, que na linguagem posterior a 1920 passou a ser denominado "seringalista".

O seringueiro aviltou-se ante a expansão, estimulada pelo grande capital do latifúndio. Sobre esse aspecto, ainda Tocantins (1982, p.104) escreve que: 
o seringueiro, embora livre fisicamente, constituíra-se num escravo moral do patrão pela dependência econômica, rígida, e às vezes, até mesmo num genuíno escravo, vítima de castigos corporais, tolhido nas liberdades que fundamentam a existência livre.

A expansão do processo monoextrator do látex da seringueira, depois de atingir o auge nas Ilhas e no Baixo-Amazonas, deslocou-se para a Amazônia Ocidental, alcançando o Acre, transformado-o no novo "Eldorado" da borracha, após 1900.

Não se pode esquecer que o extrativismo da borracha criou as bases da sociedade amazônica, ainda observadas na atualidade. $\mathrm{O}$ fortalecimento das cidades de Belém e Manaus, como polos centralizadores da vida política, social e econômica da região, foi um fato. Por meio de Belém e Manaus, o capital internacional, em conluio com as elites burguesas regionais, comandava todo o sistema extrativista da borracha na Amazônia. As grandes safras eram assim direcionadas para aqueles centros que sofreram grandes transformações urbanísticas, especialmente entre os últimos anos do século XIX e o primeiro decênio do século XX.

As chamadas "casas aviadoras", que funcionavam como verdadeiros bancos de crédito para financiar a produção da borracha, "amarravam" os donos de seringais com o sistema de empréstimo em gêneros e mercadorias, resgatável com a entrega da safra produzida no período. Essas "casas aviadoras", que chegaram a mais de 36 após 1900, estavam "presas" às firmas exportadoras, todas elas representantes das grandes empresas com sede em Nova York, Liverpool, Hamburgo etc., que monopolizavam o comércio da borracha no mundo. O controle dos preços internacionais do produto era feito a partir dos centros mundiais do capital internacional. As praças europeias e norte-americanas chegaram a ficar ligadas por meio de cabo submarino com Manaus e Belém, para onde as cotações das bolsas do mercado internacional eram prontamente transmitidas e com o total controle das firmas exportadoras, agentes do monopólio e que exerciam o poder de manipular as informações de acordo com seus interesses. 
Entre 1900 e 1940 (para ficarmos apenas no período de tempo em que enfocaremos nossos maiores interesses), o capital estrangeiro controlava na Amazônia brasileira uma enorme gama de atividades. Por exemplo, os ingleses, por intermédio da Companhia Manaus Harbour, controlavam o porto de Manaus; em Belém, controlavam o sistema de transporte coletivo, luz e gás com a Pará Electric e ainda a estrada de ferro de Bragança.

Os franceses, desde 1906, tornaram-se credores do Estado do Amazonas, por meio da Societé Marsellaise de Crédit Industrielle et Commerciale, e controlavam os impostos da borracha, os bondes e as rendas sobre a energia elétrica de Manaus por intermédio dos banqueiros parisienses (Mayer Fréres e Comp.). Os norte-americanos eram proprietários de trezentos mil hectares de terras no Amazonas e mais 1.500.000 hectares no Pará, na região do Rio Tapajós (Henry Ford). Além disso, controlavam o porto de Belém com a Companhia Port of Pará. Monopolizavam a compra da borracha, madeira e parte da produção de castanha (60\%) do Pará, assim como também eram proprietários de plantações de cana-de-açúcar e da produção da cachaça nesse Estado.

A navegação fluvial e a navegação marítima na Amazônia estavam, até 1940, nas mãos estrangeiras. Os ingleses controlavam a Amazon Steam Navigation, posteriormente Amazon River Steam Navigation Company (1911), que mais tarde foi estatizada, transformando-se em autarquia federal, em 1940, o SNAPP (Serviço de Navegação da Amazônia e Administração do Porto do Pará), atual Enasa (Empresa de Navegação da Amazônia SA).

O cosmopolitismo de Belém e Manaus podia ser medido pelos elogios de ilustres personagens que estiveram na região de passagem, fossem nacionais ou estrangeiros. A intensa ligação com a Europa trouxera os hábitos de finesse, o gosto apurado, a predileção pela moda e pelos autores franceses. As casas comerciais ostentavam nomes sugestivos como Bon Marché, Au Palais Royal, Bazar Paris, La Corbeille etc. No primeiro decênio do século XX, era comum companhias de óperas italianas se apresentarem em Belém e Manaus. Espetáculos no estilo vaudeville eram apresentados por companhias 
de danças espanholas, italianas e portuguesas, numa reedição do Moulin Rouge nos trópicos.

A vida literária e intelectual da região podia ser medida pelo número de jornais que se editavam em Manaus (seis) e Belém (seis) nessa época, após 1900. Grande era o número de escritores, jornalistas e poetas que agitavam a vida boêmia e literária nestas duas capitais.

Comum era a frequência com que as pessoas viajavam para a Europa, fossem elas abastados donos de seringais ou jovens intelectuais, filhos da burguesia, que se dirigiam especialmente à França. Como explica Tocantins (1982, p 126):

Centenas de paraenses e amazonenses, $[\ldots]$, atravessavam o Atlântico, uns para estudar, outros em busca de saúde nas estações termais, outros pelo prazer de viajar, de enriquecer a alma de sensações e conhecimentos. A Europa representava, naquele tempo, o que hoje significa o Rio de Janeiro para as populações regionais. Aliás, quase ninguém conhecia a capital do país, de onde só se irradiava uma influência nitidamente oficial, do interesse de Governo a Governo.

Essa colossal contradição oferecida pelo quadro econômico e social da Amazônia, em especial entre 1900 e 1940, apresentando as cidades de Belém e Manaus como "vitrines" do progresso e das benesses do capitalismo moderno, e a hinterlândia amazônica como a periferia explorada e miserável com relações de trabalho pré-capitalistas, reproduzia na escala regional o processo de ação do capital internacional.

A produção máxima da borracha amazônica foi atingida em 1912. A partir daquele ano a concorrência da borracha asiática começou a se fazer sentir no mercado mundial. As "rubber plantations" instaladas em Malásia, Índias Holandesas, Ceilão, Indochina, Bornéu, Burma e Índia passaram a ser cultivadas a partir da década de 70 do século XIX, quando foram contrabandeadas mudas da planta para o Jardim Botânico de Kew, em Londres, por Henry Alexander Wickham. 
Os anos seguintes a 1913 foram de sucessivos desastres. A borracha asiática, mais barata, suplantava sobejamente a borracha amazônica, mais cara. Os anos de 1929-1933 marcam o apogeu da crise com profundos reflexos na vida econômica e social da região. Os incentivos estrangeiros, retirados rapidamente da Amazônia, só voltaram à borracha no período da Segunda Guerra Mundial, dessa vez com exclusividade de capitais norte-americanos, em razão do esforço de guerra e na tentativa de contrapor-se aos grupos europeus que controlavam o mercado mundial da goma. Contudo, a euforia do extrativismo da borracha não retornaria à Amazônia. A depressão econômica, motivada pela quebra da hegemonia e do monopólio de produção do produto pela Amazônia, só não foi um completo desastre para as populações envolvidas diretamente com o extrativismo em razão dos esforços de se buscar outros produtos da floresta, como a castanha-do-pará (Bertholletia excelsa), por exemplo, que se não foi um substituto à altura da borracha, ao menos diminuiu o impacto depressivo daquela.

A surpresa inicial do impacto econômico, motivada pela concorrência e pelos preços, evidentemente manipulados pelo International Rubber Regulation Committee, deu lugar às falências das casas aviadoras e em sequência ao abandono de seringais e ao desemprego. O pessimismo e o declínio da vida social nas camadas burguesas de Belém e Manaus, no período após 1913, se estenderiam após 1940. A Amazônia havia deixado de ser o "Eldorado" do arigó e voltava ao ostracismo dos espaços periféricos abandonados pelo capital internacional, depois de esse ter usufruído ao máximo dos recursos naturais e dos recursos humanos que ali estavam para servi-lo.

\section{A visão de Euclides da Cunha sobre os seringais}

Euclides da Cunha esteve na Amazônia entre dezembro de 1904 e dezembro de 1905. Isso significa que a experiência do escritor com a região foi de pelo menos um ano, muito mais do que teve com o sertão baiano. E sua vivência na Amazônia não foi de um turista ou 
mero visitante, mas de um pesquisador e um observador que viveu o dia a dia das populações não só nas capitais, mas especialmente nas do interior, viajando pelos rios e atingindo os rincões mais distantes daquelas paragens. Escreveu muita coisa sobre a região, publicadas, em especial, em jornais de Manaus e do Rio de Janeiro, que foram mais tarde reunidos em Contrastes e Confrontos e À Margem da História. Mas existem alguns escritos dispersos, como o artigo "Entre os seringais" (Cunha, 1966, v.1, p.508-11), originalmente publicado na revista Kosmos, ano III, n.1, Rio de Janeiro, 1906.

Nesse artigo, Euclides da Cunha (1966, v.1, p.509) descreve a organização dos seringais do Purus e as deploráveis relações de trabalho a que estão submetidos os seringueiros. Descreve o processo de "implantação" de um seringal por intermédio de homens cujos trabalhos "especializados" são requisitados pelo dono do seringal. São eles: o mateiro, o piqueiro e o toqueiro, contratados para avaliar o sítio, abrir as "estradas" e "marcar" as "madeiras" (as seringueiras). Em sequência, relata a dura realidade do cotidiano do seringueiro, na sua "faina desgastante, prisioneira e sem perspectiva". Esse imigrante nordestino, explica Cunha, é um solitário que vive naqueles "desolamentos de desertos", numa sociedade onde "um dos mais funestos atributos" é "o da dispersão obrigatória" (ibidem, p.510).

Nota-se, neste trabalho, a clara intenção de denúncia do escritor, que ao entrar em contato íntimo com a região conheceu a bárbara exploração do latifúndio gomífero sobre o homem.

A visão do engenheiro foca com precisão o que ele chamou de "uma original medida agrária", a "estrada", e a unidade não métrica que corresponde à seringueira. Dessa forma, uma "estrada" é constituída por cem árvores (seringueiras), espalhadas ao acaso, ao longo de um espaçoso trecho da selva (ibidem, p.509).

E, um seringal médio, como tantos que existem na bacia do Rio Purus, chega a ter 300 "estradas", num espaço de 20 léguas quadradas, exigindo cerca de 150 homens para explorá-lo. Euclides da Cunha discorre da imperiosa necessidade do dono de um seringal em demarcá-lo, para então poder iniciar sua exploração efetiva, sem o que sua empreitada tornar-se-á inútil (ibidem, p.510). 
Para tanto, o primeiro intento é fazer o traçado do seringal, depois de erguido o barracão, sempre à beira do rio principal. O concurso de um sertanista contratado para tal empresa é fundamental. É o mateiro que "lança-se sem bússola no dédalo das galhadas, com segurança de um instinto topográfico surpreendente e raro" (ibidem, p.509).

A descrição das características fisiográficas do seringal espelha o olhar de um genuíno geógrafo, levando o leitor a percorrer, junto com o mateiro, aquelas paragens amazônicas. Atravessa os igapós (alagados) e os "firmes sobranceiros às enchentes", isto é, as terras altas nunca alcançadas pelas cheias dos rios. Acompanhamos o sertanista a traçar os "varadores" que serão percorridos pelo seringueiro imigrante e a avaliação rigorosa das "estradas" (ibidem, p.509).

Tudo isso sem a necessidade de registrar e "traduzir complicadas cadernetas”, usadas comumente pelos agrimensores e topógrafos de profissão. A vivência do mateiro lhe dá toda a segurança de escolher os locais certos, à beira dos igarapés, para erigir as barracas dos trabalhadores.

A visão do geógrafo e do engenheiro é refinada pela sensibilidade do literato, e Euclides da Cunha traz ao leitor a presença de figuras muitíssimos peculiares na sociedade da borracha, em especial na preparação de um sítio, em plena selva amazônica, rico em Hevea brasiliensis, a seringueira verdadeira das várzeas altas da margem direita do Rio Amazonas. São eles, além do mateiro, o toqueiro e o piqueiro, estes últimos, "dois auxiliares" indispensáveis do mateiro na demarcação e preparação de um seringal.

Magistralmente, Euclides descreve todo o trabalho desses caboclos amazônicos com a familiaridade de um verdadeiro amazônida. O conhecimento da flora e do modo de vida do caboclo são expressos ao descrever a feitura de um tapiri (que ele chama de "papiri", forma alternativa e mais antiga para designar os toscos e provisórios abrigos construídos na mata), cobertos pelas longas palmas da jarina (palmeira nativa da Amazônia).

Enquanto o mateiro vai assinalando as seringueiras a partir da "boca da estrada", isto é, o início do caminho demarcado na mata, é seguido pelo toqueiro e pelo piqueiro. O primeiro vai "marcando" 
os pés de seringa, o segundo vai abrindo a facão a estrada, que deve ficar "em pique", isto é, aberta para futuro uso do trabalhador que ali vai labutar, o nordestino imigrante, o brabo recém-chegado, o seringueiro.

Todo o processo de demarcação é descrito passo a passo, levando o leitor a caminhar pela selva, pela "estrada", picada feita ao longo da mata, de trajeto sinuoso e irregular, de seringueira em seringueira, sentindo a sensação de ali presenciar o dia a dia daqueles trabalhadores desafortunados.

$\mathrm{Na}$ visão determinista de Euclides da Cunha, a fatalidade dos processos econômico e social do seringal pode ser consubstanciada na configuração física do próprio seringal. Utiliza para isso a imagem figurada de um imenso polvo com seus tentáculos que a tudo envolve, delineando a sorte inapelável daqueles que tiveram a desventura de ali entrar. Sobre o assunto escreve Cunha:

É a imagem monstruosa e expressiva da sociedade torturada que moureja naquelas paragens. $\mathrm{O}$ cearense aventuroso ali chega numa desapoderada ansiedade de fortuna; e depois de uma breve aprendizagem em que passa de brabo a manso, consoante a gíria dos seringais (o que significa o passar das miragens que o estonteavam para a apatia de um vencido ante a realidade inexorável) ergue a cabana de paxiúna à ourela mal destocada de um igarapé pinturesco, ou mais para o centro numa clareira que a mata ameaçadora constringe, e longe do barracão senhoril, onde o seringueiro opulento estadeia o parasitismo farto, pressente que nunca mais se livrará da estrada que o enlaça, e que ele vai pisar durante a vida inteira, indo e vindo, a girar estonteadamente no monstruoso círculo vicioso da sua faina fatigante e estéril.

A pieuvre assombradora tem, como a sua miniatura pelágica, uma boca insaciável servida de numerosas voltas constritoras; e só larga quando, extintas todas as ilusões, esfolhadas uma a uma todas as esperanças, queda-se-lhe um dia, inerte, num daqueles tentáculos, o corpo repugnante de um esmaleitado, caindo no absoluto abandono. (ibidem, p.510) 
Assim, em contato direto com os acontecimentos, tal como ocorreu em Canudos de Antônio Conselheiro, no Alto Sertão Baiano, Euclides da Cunha muitas vezes avança sobre sua ideologia e consegue entender e explicar a realidade que descreve, despida dos preconceitos darwinistas sociais e deterministas. A nosso ver, esse artigo expressa um desses "relances", quando o autor assume uma postura relacionada à visão do socialismo utópico, consonante com a dos positivistas românticos.

Euclides da Cunha, ao escrever "Entre os seringais", já possuía grande vivência na região amazônica. O pequeno artigo, porém magistralmente rico em detalhes e em imagens, mostra a visão crítica do escritor sobre uma das mais cruéis formas de exploração do homem na sociedade moderna.

O seringal, unidade socioeconômica fundamental da sociedade da borracha, expressa uma das mais sórdidas relações entre capitaltrabalho, na exploração da miséria humana que contribuiu para a opulência de uns poucos e a penetração do capitalismo internacional numa da regiões mais periféricas de um país periférico, o Brasil.

$\mathrm{Na}$ importância dada ao homem, mas ao homem despossuído, o imigrante nordestino que fugindo da calamidade da seca é levado a viver nas brenhas mais profundas da imensa floresta higrófila da Amazônia brasileira, Euclides da Cunha avança sobre seu ideário positivista. Ele nos surpreende e mostra sua genialidade ante o seu tempo histórico.

Usando metáforas que conduzem a percepção do leitor a "ver" a paisagem ali descrita e a "sentir" a dramática situação daquela gente, Euclides da Cunha lembra que a sociedade da borracha apresenta "um dos mais funestos atributos, o da dispersão obrigatória". Ali o homem é um solitário, amarrado a uma faina dispersiva, atrelada a outras anomalias, contribui para criar uma sociedade estagnada, "sem destino, sem tradições e sem esperança" (ibidem, p.510).

E ao compararmos esse precioso escrito com outros trabalhos sobre o mesmo tema, como o de Plácido de Castro, o gaúcho aventureiro, libertador do Acre, que acusou Euclides da Cunha de plágio, torna-se difícil mesmo fazer comparações. A superioridade literária, a 
beleza da descrição de um assunto triste e árido, torna o artigo "Entre os seringais" uma pequena obra-prima que expressa a verdadeira face da chamada sociedade da borracha. Euclides aí se supera. E se foi um plágio (o que duvido), convenhamos, bendito plágio.

\section{Conclusões}

Euclides da Cunha deixou inúmeros escritos sobre a Amazônia. Muitos desses escritos foram publicados em forma de livros: Contrastes e confrontos (1907), À margem da história (1909), Peru versus Bolívia (1907), e inúmeros artigos em jornais e revistas que nos dão a dimensão do seu interesse pela região.

A experiência como correspondente de guerra, pelo jornal $O$ Estado de S. Paulo, nos sertões de Canudos, foi de pouco mais de vinte dias no teatro de operações, enquanto na Amazônia sua vivência foi de praticamente um ano.

As primeiras impressões de Euclides da Cunha sobre a Amazônia não foram animadoras. Com o passar do tempo, aquele "espaço de Milton" que "esconde-se em si mesmo", impregnou-lhe o espírito, a observação primorosa e a pena magistral. A Amazônia tornou-se-lhe íntima e a partir daí produziu uma lavra de escritos, entre artigos, cartas, relatórios, insuperáveis. Era o prelúdio de um segundo "livro vingador" (o primeiro foi Os sertões), do qual já tinha até um título: Um paraíso perdido.

Seria, sem dúvida, um livro extraordinário, se nos basearmos no que Euclides da Cunha já havia até então produzido sobre a Amazônia. Sua trágica e precoce morte impediu a concretização desse sonho. A perda maior foi nossa, foi do Brasil.

Em compensação, o legado de Euclides da Cunha sobre a Amazônia, ainda assim, é riquíssimo. Se o gênio euclidiano criou $O s$ sertões, uma obra-prima de nossas letras, e para tanto vivenciou o espaço semiárido do sertão baiano por pouco tempo, imaginemos o que seria Um paraíso perdido. 


\section{Referências}

ANTONIO FILHO, F. D. O pensamento geográfico de Euclides da Cunha: uma avaliação. Dissertação (Mestrado) - Instituto de Geociências e Ciências Exatas, Universidade Estadual Paulista "Júlio de Mesquita Filho". Rio Claro, 1990.

A visão da Amazônia Brasileira: uma avaliação do Pensamento Geográfico entre 1900-1940. Tese (Doutorado) - Instituto de Geociências e Ciências Exatas, Universidade Estadual Paulista "Júlio de Mesquita Filho". Rio Claro, 1995.

BENCHIMOL, S. Amazônia: um pouco - antes e além - depois. Manaus: Ed. Umberto Calderaro, 1977.

CUNHA, E. da. Obra completa. Rio de Janeiro: Cia. José Aguilar Editora, 1966. $2 \mathrm{v}$

FURTADO, C. Formação econômica do Brasil. São Paulo: Cia. Editora Nacional, 1970.

TOCANTINS, L. Amazônia - Natureza, homens e tempo. 2.ed. rev. e ampl. Rio de Janeiro: Civilização Brasileira, 1982. (Coleção Retratos do Brasil, v.165). 



\title{
10 \\ DisCUTINDO CATEgORIAS E CONCEITOS: UMA CONTRIBUIÇÃO GEOGRÁFICA DENTRO DAS ANÁLISES DA RELAÇÃO RURAL-URBANO
}

\author{
Adriano Corrêa Maia* \\ Darlene Aparecida de Oliveira Ferreira**
}

\section{Introdução}

O texto em tela contém dois objetivos, o primeiro consiste na busca de um entendimento sobre as categorias em que estão baseados os fundamentos teórico-metodológicos da ciência geográfica. $\mathrm{O}$ segundo é a construção de uma proposição metodológica que permita uma categorização geográfica para se pensar a relação entre o rural e o urbano a partir de uma teoria espacial.

Assim, para o desenvolvimento do argumento principal, o entendimento das categorias dentro do arcabouço teórico-metodológico da geografia e sua aplicação no entendimento geográfico da relação entre o rural e o urbano, vamos posicionar o debate sobre categorias dentro da teoria do conhecimento. Após, discutiremos como as categorias vão ser absorvidas dentro de algumas matrizes geradores do pensamento geográfico (Santos, 1978, 1985; Moreira, 2007, Suertegaray, 2001).

* Mestrando do Programa de Pós-Graduação em Geografia, Unesp - Rio Claro (SP).

** Professora doutora assistente do Departamento de Geografia, no Programa de Pós-Graduação em Geografia, Unesp - Rio Claro (SP). 
A partir desses desenvolvimentos, pretendemos nos lançar na tentativa de construção de um caminho metodológico que permita uma leitura objetiva da relação rural-urbano por meio de categorias geográficas.

\section{Categorias e a teoria do conhecimento}

Dentro do desenvolvimento que objetivamos realizar, a primeira delimitação a ser colocada é sobre o significado de conhecimento. Segundo o dicionário de filosofia Lalande (1999, p.172), conhecimento significa a "função ou ato psíquico que tem por efeito tornar um objeto presente aos sentidos ou à inteligência", isto é

trazer para o sujeito algo que se põe como objeto, não toda a realidade em si mesmo, mas a sua representação ou imagem, tal como o sujeito a constrói, e na medida das "formas de apreensão" do sujeito correspondente as peculiaridades objetivas. (Reale, 1962, p.48)

A partir dessa definição, temos a existência de vários tipos de conhecimentos: o senso comum, o conhecimento religioso, o conhecimento filosófico e o conhecimento científico. O conhecimento científico se diferencia dos demais níveis de conhecimento por uma série de razões, dentre as quais, a principal corresponde à necessidade de uma ordenação em suas proposições.

Esse ordenamento se dá a partir da relação (de predicação) do pensamento humano com os objetos, por meio da definição de conceitos básicos gerais. Esses conceitos correspondem ao que chamamos de categorias.

Fixemos, então, que as categorias são modos de ser, dados na experiência inevitável das coisas. Elas são impensáveis vazias, porque jamais tivemos a experiência de modo de ser das coisas fora das coisas, sem as coisas, e não podemos pensar sem os materiais da experiência, não pensamos quantidade vazia, não pensamos 
qualidade, relação, senão nas coisas. Não há modo de ser sem o ser. (Campos, 1959, p.27)

$\mathrm{Na}$ filosofia, a teoria geral do conhecimento investiga a relação do nosso pensamento com os objetos em geral. Dentro dela, a teoria especial do conhecimento fica encarregada com a parte referente aos conteúdos do pensamento em que a relação entre o pensamento e os objetos encontra a sua expressão mais elementar, isto é, investiga os conceitos básicos mais gerais, por meio dos quais procuramos definir os objetos. Desse modo, a teoria especial do conhecimento é, por conseguinte, essencialmente, uma teoria das categorias:

A teoria das categorias, observa Volkelt, está em relação estreita com a metafísica; uma e outra investigam os mesmos conceitos, mas a maneira de pôr o problema é essencialmente diferente em ambas as ciências. A teoria das categorias fixa a sua atenção na origem lógica destas formas do pensamento; investiga como brotam estes conceitos das leis essenciais do pensamento em concorrência com o caráter do que é dado empiricamente. Deste modo, fica assente que a teoria das categorias realiza esta investigação exclusivamente do ponto de vista da validade. A discussão da origem lógica das categorias é por sua vez uma explicação do caráter da sua validade.

(Hessen, 1987, p.162)

Dentro da teoria das categorias, temos claramente delineado que a concepção adotada é determinada pela posição epistemológica a qual se adota, sendo essa posição definidora da maneira de adjetivar do sujeito, de demarcar as categorias.

Assim, temos que, se o conhecimento humano for, como coloca Aristóteles, uma reprodução dos objetos, se esses têm uma forma e uma natureza próprias, então, os conceitos fundamentais do conhecimento, as categorias, representam propriedades gerais dos objetos, qualidades objetivas do ser. Por sua vez, se o pensamento produz os objetos, como apresentado por Kant, as categorias são puras determinações do pensamento, formas e funções a priori da consciência. 
Essas duas concepções da essência das categorias são os pilares fundadores do conhecimento científico, e se encontram em contraposição constante: sendo as categorias as formas do ser, propriedades dos objetos; ou formas e determinações do pensamento. A primeira é a concepção realista e objetivista de conhecimento científico; a segunda é o entendimento do conhecimento científico como idealista e apriorista (ver Quadro 1).

Quadro 1 - Categorias segundo a filosofia

\begin{tabular}{|c|c|}
\hline $\begin{array}{c}\text { Categorias como: } \\
\text { Propriedades gerais do objeto } \\
\text { Formas do ser }\end{array}$ & $\begin{array}{c}\text { Categorias como: } \\
\text { Forma e funções } \boldsymbol{a} \text { priori da } \\
\text { consciência }\end{array}$ \\
\hline Empirismo & Racionalismo \\
\hline Realista & Idealista \\
\hline Objetivista & Apriorista \\
\hline Aristóteles & Kant \\
\hline
\end{tabular}

Organização: Adriano Corrêa Maia.

Assim, sendo a geografia uma disciplina do conhecimento científico, temos dentro dela a existência de uma ordenação em suas preposições, isto é, a determinação de categorias que relacionem o objeto geográfico e o pensamento humano. Portanto, a geografia, como um ramo do conhecimento científico, tem que determinar e definir as suas categorias principais, as categorias geográficas. E essas sempre deverão estar balizadas com a teoria do conhecimento e suas definições.

\section{Categorias em geografia (caminhos metodológicos)}

Desde a sua sistematização como um campo do conhecimento científico, a geografia se posicionou na intersecção das ciências exatas e humanas. Como resultado, o pensamento geográfico apresentou 
desde seu princípio uma forte complexidade quanto à sua definição conceitual e metodológica; além de encontrar a dificuldade de assegurar um objeto de estudo próprio, uma vez que esse reunia uma série de objetos comuns à outras ciências.

A partir disso, a geografia passou a adotar como característica teórica/metodológica toda essa complexidade, na medida em que propôs ser uma ciência-ponte ("ciência de síntese") entre os aspectos da natureza e os aspectos da sociedade, ou entre as ciências naturais e as ciências humanas. Desse modo, a episteme geográfica se consolidou como uma disciplina ou ciência (?) cujo objeto de estudo é a relação entre o homem e o meio, concentrando-se no estudo do espaço geográfico.

Partimos então da seguinte consideração: a Geografia como área de conhecimento sempre expressou (desde sua autonomia) sua preocupação com a busca da compreensão da relação do homem com o meio (entendido como entorno natural). Neste sentido ela se diferenciou e se contrapôs as demais ciências, que por força de seus objetos e das classificações, foram individualizadas em Ciências Naturais e Sociais. Este paradoxo acompanha a Geografia, ainda que hoje possa ser seu privilégio. Constitui um paradoxo, porque, na medida em que na Modernidade se expandiu a racionalidade e se constituiu a ciência moderna, o caminho foi a disjunção, a separação, a compartimentação do conhecimento; a divisão entre as ciências naturais e as ciências sociais. (Suertegaray, 2001)

Consequentemente, o desenvolvimento das questões relativas à atribuição de categorias em geografia sempre partiu desse pressuposto:

\section{Objeto de estudo - Relação homem $x$ meio Categoria principal - Espaço geográfico}

Mesmo, portanto, com toda a complexidade teórico-metodológica, a consolidação da geografia como uma disciplina científica exigiu a construção de um sistema de categorias e conceitos particulares, 
com o objetivo de formular um conhecimento prévio de parcela da realidade.

Repetimos que o ato de definir, claramente, o objeto de uma ciência é tambem o ato de construir-lhe um sistema próprio de identificação das categorias analíticas que reproduzem, no âmbito da ideia, a totalidade dos processos, tal como eles se produzem na realidade. [...] A construção de um sistema interior a cada ciência particular só pode ser feita se as categorias da análise são ajustadas às categorias do real. É o chegar a uma síntese e ninguém ignora que sem síntese não há ciência. (Santos, 1978, p.119)

A busca desse nível de teorização dentro do conhecimento geográfico foi possível mediante um esforço de abstração de alguns de seus pensadores, empenho no qual só foi possivel chegar por meio da atribuição de categorias que definem a realidade que se queira abstrair.

Sintetizando a discussão até o momento, temos que para a concessão de categorias em geografia, o objetivo da disciplina é discutir a relação homem/meio por meio do espaço geográfico, consequentemente, o espaço torna-se a categoria central da disciplina, um conceito que expressa a articulação entre natureza e sociedade, o objetivo da disciplina.

Em nosso caso particular isto supõe o reconhecimento de um objeto próprio ao estudo geográfico, mas isso não basta. A identificação do objeto será de pouca significação se não formos capazes de definir-lhe as categorias fundamentais. Sem nenhuma dúvida, as categorias sob um ângulo puramente nominal mudam de significação com a história, mas elas também constituem uma base permanente e, por isso mesmo, um guia permanente para a teorização. Se queremos alcançar bons resultados nesse exercício indispensável devemos centralizar nossas preocupações em torno da categoria - espaço - tal qual ele se apresenta, como um produto histórico. São os fatos referentes à gênese, ao funcionamento e à evolução do espaço que nos interessam em primeiro lugar. (Santos, 1978, p.116-17) 
Definindo o espaço como a categoria principal da geografia, temos a necessidade, para o desenvolvimento de uma análise geográfica, de capturar/apreender a relação dessa categoria com a realidade. Isso se dá por meio das categorias analíticas.

Desse modo, temos que para uma "interpretação" do espaço geográfico - a sua gênese, o seu funcionamento e a sua evolução necessitamos inicialmente conceitualizá-lo, para após delimitarmos as suas categorias analíticas. Sem esse procedimento estaríamos impossibilitados de desmembrar o todo mediante um processo de análise, para reconstruí-lo depois por meio de um processo de síntese. Consequentemente, toda a análise feita dentro da disciplina geográfica parte de uma formulação do conceito de espaço geográfico, uma vez que é a categoria principal e definidora do campo de atuação da área particular da ciência. A importância desse fato é destacada por Harvey (2006, p.129) quando afirma que "naturalmente a própria consideração do espaço e espaço-tempo tem crucial efeito sobre as teorias e entendimentos que particularmente se desenvolvem".

Então, a partir da categoria espaço geográfico e sua definição conceitual, a episteme geográfica vai buscar um arcabouço de categorias operacionais, pois, por meio delas, irão ser realizadas as "leituras" da relação entre o homem e o meio. As categorias analíticas (operacionais) serão as perspectivas balizadoras da geografia.

No desenvolvimento da historia do pensamento, o espaço geográfico encontrou varias definições (Corrêa, 1995), resultando na utilização de várias categorias analíticas. Temos, então, uma conceitualização do espaço geográfico sob diferentes ópticas e, decorrente disso, vários exemplos de categorias analíticas utilizadas para a sua apreensão: a paisagem, o território e o lugar. ${ }^{1}$

Consequentemente, cada conjunção hierárquica (níveis ou camadas) desses conceitos analíticos com a categoria espaço pode expressar uma possibilidade de leitura do espaço geográfico. A partir disso, temos vários caminhos metodológicos dentro do pensamento geográfico, todos objetivando desenvolvimentos metodológicos que

1 Também podemos citar área, ambiente, entre outros. 
busquem capturar a relação do espaço com a sociedade, a relação homem e meio por intermédio do espaço geográfico.

Como exemplo, encontramos o caminho metodológico traçado por Moreira (2007, p.108), que a partir de sua concepção da ciência geográfica traça sua via metodológica pela consideração inicial de "que a ciência é uma forma de representação que vê e organiza o mundo através do conceito, restringindo a relação entre a imagem e a fala a esse nível de representação", e considera a geografia uma forma particular de ciência que tira sua especificidade de relacionar imagem e fala por meio da categoria paisagem.

Continuando, o autor coloca que essa especificidade vem do fato da produção da sua forma de representação de mundo - a geografia concebe o mundo como espaço. Essas duas categorias necessitam para isso mobilizar a categoria operatória intermediaria do território. Então, a paisagem, o território e o espaço formam a tríade das categorias da representação e construção da ideia de mundo da geografia. Moreira (2007) também ressalta que o deslocamento entre estas categorias é realizado pelos princípios lógicos² da geografia, que são indicados: localização, distribuição, extensão, distância, posição e escala.

Paisagem, território e espaço - com o primado no espaço - são assim as categorias da geografia. Analisar espacialmente o fenômeno implica antes descrevê-lo na paisagem e a seguir analisá-lo em termos de território, a fim compreender-se o mundo como espaço. [...] Mas são os princípios lógicos a base dessa base. São eles que criam o espaço, por estarem presentes também nele, convertem a paisagem em território e o território em espaço. (ibidem, p.116-17)

2 Princípio Lógico - "Proposição posta no início de uma dedução, não sendo deduzida de nenhuma outra no sistema considerado e, por conseguinte, colocada até nova ordem fora da discussão. [...] Mas geralmente, chamam-se princípios de uma ciência ao conjunto de proposições diretivas, características, às quais todo o desenvolvimento ulterior deve ser subordinado. Princípio, neste sentido, e principal evocam sobretudo a ideia do que é primeiro em importância e, na ordem do assentimento, do que é 'fundamental'” (Lalande, 1999, p.861). 
Já o desenvolvimento dado por Santos (1978, 1985, 1986) parte da concepção de que o espaço constitui uma realidade objetiva, um produto social em permanente processo de transformação. Com isso, o espaço impõe a sua própria realidade; por isso a sociedade não pode operar fora dele. Sendo assim, para estudar o espaço, é necessário apreender a sua relação com a sociedade, pois é essa que expressa a compreensão dos efeitos dos processos (tempo e mudança). Para isso, Santos (1985) especifica as noções de forma, função e estrutura como elementos fundamentais para a compreensão da produção do espaço; assim, coloca que as categorias analíticas representarão o verdadeiro movimento da totalidade, o que permitirá fragmentá-la para em seguida reconstruí-la. Em outras palavras, as categorias analíticas apropriadas dão a possibilidade de capturar a marca da sociedade sobre a natureza e as relações existentes antes, durante e depois dessa metamorfose. Essas categorias, no desenvolvimento de Santos (1985, p.71), são estrutura, processo, função e forma, que definem o espaço em relação à sociedade. Assim,

forma, função, estrutura e processo são quatro termos disjuntivos, mas associados, a empregar segundo um contexto do mundo de todo dia. Tomados individualmente, representam apenas realidades parciais, limitadas, do mundo. Considerando em conjunto, porém, e relacionados entre si, eles constroem uma base teórica e metodológica a partir da qual podemos discutir os fenômenos espaciais em totalidade.

Também temos, dentro do pensamento geográfico brasileiro, o desenvolvimento dado por Suertegaray (2001) que, pensando a geografia como uma representação que perpassa a interface e a transfiguração da realidade, considera o espaço geográfico um todo uno e múltiplo, aberto a múltiplas conexões que se expressam por meio de diferentes categorias analíticas da geografia, como os conceitos de paisagem, território, lugar e meio. ${ }^{3}$

3 Paisagem - "paisagem como um conceito operacional, ou seja, um conceito que nos permite analisar o espaço geográfico sob uma dimensão, qual seja o da 
Suertegaray (2001) aponta que essas categorias analíticas representam possibilidades para diferentes leituras do espaço, e a totalidade estaria numa interpolação entre todas as leituras. Para retratar a ideia, coloca o espaço geográfico como um círculo, no qual as categorias analíticas são setorizadas em quatro partes (Figura 1), cada parte representando uma visão analítica privilegiada por um ou outro geógrafo.

conjunção de elementos naturais e tecnificados, socioeconômicos e culturais. Ao optarmos pela análise geográfica a partir do conceito de paisagem, poderemos concebê-la enquanto forma (formação) e funcionalidade (organização). Não necessariamente entendendo forma-funcionalidade como uma relação de causa e efeito, mas percebendo-a como um processo de constituição e reconstituição de formas na sua conjugação com a dinâmica social. Neste sentido, a paisagem pode ser analisada como a materialização das condições sociais de existência diacrônica e sincronicamente. Nela poderão persistir elementos naturais, embora já transfigurados (ou natureza artificializada). O conceito de paisagem privilegia a coexistência de objetos e ações sociais na sua face econômica e cultural manifesta" (Suertegaray, 2001).

Território - "o conceito de Território, tratamos o espaço geográfico a partir de uma concepção que privilegia o político ou a dominação-apropriação. Historicamente, o território na Geografia foi pensado, definido e delimitado a partir de relações de poder. Observa-se que, historicamente, a concepção de território associa-se a ideia de natureza e sociedade configuradas por um limite de extensão do poder.Para este autor, 'territórios são no fundo relações sociais projetadas no espaço'. Por consequência, estes espaços concretos podem formar-se ou dissolver-se de modo muito rápido, podendo ter existência regular, porém periódica, podendo o substrato material permanecer o mesmo" (Suertegaray, 2001).

Lugar - o conceito de "Lugar constitui a dimensão da existência que se manifesta através 'de um cotidiano compartido entre as mais diversas pessoas, firmas, instituições-cooperação e conflito são a base da vida em comum' (Santos, 1997). O conceito de lugar induz a análise geográfica a uma outra dimensão - a da existência - 'pois refere-se a um tratamento geográfico do mundo vivido' (Santos, 1997). Este tratamento vem assumindo diferentes dimensões. Mas o lugar pode também ser trabalhado na perspectiva de um mundo vivido, que leve em conta outras dimensões do espaço geográfico, conforme se refere Santos (1997), quais sejam os objetos, as ações, a técnica, o tempo" (Suertegaray, 2001). 


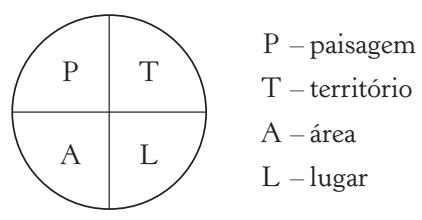

Figura 1 - Categorias operacionais do espaço na visão de Suertegaray (2001).

O espaço geográfico é representado pelo movimento do círculo, no qual seu giro expressa a ideia de um espaço geográfico com um todo uno, múltiplo e complexo. Essa representação é elaborada no sentido de expressar a concepção de que:

o espaço geográfico pode ser lido através do conceito de paisagem e ou território, e ou lugar, e ou ambiente; sem desconhecermos que cada uma dessas dimensões está contida em todas as demais. Paisagens contêm territórios que contêm lugares que contêm ambientes valendo, para cada um, todas as conexões possíveis. (Suertegaray, 2001)

Suertegaray (2001) acredita que essa concepção teórica metodológica abre possibilidades analíticas para a geografia, que possibilita uma frutífera articulação com as conexões derivadas da fronteira tênue entre cada um desses conceitos.

A partir dos debates e desenvolvimentos dos caminhos metodológicos apresentados, observamos que o busca de categorias metodológicas é de extrema importância para um trabalho de análise dentro da ciência geográfica. Decorrente em nossas pesquisas de caráter geográfico, verifica-se a necessidade de definição das categorias e os caminhos metodológicos que estruturam nossa base teóricometodológica. Essas definições devem ser pautadas por alguns pontos-chave, que propiciam uma análise realmente geográfica dos nossos objetos de estudo. Esses pontos, em nosso entendimento, são:

1) a definição de que a geografia se caracteriza como tendo por objeto de estudo as relações entre o homem e o meio (natureza), se concentrando assim no estudo do espaço geográfico, a categoria principal da ciência geográfica; 
2) a definição conceitual de espaço geográfico (categoria principal) é de vital importância para o desenvolvimento das categorias operacionais;

3) as categorias operacionais são as categorias que assumiremos para "captura" desse espaço;

4) a definição de um apropriado caminho metodológico que faz a transposição entre a categoria de espaço (categoria principal) e as categorias analíticas (operatórias);

5) a definição das categorias auxiliares. ${ }^{4}$

\section{Determinação relacional de categorias - uma proposta de caminho epistemológico- metodológico}

Após a discussão sobre as categorias dentro da geografia, vamos propor um caminho metodológico que permita uma aproximação da realidade, quando objetivamos fazer uma análise geográfica da relação urbano-rural no espaço urbano.

Partimos da seguinte proposição: para fazermos uma análise geográfica da relação rural-urbano temos que investigar como se dá a relação homem-meio no espaço geográfico. Como o espaço geográfico é uma categoria que expressa a articulação da natureza com a sociedade, e é a categoria máxima da geografia, temos que capturá-la, em sua unicidade de objeto e na sua multiplicidade de elementos caracterizadores.

Para a construção do nosso caminho metodológico existe a necessidade de encaminharmos a definição de alguns pontos:

1) qual a definição de espaço que tomaremos;

2) quais categorias operatórias assumiremos para a "captura" desse espaço;

3) qual caminho metodológico que faz a transposição entre a categoria de espaço e as categorias operatórias;

4) qual a definição das subcategorias como rural e urbano.

4 Chamamos de categorias auxiliares as categorias que não são geográficas. 


\section{A definição de espaço}

Para a definição de espaço geográfico, partiremos da concepção proposta por Harvey (1980, 2006). Em Justiça social e a cidade, Harvey (1980) argumenta que é de essencial importância refletir sobre a natureza do espaço, uma vez que, somente a partir dessas reflexões bem consolidadas, é que poderemos ter ferramentas para um possível entendimento dos processos espaciais.

Assim, Harvey (1973, p.3-4) define uma divisão tripartida para o modo de entendimento do conceito de espaço:

Se tomarmos o espaço como absoluto ele se torna uma "coisa em si mesma" com uma existência independente da matéria. Ele possui então uma estrutura que podemos utilizar para clarificar ou para individualizar fenômenos. A característica de um espaço relativo propõe que ele deve ser entendido como uma relação entre objetos, a qual existe somente porque os objetos existem e se relacionam. Há outra acepção segundo a qual o espaço pode ser tomado como relativo, e proponho chamá-lo espaço relacional espaço tomado, à maneira de Leibniz, como estando contido em objetos, no sentido de que um objeto existe somente na medida em que contém e representa dentro de si próprio as relações com outros objetos.

O entendimento do espaço-tempo de Harvey compreende os espaços absoluto, relativo e relacional. Com essa divisão tripartida do espaço, propõe que o método de aproximação espaço-tempo mais profícuo é uma questão resolvida por meio do contexto empírico no qual queremos relacionar. Portanto, a essência do conceito de espaço está na relação dialética entre os termos. Como exemplo, analisa a Basílica de Sacre Coeur em Paris (Harvey, 1979), onde "era impossível somente um entendimento político-econômico de origem sobre a temática sem levar em conta outras relações perspectivas" (Harvey, 2006, p.125). 
Desse modo, a aproximação espacial colocada por Harvey não possui uma resposta ontológica para a sua questão, e que em seu conceito de espaço geográfico os três espaços estão presentes.

espaço é nem absoluto, relativo ou relacional nele mesmo, mas ele pode torna-se um ou todos simultaneamente dependendo das circunstâncias. O problema de propor uma conceitualização do espaço esta resolvida dentro da prática humana com respeito a ele. Em outras palavras, não há perguntas filosóficas para questões filosóficas levantadas sobre a natureza do espaço - a resposta está na prática humana. A questão "o que é espaço?" é consequententente substituída pela questão "como é que diferentes práticas humanas criam e fazem uso de diferentes conceitualizações do espaço?". A relação de propriedade, por exemplo, cria espaços absolutos dentro dos quais o controle monopolítico pode operar. O movimento de pessoas, bens, serviços e informações ocorrem no espaço relativo, porque eles pegam dinheiro, tempo, energia e similares para superar a fricção da distância. Parcelas de terra também capturam benefícios porque contêm relações com outras parcelas ... na forma de aluguel o espaço relacional torna-se, dentro dele mesmo, um importante aspecto de prática social humana. (Harvey, 1980, p.4-5)

Temos, portanto, que a opção de utilização de uma ou outra concepção de espaço está subordinada à natureza do fenômeno investigado, sendo que o elemento principal está na consideração de que os três espaços permaneçam em uma constante tensão dialética

Essa conceituação de espaço geográfico permite um salto sobre a liminaridade da espacialidade, uma vez que estamos de modo inexorável situados dentro das três estruturas simultaneamente.

Nas análises da relação urbano-rural, temos que a visão relacional de espaço constitui-se uma ferramenta de análise importante, e proporciona alternativas analíticas para o modo tradicional e positivista de geografia, que limitou a visão espacial da relação, uma vez que se concentrou exclusivamente sobre o espaço absoluto e relativo e sobre o aspecto material e conceitual do espaço-tempo (evitando o vivido e o relacional). 


\section{As categorias de "captura" do espaço}

De todas as categorias analíticas empregadas na geografia, temos que para o nosso desenvolvimento teórico-metodológico sobre a análise da relação rural-urbano o conceito de lugar seria o mais apropriado.

A utilização do conceito se dá em razão do caráter relacional e social (Harvey, 1996), que possibilitam a captura das novas dinâmicas geradas na interseção entre o rural e o urbano. Desse modo, podemos compreender o rural e o urbano e suas interseções tanto como localizações (espaço absoluto), quanto como configurações de "permanências" relativas internamente heterogêneas (espaço relativo), dialética contida na dinâmica geral de espaço-tempo de processos socioecológicos (espaço relacional), ou seja, processos específicos contidos e expressos dentro do processo global.

Consequentemente, essa conceituação de lugar permite analisar as dinâmicas da relação rural e urbano em sua inter-relação, uma vez que considera o espaço geográfico não somente por seu ambiente físico (espaço absoluto), mas também pelas diferentes respostas humanas (espaço relativo e relacional) às oportunidades e limitações apresentadas pelos ambientes.

Assim, a conceituação de lugar proposta irá abordar as questões em termos da relação entre processos gerais e questões particulares (Massey, 1984, 2008). A ideia de lugares com limites fechados e identidades únicas, construídas por meio de relações profundas e históricas, que permitia a análise do rural e o urbano como "elementos" físicos e sociais "estáticos", não se adapta a essa conceituação. Aqui, o lugar não possui um sentido único compartilhado por todos, do mesmo modo que as pessoas não possuem uma identidade única, mas a identidade dos lugares vai ser explicada no plural, pois os lugares vão possuir diversas identidades e vão estar repletos de relações com o meio, o mundo; é nesse sentido que vamos ter um sentido global de lugar (Massey, 1994).

Desse modo, "o que dá ao lugar sua especificidade não é algum tipo de história longamente internalizada, mas o fato de que ele é 
construído a partir de uma constelação particular de relações sociais que se encontram e se enlaçam num lócus particular" (Massey, 1994, p.322). Lugares serão, portanto, pontos de encontro de redes de relações sociais, movimentos e comunicações cujas relações recíprocas tenham sido construídas em escala muito maior do que aquelas definidas para o lugar naquele momento. Essas relações com o sistema amplo não são apenas ritualísticas, mas relações reais com conteúdos econômicos, políticos e culturais reais.

Assim, pela relação do conceito de espaço (como uma trialética dos espaços absoluto, relativo e relacional) com o lugar, pretendemos buscar a compreensão profunda e multifacetada da expressão espacial da relação rural/urbano. Portanto, para compreender o lugar temos que buscar o entendimento de como o rural e o urbano dialeticamente constroem esse espaço, por meio de elementos políticos, econômicos, culturais e vivências expressas localmente, mas nunca deixando de lado as relações estruturais globais na qual o rural e o urbano também estão inseridos.

\section{O caminho metodológico que nos leva do espaço geográfico as categoriais analíticas}

Diferentemente do caminho lógico-metodológico, ${ }^{5}$ utilizado correntemente nos desenvolvimentos epistemológicos dentro da ciência geográfica, vamos relacionar o espaço geográfico - definido pela matriz espacial de Harvey - com a categoria analítica de lugar por um caminho epistemológico-metodológico (Silva, 1986).

Fundamentado em nosso objetivo principal - a apreensão do entendimento da essência do espaço - partimos (e chegamos) na seguinte proposição "a forma espacial é a expressão do lugar, que é a riqueza real, assim como a população que o habita e trabalha" (Silva, 1986, p.95). Consequentemente, "caberia à Geografia descrever e

5 O caminho lógico-metodológico corresponde em estruturar as categorias, de forma lógica, com os níveis de entendimento do pensamento humano, como o universal, o singular e o particular. 
explicar esse espaço, pois é de espaço que se trata, mostrando que a forma espacial é apenas a manifestação visível (ou não) do espaço - superfície da terra - a paisagem percebida. Ora, trata-se de compreendê-la" (ibidem).

Assim, pela matriz espacial de Harvey temos a possibilidade de apreensão da unidade do objeto. Vejamos como perpassamos o caminho epistemológico-metodológico:

- "há um espaço absoluto, abstrato. Podemos propô-lo concreto, relacionado à materialidade do mundo", esse espaço é o lugar;

- há um espaço relativo que se refere a uma relação entre objetos, "que existe somente porque os objetos existem e se relacionam”. Do primeiro pressuposto, decorre que as relações são também materiais porque os objetos o são, o lugar;

- há um espaço relacional, "à maneira de Leibniz", que se refere aos objetos, sendo contidos por estes: "um objeto existe somente na medida em que contém e representa dentro de si as relações com outros objetos", desse modo, o espaço relacional é também material, como consequência dos pressupostos anteriores, o lugar.

Resultante desse caminho, temos que os lugares e as relações de que trata a geografia são sempre materiais e se expressam em uma forma espacial que é o espaço concreto e "Esse espaço concreto é em parte empírico" (Silva, 1986, p.95-6).

\section{A definição das categorias auxiliares como rural e urbano}

Resultante de reflexões anteriores sobre a relação rural-urbano (Maia, 2009a, 2009b), temos definido alguns parâmetros, que serão balizadores para as análises sobre o espaço dentro dessa relação.

O mais importante é a separação entre rural-urbano e campocidade com as seguintes definições e distinções: campo e cidade como formas concretas, materializadas e compostas de paisagens 
produzidas pelo homem; urbano e rural como representações sociais, conteúdos das práticas de cada sujeito, cada instituição, cada agente na sociedade. Assim, abandonaremos o vínculo direto entre espaço-forma e rural, ou espaço-forma e urbano. Com isso, tais categorias serão desvinculadas entre si, adquirindo o conteúdo analítico desejado dentro do nosso estudo.

Biazzo (2007) também mostra esse caminho quando propõe a distinção do rural e urbano do seu conteúdo concreto e passa a tratá-los por meio das ruralidades e das urbanidades. Com isso, urbanidades e ruralidades se combinam em cada recorte do espaço geográfico, mais do que isso, se combinam nos atos e na visão de mundo de cada individuo, são atributos, não substantivos.

Conforme analisado em estudo prévio, em ambos os espaços se manifestam identidades sociais que configuram ruralidades e urbanidades. Em paisagens do campo e das cidades (formas, conjuntos de objetos) existem urbanidades e ruralidades (conteúdos-heranças, origens, hábitos, relações, conjuntos de ações) que se combinam, gerando novas territorialidades, admitindo-se que cada local ou região pode abrigar diferentes territorialidades superpostas, relativas a diferentes agentes sociais. Para reforçar essa busca por uma nova visão, sustenta-se que não há espaços rurais ou espaços urbanos. Há urbanidades e ruralidades que, combinadas, ensejam as territorialidades particulares de cada localidade, município ou recorte regional. Trata-se de não encarar rural e urbano como substantivos, pois desta forma nada especificam e seu significado se esvazia. (Biazzo, 2007, p.19)

Assim, temos a definição de rural e urbano como categorias sociológicas, que expressam comportamentos socioculturais, sendo assim categorias auxiliares ${ }^{6}$ que vão interagir com as categorias geográficas, formando a base teórica das análises.

6 Categorias auxiliares denominamos as categorias não geográficas e que auxiliam nas análises das categorias geográficas. 
Dessa maneira, temos numa análise geográfica da relação ruralurbano que a categoria principal é o espaço geográfico, a categoria operatória sendo o lugar e rural e urbano tendo a função de "categorias auxiliares" (conforme Quadro 2), mas sempre lembrando que para utilizá-las juntamente com as categorias geográficas e operatórias teremos que fazer uma integração entre a imaginação geográfica e a imaginação sociológica (como proposta por Harvey no capitulo II de Justiça social e a cidade).

Quadro 2 - Proposta de categorias para uma análise geográfica da relação ruralurbano

\begin{tabular}{|c|c|}
\hline Categoria principal & Espaço geográfico \\
\hline Categoria operatória & Lugar \\
\hline Categorias "auxiliares" & Rural \\
& Urbano \\
\hline
\end{tabular}

Organização: Adriano Corrêa Maia.

Em consequência desse desenvolvimento, podemos analisar as interações entre o rural e o urbano em um mesmo espaço, uma vez que sendo constructos socioculturais vão estar mutuamente presentes, interagindo e disputando a hegemonia do lugar. Assim, as análises que relacionam elementos do rural e do urbano não podem ser realizadas com a negligência de suas intenções dialéticas, pois as dinâmicas dessas construções refletem e condicionam o espaço.

\section{Considerações finais}

Apresentamos a discussão das categorias na ciência geográfica com o objetivo de propor um caminho teórico-metodológico que procure mostrar como a relação rural-urbano pode ser considerada a partir de um referencial relacional na análise do espaço, com isso possibilitando o encontro de "novos" elementos embasadores para a construção teórica da relação do rural com o urbano. 
Considerando o lugar constituído pelos espaços absoluto, relativo e relacional em sua expressão trialética, temos que conformase uma expressão única, composta pelo "encontro de trajetórias" (Massey, 2008), com vários elementos político-sociais, sendo assim, um elemento híbrido em disputa pelo seu domínio (Rose, 1994), no qual o rural e o urbano estariam na sua base.

Pela relação do conceito de espaço (como uma trialética dos espaços absoluto, relativo e relacional) com o lugar, temos a compreensão profunda e multifacetada da expressão espacial da relação rural/urbano. Portanto, para compreender o lugar, temos que buscar o entendimento de como o rural e o urbano dialeticamente constroem esse espaço, mediante elementos políticos, econômicos, culturais e vivências expressas localmente, mas nunca deixando de lado as relações estruturais globais na qual o rural e o urbano também estão inseridos.

Com um desenvolvimento teórico, a partir da matriz espacial, proposta por David Harvey, que qualifica relacionalmente a construção do lugar, mostramos que os conceitos de rural e o urbano estão presentes e são estruturadores do espaço, de uma maneira trialética construindo de forma perspectiva o lugar. Assim, podemos falar de uma perspectivação, para indicar que todo o desenvolvimento dado durante o texto tem a intenção de possibilitar um "outro" modo de análise da relação rural-urbano no espaço geográfico, de forma que seja sobre uma óptica perspectiva do espaço, isto em razão de a conceituação de espaço colocada sempre ser pautada por um modo relacional e contextual; assim sendo, o contexto, tanto empírico como abstrato, do conceito de espaço é o determinador de sua "realidade", e consequentemente perspectivador do lugar.

Para finalizar, queremos deixar claro que esse desenvolvimento teórico-metodológico reflete um primeiro momento de reflexão sobre a temática da relação rural e urbano no espaço geográfico. Sendo assim, o próximo passo é a avaliação empírica de toda esta explanação. 


\section{Referências}

ABBAGNANO, N. Dicionário de filosofia. São Paulo: Martins Fontes, 2000.

BIAZZO, P. P. Campo e rural, cidade e urbano: distinções necessárias para uma perspectiva crítica em Geografia Agrária. In: MARAFON, G. J.; PESSÔA, V. L. S (Org.) Interações geográficas: a conexão interinstitucional de grupos de pesquisa. Uberlândia: Roma, 2007, p.10-22.

CAMPOS, C. Ensaios sobre a teoria do conhecimento. Belo Horizonte: Cardal, 1959.

CORRÊA, R. L. Espaço, um conceito-chave da geografia. In: CASTRO, I. E. et al. Geografia: conceitos e temas. Rio de Janeiro: Bertrand, 1995.

HARVEY, D. Explanation in geography. London: Edward Arnold, 1969. Monument and Myth. Annals of the association of American Geographers, v.69. n.3, p.362-81, 1979.

. A justiça social e a cidade. São Paulo: Hucitec, 1980.

Justice, nature and the geography of difference. Massachusetts: Blackwell, 1996

. Spaces of Global Capitalism. London: Verso, 2006.

HESSEN, J. Teoria do conhecimento. Coimbra: Armenio Amado, 1987.

LALANDE, A. Vocabulário técnico e crítico da filosofia. São Paulo: Martins Fontes, 1999.

MAIA, A. C. Cultura e relação rural-urbano: considerações teóricas e o caso dos migrantes mineiros em Rio Claro-SP. In: XIX ENCONTRO NACIONAL DE GEOGRAFIA AGRÁRIA, 2009a (no prelo).

Produção do espaço e cultura: a relação rural-urbano e o caso dos migrantes mineiros em Rio Claro-SP. In: XII ENCUENTRO DE GEÓGRAFOS DE AMÉRICA LATINA, 2009b (no prelo).

MASSEY, D. Introduction: Geography matters. In: MASSEY, D.; ALLEN, J. (Ed.) Geography Matters! a reader. Cambridge: Cambridge University Press, 1984, p.1-11.

Pelo espaço. Rio de Janeiro: Bertrand Brasil, 2008.

MOREIRA, R. Pensar e ser em geografia: ensaios de história, epistemologia e ontologia do espaço geográfico. São Paulo: Contexto, 2007.

REALE, M. Filosofia do direito. São Paulo: Saraiva, 1962.

ROSE, G. The cultural politics of place: local representation and oppositional discurse in two films. Transactions of the Institute of British Geographers, v.19, n.1, p.46-60, 1994. 
SANTOS, M. Por uma geografia nova: da crítica da Geografia a uma Geografia crítica. São Paulo: Hucitec, 1978.

. Espaço e método. São Paulo: Nobel, 1985.

SILVA, A. C. De que é o pedaço? Espaço e cultura. São Paulo: Hucitec, 1986. SUERTEGARAY, D. M. A. Espaço geográfico uno e múltiplo. Scripta Nova, n.93, 15 de julho de 2001. Disponível em: <http://www.ub.es/ geocrit/sn-93.htm>. 


\section{1 \\ As BASES TEÓRICAS \\ DA GEOGRAFIA AGRÁRIA BRASILEIRA: O Pensamento de PierRe MONBeig e Leo Waibel}

Flamarion Dutra Alves*

\section{Introdução}

O principal objetivo deste texto é fazer uma retrospectiva dos principais autores que contribuíram para a construção da geografia agrária brasileira, sendo geógrafos ou outros cientistas de outras áreas do conhecimento. Nessa discussão, as análises estarão focadas em dois geógrafos que ajudaram a fundar e consolidar a geografia agrária no Brasil, o francês Pierre Monbeig e o alemão Leo Waibel.

A ideia desse debate é resgatar a memória e o pensamento da geografia agrária brasileira, mostrando um pouco da biografia dos autores, seus fundamentos teórico-metodológicos, temáticas estudadas e técnicas de pesquisas utilizadas, a fim de entender a evolução/ transformação do pensamento agrário na ciência geográfica.

\section{Geografia universitária no Brasil}

A geografia universitária brasileira surge na década de 1930, com a vinda de geógrafos franceses para criarem os cursos de Geografia em São Paulo e Rio de Janeiro, 1934 e 1935, respectivamente. Durante a mesma década, foram criados outros órgãos ligados à ciência geo-

\footnotetext{
* Doutorando em Geografia e integrante do Núcleo de Estudos Agrários (NEA), Unesp - Rio Claro (SP).
} 
gráfica que fundaram definitivamente a geografia brasileira, como em 1933 da criação do Conselho Nacional de Geografia (CNG), em 1934 a Associação dos Geógrafos Brasileiros (AGB) fundada por Pierre Deffontaines, e no ano de 1938 o Instituto Brasileiro de Geografia e Estatística (IBGE).

A geografia agrária, assim como a geografia humana como um todo, esteve embasada nos pressupostos metodológicos franceses ligados aos estudos regionais de Paul Vidal de La Blache e Albert Demangeon que estimularam vários geógrafos, entre eles Pierre Monbeig, Pierre Deffontaines, Francis Ruellan, entre outros.

Os pressupostos teóricos alemães influenciaram com intensidade menor a geografia brasileira, pode-se citar a geopolítica de Frederic Ratzel que serviu de base nos estudos de Everardo Backheuser, que foi um dos influentes na criação do IBGE. Outro geógrafo alemão com destaque no Brasil é Leo Waibel, trazido ao país a cargo do Conselho Nacional de Geografia para realização de estudos nas frentes pioneiras, formou diversos discípulos, entre eles Orlando Valverde.

Nas décadas de 1940 e 1950, os maiores expoentes da geografia agrária e dos estudos humanos foram Pasquale Petrone, Ary França, Nilo Bernardes e Lysia Bernardes, os quais tiveram a vertente francesa como fonte das pesquisas geográficas. Orlando Valverde e Leo Waibel foram os mais renomados geógrafos que seguiram as linhas gerais do pensamento geográfico alemão.

Nesse sentido, o texto tentará mostrar de forma sintética alguns pontos da influência francesa e alemã no Brasil, analisando a obra de Pierre Monbeig e Leo Waibel no que tange a metodologia, as técnicas, os uso de teorias e conceitos, e como esses pressupostos teóricometodológicos contribuíram para a geografia agrária brasileira.

\section{Pierre Monbeig: pressupostos teórico- metodológicos franceses e a contribuição para a geografia agrária brasileira}

Um dos maiores nomes na geografia agrária brasileira foi, sem dúvida, Pierre Monbeig (Foto 1), discípulo dos ensinamentos de 
Albert Demangeon, que se inspirou nas bases metodológicas sistematizadas de Paul Vidal de La Blache, desenvolveu no Brasil seus mais importantes trabalhos geográficos.

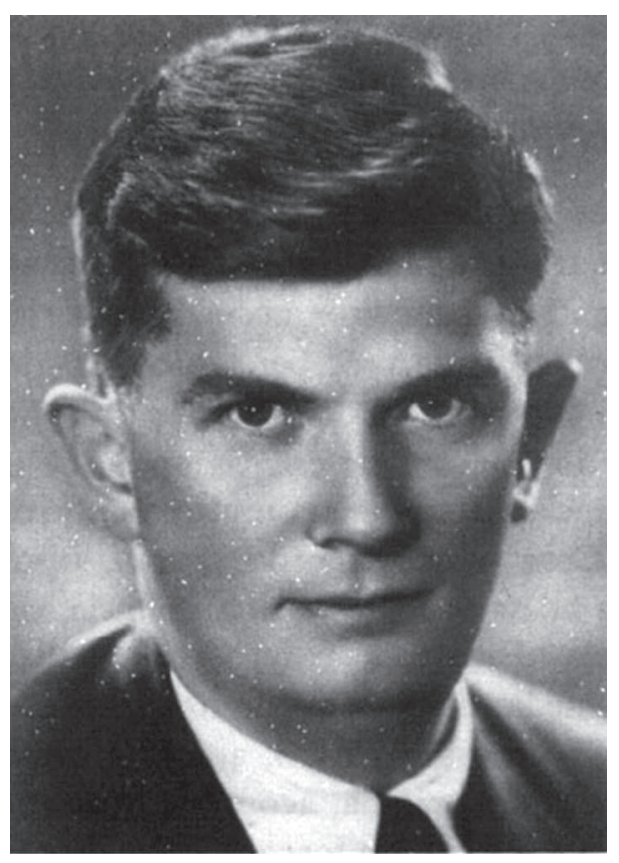

Foto 1 - Pierre Monbeig.

Fonte: Ab’Sáber (1994).

Pierre Monbeig (1908-1987) esteve no Brasil de 1935 a 1946, na fundação do curso de Geografia na Universidade de São Paulo. Durante esse período, publicou diversos artigos nos periódicos em geografia e dois livros, Ensaios de geografia humana brasileira e La crise des sciences de L'homme (Monbeig, 1940, 1943). Após sua volta à França, publicou mais quatro livros: Novos estudos de geografia humana brasileira, Le Brésil, La croissance de la ville de São Paulo e Pioneiros e fazendeiros de São Paulo; este último, resultado de sua tese de doutorado defendida e premiada na Sorbonne, no ano de 1950. 
Em sua metodologia, ressaltem-se os estudos regionais e monográficos, oriundos dos intensos e bem descritos trabalhos de campo:

A prática vidaliana de trabalho de campo e a incorporação em suas pesquisas mostram muito bem como o "terrain", em certa medida, substitui o livro, o texto e, até mesmo, o arquivo histórico. Ele adquire um valor heurístico fundamental, visto que constitui o substrato no qual se lê a relação homem/meio, que se torna, a partir do início do século XX, a problemática explícita da geografia humana francesa. (Dantas, 2005, p.26)

Silvio Bray $(1980,1987,2008)$ entende que Pierre Monbeig desenvolveu seus trabalhos no Brasil sob a óptica do positivismofuncinalista-culturalista. A respeito do funcionalismo na geografia brasileira, ele exemplifica:

Na geografia brasileira, a interpretação funcionalista normalmente apresentou-se sensível aos problemas geográficos de mudança no espaço, como é o exemplo do trabalho clássico de Monbeig (1952) "Pionniers et Planteurs de São Paulo". Essa preocupação com a dinâmica espacial e os arranjos da "fisiologia das paisagens" e das "alterações" e "persistências" dos elementos geográficos tem sido utilizada para explicar as organizações atuais, através de um perspectiva pluricausal. (Bray, 1980, p.40)

Com relação à perspectiva positivista-funcionalista-culturalista, entende-se que foi Positivista, pois se atentou à observação e aos fatos concretos e não abstratos, com ênfase ao empírico. A questão Funcionalista no seu método abarca elementos da sociedade, os quais exercem funções sociais que determinam correlações diretas e indiretas; numa abordagem sistêmica do espaço, essa relação estaria em constante harmonia e conformidade. Por último, a perspectiva Culturalista, que valoriza os aspectos humanos, na sua organização, modos e gêneros de vida. 
Esse conjunto de perspectivas acadêmicas trabalhadas por Pierre Monbeig aprimorou o conceito por ele utilizado na explicação dos fatos geográficos, a noção de Complexo geográfico:

Monbeig, desenvolveu o complexo geográfico como um sistema funcional-estrutural. O sistema funcional-estrutural da escola francesa de geografia positivista funcionalista-culturalista, tem por base o sistema biológico. No sistema biológico-organicista, o todo orgânico encontra-se regido pelas diferentes funções das diferentes partes. Portanto, a noção de sistema funcional-estrutural na geografia funcionalista-culturalista tem como paradigma o modelo biológico. Mas, queremos salientar, que a geografia não utiliza o modelo biológico como analogia - pois os fatos geográficos são diferentes dos fatos biológicos - e sim, utiliza-o como referência. (Bray, 2008, p.4)

A relação do meio físico com os elementos humanos é exaltada na obra de Monbeig; ele não dissocia os impactos e as dinâmicas do domínio físico sobre o homem, entretanto são condições que alteram os modos de vida das populações. Porém, não é determinante quanto sua vivência, apenas devem ser considerados para entender determinadas situações daquele modo de vida existente.

Ainda sobre a questão metodológica de Pierre Monbeig, Bray (1987, p.120) faz uma análise das obras e do método de pesquisa:

A obra mais expressiva quanto ao seu método de investigação e de interpretação é "Pioneiros e fazendeiros de São Paulo". Entretanto, o livro mais significativo quanto às suas ideias geográficas e à sua visão de mundo, encontra-se em "Novos estudos de geografia humana brasileira", contendo coletânea de expressivos artigos publicados em periódicos nacionais, nas décadas de 30, 40 e 50 .

As obras de Pierre Monbeig destacaram a importância do trabalho de campo na geografia, ressaltando os aspectos observáveis e vividos pelo geógrafo na prática empírica. Essas características são 
fundamentais para Monbeig na compreensão dos modos e gêneros de vida, elementos básicos da geografia regional francesa.

A categoria de análise na obra de Monbeig centra-se no estudo da paisagem, seus aspectos naturais e culturais. Baseado na perspectiva lablachiana, o autor segue as concepções da escola francesa:

Ver como a paisagem é reflexo da civilização, tal é uma das principais tarefas do geógrafo; é um trabalho de análise que ele precisa fazer para distinguir o que provém do solo, do clima e também da técnica agrícola, da organização social. A análise da paisagem apresenta-se como um jogo de quebra-cabeças; mas, enquanto o jogo se torna logo fastidioso, é apaixonante o estudo da paisagem: apaixonante porque nos põe em contato com a humilde tarefa quotidiana $e$ milenar das sociedades humanas; ela mostra o homem lutando sem cessar para aperfeiçoar-se. (Monbeig, 1940, p.248)

As temáticas analisadas por Pierre Monbeig perpassam vários assuntos da geografia humana. Salientamos na geografia agrária a expansão cafeeira no interior de São Paulo e Paraná e sua correlação com a construção de ferrovias e cidades ao longo desse front. Bem como, temas ligados aos gêneros de vida de diferentes regiões analisadas em suas pesquisas quando esteve no Brasil, tratando especialmente do habitat rural, conceito muito utilizado entre as décadas de 1930 a 1960, em razão da forte influência lablachiana.

A abordagem histórica foi bem trabalha por Pierre Monbeig na questão dos estudos regionais; sobre isso ele faz algumas observações a respeito dos métodos científicos nos estudos geográficos, lembrando do método histórico "Basta citar a obra de Vidal de La Blache e seus discípulos para avaliar-se o papel essencial que o espírito e o método histórico devem desempenhar nos estudos e pesquisas geográficas" (Monbeig, 1944, p.9). Ao tratar a inter-relação da geografia humana e a história, Monbeig (1944a, p.9) cita Albert Demangeon "a geografia humana estuda as relações entre as sociedades humanas e o meio no presente e no passado". Ainda nos lastros teóricos de Pierre Monbeig, menciona-se o trabalho de Georges para exemplificar o método da geografia humana: 
É preciso simplesmente procurar explicar o gênero de vida atual analisando seus elementos à luz do método histórico que é o único a fazer compreender o lugar que ocupam hoje [...] o estudo de um gênero de vida é a aplicação de método histórico à atualidade regional. (ibidem, p.10)

O autor ainda alerta para o uso indevido do método histórico nas pesquisas geográficas:

A interpretação da história e da geografia é, pois, geral e constante, uma pesquisa de geografia humana não tendo senão um resultado incompleto e um valor científico limitado se aquele que a realiza não tem, além do espírito geográfico, uma mentalidade histórica. (ibidem)

Baseado em Demangeon, Pierre Monbeig (1945c, p.165-6) destaca três pilares metodológicos da geografia, "o primeiro é que a geografia localiza [...] em segundo lugar, a geografia descreve [...] depois de ter localizado, depois de ter descrito, o geógrafo compara", ou seja, a ferramenta principal do geógrafo é observação, na qual ele realiza um processo de descrição do que ele vê e a partir disso faz relações com outras paisagens ou elementos (Organograma 1).

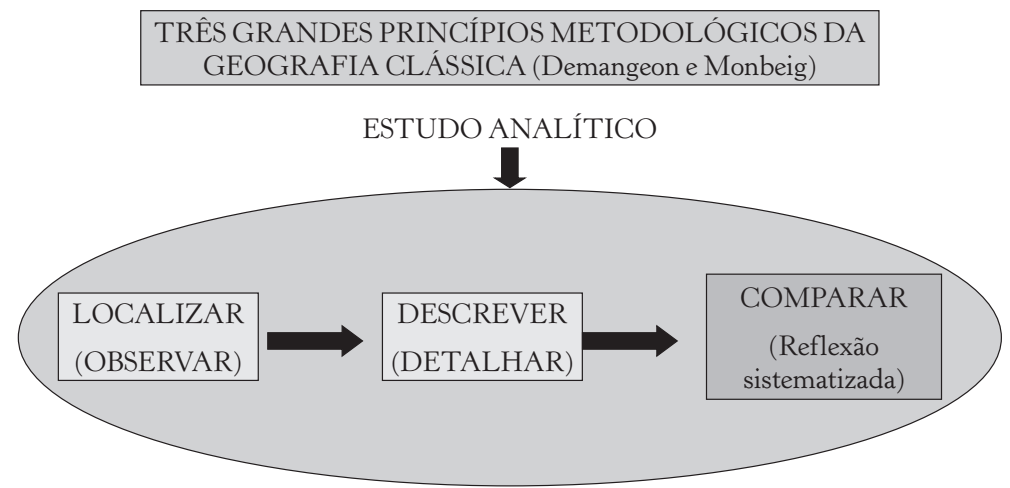

Organograma 1 - Síntese metodológica do geógrafo clássico conforme Monbeig e Demangeon (Alves \& Ferreira, 2008, p.55). 
Diferentemente da síntese explicativa da região, Monbeig e Demangeon conferem uma análise comparativa entre diferentes regiões, possibilitando um conhecimento maior das realidades. Sobre esse procedimento metodológico Monbeig (1945c, p.166) ainda diz que "o método comparativo ajuda ao mesmo tempo a fazer perceber aos jovens espíritos a transformação perpétua das coisas e das sociedades humanas". Ele ressalta que para fazer tais comparações o geógrafo deve desenvolver a capacidade de observar:

sem exagero, que a geografia é a arte de saber ver: saber ver a paisagem, saber ver um mapa, uma fotografia. Esse estudo analítico das paisagens ou de suas reproduções, que é feito por uma leitura atenciosa e precisa, constitui um excelente exercício de observação [...] a observação é a fase inicial da descrição e isso conduz a uma reflexão sistematizada. (ibidem, p.166)

Após as duas etapas iniciais, o geógrafo depara-se com a análise comparativa. A respeito desse método Monbeig (1945c) afirma que "a utilização do método comparativo permitirá assinalar que existem casos análogos, mas nunca casos perfeitamente idênticos. Imediatamente, aparecerá a ideia da multiplicidade das causas tanto quanto de seus efeitos", ou seja, a comparação serve como uma ferramenta para desenvolver ideias em regiões, paisagens ou estudos conhecidos.

Pierre Monbeig (1945d, p.915) reafirma a importância dos estudos regionais para a geografia a fim de conhecer e compreender a realidade:

É, entretanto, no quadro da região que melhor se entra em contato com a realidade: a complexidade das relações entre os grupos humanos e as condições naturais aparece em maior destaque que em golpes de vista de conjunto. O estudo é essencialmente analítico, tratando sucessivamente dos diferentes aspectos físicos e depois dos fatos humanos; não se limita a uma descrição seca e não exclui uma conclusão onde for possível trazer a luz o ajustamento ou, ao contrário, o desajustamento entre as condições geográficas permanentes e o estado atual das atividades humanas. 
Essa abordagem regional pelo método indutivo é latente nas pesquisas da geografia clássica ou tradicional; sobre as questões metodológicas da geografia humana, Monbeig (1946, p.1268) define o padrão metódico da escola clássica:

os estudos clássicos de Geografia não deixam nunca de descrever o habitat e a vida rural e, entretanto, não dedicam, e raramente, mais do que algumas pobres linhas à alimentação. Lacuna incompreensível. Talvez porque aos geógrafos faltasse ainda um método capaz de orientá-los nesse domínio; perceberam o perigo de penetrar nos domínios dos folcloristas ou dos higienistas.

Nesse trabalho, Monbeig mostrou algumas fragilidades do método indutivo, na qual há pouco ou nenhum interesse em estudar a questão alimentícia da população. Analisando essas considerações sobre os aspectos teórico-metodológicos de Pierre Monbeig, colocamos a observação de Dantas (2002, p.76) a respeito do pensamento conjuntivo desse geógrafo:

É uma Geografia com determinações variadas, na qual os diversos elementos devem ser analisados e compreendidos no contexto de que fazem parte, o que quer dizer que um mesmo elemento pode influenciar a configuração espacial de forma diferenciada, a depender das circunstâncias em que se encontra e de onde se encontra.

Dessa maneira, Pierre Monbeig iniciou os estudos regionais no Brasil, por uma perspectiva positivista-funcionalista-culturalista, na qual o trabalho empírico era essencial para as análises da paisagem.

\section{Temas estudados por Pierre Monbeig}

Várias pesquisas desenvolvidas por Pierre Monbeig foram publicadas no Boletim Geográfico, mostrando os principais assuntos da produção científica do geógrafo francês. A maioria delas retrata a fase 
descritiva da geografia agrária brasileira, Monbeig (1944b, p.428), revelando a evolução da paisagem rural no Estado de São Paulo e considerando os aspectos físicos como moldadores da paisagem, mas também destacando a importância da imigração europeia para a modificação da paisagem do interior paulista:

Mas seria um erro querer a todo custo encontrar nos fenômenos atmosféricos a única explicação da paisagem rural atual. Apesar das frentes de povoamento paulista estarem em pleno desenvolvimento, apesar do observador notar muitas marcas de juventude, não se pode esquecer que este país jovem é explorado e, em parte, explorado há mais de quatro séculos.

Fica claro que o aspecto culturalista e a busca pelo entendimento das regiões culturais são uma marca na trajetória científica de Monbeig. Como característica acentuada dessa fase na geografia rural são as definições dos gêneros de vida e dos habitat rurais, Monbeig (1944b, p.429) mostra o modo de vida das populações no interior paulista:

para descrever os caipiras de São José dos Campos que só sabiam cultivar o solo pela enxada e pelo fogo, para produzir o pouco de milho, de arroz e de feijão necessário à sua subsistência. As reações psicológicas de nosso viajante têm o grande interesse de precisar os dois gêneros de vida tão fortemente opostos, um pelo seu nomadismo e pela pobreza de sua técnica agrícola, o outro, ao contrário, por sua vida sedentária e seu caráter semi-industrial.

Assim, Monbeig (1944b, p.430), a respeito do campo paulista, afirma que "as paisagens rurais atuais não revelam somente a revolução lenta e pacífica da agricultura e da sociedade rural; elas testemunham também uma melhor utilização dos solos", ou seja, a paisagem rural paulista não apresenta apenas a agricultura como base das atividades, mas sim uma transformação diferenciada do sul brasileiro com atividades semi-industriais. 
Monbeig (1945a, p.1878), numa análise da produção de cacau no espaço rural do sul da Bahia, faz uma caracterização do meio natural com o gênero de vida presente. $O$ autor deixa claro seu método empregado nessa pesquisa: "No estado atual de nossos conhecimentos, o trabalho do geógrafo baseia-se essencialmente no estudo regional: só o desenvolvimento de semelhantes estudos permitiu que abrandassem os velhos princípios do determinismo ratzeliano".

Monbeig (1945a, p.1878) diz que para desenvolver um estudo regional, não se deve fundamentar em apenas um aspecto, seja ele humano, seja natural. Deve-se ter um cuidado em não salientar uma característica, mas sim um entendimento de ambos:

Como o geógrafo parte de condições naturais, procura traçar um mapa de regiões naturais que não são precisamente unidades econômicas; e esse mapa não coincide com o dos gêneros de vida. Este exemplo é suficiente para mostrar a delicadeza com que todo geógrafo deve começar a delimitação da base territorial sobre a qual assentará o seu estudo, esforçando-se por não se restringir exclusivamente aos contornos geológicos, nem adotar uma zona econômica, nem ainda limitar-se a um agrupamento social.

Em outro estudo regional, Monbeig (1945b) viaja pelo norte paranaense relatando as características fisiográficas e humanas dessa região, descreve a frente pioneira que ocupou o território. No sentido de conhecer as diferentes regiões do Brasil, as zonas pioneiras são temas bastante pesquisados pelo autor.

Em um estudo acerca dos diferentes gêneros de vida rurais no Estado de São Paulo, Monbeig (1949, p.980) se esforçou para traçar uma classificação dos tipos de populações rurais. Nesse estudo regional da geografia humana, o autor dividiu em dois os grandes gêneros de vida no estado de São Paulo, o fazendeiro e o caboclo, sendo o primeiro o "grande proprietário que pratica a agricultura comercial introduzida pelos europeus nas regiões tropicais. O segundo é o desbravador indígena, isolado na floresta, com suas culturas à base de queimadas, deslocando-se continuamente". 
O artigo de Monbeig (1953) que trata da estrutura agrária no oeste paulista começa descrevendo as condições físicas dessa região; entretanto, no decorrer do trabalho, nota-se uma mudança no texto do autor. Antes, os trabalhos eram detalhados com relação à descrição das paisagens e com os aspectos de habitat, nesse artigo, o autor toca em assuntos como a condição jurídica da terra, migrações, estrutura fundiária e fragmentação das terras "A condição jurídica das terras, num Brasil que havia sido domínio português, trazia sérios obstáculos à colonização pioneira" (ibidem, p.457). O conceito de paisagem é bastante utilizado pelo autor, indicando o local habitado e com as transformações realizadas pelo homem: "A estrutura social do mundo pioneiro está impressa na paisagem: muito cheia de contrastes, é mais bem compreendida no terreno, o que não se dá nos campos muito alongados do nosso país. Contrasta a zona de sítios com a de fazendas" (ibidem, p.465).

O caráter metodológico do autor, todavia, centra-se na observação e no método indutivo. A descrição continua sendo a principal ferramenta de Monbeig, mas nesse texto, ele insere temas antes não abordados em sua produção científica. Ele deixa claro, contudo, que uma análise mais aprofundada da situação da paisagem dessa frente pioneira somente seria possível por meio de um inquérito mais apurado.

Monbeig (1957) analisa as tendências da agricultura paulista, além de verificar os impactos do êxodo rural e suas consequências para a atividade agrícola. $\mathrm{O}$ autor analisa a economia cafeeira no Brasil ao longo de sua trajetória dos séculos XIX e XX, com análises estatísticas da produção, além de caracterizar os aspectos sociais e econômicos, situando no contexto do mundo atual:

A geografia econômica do café reflete perfeitamente o mundo atual: dela apreendemos aquilo que subsiste ainda de uma época em que os grandes países industrializados do hemisfério norte dominavam as economias e exploravam os recursos dos países tropicais. Mas, ao mesmo tempo, esta geografia permite medir os esforços dos países subdesenvolvidos para se libertarem ao preço de mil dificuldades. (Monbeig, 1954, p.285) 
Analisando a produção de Monbeig, podemos fazer um esquema (Organograma 2) a respeito da abordagem e perspectivas teóricometodológicas da geografia francesa e suas influências na geografia agrária brasileira.

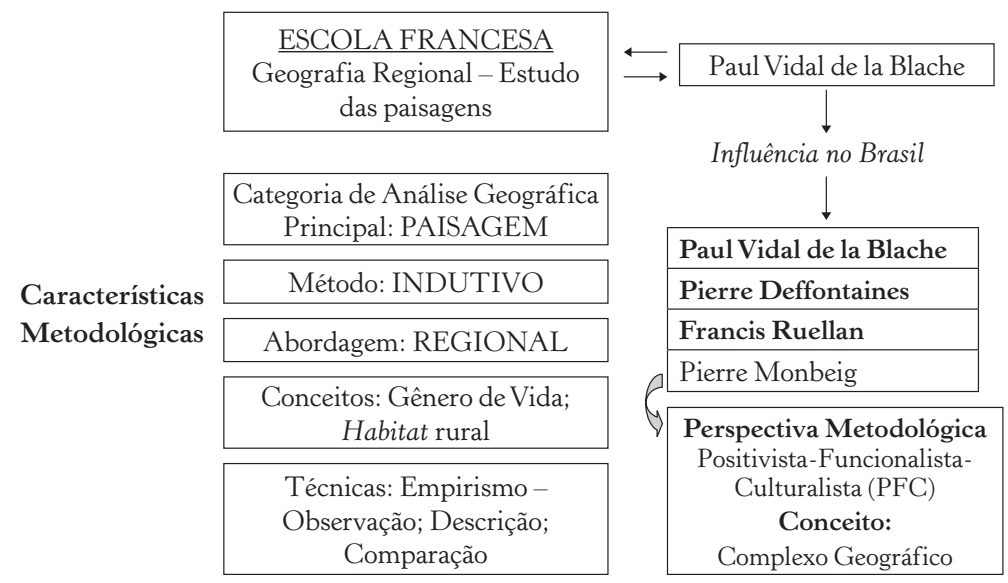

Organograma 2 - Abordagem teórico-metodológica da geografia francesa (Organizado pelo autor do texto).

Os conceitos enfatizados na geografia agrária clássica estavam relacionados com as organizações rurais, como habitat, gêneros e modos de vida, tipos de povoamento e sistema agrícola. As influências teóricas e metodológicas francesas e alemãs embasaram as pesquisas no Brasil, por isso o predomínio dos estudos regionais originários de Paul Vidal de La Blache que se difundiram com Pierre Monbeig ou os estudos das paisagens agrárias (econômicas e culturais) de Leo Waibel, que foi o grande mestre de Orlando Valverde.

\section{Leo Waibel: a geografia alemã nos estudos rurais brasileiros}

Em relação às influências exercidas e ao referencial deixado na geografia agrária brasileira, a escola alemã teve menor impacto na 
construção do pensamento geográfico comparada à escola francesa. Entretanto, o geógrafo Leo Heinrich Waibel (Foto 2), nascido no dia 22 de fevereiro de 1888, vindo a falecer em 4 de setembro de 1951, durante seu período no Brasil, de 1946 a 1950, desenvolveu diversas pesquisas a cargo do Conselho Nacional de Geografia. Especialmente, acerca da colonização e do uso da terra pela agricultura em áreas de expansão, consideradas vazias em termos populacionais, como as regiões Sul, Centro-Oeste e Norte.

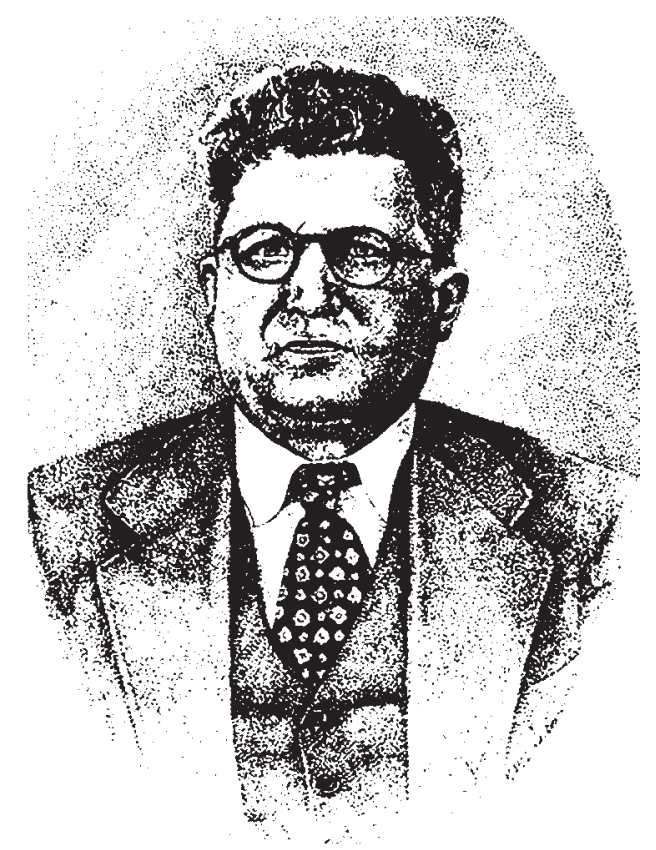

Foto 2 - Leo Waibel

Fonte: Bernardes (1952, p.201).

Sua produção bibliográfica no Brasil é dispersa em vários artigos publicados na Revista Brasileira de Geografia e no Boletim Geográfico, além dos livros A colonização dos campos do Estado do Paraná (de 1949) e Capitulos de Geografia Tropical e do Brasil (de 1958), entre muitas obras publicadas na Alemanha no período de 1912 a 1942. 
As bases teórico-metodológicas que balizaram as pesquisas de Leo Waibel sem dúvida passaram pelos ensinamentos do geógrafo Alfred Hettner, ou seja, o entendimento da paisagem cultural e as formações econômicas das paisagens. Para Etges (2000a, p.15), Waibel desenvolveu quatro conceitos-chave em sua obra "Paisagem cultural", "Formação econômica", "Colonização" e "Uso da terra".

De forma resumida, a obra de Hettner se concentra em mostrar que o cerne metodológico da geografia é a abordagem corológica, ou seja, explicar e descrever as características diferenciadas da superfície terrestre; para isso, as noções básicas da pesquisa para ele concentram-se em "observação de campo, o aprofundamento teórico, através de leituras sistematizadas, coleta e sistematização de dados coletados, objetivando a generalização" (ibidem, p.25).

Leo Waibel, sob essa influência hetteneriana, inseriu novas técnicas e teorias no estudo da geografia agrária, entre elas a dos economistas; nesse caso, a Teoria da Localização Agrícola de Von Thünen, e em seu livro publicado em 1933, Problemas da geografia agrária desenvolveu essa metodologia de análise. Posteriormente, em 1938, aplicou o modelo thuniano para explicar a organização dos produtos agrícolas nas regiões tropicais, em destaque a Guatemala e a Costa Rica. Waibel conseguiu trazer para a geografia os fundamentos teórico-metodológicos do modelo espacial e locacional, essencialmente para os espaços agrários:

O "Estado Isolado" de Thünen demonstra ser a chave da geografia agrária. Ele nos possibilita discernir entre as causas intrínsecas inerentes à economia e atuantes na organização agrogeográfica da Terra $e$ as causas referentes as condições naturais. O forte contraste entre as forças endógenas e exógenas torna-se claro na geografia econômica, e somos levados a tentar elucidar a sua influência na individualização das paisagens econômicas da Terra. (Waibel, 1955b, p.294)

Em seu trabalho sobre as áreas de produção agrícola e pecuária na Costa Rica, Waibel (1948) utilizou o modelo do Estado Isolado de Von Thünen como ferramenta metodológica para entender a 
organização das populações, levando em consideração os aspectos naturais, atividades agropecuárias e o distanciamento das cidades.

Com influências de Alfred Hettner (sua base principal), Ritter e Ratzel com menos ênfase, sua base metodológica aponta para uma classificação das diferentes paisagens agrárias considerando os dados Estatísticos, Ecológicos e Fisionômicos. Esses elementos determinam uma paisagem agrária (Figura 1), o que entendemos hoje de espaço rural. Esse assunto é lembrado por Etges (2000a, p.51):

Waibel, sem sombra de dúvida, percorreu a mesma trajetória dos geógrafos que se queriam fazer respeitar como cientista na época: começa nas ciências naturais, estudando o mundo das plantas e dos animais, na tradição de Humboldt, para num segundo momento, tomar consciência da importância do papel da História e do homem, consequentemente, na configuração das paisagens, na tradição de Ritter. Introduziu o econômico nas suas análises (Wirtschaftsformation) e passou a analisar as paisagens como paisagens culturais, na tradição de Schlüter e Hettner.

\section{Concepção da categoria de análise de Leo Waibel}

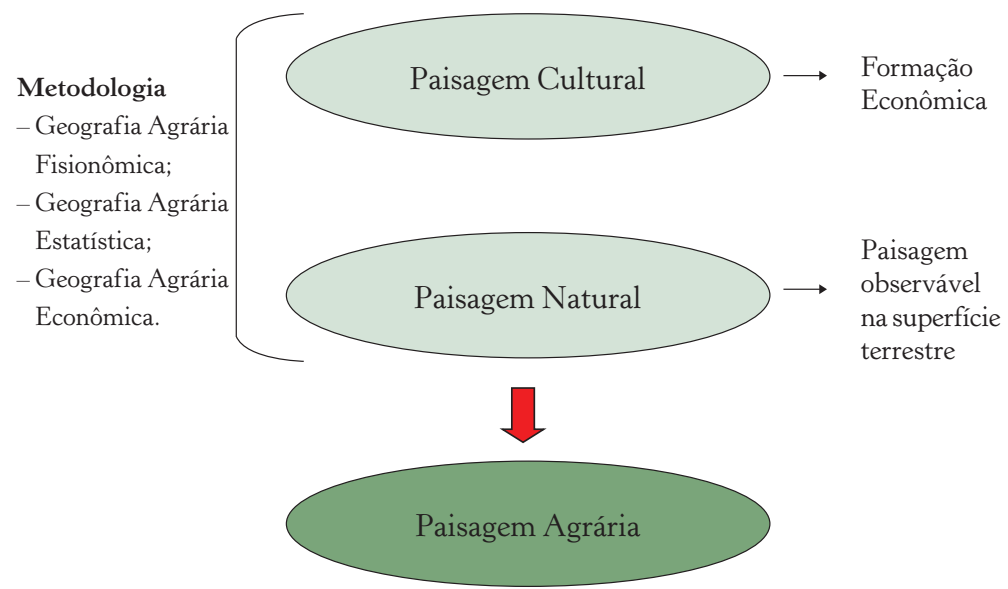

Figura 1 - A categoria Paisagem Agrária na obra de Leo Waibel (Alves \& Maia, 2009, p.57) 
Waibel (2000b, p.40) teve muita influência da geografia econômica no desenvolvimento de seus estudos da paisagem agrária, desprendendo-se do determinismo alemão que considerava e valorizava os aspectos físicos sobre o homem:

Waibel passou a orientar-se para análises sistemáticas no campo da Geografia Econômica, especialmente no que dizia respeito ao espaço agrário. Nas discussões referentes à Geografia da Paisagem (Landschaftskunde) Waibel deu a sua contribuição quando passou a destacar o papel dos homens na formação da paisagem cultural, conceito este que tem sua origem nas pesquisas sobre a paisagem do início do século XX, expressando a influência dos homens na formação e transformação da superfície terrestre.

Apesar de tratar da paisagem natural em suas investigações, certamente a paisagem cultural e a formação econômica foram dois conceitos-chave no referencial de Leo Waibel, por isso ele considerou a geografia agrária um ramo da geografia econômica:

a compreensão que Waibel tinha da Geografia Agrária, entendendo-a como um ramo da Geografia Econômica, o que se expressava na preocupação em caracterizar os diferentes espaços agrários a partir de parâmetros previamente estabelecidos, no caso, a concepção econômica. (Etges, 2000a, p.107)

Schneider (2002, p.40) trata o conceito de paisagem cultural utilizado por Waibel como uma possibilidade nos estudos e reflexões na inter-relação entre o espaço rural e urbano:

parece sugestivo o conceito de paisagem cultural, que poderá constituir-se em ferramenta analítica interessante para auxiliar na reflexão acerca das inter-relações espaciais entre o rural e o urbano, cujas fronteiras são cada vez mais difíceis de serem delimitadas. A superação desta dicotomia, de corte setorial (do tipo agrícola versus indústria) e não raramente embebida de conteúdo ideológico (no sentido de comparar o atrasado versus o moderno), poderá ser o primeiro 
passo para se pensar a dinâmica socioespacial do meio rural em sentido mais amplo que aquele relacionado aos atributos produtivos e comerciais das atividades econômicas que ali são predominantes.

Ao discorrer sobre a importância de alguns geógrafos que trabalham com as transformações no espaço geográfico decorrentes da modernização, Verdum (2005, p.92) menciona a contribuição de Leo Waibel: "através da abordagem considerada como sendo a da paisagem cultural, esses geógrafos são, na sua maioria, testemunhas vivas das opções de desenvolvimento rural brasileiro e das degradações ambientais".

Dessa forma, o papel desempenhado por Waibel foi de significativa importância para a geografia agrária, superando o determinismo geográfico, associando o cultural na formação da paisagem agrária - a paisagem cultural. Conceito esse que pode ser utilizado proficuamente nos estudos sobre a relação cidade campo, conforme referido por Schneider (2002), uma vez que Waibel vai introduzir na análise espacial (Organograma 3), além das análises da forma e função contidas nos modelos de Von Thünen, a questão da estrutura sociocultural influenciando esse espaço específico.

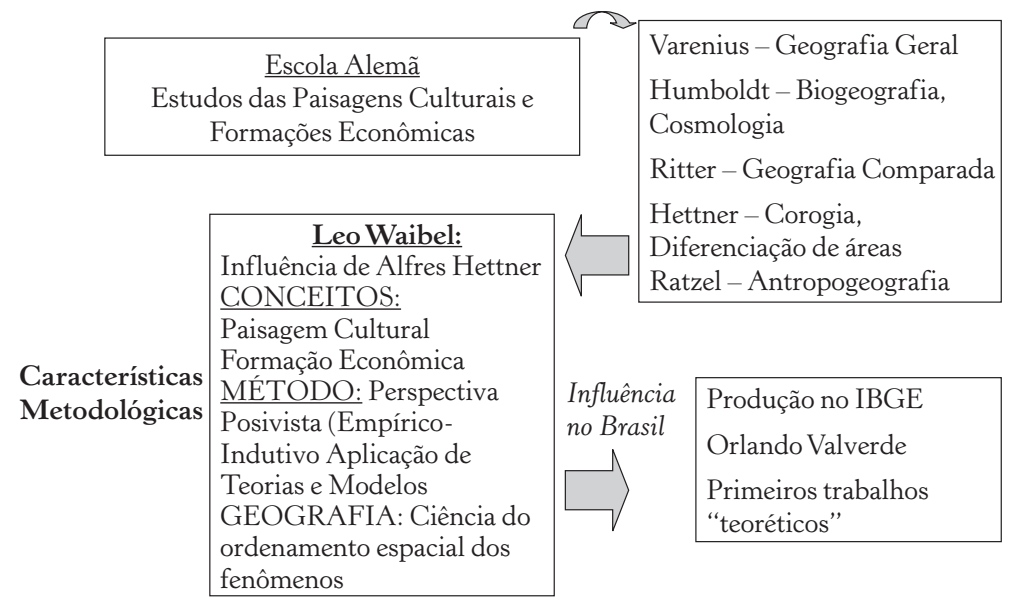

Organograma 3 - Abordagem teórico-metodológica da geografia alemã e de Leo Waibel (Organizado pelo autor do texto). 
As influências deixadas por Leo Waibel para a geografia agrária brasileira passam, sem dúvida, nos trabalhos desenvolvidos no IBGE, e na formação de pesquisadores nesse instituto, entre eles se destaca Orlando Valverde, que seguiu a linha metodológica de Waibel. A utilização de teorias e modelos foram inovações no campo da geografia agrária; Leo Waibel, ao usar Von Thünen, fugiu das simples observações e descrições das paisagens; ele fazia essa descrição, entretanto, correlacionava as paisagens naturais com as culturais com uma ligação histórica, para assim identificar e classificar as diferentes áreas.

O acréscimo teórico-metodológico da obra de Waibel surge em 1923, quando ocupa a cátedra no Instituo de Kiel, onde desenvolve diversos trabalhos de geografia econômica, especificamente a geografia agrícola. Entretanto, as viagens de campo foram de suma importância para o enriquecimento do conhecimento geográfico aplicado de Waibel (Quadro 1),

Quadro 1 - Viagens científicas de Leo Waibel

\begin{tabular}{|l|l|}
\hline \multicolumn{1}{|c|}{ Período } & \multicolumn{1}{c|}{ Destino } \\
\hline $1911-1912$ & Camarões \\
\hline 1914 & Sudoeste Africano (Colônias alemãs) \\
\hline $1925-1926$ & México e Estados Unidos \\
\hline 1937 & América Central \\
\hline 1939 & Estados Unidos \\
\hline $1946-1950$ & Brasil \\
\hline
\end{tabular}

Fonte: Bernardes (1952) (Organizado pelo autor do texto).

O período de cinco anos que ficou no Brasil é considerado o mais profícuo da carreira cientifica de Waibel. Foi nas área de colonização e de expansão da agricultura que ele, juntamente com outros geógrafos do IBGE, Fábio de Macedo Soares Guimarães, Orlando Valverde, Walter Alberto Egler, Nilo Bernardes e Speridião Faissol, desenvolveram as pesquisas sobre as novas áreas ocupadas no território nacional, sob a política governamental do Estado Novo de Getulio Vargas (Almeida, 2003). 


\section{Temas estudados por Leo Waibel}

Durante sua vida acadêmica e profissional, Waibel preferiu trabalhar com temáticas relacionadas com a agricultura e as populações rurais. Dessa maneira, os conceitos enfatizados na geografia agrária clássica remetiam-se às organizações rurais, como habitat, gêneros e modos de vida, tipos de povoamento e sistema agrícola. Os estudos regionais para conhecer novas áreas a partir da colonização formaram boa parte dos trabalhos de Waibel.

A metodologia de Waibel era calcada na análise da Geografia Agrária Estatística, Fisionômica e Ecológica com a aplicação de teorias e modelos espaciais, especialmente a Teoria da Localização da Produção Agrícola.

Waibel (1947a) retratou a economia agrícola da região dos trópicos, fazendo uma caracterização geral da produção e a relação com as condições climáticas e a industrialização, para tal, analisou os países asiáticos, africanos e latino-americanos. A ideia dessas pesquisas era "desvendar" as diferentes regiões, ou seja, conhecer os diferentes modos de vida e como se organizavam. Assim, Waibel (1948a) trabalhou com a Teoria do Estado Isolado de Von Thünen na espacialização das culturas agrícolas na Costa Rica (Figura 2).

Esse estudo deu início a outras metodologias para a geografia agrária, enfocando o caráter espacial e ao mesmo tempo relacionando-o com os elementos econômicos, que são importantes para a agricultura e as populações rurais. Dessa forma, a geografia agrária deixa de ser meramente descritiva e passa a ser um ramo conexo com a geografia econômica, industrial, do comércio, assim fazendo interrelações com elementos que interferem na economia de determinada localidade.

Esse modelo aplicado por Waibel na Costa Rica, entretanto, não é estático e isolado como o modelo proposto por Thünen; as dinâmicas da região, população e o relevo acidentado não permitem compor anéis concêntricos. Mas a base teórica e metodológica serve como parâmetro desse novo estudo regional. 


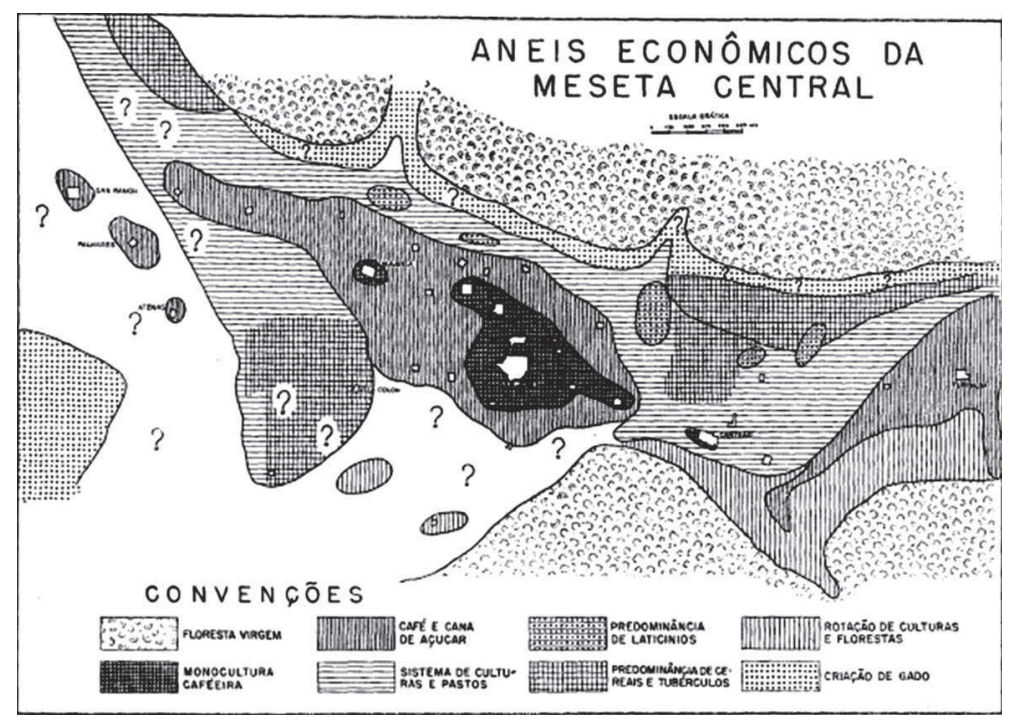

Figura 2 - Uso da Teoria de Von Thünen na região central da Costa Rica (Waibel, 1948a, p.20).

A respeito da Teoria do Estado Isolado de Von Thünen na geografia agrária, Leo Waibel (1955b, p.277) tece algumas considerações sobre o método e a aplicabilidade da teoria. Primeiramente, ele discute sobre a qual filosofia pertence o método de Thünen:

Indiscutivelmente, a favor do método indutivo depõe, em todo caso, a preferência de Thünen pelo emprego dos métodos matemático-algébricos, que se tornam para ele uma verdadeira paixão, sendo empregados inclusive onde não são necessários. Isto dificulta sobremaneira a leitura de sua obra e em parte é uma das causas que contribuíram para a sua pouca divulgação. Dedutiva é também a sua concepção da abstração, que ele manuseia com grande virtuosidade e que lembra inteiramente o processo de trabalho do pesquisador experimental em ciências naturais. [...] O fundamental no método de Thünen é, portanto, que ele pesquisou e raciocinou tanto de modo dedutivo como indutivo. 
Como bases teóricas de Leo Waibel, destacam-se Carl Ritter e Alfred Hettner, delineando um pensamento naturalista da formação da paisagem. Todavia, pela teoria de Von Thünen, Waibel conseguiu trazer para a geografia os fundamentos teórico-metodológicos do modelo espacial e locacional, essencialmente para os espaços agrários:

O "Estado Isolado" de Thünen demonstra ser a chave da geografia agrária. Ele nos possibilita discernir entre as causas intrínsecas inerentes à economia e atuantes na organização agrogeográfica da Terra $e$ as causas referentes às condições naturais. $O$ forte contraste entre as forças endógenas e exógenas torna-se claro na geografia econômica, e somos levados a tentar elucidar a sua influência na individualização das paisagens econômicas da Terra. (ibidem, p.294)

O sul de Goiás foi estudado em sua pesquisa publicada em 1947; nessa região, Waibel (1947b) mostrou como as colônias agrícolas viviam e produziam, além de caracterizar o tamanho das propriedades e as origens da população residente, ou seja, uma pesquisa que visava conhecer o imenso território brasileiro, pela caracterização das áreas de colonização. A respeito da colonização europeia no sul brasileiro, Waibel (1949, p.160) faz uma síntese das viagens realizadas nos três Estados que compõem essa região. Primeiramente, ele deixa clara a forma de entender a paisagem geográfica:

O nosso modo de encarar o problema da colonização será do ponto de vista geográfico, salientando as relações entre a terra de um lado e as atividades do colono de outro. A paisagem cultural criada pelo colono é o nosso tema principal. Os outros aspectos da colonização, tais como a história e as condições jurídicas, religiosas, sociais e políticas, serão mencionados somente na medida que estiverem relacionados com a paisagem cultural.

Nesse trabalho, Waibel descreve as condições naturais da região, explicando como éa base física que dá suporte aos sistemas agrícolas 
ali existentes. Mostra também os tipos de colonizações e as origens dos imigrantes (alemães, italianos e eslavos). Essa combinação entre colonização e sistema agrícola está diretamente relacionada à construção da paisagem cultural, pois o tipo de atividade agrícola desenvolvida representa uma parte dessa paisagem:

Depois do tipo de colonização, é o sistema agrícola adotado pelos colonos o fato de maior significado para a colonização. Estas coisas são, muitas vezes, consideradas como evidentes por si próprias e de pouco interesse científico. Contudo, os sistemas agrícolas são na realidade muito complicados e envolvem muitos problemas. Constituem os objetos de duas ciências que parecem mal conhecidas no Brasil, a economia agrícola e a geografia agrícola. (ibidem, $\mathrm{p}$. 180)

Waibel (1949) distingue três tipos de sistemas agrícolas, os quais entende como um processo evolutivo da paisagem cultural, 1) sistema da primitiva rotação de terras; 2 ) sistema de rotação de terras melhorada e 3) rotação de culturas combinadas com a criação de gado. Com relação aos tipos de povoamento, o autor descreve os habitats rurais e os núcleos de população, e na visão dele os imigrantes devem morar em núcleos homogêneos, não havendo muito contato com os "luso-brasileiros"; essa ideia proposta pelo alemão Leo Waibel não confere com os ideais nacionalistas do governo brasileiro de formar uma nação. Os núcleos "fechados" de colonos mantinham pouco contato com os brasileiros, além de manter a língua do país de origem.

Waibel (1954, p.370) pesquisou uma das formas de ocupação do espaço agrícola nas regiões tropicais, o "Plantage", sendo um local de atividade intensa e de monocultura. Conforme as bases teóricas de Waibel, o autor considera paisagem como a categoria da análise na geografia agrária, e sobre estes temas ele afirma:

Este contraste fisionômico da paisagem entre os estabelecimentos nativos e os estabelecimentos do tipo "plantage", até as primiti- 
vas condições de vida da população nativa sofreram fundamentais transformações na sua estrutura social, econômica e política por influência dos europeus.

Waibel (1954, p.376) define o "Plantage" da seguinte forma: "uma 'plantage' é um grande estabelecimento agroindustrial, que via de regra, sob direção de europeus produz, com grande emprego de trabalho e de capital, produtos agrícolas valorizados para o mercado mundial". Assim, o autor considera esse tipo de cultura agrícola voltada para o mercado externo, alterando a paisagem cultural típica das regiões tropicais, nesse aspecto teórico. Waibel (1955a) verifica essa produção de "plantage" nas zonas tropicais com as áreas de colonização realizadas pelos europeus, analisando a questão do abastecimento do mercado europeu.

Waibel (1955c) estudou as "zonas pioneiras" criadas pela expansão da agricultura no Brasil, analisando os principais impactos decorrentes da criação dos novos povoamentos na paisagem agrária e urbana. Destacando as zonas pioneiras desde o século XVIII, com a cultura do algodão no Maranhão, e posteriormente, no século XIX, o desenvolvimento da cultura do café sendo o principal produto para a criação dessas zonas pioneiras no Brasil central, em especial o Estado de São Paulo. Além dessas regiões, o sul do Brasil também teve suas zonas pioneiras nesse mesmo século, com as colônias de imigrantes europeus. No século XX, as zonas pioneiras destacadas por Waibel (1955c) concentram-se no Centro-Oeste, e na região Sul, mais ao norte do Paraná com o desenvolvimento do café, e a oeste da região Sul. Após essas constatações realizadas por trabalhos de campo, Waibel (1955c) faz algumas comparações entre as zonas pioneiras e a agricultura no Brasil e dos Estados Unidos.

Apesar de sua breve passagem pelo Brasil, Waibel conseguiu estudar e caracterizar diferentes regiões, ainda pouco conhecidas, especialmente os assuntos ligados a agricultura, população e economia. Além de inserir na geografia agrária novas formas de pesquisar ao aplicar teorias econômicas nos procedimentos metodológicos e fazer análises com uma gama de variáveis. 


\section{Considerações finais}

Ao resgatar a história da geografia agrária, buscou-se analisar alguns autores e escolas que deram sua contribuição à pesquisa geográfica sobre as questões ligadas ao rural e os legados deixados para a epistemologia da geografia.

Os pressupostos teórico-metodológicos da escola francesa tiveram maior influência na geografia brasileira, bem como nos estudos rurais, com a herança deixada por essa vertente teórica na figura maior de Pierre Monbeig e na formação de diversos pesquisadores e linhas de pesquisas sobre a geografia regional.

Assim, o estudo regional foi, sem dúvida, a grande herança deixada pelos geógrafos franceses que passaram pelo Brasil, que formaram o lastro da geografia brasileira.

Em paralelo, a geografia alemã, por sua vez, analisada na figura de Leo Waibel, destaca-se pela influência deixada no IBGE e nos pesquisadores que trabalharam nessa época.

Como a formação dos cursos universitários no Brasil se deu pela vinda dos geógrafos franceses, o referencial teórico alemão não teve o mesmo grau de aplicabilidade no início da geografia universitária no Brasil. Por causa do convite do IBGE para que alguns geógrafos alemães exercessem pesquisas no Brasil, foi nesse momento que houve uma maior integração dessa base teórico-metodológica. Os elementos econômicos e culturais da paisagem remetem a um avanço das descrições da paisagem, além da contribuição estatística e modelística para o entendimento da organização do espaço, dando os primeiros indícios de uma geografia teorética.

\section{Referências}

AB'SÁBER, A. N. Pierre Monbeig: a herança intelectual de um geógrafo. Estudos Avançados, São Paulo, v.8, n.22, p.221-32, 1994.

ALMEIDA, R. S. de. A geografia do IBGE: um esboço histórico. Revista do Instituto Histórico e Geográfico Brasileiro, v.164, n.418, p.79-99, 2003. 
ALVES, F. D. A influência alemã e francesa na geografia agrária brasileira. In: IX SEMINÁRIO DE PÓS-GRADUAÇÃO EM GEOGRAFIA DA UNESP. Rio Claro. Anais... Rio Claro: Ageteo, 2009, p.2000-16.

ALVES, F. D.; FERREIRA, E. R. Elementos metodológicos da geografia agrária clássica: a produção em periódicos brasileiros. GeoUERJ, Rio de Janeiro, v.2, n.18, p.43-61, 2008.

ALVES, F. D.; MAIA, A. C. Teorias sobre o espaço e a questão ruralurbano. In: FERREIRA, D. A. O; FERREIRA, E. R. Estudos agrários: conceitos e práticas. Rio Claro: IGCE/Unesp - Pós-Graduação Geografia, 2009. p.47-64.

ANDRADE, M. C. de. A construção da geografia brasileira. Finisterra, v.XXXIV, n.67-8, p.21-30, 1999.

BERNARDES, N. Leo Waibel. Revista Brasileira de Geografia, v.14, n.2, p.199-201, 1952.

BRAY, S. C. Considerações sobre o método de interpretação funcionalista na geografia. Boletim de Geografia Teorética, v.10, n.20, p.33-43, 1980.

. Pierre Monbeig, o patriarca da geografia paulista e nacional. Geografia, v.12, n.24, p.119-20, 1987.

- A geografia acadêmica tradicional no Brasil: positivismo com historicismo? In: I COLÓQUIO BRASILEIRO DE HISTÓRIA DO PENSAMENTO GEOGRÁFICO. Anais... Uberlândia, 2008, p.1-8.

DANTAS, A. Monbeig: paisagem e geografia estigmática. Mercator, v.1, n.2, p.71-8, 2002.

Pierre Monbeig: um marco da geografia brasileira. Porto Alegre: Sulina, 2005.

ETGES, V. E. Geografia Agrária: a contribuição de Leo Waibel. Santa Cruz do Sul: Edunisc, 2000a.

A paisagem agrária na obra de Leo Waibel. GEOgraphia, Niterói, ano 2, n. 4, p.27-47, 2000b.

MONBEIG, P. Ensaios de geografia humana brasileira. São Paulo: Livraria Martins, 1940.

Estudos geográficos. Boletim Geográfico, v.1, n.11, p.7-11, 1944a. . Notas relativas à evolução das paisagens rurais no Estado de São Paulo. Boletim Geográfico, v.2, n.16, p.428-30, 1944 b.

Os problemas geográficos do cacau no sul do Estado da Bahia. Boletim Geográfico, v.2, n.24, p.1878-83, 1945a.

. A zona pioneira do Norte-Paraná. Boletim Geográfico, v.3, n.25, p.11-17, 1945b.

A Geografia no ensino secundário. Boletim Geográfico, v.3, n.26, p.163-71, 1945c. 

1945d.

Pesquisas Geográficas. Boletim Geográfico, v.3, n.31, p.915-19,

. A geografia e o meio vivo. Boletim Geográfico, v.3, n.34, p.1267-9, 1946.

. Evolução de gêneros de vida rurais tradicionais no sudeste do Brasil. Boletim Geográfico, v.7, n.81, p.980-7, 1949.

As estruturas agrárias da faixa pioneira paulista. Boletim Geográfico, v.11, n.116, p.455-65, 1953.

Resumo da geografia econômica do café. Boletim Geográfico, v.12, n.122, p.276-87, 1954.

As tendências atuais da agricultura no Estado de São Paulo. Boletim Geográfico, v.15, n.141, p.721-6, 1957.

SCHNEIDER, S. A atualidade da contribuição Leo Waibel ao estudo da agricultura familiar. Boletim Gaúcho de Geografia, v. 28, n. 1, p.25-41, 2002.

VERDUM, R. Os geógrafos frente às dinâmicas sócio-ambientais no Brasil. Revista do Departamento de Geografia, São Paulo, n.16, p.91-4, 2005.

WAIBEL, L. O sistema das plantações tropicais. Boletim Geográfico, v.5, n. 56, p.896-900, 1947a.

Uma viagem de reconhecimento ao sul de Goiás. Revista Brasileira de Geografia, v.9, n.3, p.313-42, 1947 b.

. A teoria de Von Thünen sobre a influência da distância do mercado relativamente a utilização da terra. Revista Brasileira de Geografia, v.10, n.1, p.3-40, 1948a.

. Vegetação e o uso da terra no Planalto Central. Revista Brasileira de Geografia, v.10, n.3, p.335-80, 1948b.

Princípios de colonização européia no Sul do Brasil. Revista Brasileira de Geografia, v.11, n.2, p.159-222, 1949.

. A forma econômica da "Plantage" tropical. Boletim Geográfico, v.12, n.123, p.369-83, 1954.

O abastecimento da zona temperada com produtos agrícolas tropicais. Boletim Geográfico, v.13, n.125, p.143-54, 1955a.

A lei de Thünen e a sua significação para a geografia agrária. Boletim Geográfico, v.13, n.126, p.273-94, 1955 b.

As Zonas Pioneiras do Brasil. Revista Brasileira de Geografia, v.17, n.4, p.398-422, 1955c.

. Capítulos de Geografia Tropical e do Brasil. Rio de Janeiro: IBGE, 1958.

Determinismo geográfico e geopolítica. Boletim Geográfico, n.19, v.164, p.612-17, 1961. 



\section{2 \\ As DUAS NOVAS LEITURAS \\ DO HOMEM-CARANGUEJO DE Josué de CASTRO}

Bruno Picchi*

\section{Introdução}

Geógrafo e médico, Josué de Castro nasceu na cidade do Recife, capital do Estado de Pernambuco, no dia 5 de setembro de 1908. Com apenas 21 anos concluiu o Curso Superior em Medicina pela Faculdade de Medicina do Rio de Janeiro. Três anos depois, em 1932, tornou-se livre-docente em Fisiologia pela Faculdade de Medicina de Recife com a tese O problema fisiológico da alimentação no Brasil, trabalho que já indica a importância atribuída pelo autor ao campo da nutrição, o que caracterizará toda sua obra (Amancio Alves, 2007).

Em 1935. mudou-se para o Rio de Janeiro, assumindo a cátedra de Antropologia da antiga Universidade do Distrito Federal e, em 1940, tornou-se professor catedrático de Geografia Humana na Faculdade Nacional de Filosofia da Universidade do Brasil. Nesse período, publicou A alimentação brasileira à luz da geografia humana em 1937, sendo essa publicação a primeira em que Josué de Castro se posiciona claramente em favor do "método geográfico" (ibidem). Em 1946, publicou Geografia da fome, uma de suas obras mais conhecidas e elogiadas.

* Mestre em Geografia pela Unesp, campus de Rio Claro. 
Em decorrência do golpe militar de 1964, que depôs o presidente João Goulart, eleito democraticamente, os militares cassaram os direito políticos de Josué de Castro, eleito deputado federal em 1954. No dia 24 de setembro de 1973, exilado na França, faleceu precocemente aos 65 anos. Uma semana antes, havia pedido mais uma vez o seu direito ao passaporte brasileiro, que lhe fora negado. Voltou morto, tendo sido enterrado no Rio de Janeiro, ainda censurado e vigiado (Marchi, 1998, p.17-18).

O possibilismo de Jean Brunhes e Vidal de La Blache, mais profundamente divulgados no Brasil a partir dos anos 1930, com a vinda dos geógrafos franceses, influencia fortemente a obra de Josué de Castro. O autor fez referência direta a essa influência em seus trabalhos e demonstrou sua filiação a essa corrente ao aceitar a conjugação de diferentes fatores - étnicos, econômicos, históricos, naturais - na sua análise da realidade, voltada, antes de tudo, para os problemas sociais e econômicos causadores da fome (ibidem, p.ii).

Defendia que, ao estudar cientificamente o fenômeno da fome, diante da vastidão do problema, era necessária uma abordagem multidisciplinar:

Assim, sendo este um problema de tão grande interesse vital paras nações, para que se obtenha um profícuo conhecimento de sua essência é necessário recorrer-se aos princípios científicos de múltiplas disciplinas. Para ser estabelecida uma alimentação racional fundada sobre princípios rigorosamente científicos, alimentação que constitui a necessidade mais premente da vida e condição essencial para uma eficaz atividade produtiva de um povo, numa determinada região, são precisos, de um lado, estudos aprofundados da fisiologia da nutrição, dos caracteres físicos e morais do povo dessa região, de sua evolução demográfica, de sua capacidade e resistência orgânicas e de outro lado, estudo das condições físicas do meio, das suas condições econômicas, da organização social e dos gêneros de vida dos seus habitantes. Abarca, assim, o estudo da alimentação, capítulos de biologia, de antropologia, física e cultural, de etnogeografia, biologia, de patologia, de sociologia, de economia política e mesmo de história. (Castro, 1937, p.22) 
Diante de tal complexidade, julga que o único método eficaz de análise sobre a questão seria o método geográfico:

Não o método puramente descritivo da antiga geografia, velha como o mundo, mas o método da ciência geográfica que é nova, que é quase dos nossos dias. Que se corporificou dentro dos princípios científicos formulados pelas experiências de geógrafos como Karl Ritter, Humboldt, Ratzel e Vidal de La Blache. (ibidem, p.24-5)

A base da definição de método de Josué de Castro está nos quatro "princípios geográficos" que podem ser notados em toda sua obra:

Só a Geografia, que considera a Terra como um todo, e que ensina a saber ver os fenômenos que se passam em sua superfície, a observá-los, agrupá-los e classificá-los, tendo em vista a sua localização, extensão, coordenação e causalidade, - pode orientar o espírito humano na análise do vasto problema da alimentação, como um fenômeno ligado, através de influências recíprocas, à ação do homem, do solo, do clima, da vegetação e do horizonte de trabalho. (ibidem, p.25-6)

Em 1948, publicou a sua defesa da cátedra de Geografia Humana na Universidade do Brasil, intitulada Fatores da localização da cidade do Recife, trabalho muito influenciado pelo geógrafo francês Maximilien Sorre (1880-1962), em relação à proposição da análise mais voltada à ecologia, uma contribuição fundamental para novos direcionamentos, considerando que Josué destacou os princípios geográficos clássicos, como a influência da história, cultura e economia (Campos, 2004, p.173).

Sua obra é uma constante tanto para as ciências humanas, em relação à utilização do método geográfico no estudo da fome e na reflexão sociológica desse fenômeno, quanto para as ciências biológicas, pela investigação das causas por de trás das doenças ligadas ao déficit nutricional e os problemas fisiológicos da alimentação no Brasil.

O pensamento de Josué de Castro é o objeto de estudo deste trabalho, tendo no prefácio de seu romance de 1967 Homens e caranguejos 
(Castro, 2007) a origem da metáfora proposta por Melo Filho (2003) acerca desse outro tipo de homem, o homem-caranguejo.

A evolução desse "novo ser" ao longo do século passado fez que duas novas leituras, ambas na década de 1990, emergissem diante das mudanças de ordem econômica e social no mundo contemporâneo: na primeira, esse homem-caranguejo é expulso de sua moradia, ganha o asfalto e é descoberto pela mídia, causando comoção nacional, pois a pobreza o transformou em um homem-rato, o homem-gabiru; na segunda, é utilizado o mesmo mangue para se conectar ao mundo, via o símbolo de uma antena parabólica incrustada na lama de seus manguezais capaz de captar as novas influências e ritmos de um mundo globalizado. Denominados caranguejos-com-cérebro, esse grupo de artistas pernambucanos cria uma estética cultural inovadora, híbrida, reafirmando a existência desta teimosa criatura que insiste em sobreviver: o homem-caranguejo.

\section{Homem-caranguejo}

A relação inicial entre Josué e o fenômeno da fome já está implícita em seu nascimento, pois ao nascer em Recife explicita-se a relação com a tristemente famosa seca de 1877, que expulsou os avós maternos e seu próprio pai do sítio que possuíam em Cabaceiras, no sertão paraibano. É nessa seca de proporções espantosas que se encontra a origem de um fenômeno familiar aos brasileiros, tão difundido nessas regiões do semiárido nordestino: a indústria da seca. O imperador D. Pedro II enviou às áreas atingidas uma comissão técnica composta unicamente por engenheiros, visando à remediação exclusivamente por meio de obras de engenharia, "a colocação do problema como natural, e não de ordem sociopolítica, colaborou com a permanência das causas - e também para que estas se agravassem - e permitiu o surgimento da indústria da seca" (ibidem, p.138).

Outro fator relevante foi sua convivência intensa com a população carente em razão de seus pais terem se separado ainda na infância. Ao ter ido morar com a mãe (à época, mulher abandonada pelo marido 
não possuía direitos), não recebia ajuda financeira por parte do pai justo em uma época em que a função da mulher era ser única e exclusivamente dona de casa. "O fato de ser filho de pais separados, de ser filho único por parte mãe, e de ter tido uma infância com privações e ao lado de crianças que habitavam os mocambos erguidos nos mangues [...] marcaram muito a sua trajetória" (ibidem). Os mocambos de Recife são equivalentes às favelas do Rio de Janeiro e das grandes metrópoles, diferenciando apenas sua fundação e estrutura, mas idênticas na função: moradia de pessoas pobres. Palafitas improvisadas que margeiam os rios da capital, o Capibaribe e o Beberibe, amarradas umas às outras por tiras grossas de pano conhecidas como "mulambos", por causa da instabilidade da maré baixa.

Após ter se mudado para a cidade de Salvador (BA) para estudar medicina, tendo depois se transferido para a capital fluminense, retorna à sua cidade natal (Recife) e, com certa experiência anterior em artigos para jornais e revistas, entre 1935 e 1937, escreve narrações e contos sobre a Região Nordeste, tendo esses sido reunidos em seu primeiro livro de ficção, Documentário do Nordeste, publicado em 1937.

São contos e crônicas, quase documentários, que possuíam como tema básico o pauperismo nordestino, sendo a maioria sobre a vida nos mangues e mocambos da capital pernambucana, Tem-se a impressão de que, neste momento, ele começou a perceber melhor que sua cidade era a 'sociedade traçada no solo'. A crueza na descrição da realidade brasileira fazia parte da tendência modernista da época, de se opor ao formalismo, aos estilos rebuscados e importados. (ibidem, 140)

O livro Documentário do Nordeste serviu como matriz de seu único romance, Homens e caranguejos, publicado em 1967 no seu exílio na França. Além dos próprios capítulos do romance fazerem referência direta aos contos (como "O despertar dos mocambos" e "João Paulo"), a maior parte do prefácio de Homens e caranguejos, intitulado "Prefácio um tanto gordo para um romance um tanto magro" é de trechos reproduzidos integralmente da obra anterior. 
É uma obra nostálgica, especialmente em relação ao prefácio. São suas lembranças de criança nos manguezais de Recife que, quando adulto, estabelecem conexões mais concretas, tendo a fome como protagonista.

O tema deste livro é a história da descoberta que da fome fiz nos meus anos de infância, nos alagados da cidade de Recife, onde convivi com os afogados deste mar de miséria. Procuro mostrar neste livro de ficção que não foi na Sorbonne, nem em qualquer outra universidade sábia, que travei conhecimento com o fenômeno da fome. $\mathrm{O}$ fenômeno se revelou espontaneamente a meus olhos nos mangues do Capibaribe, nos bairros miseráveis da cidade do Recife [...]. Esta foi minha Sorbonne: a lama dos mangues de Recife... (Castro, 2007, p.10)

Essa obra dedica uma enorme atenção ao mangue, tanto do ponto de vista afetivo quanto do biológico e, especialmente, do caráter social. Considerando que o "espaço urbano é diferentemente ocupado em função das classes em que se divide a sociedade urbana" (Santos, 1987, p.83), os mangues recifenses, sob imposição do olhar excludente do capital, abrigaram ao longo do tempo uma significativa população de seres humanos expulsos pelo latifúndio e pelas secas na década de 1930 (Melo Filho, 2003, p.510).

A primeira sociedade que travei conhecimento foi a sociedade dos caranguejos. Depois, a dos homens habitantes dos mangues, irmãos de leite dos caranguejos. Só muito depois é que vim a conhecer a outra sociedade dos homens - a grande sociedade [...]. É a história da sociedade desses seres anfíbios que eu conto neste livro. Desta sociedade que, economicamente, também é anfíbia, pois vegeta nas margens ou bordas de duas estruturas econômicas que a História até hoje não costurou num mesmo tecido: a estrutura feudal e a estrutura capitalista. Estruturas que persistem no Nordeste do Brasil, lado a lado, sem se fundirem, sem se integrarem até hoje num mesmo tipo de civilização. (Castro, 2007, p.14) 
Josué de Castro assinala que há uma convivência espacial dos homens (que vivem nos mangues) com os caranguejos. Quando ele afirma que a lama dos mangues do Recife é "povoada de seres humanos feitos de carne de caranguejo", possivelmente está destacando a matéria (caranguejo) que forma o objeto (homem), empregando uma nova espécie pelo gênero: o homem-caranguejo (Melo Filho, 2003, p.513).

a lama dos mangues do Recife, fervilhando de caranguejos e povoada de seres humanos feitos de carne de caranguejo, pensando e sentindo como caranguejos. Seres anfíbios - habitantes da terra e da água, meio homens e meio bichos. Alimentados na infância com caldo de caranguejo: este leite de lama. Seres humanos que se faziam assim irmãos de leite dos caranguejos. (Castro, 2007, p.10)

Segundo Melo Filho (2003, p.513), "a partir dessas digressões semânticas ou semiológicas, pode-se concluir que durante a formação das expressões homem caranguejo ou homem-caranguejo, houve transferência de nome por semelhança de sentido, daí o aparecimento da metáfora". A seguinte passagem de Josué de Castro (2007, p.10) reforça essa relação:

Cedo me dei conta deste estranho mimetismo: os homens se assemelhando em tudo aos caranguejos. Arrastando-se, acachapando-se como os caranguejos para poderem sobreviver. Parados como os caranguejos na beira da água ou caminhando para trás como caminham os caranguejos.

Pelo uso de linguagem figurada, Josué de Castro também relaciona o meio natural com o social por meio de denúncia. Talvez em razão da época em que foi escrito o texto do prefácio, começo da ditadura militar brasileira na década de 1960 (o livro foi publicado em 1967), e de sua condição como exilado político, o homem-caranguejo é um ser predestinado à pobreza desde o seu nascimento, sem a possibili- 
dade de ascensão social, sendo supostamente o responsável por sua tragédia o "mangue":

É por isso que os habitantes dos mangues, depois de terem um dia saltado para dentro da vida, nesta lama pegajosa dos mangues, dificilmente conseguiam sair do ciclo do caranguejo, a não ser saltando para a morte [...]. A impressão que eu tinha era que os habitantes dos mangues - homens e caranguejos nascidos à beira do rio -, à medida que iam crescendo, iam cada vez atolando mais na lama. [...] E assim ficavam todos eles afogados no mangue, agarrados pelas ventosas com as quais os mangues insaciáveis lhes sugavam todo o suco de sua carne e da sua alma de escravos. (ibidem, p.11)

\section{Homem-gabiru}

Gilberto Dimenstein (1998, p.147), em seu livro O cidadão de papel, noticia em parágrafo único o extraordinário acontecimento: "No Brasil estaria surgindo uma sub-raça, formada por baixinhos. Ganharam até o nome de homens-gabirus e são do tamanho dos pigmeu da África".

Essa "sub-raça" é o resultado da falta de comida que rendeu ao trabalhador rural Amaro José da Silva, que na época tinha 47 anos, sua estatura de apenas 1,35 metros de altura. Morador do município de Engenho Bondade, Zona da Mata do Estado de Pernambuco, foi descoberto pelo jornalista cearense Xico Sá e se tornou um dos maiores furos de reportagem para o jornal A Folha de S.Paulo. No dia 19 de novembro de 1991, a manchete "Homem-gabiru é nova espécie no Nordeste" apresenta ao Brasil um semelhante cujo corpo, vitimado pela fome, pela desnutrição e pela pobreza desde seu nascimento, mais se assemelha ao de um bicho.

Na década de 1940, o também pernambucano Manuel Bandeira já denunciava o prenúncio dessa "nova espécie de homem": 
Vi ontem um bicho

Na imundície do pátio

Catando comida entre os detritos.

Quando achava alguma coisa,

Não examinava nem cheirava:

Engolia com voracidade.

O bicho não era um cão,

Não era um gato,

Não era um rato.

O bicho, meu Deus, era um homem.

(Manuel Bandeira, "O bicho", 1947)

Amaro José não é o único vitimado, pois, além de sua família, é possível encontrar pessoas rendidas tanto no interior quanto na capital do Estado - assim como em toda a Região Nordeste. Em relação ao caso particular da metrópole, mudanças ocorridas no espaço urbano, guiadas pela lógica capitalista, aterram os mangues e expulsam quem lá mora. Esse homem, que tinha sua vida ao lado e à base dos caranguejos, o homem-caranguejo, sai do mangue e vai morar em favelas e lixões, transformando-se também em homem-gabiru.

Eis a primeira leitura de Josué de Castro nesse cenário contemporâneo.

A nova metáfora homem-gabiru constitui uma hipérbole da metáfora original homem-caranguejo, pois o mangue "transbordou", "ganhou o asfalto" e, por isso, o "homem-caranguejo transmutou-se em "homem-gabiru" (Portella et al., apud Melo Filho, 2003, p.516).

O homem-caranguejo fora substituído pelo homem-gabiru, [...] porque, saindo do mangue, ele foi viver em tocas, em morros, em casebres e em velhos sobrados abandonados, fugindo ao convívio dos seus semelhantes, enxotado e detestado por ele, vendose privado de seu principal alimento (o caranguejo). O olhar que observa é de ódio e de medo, mas o medo é recíproco, o pobre, o miserável, passou a se tornar agressivo, porque sai de seu esconderijo para procurar o alimento nas ruas, nos depósitos de lixo ou 
para roubá-lo dos transeuntes menos prevenidos; tornou-se um rebotalho social, perdeu cidadania, o respeito próprio e se animalizou, sem que o poder público tivesse o menor interesse por ele. Daí o homem-gabiru que come restos-quando come-esconder-se dos outros homens e não ter alternativa no meio em que vive. (Andrade apud Melo Filho, 2003, p.516)

Gabiru é o rato de esgoto das cidades, por isso a associação aos homens-gabiru, que vivem do lixo, pedem esmolas, causam repugnância. Em relação ao posicionamento do poder público, a música Édipo, o homem que virou veículo, conta como as autoridades, perplexas com esse fenômeno social, decidem tomar as "providências cabíveis" para solucionar o problema - extinguir os sintomas e não a causa. O predicado do título dessa música, referente ao homem "que virou veículo", faz referência aos veículos de comunicação da imprensa pelo alarde criado em torno do caso de Amaro José.

"Isso é o que dá viver catando lixo

Que falta de educação, mané

Que tal criar vergonha, quem já viu ser

Transportadora de bicho de pé

Na secretaria há uma enorme preocupação

Com uma nova epidemia que ameaça a população

Pois um infeliz parece um mutante

Quando ele anda o que se vê

Segundo a secretaria faz dó

O pobre é uma malha ferroviária ambulante

Refrão

Sua excelência o prefeito homem de coração

Se declarou perplexo e horrorizado

Tanto que já mandou tomar providencias

Todo lixão será protegido por vigilantes armados

Que vão entregar cartilhas aos pés inchados".

(Fred Zeroquatro, Édipo, o homem que virou veículo, 1998) 
Sua definitiva taxonomia veio com a publicação do livro Homem Gabiru: catalogação de uma espécie (1992), dos pesquisadores do Centro Josué de Castro Tarsiana Portella, Daniel Amos e Zelito Passavante. A "nova espécie" foi catalogada, sendo descritas suas características, habitat, hábitos, alimentação, reprodução, expectativa de vida e morfologia interna, tendo como respaldo a negligência social como causadora dessa bizarra análise de um Homo sapiens sapiens.

O alívio veio quando a revista Veja, em matéria publicada no dia 23 de setembro de 1998, com a manchete "O filhão do gabiru", visitou novamente a família do homem-gabiru e desmontou a tese dessa nova raça anã do Nordeste. Em razão da melhoria do padrão de vida e do melhor acesso à comida nos últimos anos, a foto de Amaro José e seu filho Jones, de 19 anos, contrasta a diferença de estatura entre eles. Com 1,69 metro de altura, seu primogênito confirmava que essa disparidade não poderia ser explicada por doença ou anomalia genética, sendo o motivo real o nanismo nutricional causado por fome ou má alimentação durante longo período na vida de Amaro José, tendo um comido na época certa (infância e adolescência) e o outro não (Gois, 1998).

\section{Caranguejos-com-cérebro e o Manguebit}

Segundo Melo Filho (2003, 515), "a segunda releitura de Josué de Castro ocorre no âmbito do Movimento Mangue. Quase vinte anos após a morte de Josué de Castro, o mangue é novamente visitado".

Se há no mangue uma intensa atividade biológica, essa 'energia' poderia ser captada pela cidade, para 'sacudir' a mesmice na qual ela se encontrava atolada, além de proporcionar cura para seus males. Com essa preocupação, surgiu no Recife, na década de 1990, um movimento artístico-musical - o Movimento Mangue ou o Manguebeat. (ibidem) 
Uma urbe afundada por sucessivas crises econômicas, estagnação, e uma permanência do posto de "metrópole", a cidade do Recife chegou a ser considerada, nos anos 1990, a quarta pior cidade do mundo para se morar (Sharp, 2001, p.20). Com a cena cultural também deprimida, nessa mesma década, tendo como objetivo de tirar a cidade do Recife do marasmo cultural, um grupo de pessoas começou a pensar e articular uma solução baseada na ideia de produção cultural própria, inédita, tendo como referências os ritmos e símbolos da cultura pernambucana sob a óptica da estética pós-modernista. Resultado: o Manguebit.

Transitando entre as esferas local e global, o movimento Manguebit apresenta ao Brasil uma inédita cena cultural que trabalha com a interação entre a tradição e a contemporaneidade de forma conjunta, fundida, híbrida.

Da fusão de ritmos regionais (maracatu, samba, coco, ciranda) com o pop (funk, rock, soul, black, hip hop, punk), desenvolve-se essa síntese musical que expõem um tipo de sincretismo de ritmos e a interação deles com as diversas culturas do globo. $\mathrm{O}$ tambor tribal se junta à guitarra e aos amplificadores norte-americanos. A releitura de ritmos regionais, conceitos e ideias pop não se manifesta de forma passiva. A tentativa de universalizar esses elementos nacionais, com o intuito de mostrar e criar uma nova cena para o mundo, conectando o Brasil com o cenário pop mundial, estabelece um diálogo com as manifestações artísticas que trouxeram à tona um Brasil cosmopolita como o Movimento Antropofágico e a Tropicália. (Leão, 2002, p.8-9)

Os integrantes das bandas Chico Science e Nação Zumbi e Mundo Livre S/A foram os responsáveis pela criação do movimento Manguebit, sendo Chico Science e Fred Zeroquatro as duas figuras centralizadoras dessa cena Mangue. Science faleceu precocemente em um acidente de carro no trajeto entre as cidades de Recife e Olinda em 2 de fevereiro de 1997, tendo recebido em seu funeral uma grande homenagem da nação Maracatu Piaba de Ouro, do lendário 
mestre Salustiano, com a presença de seis mil pessoas. Miguel Arraes, governador do Estado de Pernambuco na época, decretou luto oficial de três dias.

O Manguebit é algo essencialmente ligado à cultura pop. Originalmente, o termo e o estilo surgiram das experiências da Pop Art, reveladas na década de 1940 por seu vanguardista mais conhecido, Andy Warhol. Preocupada em apresentar o cotidiano no mundo contemporâneo, a cultura pop e suas definições integram o que se convenciona chamar de pós-modernismo (ibidem, p.1).

O neologismo Manguebit é a tentativa de fusão entre duas palavras de sentido e origem opostas: "Mangue", ecossistema de estuários e "Bit", a menor extensão de memória de computadores. Pela possibilidade da sinergia global e local, o próprio nome Manguebit se refere à tentativa de comunicação entre os manguezais recifenses com o fluxo de informações mundiais, sendo a sintética imagem de uma antena parabólica incrustada na lama do mangue o símbolo do movimento (Picchi, 2009, p.3).

Essa nova expressão cultural, que busca elementos contemporâneos, como globalização, identidades culturais, intertextualidade, desconstrução, hibridez, pluralismo, pode ser observada numa escala global de acontecimentos.

Em metrópoles foram sendo geradas novas formas de comunicação que traziam elementos da cultura popular $(f o l k)$ misturadas a outras informações obtidas via meios de comunicação. É o caso do grupo Mano Negra em Paris, Massive Attack em Bristol, Chico Science e Nação Zumbi e Mundo Livre S/A no Recife. (Leão, 2002, p.4).

O pós-modernismo na cultura dos anos 90 , no Recife, ou o experimentalismo pop, ficou marcado por Francisco França, o Chico Science, garoto do subúrbio, músico de rua, articulador do movimento chamado Manguebit, que propôs descaradamente o exercício da ironia, numa inquieta busca de uma "Consciência Transcendental", fazendo o Brasil e o mundo viajarem num pro- 
duto conceitual, destruindo o projeto romântico e impulsionando a contracultura - a cultura alternativa. (Neto, 2001, p.31-2)

Em 1992, Fred Zeroquatro e Renato Lins, na época jornalistas do Diário do Commércio de Recife, redigem um documento que procura sintetizar as ideias dessa nova geração de artistas. Intitulado de "Caranguejos-com-cérebro", o press release logo se transformou em "manifesto", por meio da crítica musical, especialmente a do Jornal do Commércio (JC) de Pernambuco, e chegou aos jornalistas causando grande euforia na imprensa pernambucana (Leão, 2002, p.9).

O documento se divide em três partes: Mangue - o conceito, sendo uma pequena lição científica sobre o ecossistema do mangue; Manguetown - A cidade, aspectos da geografia da cidade do Recife, construída sobre a lama dos manguezais, sendo também uma crítica ao sistema econômico capitalista; e Mangue - a cena, terceira e última parte, que em tom de urgência, explicita os objetivos e metas do movimento para que Recife, segundo suas palavras, "não morra de infarto".

O "Caranguejos-com-cérebro" toma o ecossistema da cidade como metáfora e subverte os seus princípios ecológicos ao desgaste físico e cultural da metrópole recifense (ibidem, p.9-10). Esse desgaste físico e cultural é o principal desafio para a imaginação e produção Manguebit, tendo uma antena parabólica enfiada na lama dos manguezais como imagem símbolo, capaz de captar os conceitos pop, o que seria capaz de tirar Recife da situação de inércia (Morais de Souza, 2001, p.4).

Foi por causa do formato desse press release lançado na mídia que as músicas e ideias do Manguebit assumiram um caráter de "movimento", como um resgate do Movimento Modernista de 1922 e seu Manifesto Pau-Brasil de Oswald de Andrade. Outro fator foi a metáfora criada para o título de "Caranguejos-com-cérebro", sendo essa a alcunha da segunda leitura do conceito de homem-caranguejo proposta por Melo Filho (2003).

A influência das obras de Josué de Castro é de grande importância no movimento Manguebit, partindo desde o título de seu ma- 
nifesto até evocações a Josué nas letras musicais. No documentário Manguebeat: uma evolução (2007), Dengue, baixista da banda Nação Zumbi e um dos integrantes do núcleo base do movimento, relata a influência da obra de Josué de Castro na construção do caráter da cena Mangue:

Teve o lance de Chico (Science), em relação ao mangue. Ele leu de Josué de Castro Geografia da Fome, e, quando leu esse livro ele pirou, porque foi daí que ele tirou que Recife era mangue, e o ciclo do caranguejo, e foi daí que veio toda a ideia da metáfora Mangue. Ele percebeu que um cara há 40,50 anos atrás estava falando de um negócio que é a cara da cidade e que ninguém tinha percebido muito. Enquanto o cara tinha ido morar na França, aqui em Recife a galera não sabia quem era Josué de Castro e que o cara já falava inclusive coisas pertinentes quanto à condição econômica da cidade, e de na época (do início do movimento Manguebit, na década de 1990) ser a quarta pior do mundo em termos estatísticos. (Manguebeat: uma evolução, 2007)

O Manguebit modificou o que era conhecido por cultura brasileira nos anos 1990 de forma radicalmente inovadora, porém, calcada nas referências nacionais como provedoras da inovação. A revista especializada em música Rolling Stone considerou Chico Science um dos dez maiores músicos da história da música brasileira. Com o título "De Recife para o Brasil, ele olhava para o futuro", o jornalista Mateus Potumati escreveu:

Em 1994, regionalismo e música pop andavam brigados. Então, Chico Science e sua Nação Zumbi lançaram Da Lama ao Caos. Inspirado no cânone da tropicália, o disco-manifesto sacudiu o consenso roqueiro ao reavivar o maracatu e a embolada sob verniz do funk-metal e do hip-hop. Bem articulado na imprensa, em dois anos o manguebit estourou, e a via aberta por Chico deu passagem de Mundo Livre S/A a Mombojó. Para ele, bastou ter Recife sob os pés e a mente na imensidão. (Rolling Stone, 2008, p.133) 
CaetanoVeloso (1997, p.240), em seu livro Verdade tropical, tece considerações acerca de Chico Science, sobre a ideia de "modernizar o passado" ser uma "evolução musical", em razão do resgate realizado por Science em busca de uma nova leitura da identidade brasileira:

Saúdo a chegada de Chico Science contra a crítica que se submete (explicitamente!) ao número de cópias vendidas de um CD ou à intensidade e duração dos aplausos em salas de espetáculo. [...] Sem falar no fato de que ele, em seu resgate do barroco e sua redescoberta de figuras mais ambiciosas e inventivas do que a história da literatura brasileira, enfatizara, como disse o historiador norteamericano Richard M. Morse, "uma nova leitura da genealógica de troncos, galhos e rebentos que apontam para uma formação gradual de 'identidades' transatlânticas". É a força da visão sincrônica. E a superação da oposição centro-periferia.

\section{Considerações finais}

O pensamento de Josué de Castro, especialmente em razão da temática da fome, é tão presente que se torna possível a proposição analítica de uma evolução. Evolução do fenômeno da fome ou uma real involução social?

Do homem-caranguejo de ontem ao homem-gabiru de hoje, é a pura reprodução do caos social que firma-se ao longo destas quatro décadas com o constante espectro da fome. Porém, esse sintético caranguejo globalizado, o caranguejo-com-cérebro, que surge com a proposição de subverter os manguezais de Recife e conectá-los com os fluxos globais gerados por um admirável mundo novo wi-fi, propõe usufruir de todo o ensinamento da severina vida do homem-caranguejo para fazer algo novo. É a rebelião 2.0 dos mocambos de Recife.

Se anteriormente Josué de Castro foi responsável por universalizar a fome, o movimento Manguebit também buscou uma universalização, a de sua cultura, tendo Pernambuco embaixo dos pés e a mente na imensidão. 


\section{Referências}

AMANCIO ALVES, J. J. Uma leitura geográfica da fome com Josué de Castro. Rev. Geogr. Norte Gd., Santiago, n.38, dez. 2007. Disponível em: <http://www.scielo.cl/scielo.php?script=sci_arttext\&pid=S0718$34022007000200001 \& \operatorname{lng}=e s \& n r m=i s o>$. Acesso em: 3 dez. 2009.

BANDEIRA, M. Estrela da vida inteira. Rio de Janeiro: Nova Fronteira, 1993.

CAMPOS, R. R. de. A dimensão populacional na obra de Josué de Castro. Tese (Doutorado em Geografia) - Instituto de Geociências e Ciências Exatas, Universidade Estadual Paulista "Júlio de Mesquita Filho". Rio Claro, 2004.

CASTRO, J. de. A alimentação brasileira à luz da geografia humana. Porto Alegre: Livraria da Globo, 1937.

Homens e caranguejos. Rio de Janeiro: Civilização Brasileira, 2007.

DIMENSTEIN, G. O cidadão de papel - a infância, a adolescência e os direitos humanos no Brasil. São Paulo: Ática, 1998.

GOIS, A. O filhão do gabiru. Revista Veja. 1998. População. Disponível em: <http://veja.abril.com.br/230998/p_104.html>. Acesso em: 6 ago. 2009.

LEÃO, C. C. A maravilha mutante - batuque, sampler e pop no recife dos anos 90. Dissertação (Mestrado em Comunicação) - Pós-Graduação em Comunicação, Universidade Federal de Pernambuco. Disponível em: <http://salu.cesar.org.br/mabuse/servlet/newstorm.notitia. apresentacao.ServletDeSecao?codigoDaSecao=647\&dataDoJornal $=$ at ual>. Acesso em: 6 ago. 2007. Recife, 2002.

MANGUEBEAT, Uma evolução. Direção, roteiro e imagens: Eduardo Dui e Paulo Daniel Câmara. Edição: Paulo Daniel. Recife: s/ produtora. 1 DVD (25 min), son., color, 2007.

MARCHI, D. D. O pensamento geográfico de Josué de Castro nas décadas de 40 e 50: a fome e a produção de alimentos. Trabalho de Conclusão de Curso (bacharel em Geografia) - Instituto de Geociências e Ciências Exatas, Universidade Estadual Paulista "Júlio de Mesquita Filho". Rio Claro, 1998.

MELO FILHO, D. A. de. Mangue, homens e caranguejos em Josué de Castro: significados e ressonâncias. História, Ciências, Saúde - Manguinhos, Rio de Janeiro, v.10, n.2, maio-ago. 2003.

MORAIS DE SOUZA, C. (2001). "Da lama ao caos": diversidade, diferença e identidade cultural na cena mangue do Recife. Informe final 
del concurso: Culturas e identidades en América Latina y el Caribe. Universidade Federal de Pernambuco. Programa Regional de Becas Clacso. Recife, 2001.

NETO, M. Chico Science: a rapsódia afrociberdélica. Recife: Edições Ilusionistas, 2001.

PICCHI, B. Diálogo local e global no Nordeste contemporâneo: o caso do movimento manguebit de Recife (PE, Brasil). In: ENCUENTRO DE GEÓGRAFOS DE AMÉRICA LATINA, 12, Montevideo, 2009. Disponível em: <http://egal2009.easyplanners.info/area01/1180_Picchi_Bruno.rtf>. Acesso em: 30 jul. 2009.

ROLLING STONES. Os cem maiores músicos da história brasileira. São Paulo, ano 2, n.25, 2008

SHARP, D. B. A satellite dish in the shantytown swamps: musical hybridity in the 'new scene' of Recife, Pernambuco, Brazil. Dissertação (Mestrado em Artes) - Faculty of the Graduate School, The University of Texas at Austin. Austin, 2001. Disponível em: <http://salu.cesar.org.br/ mabuse/servlet/newstorm.notitia.apresentacao.ServletDeSecao?cod igoDaSecao=647\&dataDoJornal=atual $>$. Acesso em: 22 ago. 2007.

VELOSO, C. Verdade tropical. São Paulo: Cia. das Letras, 1997. 


\section{3 \\ A TEORIA GEOGRÁFICA \\ NOS ESTUDOS DO TURISMO: ELEMENTOS TEÓRICO-METODOLÓGICOS}

Elias Júnior Câmara Gomes Sales*

\section{Introdução}

O estudo da ciência geográfica envolve uma diversidade de temas que contemplam a relação sociedade-natureza, foco dessa ciência. A proximidade com outras ciências (naturais, sociais e humanas) confere à geografia um caráter distinto na sua configuração epistemológica, ou seja, o diálogo com outras áreas do conhecimento sempre esteve presente nos debates e construções das categorias analíticas de estudo, conceitos-chave, metodologias de pesquisa, teorias e aplicações.

Desde sua fundação como ciência moderna, no início do século XIX, aproximando-se das ciências naturais com Alexander von Humboldt e Karl Ritter, passando pelas ciências sociais e humanas, nos estudos culturais, econômicos do espaço geográfico, a geografia esteve associada a outras ciências. Essa trama de questões que conjugam o espaço geográfico (categoria de análise da geografia) nos remete a procurar em outras ciências fundamentos e metodologias que auxiliem na construção epistemológica da geografia,

* Mestrando em Geografia e membro do Núcleo de Estudos Agrários da Unesp - Rio Claro (SP). Bolsista CNPq. 
mas ao mesmo tempo, contribuir para a construção e transformação de outras ciências que se aproximam em assuntos teóricos e práticos.

Dessa maneira, o turismo, ao estudar as formas, organização e impactos dessa atividade no contexto social, ambiental e econômico, remete à geografia algumas noções e estratégias no uso do território, utilização da paisagem, além de questões relativas às políticas públicas e privadas do turismo e o espaço.

Assim, pretende-se neste breve debate discutir algumas teorias e conceitos pertinentes à geografia, que estão sendo trabalhadas na geografia do turismo, além de discorrer acerca de temas do turismo e a aplicação dessas teorias e conceitos geográficos, destacando a interconexão dessas áreas do conhecimento e promovendo a interdisciplinaridade tão enfatizada no mundo acadêmico-científico.

\section{Teorias e conceitos na geografia do turismo}

Serão tratados neste trabalho algumas conceitos e teorias na geografia que servem de suporte nos estudos do turismo, definindo-os e expondo suas características e aplicações. Os conceitos de Paisagem e Território são categorias analíticas pertinentes em diversas temáticas da geografia do turismo, pois contemplam questões referentes as elementos naturais e artificializados (Paisagem), como questões que envolvem aspectos culturais, políticos, econômicos e ambientais (Território). Dessa maneira, discutir-se-ão as abordagens teóricas e práticas desses conceitos na geografia, para em seguida fazer a interconexão com o turismo, além de elencar e debater teorias que tratam do espaço geográfico e seu uso nos estudos do turismo.

A geografia caracteriza-se pelo estudo da relação sociedade - natureza ou homem-meio, sendo esse o objeto de estudo dessa ciência. A forma como essa ideia/pensamento é colocada na teoria é definida pela categoria "espaço geográfico", ou seja, a referência teórica da geografia está associada ao espaço e suas dinâmicas, relações e processos entre a sociedade e a natureza (Esquema 1). 


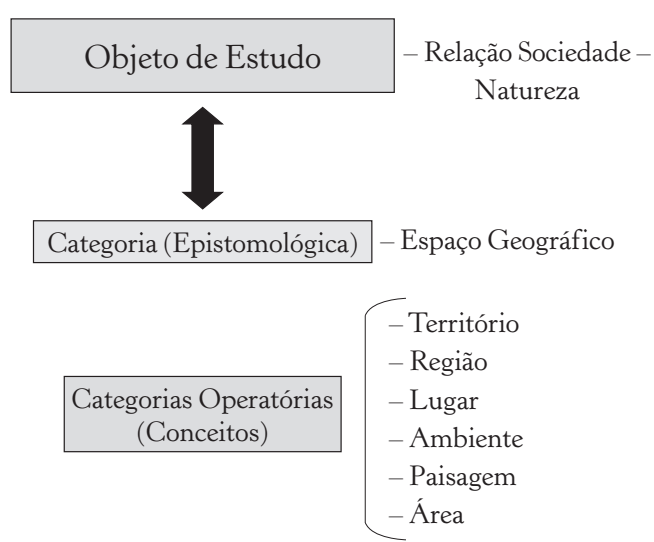

Esquema 1 - Objeto de estudo, categorias e conceitos geográficos (Organizado pelo autor)

O turismo como atividade dinâmica representa um agente que interfere na construção do espaço geográfico, estando ligado com o objeto de estudo da geografia (relação sociedade-natureza), além de estar intrinsecamente conectado à categoria espaço geográfico, pois alguns elementos conceituais como a paisagem, território e lugar são usados como produtos ou atrativos para a realização da atividade turística.

A teoria geográfica concede às outras ciências uma gama de possibilidades para discutir as relações e processos que envolvem agentes e atores transformadores do espaço geográfico. Conforme aponta Rejowski (2001, p.18), o turismo apresenta múltiplas concepções temáticas, que o envolve numa trama de conhecimentos de diversas ciências: "Por ser um fenômeno de múltiplas facetas, penetra em muitos aspectos da vida humana, quer de forma direta, quer indireta. Consequentemente, tem-se desenvolvido utilizando métodos e técnicas de várias disciplinas".

Assim, o turismo representa um elo entre diversas ciências, entre essas conexões está a geografia, que tem uma história epistemológica conflitante, por estar entre as ciências naturais, humanas e sociais. Esse conflito epistemológico, que define sua base teórico- 
metodológica, é pertinente no turismo, pois possibilita uma discussão profunda na construção do seu referencial, categorias de análises, objeto de estudo, conceitos-chave, técnicas de pesquisa entre outros fundamentos.

A geografia e o turismo caminham em perspectivas teóricas semelhantes no que se refere a alguns marcos conceituais, mas estabelecendo suas peculiaridades e objetivos distintos. Segundo Rejowski (2001, p.19), essas duas disciplinas concentram ideias e áreas em comum: "Geografia: é uma das poucas disciplinas em que o turismo tem sido reconhecido como área de interesse e, como tal, vem sendo estudado sob a denominação de geografia do turismo, geografia turística, geografia da recreação ou geografia recreacional".

Dessa forma, serão analisados alguns conceitos com base na ciência geográfica, esclarecendo sua definição e conjectura, para que, consequentemente, seja utilizado e aplicado nas pesquisas da geografia do turismo

\section{Paisagem na geografia do turismo}

A paisagem, um dos conceitos fundantes da ciência geográfica, foi utilizada no século XIX, inicialmente, por Alexander von Humbol$\mathrm{dt}$, para caracterizar os quadros naturais do espaço geográfico. Esse conceito esteve por muito tempo associado, somente, aos aspectos naturais e físicos, mas com os trabalhos de Paul Vidal de La Blache, no início do século XX, acrescentou-se o elemento cultural/humano na paisagem. A partir da metade do século XXI, o conceito de paisagem transformou-se para paisagem natural e paisagem artificial, dando caracteres aos elementos construídos e modificados pela ação antrópica.

A respeito desta última classificação de paisagem, Santos (2006, p.103), define da seguinte maneira:

A paisagem é um conjunto de formas que, num dado momento, exprimem as heranças que representam as sucessivas relações loca- 
lizadas entre homem e natureza. [...] a paisagem é apenas a porção da configuração territorial que é possível abarcar com a visão [...] a paisagem se dá como um conjunto de objetos reais-concretos.

Assim, com essa definição de paisagem na geografia, o turismo pode empreender aquilo que representa atrativos naturais ou artificiais para o desenvolvimento da atividade turística, como locus central de diversos tipos de turismo, seja o turismo rural, de aventura, litorâneo, entre outros que exploram os recursos físicos do espaço geográfico.

Dessa forma, é possível debater a necessidade da criação de conceitos operacionais para as teorias do turismo, e a paisagem (natural e artificial) representa um conceito-chave para tal construção teórica.

\section{Identidade e patrimônio do conceito de território}

A classificação de áreas agrupadas em territórios corresponde numa identidade própria do local, essa definição pode levar em consideração aspectos simbólicos, políticos, econômicos, culturais ou ambientais do território. Na geografia, o território é definido por esses aspectos, e sua preservação pode trazer benefícios aos grupos sociais pertencentes a esse território.

Souza (2003, p.84) define o território levando em consideração a identidade e os atributos socioculturais:

A ocupação do território é vista como algo gerador de raízes e identidade: um grupo não pode ser mais compreendido sem o seu território, no sentido em que a identidade sociocultural das pessoas estaria inarredavelmente ligada aos atributos do espaço concreto (natureza, patrimônio, "paisagem"). E mais: os limites do território não seriam, é bem verdade, imutáveis [...] mas cada espaço seria, enquanto território, território durante todo o tempo, pois apenas a durabilidade poderia, é claro, ser geradora de identidade socioespacial, identidade na verdade não apenas com o espaço físico, con- 
creto, mas com o território e, por tabela, como o poder controlador desse território.

A valorização e preservação de áreas com características intrínsecas são amplamente estudadas pelo turismo. $\mathrm{O}$ empreendimento de territórios para a prática turística ganha, cada vez mais, força e público para essa atividade. Além de contribuir economicamente para as populações locais, pode estimular a manutenção de aspectos culturais e preservação de raízes e costumes do local.

Essa relação entre manutenção da identidade do território e prática do turismo pode levar a um ajustamento do território para o turismo, conforme lembra Cruz (2001, p.21) "Para que o turismo possa acontecer, os territórios vão se ajustando as necessidades trazidas por essa prática social. Novos objetos e novas ações; objetos antigos e novas ações: essa é a lógica da organização socioespacial promovida pela prática do turismo".

Assim como a paisagem, o território é outro conceito-chave que deve ser amplamente utilizado nas pesquisas em turismo, por tratar de questões referentes aos aspectos que enfatizam uma determinada localidade, especialmente no que tange a cultura e o patrimônio histórico.

\section{A abordagem sistêmica como metodologia no estudo da geografia do turismo}

Considerando o estudo da geografia do turismo como uma abordagem interdisciplinar, enfocaremos uma metodologia que possa fazer a ligação entre teoria e prática entre duas áreas do conhecimento, analisando as bases teóricas de cada área, além de fazer a relação entre os objetos de estudo e as congruências epistemológicas. Nesse sentido, adotaremos a abordagem sistêmica como uma metodologia para o estudo da geografia do turismo.

Para que haja a interdisciplinaridade, requer-se um arranjo metodológico pertinente que possa conduzir uma pesquisa entre várias 
áreas do conhecimento, Rejowski (2001, p.49) discorre sobre essas questões:

O pesquisador precisa saber da existência de outros recursos metodológicos além daqueles de sua área acadêmica específica, os quais podem se revelar mais adequados ao estudo do tratamento de determinado tema em turismo. Daí a necessidade de um quadro referencial metodológico da pesquisa em turismo, para o desenvolvimento de trabalhos interdisciplinares.

A complementaridade entre as ciências e o turismo enriquece cada vez mais o discurso teórico-metodológico para essa área do conhecimento. Tendo em vista a conexão com outras ciências:

cada vez mais o estudo do turismo vem despertando o interesse de várias áreas do conhecimento no meio acadêmico: de algumas poucas disciplinas para outras das ciências humanas e sociais; destas para disciplinas das ciências exatas e naturais. Isto sugere que sua compreensão requer o envolvimento de um sem-número de disciplinas. (ibidem, p.20)

Dessa forma, a abordagem sistêmica como enfoque metodológico desenvolve inúmeras relações entre o objeto de estudo das ciências e as categorias e conceitos que podem ser analisados conjuntamente.

O paradigma sistêmico na Geografia insere-se na própria necessidade de reflexão sobre a apreensão analítica do complexo ambiental, através da evolução e interação de seus componentes socioeconômicos e naturais no conjunto de sua organização espaçotemporal, sendo neste contexto que surgem as propostas de cunho sistêmico e sua fundamentação integrada da abordagem do objeto de estudo, e do entendimento do todo (sistema) e de sua inerente complexidade. (Vicente \& Perez Filho, 2003, p.334-5)

No turismo, Beni (1988) desenvolveu uma metodologia com base no enfoque sistêmico, considerando as relações entre os atores 
e agentes que compõem o Sistema do Turismo. Esse tipo de abordagem sugere uma gama de elementos que podem ser analisados e inter-relacionados, dessa forma, sendo uma ferramenta metódica que dá sustentação as pesquisas do turismo:

Turismo constitui-se como um sistema aberto, que influencia os locais onde se desenvolve, ao mesmo tempo que é influenciado por elementos endógenos e exógenos a ele, sendo que as relações e os processos decorrentes disso são, muitas vezes, mais importantes que o fenômeno em si. (Silva, 2006, p.41-2)

No trabalho de Rejowski (2001, p.45), a autora reforça o uso da metodologia sistêmica nos estudos do turismo, para isso coloca o pensamento de Kaspar:

Visão sistêmica: emerge em função das limitações das aproximações reducionistas e holística; segundo esta visão, a análise do turismo como um sistema permite observar peculiaridades do todo e, ao mesmo tempo, propriedades específicas das partes que compõem esse todo.

Na geografia, esse pensamento metodológico remonta à década de 1960 e 1970 no Brasil, com a utilização de modelos e teorias sistêmicas, que envolvem diversos elementos que compõem a relação sociedade e natureza, objeto de estudo da ciência geográfica.

Na Geografia o uso de tal concepção é conhecido, no Brasil, deste a década de 1970 e as contribuições da academia têm ajudado na compreensão da questão ambiental que, inclui, fundamentalmente, a discussão e a análise da sociedade e de sua relação com a natureza. Ao utilizarem a teoria sistêmica, os trabalhos produzidos com esse cunho metodológico têm possibilitado o desenvolvimento de um paradigma de análise particular e muito próximo dos ideais da ciência. (Silva, 2006, p.51)

Estas breves reflexões acerca da metodologia sistêmica no turismo e na geografia servem para fundamentar e consolidar a utilização 
dessa abordagem no estudo da geografia do turismo. Existem outras forma metodológicas que podem servir de base nas pesquisas da geografia do turismo, como a dialética, estruturalismo, funcionalismo entre outros.

\section{Complementaridade das áreas do conhecimento: a interface entre turismo e geografia na universidade}

Visto os marcos teórico-conceituais que são complementares no estudo de geografia e turismo, a interdisciplinaridade entre as áreas também está atrelada aos grupos de pesquisa, cursos de graduação, pós-graduação e eventos científicos. A presença de disciplinas na geografia que tratam dos fenômenos do turismo e sua ligação com o espaço geográfico estão cada vez mais presentes, tanto em cursos de graduação como em de pós-graduação.

Os eventos científicos na geografia estão contando, atualmente, com um número expressivo de trabalhos relacionados com o turismo. Quatro eventos científicos da geografia, só para citar alguns, abordaram o turismo em eixos-temáticos específicos para esta temática (Quadro 1).

Dentre os trabalhos apresentados nos eventos científicos da geografia, a temática tratada se refere às seguintes áreas: turismo rural, turismo litorâneo, turismo urbano, turismo pedagógico e turismo cultural. A abordagem espacial focando nas relações e processos sociais é destacada nesses trabalhos, mas interligadas com a interdisciplinaridade com o turismo.

Outro aspecto que revela a complementaridade dessas duas áreas do conhecimento está nos grupos de pesquisa cadastrados no CNPq. Em 2010, segundo o Diretório de Grupos de Pesquisa do CNPq, existem 37 grupos de pesquisa relacionados com a temática da geografia no turismo ou do turismo na geografia ou geografia do turismo (Organograma 1). 
Quadro 1 -Eixos ou sessões temáticas do turismo em eventos científicos na geografia (2008 e 2009)

\begin{tabular}{|l|c|l|c|l|}
\hline \multicolumn{1}{|c|}{ Evento científico } & Ano & Local & $\begin{array}{c}\text { Número } \\
\text { de eixos } \\
\text { sessões }\end{array}$ & $\begin{array}{c}\text { Nome do } \\
\text { eixo }\end{array}$ \\
\hline $\begin{array}{l}\text { VIII Encontro Nacional } \\
\text { da Associação de } \\
\text { Pesquisa e Pós- } \\
\text { Graduação em } \\
\text { Geografia (Anpege) }\end{array}$ & 2009 & Curitiba-PR & 22 & $\begin{array}{l}\text { Geografia do } \\
\text { Turismo }\end{array}$ \\
\hline $\begin{array}{l}12^{\circ} \text { Encontro de } \\
\text { Geógrafos da América } \\
\text { Latina (Egal) }\end{array}$ & 2009 & $\begin{array}{l}\text { Montevidéu- } \\
\text { Uruguai }\end{array}$ & 39 & $\begin{array}{l}\text { Teoria e } \\
\text { prática } \\
\text { dos fluxos } \\
\text { turísticos e } \\
\text { recreativos. }\end{array}$ \\
\hline $\begin{array}{l}\text { XIX Encontro Nacional } \\
\text { de Geografia Agrária } \\
\text { (Enga) }\end{array}$ & 2009 & São Paulo-SP & 41 & $\begin{array}{l}\text { Atividade } \\
\text { turística } \\
\text { no campo } \\
\text { brasileiro }\end{array}$ \\
\hline $\begin{array}{l}1^{\circ} \text { Simpósio de } \\
\text { Pós-Graduação em } \\
\text { Geografia do Estado de } \\
\text { São Paulo }\end{array}$ & 2008 & Rio Claro-SP & 15 & $\begin{array}{l}\text { Dinâmicas } \\
\text { territoriais e } \\
\text { planejamento } \\
\text {-Turismo }\end{array}$ \\
\hline
\end{tabular}

(Organizado pelo autor)

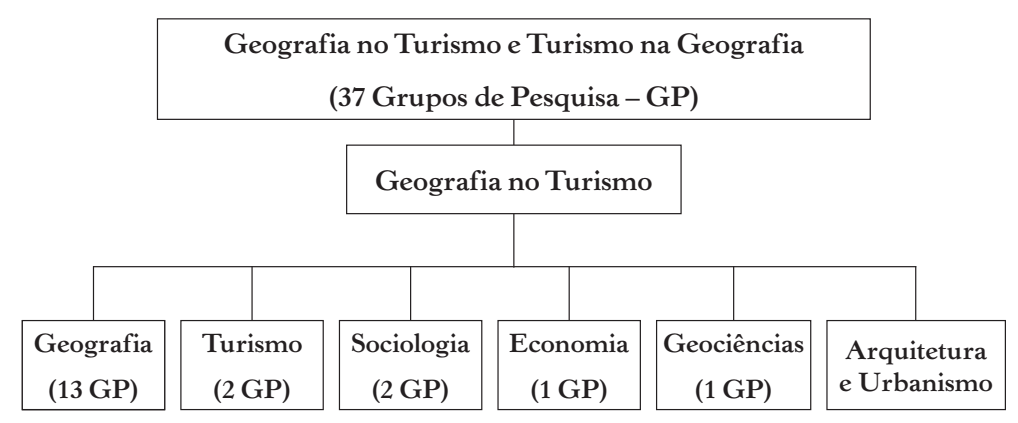

Organograma 1 - Geografia do turismo nos grupos de pesquisa nas diferentes áreas do conhecimento.

Fonte: Diretório dos Grupos de Pesquisa do CNPq. $<$ http://dgp.cnpq.br/buscaoperacional $>$ (Organizado pelo autor). 
Já com a denominação exata "Geografia do Turismo" existem 21 grupos de pesquisa que têm uma linha de pesquisa específica com esse tema; desses grupos, quatorze são de cursos de graduação ou pós-graduação em geografia, dois de turismo, dois de Sociologia, um de economia, um de geociências e um de arquitetura e urbanismo.

Numa pesquisa utilizando a expressão "Turismo Rural", resultaram quarenta grupos de pesquisas que trabalham com essa temática, dos quais dez grupos estão na área de geografia e dez na área de turismo, a outra metade está difusa entre antropologia, economia, planejamento urbano e regional, agronomia, engenharia agrícola, comunicação, geociências, ciência política, museologia e recursos pesqueiros e engenharia de pesca.

Essas breves consultas a eventos científicos e grupos de pesquisa revelam a forte ligação entre turismo e geografia, que vem crescendo no mundo universitário, pois a divisão entre as áreas do conhecimento repele um maior entendimento dos fenômenos humanos e naturais. O estreitamento entre as ciências reforça a base teórica de cada disciplina, complementando com os atributos teórico-metodológicos das outras ciências. Entretanto, deve ficar claro, que para que haja tal interdisciplinaridade é preciso que cada ciência tenha em evidência seus marcos teóricos, conceituais e metodológicos, para que possa auxiliar na evolução epistemológica.

\section{Considerações finais}

O estudo da geografia do turismo apresenta diversas formas de abordagens teórico-metodológicas que devem ser mais discutidas e aprofundadas, com intuito de fortalecer essas bases para a consolidação desse ramo interdisciplinar. A utilização dos conceitos Paisagem e Território são apenas algumas categorias que estão sendo trabalhadas na geografia do turismo; entretanto, outras concepções teóricas que são pesquisadas devem resultar em trabalhos práticos e teóricos, a fim de vislumbrar um rol de teorias e conceitos que auxiliem nos trabalhos empíricos. 
A utilização da metodologia sistêmica no estudo do turismo está se consolidando, cada vez mais, e, por isso, elencar os elementos e variáveis que devem ser pesquisadas na geografia do turismo é pertinente para que o turismo consolide métodos de pesquisa, aliados a teorias e conceitos. Essas premissas são fundamentais para que qualquer ciência possa aliar o abstrato ao empírico (concreto).

\section{Referências}

BENI, M. C. Sistema de turismo: construção de um modelo teórico referencial para aplicação na pesquisa em turismo. Tese (Doutorado em Ciências da Comunicação) - Escola de Comunicação e Artes, Universidade de São Paulo. São Paulo, 1988.

CONSELHO NACIONAL DE DESENVOLVIMENTO Científico e Tecnológico-CNPq. Diretório de Grupos de Pesquisa. Disponível em: <http://dgp.cnpq.br/buscaoperacional>. Acesso em: 15 maio 2010.

CRUZ, R. C. A. Introdução à geografia do turismo. 2.ed. São Paulo: Roca, 2003.

CUNHA, L. Introdução ao turismo. Lisboa: Editorial Verbo, 2001.

GALVÃO FILHO, C. E. P.; CALVENTE, M. C. M. H. A geografia brasileira e os estudos relacionados ao turismo: uma análise dos trabalhos de dois eventos nacionais (2002 e 2004). Geografia, Londrina, v.15, n.1, p.221-42, 2006.

GEIGER, P. P. Turismo e espacialidade. In: RODRIGUES, A. B. (Org.) Turismo e geografia: reflexões teóricas e enfoques regionais. São Paulo: Hucitec, 1996.

GONÇALVES, F. R.; GROSSI, S. R. D. Geografia e turismo: um caminhar circunstancial. In: II SIMPÓSIO REGIONAL DE GEOGRAFIA. Anais... Uberlândia, 2003, p.1-8.

REJOWSKI, M. Turismo e pesquisa científica: Pensamento internacional x Situação brasileira. 5.ed. Campinas: Papirus, 2001.

SANTOS, M. A natureza do espaço: técnica e tempo; razão e emoção. 4.ed. São Paulo: Edusp, 2006.

SILVA, C. A. Análise sistêmica, turismo de natureza e planejamento ambiental de Brotas: proposta metodológica. Tese (Doutorado em Geografia) - Instituto de Geociências, Universidade Estadual de Campinas. Campinas, 2006. 
SOUZA, M. J. L. O território: sobre espaço e poder, autonomia e desenvolvimento. In: CASTRO, I. E. et al. (Org.) Geografia: conceitos e temas. 6.ed. Rio de Janeiro: Bertrand Brasil, 2003, p.77-116.

VICENTE, L. E.; PEREZ FILHO, A. Abordagem sistêmica e Geografia. Geografia, Rio Claro, v.28, n.3, p.323-44, 2003. 
SOBRE O LIVRO

Formato: $14 \times 21 \mathrm{~cm}$

Mancha: 23,7 $\times 42,5$ paicas

Tipologia: Horley Old Style 10,5/14

$1^{\text {a }}$ edição: 2010

\section{EQUIPE DE REALIZAÇÃO}

Coordenação Geral

Marcos Keith Takahashi 

